\title{
Áreas contaminadas e a construção da paisagem pós-industrial na cidade de São Paulo
}

\author{
Tese apresentada à Faculdade de \\ Arquitetura e Urbanismo da Universidade \\ de São Paulo, para obtenção do título de \\ Doutor em Arquitetura e Urbanismo
}

Área de Concentração: Paisagem e Ambiente

Orientador: Prof. Dr. Paulo Renato Mesquita Pellegrino

EXEMPLAR REVISADO E ALTERADO EM RELAÇÃO À VERSÃO ORIGINAL, SOB RESPONSABILIDADE DO AUTOR E ANUÊNCIA DO ORIENTADOR. $O$ original se encontra disponível na sede do programa

São Paulo 25 de junho de 2013.

São Paulo 
AUTORIZO A REPRODUÇÃO E DIVULGAÇÃO TOTAL OU PARCIAL DESTE TRABALHO, POR QUALQUER MEIO CONVENCIONAL OU ELETRÔNICO, PARA FINS DE ESTUDO E PESQUISA, DESDE QUE CITADA A FONTE.

E-MAIL AUTOR: cmorinaga@uol.com.br

Morinaga, Carlos Minoru

M858a Áreas contaminadas e a construção da paisagem pós-industrial na cidade de São Paulo / Carlos Minoru Morinaga. - São Paulo, 2013. 201 p. : il.

Tese (Doutorado - Área de Concentração: Paisagem e Ambiente) FAUUSP.

Orientador: Paulo Renato Mesquita Pellegrino

1.Paisagem urbana - São Paulo (SP) 2.Contaminação (Remediação) - São Paulo (SP) 3.Poluição do solo - São Paulo (SP) 4.Reabilitação de áreas degradadas - São Paulo (SP) 5.Áreas contaminadas - São Paulo (SP) I.Título 
"A cidade de São Paulo é um palimpsesto - um imenso pergaminho cuja escrita é raspada de tempos em tempos, para receber outra nova, de qualidade literária inferior, no geral."

Benedito Lima de Toledo 


\section{Agradecimentos}

Meus profundos agradecimentos a todos os que colaboraram, de algum modo, para a conclusão desta tese, na esperança que ela possa contribuir para a discussão da construção de uma cidade melhor e mais justa.

Ao Prof. Dr. Paulo Renato Mesquita Pellegrino, pela longa e dedicada orientação que se iniciou no Mestrado e se estendeu à realização desta pesquisa.

À Profa. Dra. Catharina Pinheiro Cordeiro dos Santos Lima e ao Dr. Elton Gloeden, geólogo da CETESB, pelas importantes contribuições durante a banca de qualificação.

À FAU e aos professores que possibilitaram momentos de discussão e reflexão, fundamentais para o desenvolvimento desta tese.

A todos os amigos com os quais pude compartilhar minhas ideias e angústias, recebendo em troca sugestões valiosas.

Aos meus pais, pelo suporte que têm me oferecido ao longo da vida, permitindo a finalização deste trabalho. 


\section{Resumo}

MORINAGA, Carlos Minoru. Áreas Contaminadas e a construção da paisagem pós-industrial na cidade de São Paulo. 2013. 201 p. Tese (Doutorado) Faculdade de Arquitetura e Urbanismo, Universidade de São Paulo, São Paulo, 2013.

Orientador: Prof. Dr. Paulo Renato Mesquita Pellegrino

As antigas áreas industriais na cidade de São Paulo têm sofrido uma progressiva perda das suas funções originais, tornando-se objeto de intensas transformações, particularmente no que diz respeito ao reaproveitamento dos imóveis e ao padrão de ocupação do solo existente, mediante a implantação de grandes empreendimentos imobiliários e a introdução de atividades totalmente diversas daquelas que as haviam caracterizado no passado. As formas pregressas de uso dessas áreas tornam possível a ocorrência de contaminação do solo e das águas subterrâneas, o que exige cuidados e procedimentos específicos para o reúso de terrenos ali localizados. Tendo como objeto de estudo a reutilização de antigas áreas industriais em processo de transformação na cidade de São Paulo, a presente tese parte da hipótese principal de que a construção de paisagens pós-industriais, sob a perspectiva da recuperação da função dos espaços urbanos e da garantia das condições de saúde pública e da sustentabilidade ambiental, só pode ser concebida no âmbito de um processo de gerenciamento de áreas contaminadas que contemple as dimensões interdisciplinar e interinstitucional da questão e leve em consideração a participação dos atores envolvidos. Tendo em vista que a reabilitação de áreas contaminadas abrange as dimensões básicas abordadas pelo que se passou a denominar sustentabilidade, a pesquisa teve início com o levantamento das diversas concepções adquiridas pelo termo, assim como das alterações ocorridas nas relações entre homem e natureza e suas implicações sobre as transformações observadas na paisagem ao longo do tempo, por meio de pesquisa bibliográfica. $\mathrm{O}$ tratamento dado ao problema das áreas contaminadas foi analisado a partir da forma de atuação fragmentada do poder público, mediante exemplos que demonstram a total ausência de integração entre os seus diferentes setores, e também do levantamento de instrumentos de incentivo à reabilitação de áreas contaminadas e de experiências internacionais sobre o tema. Considera-se, por fim, que além da visão interdisciplinar e interinstitucional, a reabilitação das áreas contaminadas na cidade depende da forma de atuação do poder público e da existência de mecanismos de incentivo.

Palavras-chave: paisagem urbana, contaminação, remediação, poluição do solo, áreas contaminadas, reabilitação. 


\section{Abstract}

MORINAGA, Carlos Minoru. Contaminated sites and the construction of the post-industrial landscape in the city of São Paulo. 2013. 201 p. Thesis (Doctorate) - Faculdade de Arquitetura e Urbanismo, Universidade de São Paulo (Faculty of Architecture and Urbanism, University of São Paulo), São Paulo, Brazil, 2013.

\section{Doctoral Program Advisor: Paulo Renato Mesquita Pellegrino}

The old industrial areas in the city of São Paulo have suffered a progressive loss of their former functions, becoming object of intense transformations, particularly concerning the use of the properties and the existing pattern of occupation of the land, through the construction of huge real estate projects and the introduction of activities totally different from those ones which characterized them in the past. The former uses of these areas make possible the occurrence of soil and groundwater contamination, what requires cares and specific procedures to reuse of the sites located in those places. Taking the reutilization of the old industrial areas in process of transformation in the city of São Paulo as the object of study, the present thesis starts from the main hypothesis that the construction of post-industrial landscapes, under the perspective of the urban space function recovery and the guarantee of the health public and the environmental sustainability, can only be conceived within the scope of a contaminated sites management process which satisfies the interdisciplinary and inter-institutional dimensions and takes into account the stakeholders involved in it. Considering that the rehabilitation of contaminated sites covers the basic dimensions treated by what was called sustainability, the research started with the survey of the various conceptions acquired by the term, as well as the changes occurred in the relationship between man and nature and its implications on the transformations of the landscape along the time, by means of bibliographical research. The treatment given to the contaminated sites issue was analyzed from the fragmented way of acting of the public administration, by means of examples which demonstrate the total lack of integration among their different sectors, and also from the survey of incentive instruments for the rehabilitation of contaminated sites and international experiences on the theme. At last, it's considered that, beyond the interdisciplinary and inter-institutional view, the rehabilitation of the contaminated areas in the city depends on the way the public sector acts and the existence of incentive mechanisms as well.

Key-words: urban landscape, contamination, remediation, soil pollution, contaminated sites, rehabilitation. 


\section{Lista de Ilustrações}

\section{Fotos}

Foto 1

Edifícios no entorno do Parque Burle Marx

Foto $2 \quad$ Indústria Packard Motors 53

Foto $3 \quad$ Indústria de rodas Kelsey Hayes 53

Foto $4 \quad$ Rich-Dex Apartments 53

Foto $5 \quad$ Indústria de Peças Automotivas Fisher Body 53

Foto $6 \quad$ Vista das instalações da antiga siderúrgica Thyssen 55

Foto 7 e $8 \quad$ Vista geral do Landschaftspark $\quad 55$

$\begin{array}{lll}\text { Foto } 9 & \text { Foto aérea do CEU - Butantã } & 58\end{array}$

Foto $10 \quad$ Foto aérea do CEU - Feitiço da Vila 58

Foto 11 e $12 \quad$ Foto aérea do CEU - Paz 59

Foto 13 Foto aérea do CEU - Três Pontes e da várzea do rio Tietê 60

Foto $14 \quad$ Foto da passarela de concreto construída sobre área alagadiça 62

Foto 15 Área da nascente, junto à Rodovia Raposo Tavares 70

Foto $16 \quad$ Vista do CEU - Butantã, ao centro 70

Foto 17 Vista aérea, com córrego Água Podre, ao centro, e favela 70 Imperatriz Dona Amélia abaixo

Foto 18 Favela Maria Lúcia, junto à Avenida Rio Pequeno, com 70 habitações a serem removidas

Foto 19 Córrego Água Podre, no trecho da linha de transmissão 70

Foto $20 \quad$ Vista aérea, com Trecho Esmeralda, ao centro 70

Foto 21 Área pública no Trecho Esmeralda: vista de montante para 71 jusante

Foto 22 Deslizamento do Morro do Bumba, Niterói - RJ, em abril de 2010

Foto 23 Obras de reconstrução do Morro do Bumba, Niterói - RJ, após deslizamento

Foto 24

Foto aérea da região de Brasilândia, com a localização 75 aproximada de duas áreas de deposição de resíduos sólidos, atualmente ocupadas 

pretende instalar um parque municipal

Foto 27

Foto 28

Foto 29

Foto 30

Foto 31

Foto 32

Foto 33

Foto 34

Foto 35

Foto 36

Foto 37

Foto 38

Foto 39

Foto 40

Foto 41

Foto 42

Foto 43

Foto 44

Foto 45

Vista do córrego Jacuí, com a área do parque Primavera, à esquerda, e a av. Jacu-Pêssego, à direita

Vista interna da área do parque com o bosque de eucaliptos, à direita, e um dos drenos de gases, à esquerda

Vista interna da porção do parque sem vegetação de porte arbóreo, com constatação de contaminação no solo

Vista geral da área do parque, à direita, e do córrego Jacuí e da av. Jacu-Pêssego, à esquerda

Edificação do antigo incinerador

Vista aérea da área do incinerador

84

Praça Vitor Civita com edificação do antigo incinerador

Praça Vitor Civita com sede da Editora Abril ao fundo

Praça Vitor Civita - deques de madeira

Praça Vitor Civita - deque de madeira e palco ao fundo

85

Foto aérea da Subprefeitura da Mooca, indicando a existência de Zonas Especiais de Interesse Social - ZEIS em antigas áreas industriais (ZUPI)

Empreendimento em São Caetano do Sul

Empreendimento em São Caetano do Sul

Empreendimento imobiliário na avenida Eusébio Stevaux, região de Jurubatuba, Santo Amaro

Empreendimento imobiliário na rua Borges de Figueiredo, Mooca

Empreendimento imobiliário na avenida Mofarrej, Vila Leopoldina

Vista da avenida Eusébio Stevaux, região de Jurubatuba, Santo Amaro

Mudança de uso na av.Eusébio Stevaux, região de Jurubatuba, Santo Amaro

Condomínio residencial de alto padrão na avenida Eusébio Stevaux, região de Jurubatuba, Santo Amaro 
Foto $47 \quad$ Novos empreendimentos imobiliários na avenida Eusébio
Novos empreendimentos na avenida Eusébio Stevaux, região de Jurubatuba, Santo Amaro
Foto $50 \quad$ Terreno destinado a empreendimento imobiliário na avenida Mofarrej, Vila Leopoldina Mofarrej, Vila Leopoldina, temporariamente utilizado como estacionamento

Foto 52

Foto 53

Foto 54

Foto 55

Foto 56

Foto 57

Foto 58

Foto 59

Foto 60

Foto 61 e 62

Vistas de antiga área industrial na rua Borges de Figueiredo, Mooca, na qual as edificações foram demolidas, remanescendo apenas a chaminé, para o lançamento de empreendimento imobiliário

Fotos 63 e 64 Vistas da antiga base da Esso, na Mooca, área contaminada em processo de remediação

Foto 65

Galpão industrial com mudança de uso na avenida Mofarrej, Vila Leopoldina

Novos empreendimentos em construção na avenida Mofarrej, Vila Leopoldina

Novos empreendimentos em construção na avenida Mofarrej, Vila Leopoldina

Vista do terreno na rua João A. Oliveira em 2005, com rua condomínio residencial.

Vista de condomínio residencial na João A. Oliveira em 2011, em terreno anteriormente ocupado por metalúrgica

Vista da rua Borges de Figueiredo, na Mooca, ainda com predominância de galpões industriais

Vista de galpão abandonado na rua Borges de Figueiredo, na Mooca

Grandes condomínios de edifícios residenciais ocupando antigas áreas industriais, Mooca 
Foto 66

Foto 67

Foto 68

Foto 69

Foto 70

Foto 71

Foto 72

Foto 73

Foto 74

Foto 75

Foto 76
Muros contínuos cercando os grandes condomínios, criando espaços desertos, Mooca

Vista de condomínio composto de grandes torres residenciais, na rua Sapucaia, Mooca

Vista de foto aérea de 2003, mostrando em vermelho antiga área industrial, atualmente ocupada por condomínio na rua Sapucaia, Mooca

Vista de condomínio composto de grandes torres residenciais, na avenida Cassandoca, Mooca

Foto 72 - Vista de foto aérea de 2003, mostrando em vermelho antiga área industrial, atualmente ocupada por condomínio na avenida Cassandoca, Mooca

Vista de condomínio residencial, na rua Taquari, Mooca

Vista de condomínio residencial, na rua Taquari, Mooca

173

Vista da avenida Henry Ford, Mooca, mostrando padrão de ocupação por galpões industriais, ainda em atividade

174

Vista de shopping center em construção na avenida Henry Ford, Mooca, na antiga área da fábrica da Ford

Vista da fábrica desativada da Antártica na avenida Presidente Wilson, Mooca

Vista de fábrica desativada na avenida Presidente Wilson, Mooca, ocupada por famílias de sem-teto

\section{Figuras}

Figura 1 Anúncio publicitário para empreendimento imobiliário, destacando a sua proximidade com o Parque Ibirapuera

Figura 2 Perspectiva da área do condomínio Barão de Mauá 76

Figura 3 Expo São Paulo - perspectiva geral do empreendimento 79

Figura 4 Expo São Paulo - área de hotéis 79

Figura 5 Plano Regional Subprefeitura Vila Maria/Vila Guilherme e ZUPI's 93 Lei Municipal 13.885/04 e Lei Estadual 1.817/78

Figura 6 Plano Regional Subprefeitura da Mooca e ZUPI's

Lei Municipal 13.885/04 e Lei Estadual 1.817/78

Figura 7 Plano Regional Subprefeitura Ipiranga e ZUPI's 
Figura 8 Distribuição das áreas contaminadas por tipo de atividade no estado de São Paulo

Figura 9 Anúncio do empreendimento

Figura 10 Anúncio do empreendimento

Figura 11 Panfleto publicitário do empreendimento

Figura 12 Mapa de Uso e Ocupação do Solo do Plano Regional Estratégico da 169 Subprefeitura da Mooca com a delimitação do Distrito da Mooca

Figura 13 Distrito da Mooca e Operação Urbana Mooca - Vila Carioca 180

\section{Quadros}

Quadro 1 Objetivos de sustentabilidade RESCUE

Quadro 2 Instrumentos e mecanismos destinados à reabilitação de áreas 154/157 contaminadas 


\section{Lista de Siglas}

\begin{tabular}{|c|c|}
\hline AIU & Área de Intervenção Urbana \\
\hline BDT & Boletim de Dados Técnicos \\
\hline CEPAC & Certificado de Potencial Adicional de Construção \\
\hline CERCLA & $\begin{array}{l}\text { Comprehensive Environmental Response Compensation and } \\
\text { Liability Act }\end{array}$ \\
\hline CETESB & Companhia Ambiental do Estado de São Paulo \\
\hline CEU & Centro Educacional Unificado \\
\hline CONAMA & Conselho Nacional do Meio Ambiente \\
\hline DEPAVE & $\begin{array}{l}\text { Departamento de Parques e Áreas Verdes, da Secretaria } \\
\text { Municipal do Verde e Meio Ambiente }\end{array}$ \\
\hline EMURB & Empresa Municipal de Urbanização \\
\hline FEMA & Superintendência de Habitação Popular \\
\hline FEPRAC & $\begin{array}{l}\text { Fundo Estadual para Prevenção e Remediação de Áreas } \\
\text { Contaminadas }\end{array}$ \\
\hline FUNDURB & Fundo de Desenvolvimento Urbano \\
\hline GTAC & Leadership in Energy and Environmental Design \\
\hline GTZ & Deutsche Gesellschaft für Technische Zusammenarbeit \\
\hline HIS & Habitação de Interesse Social \\
\hline HMP & Habitação do Mercado Popular \\
\hline OCDE & $\begin{array}{l}\text { Organização para Cooperação e Desenvolvimento } \\
\text { Econômico }\end{array}$ \\
\hline OSCIP & Organização da Sociedade Civil de Interesse Público \\
\hline OUC & Operação Urbana Consorciada \\
\hline PDE & Plano Diretor do Município de São Paulo \\
\hline PUE & Projeto Urbanístico Específico \\
\hline RCRA & Resource Conservation Recovery Act \\
\hline RESCUE & $\begin{array}{l}\text { Regeneration of European Sites in Cities and Urban } \\
\text { Environments }\end{array}$ \\
\hline
\end{tabular}


SABESP

SEHAB

SMSP

SVMA

TAC

TIF

USEPA

ZEIS

ZER

ZUPI
Companhia de Saneamento Básico do Estado de São Paulo Secretaria de Infraestrutura Urbana

Secretaria Municipal das Subprefeituras

Secretaria Municipal do Verde e Meio Ambiente

Termo de Ajustamento de Conduta

Tax Increment Financing

United States Environmental Protection Agency

Zonas Especiais de Interesse Social

Zonas Exclusivamente Residenciais

Zona de Uso Predominantemente Industrial (legislação estadual) 


\section{SUMÁRIO}

$\begin{array}{ll}\text { Introdução } & 15\end{array}$

$\begin{array}{ll}\text { Capítulo } 1 & 19\end{array}$

O conflito entre desenvolvimento econômico e conservação do meio ambiente

$\begin{array}{ll}\text { 1.1. A contextualização do problema } & 19\end{array}$

1.2. Os diferentes pontos de vista acerca do conflito entre 26 desenvolvimento e meio ambiente e da ideia de sustentabilidade

1.3. A interdisciplinaridade na questão ambiental 36

1.4. As áreas contaminadas no contexto da sustentabilidade e da 41 interdisciplinaridade

1.5. A cidade de São Paulo como cenário de conflitos na construção da 43 paisagem pós-industrial

Capítulo 2

As áreas contaminadas no contexto de uma abordagem fragmentada na cidade de São Paulo

2.1. A atuação fragmentada do poder público municipal nas questões ambientais

2.2. O gerenciamento das áreas contaminadas pelo poder público

2.3. A Legislação pertinente

96

Capítulo 3

103

A experiência internacional no gerenciamento de áreas contaminadas

3.1. As experiências internacionais no reúso de brownfields

3.2. Os aspectos projetuais

Capítulo 4

A recuperação de áreas contaminadas, a partir da perspectiva interdisciplinar e interinstitucional, na construção da paisagem pós-industrial na cidade de São Paulo

4.1. O processo de transformação das antigas áreas industriais

4.2. O gerenciamento de áreas contaminadas sob a perspectiva

135 interdisciplinar e interinstitucional 
4.3. A utilização de instrumentos urbanísticos, econômicos e ambientais destinados à reabilitação de áreas contaminadas, previstos nas legislações municipal e estadual

4.4. A participação da população na remediação de áreas 158 contaminadas

4.5. As oportunidades de transformação da paisagem industrial, a partir 165 do tratamento das áreas contaminadas - o exemplo da Mooca

$\begin{array}{ll}\text { Conclusão } & 185\end{array}$

$\begin{array}{lr}\text { Referências bibliográficas } & 191\end{array}$ 


\section{Introdução}

A cidade de São Paulo passou da situação de um modesto aglomerado urbano à condição de mais importante metrópole do país, a partir do crescimento da economia cafeeira e do impulso ao processo de industrialização, num movimento de recriações e sobreposições sucessivas de paisagens. A natureza, apropriada e modificada pela ação do homem desde o período colonial, tornou-se objeto e ao mesmo tempo recurso colocado à disposição do sistema produtivo, o que a colocou em situação extremamente vulnerável à progressiva devastação que se tem observado ao longo da história.

A forma de ocupação urbana que se segue no rastro da industrialização teve início com a instalação de galpões e habitações operárias, junto aos eixos ferroviários implantados sobre as várzeas dos rios que cortam a cidade. Os próprios cursos d'água não passaram incólumes ao terem seus traçados retificados ou canalizados, sob a impetuosidade do desenvolvimento urbano, tornando-se finalmente grandes depósitos de esgotos.

A apropriação do espaço em áreas urbanas mantém um estreito vínculo com a natureza, a partir do momento em que se utiliza dela como base física, estabelecendo-se aí uma dualidade na qual o conflito é um elemento constante que surge em decorrência da maneira como o modo de produção se organiza e define a configuração dos objetos no espaço.

A total ausência de controle sobre as fontes poluidoras, durante décadas, favoreceu as condições para o surgimento de diversas formas de contaminação ambiental na cidade. Nas áreas de várzea, sobre as quais foi assentada grande parte do parque industrial mais antigo da cidade, a situação de terrenos naturalmente alagáveis e com lençol freático elevado certamente tornou mais propícias as condições para o agravamento de possíveis ocorrências de contaminação do solo e das águas subterrâneas.

Diversas destas áreas têm assistido a uma progressiva perda da função industrial, tornando-se objeto de intensas transformações, particularmente no que diz respeito ao uso dos imóveis e ao padrão de ocupação existente, mediante a implantação de grandes empreendimentos imobiliários e a introdução de atividades totalmente diversas daquelas que as caracterizaram até pouco tempo atrás. 
A questão ambiental, por sua vez, tem conquistado maior espaço entre os grandes temas mundiais, diante dos constantes alertas da comunidade científica internacional acerca dos fatores que ameaçam a continuidade da vida no planeta, especialmente o aquecimento global. Por outro lado, a intensificação do nível de empobrecimento e de exclusão social de grande parcela da população torna-se mais evidente e adquire novos contornos no contexto de uma economia cada vez mais globalizada, lembrando que, numa eventual concretização das previsões calamitosas, os indivíduos mais afetados estarão nas camadas menos favorecidas da população.

Em regiões urbanizadas, os conflitos, que se constituem a partir da aparente incompatibilidade entre as atividades humanas e a proteção de áreas ambientalmente frágeis, elevam o nível de acirramento dos embates entre os que lutam pela qualidade das condições ambientais e os que defendem o desenvolvimento a qualquer custo. Ao mesmo tempo, a emergência dos conflitos socioambientais e a percepção do esgotamento dos recursos naturais e dos limites da sua capacidade de reprodução e regeneração propiciaram o surgimento da discussão acerca da noção de sustentabilidade, que não se configura como uma ideia homogênea, servindo, assim, aos mais diferentes propósitos.

A abordagem das questões ambientais, contudo, tem se realizado de maneira fragmentada, produzindo uma compreensão distorcida da realidade, o que muitas vezes acaba dando ensejo a políticas públicas equivocadas.

Dessa forma, a presente tese tem como objeto de estudo a reutilização de antigas áreas industriais em processo de transformação de uso e ocupação na cidade de São Paulo. Partindo dos pressupostos de que a recuperação urbana e ambiental e o reúso destas áreas exigem cuidados específicos, em razão do potencial de contaminação do solo e das águas subterrâneas, e de que o gerenciamento de áreas contaminadas só se concretiza de fato mediante uma perspectiva interdisciplinar e interinstitucional da questão, com a participação dos atores envolvidos, formula-se a hipótese de que as condições essenciais à construção de paisagens pós-industriais, que revelem a preocupação com a requalificação do espaço urbano e o cuidado com a saúde pública, segundo critérios que buscam a sustentabilidade ambiental, não estão totalmente presentes no atual contexto institucional, legal e social da cidade de São Paulo. 
O processo de remediação de áreas contaminadas e sua reutilização, com vistas à requalificação do espaço urbano, é ora tratada na literatura sob a denominação de revitalização, ora de reabilitação, além de outras designações. Assim, cabe aqui esclarecer que, no presente trabalho, ambos os termos serão empregados indistintamente com a mesma conotação.

A escolha do perímetro abrangido pelo Distrito da Mooca, integrante da Subprefeitura de mesmo nome, como área de estudo pautou-se pelas especificidades de suas características, considerando o fato de ser uma das regiões pioneiras no processo de industrialização da cidade de São Paulo, condição que implica a existência de um maior potencial de contaminação do solo e das águas subterrâneas, além de se encontrar em um período de grande transformação de usos com intensa atividade de implantação de novos empreendimentos imobiliários.

Com base no objeto deste estudo e no entendimento de que a reabilitação de áreas contaminadas envolve as dimensões básicas abordadas pelo que se passou a denominar sustentabilidade, a pesquisa iniciou-se pelo levantamento das diversas concepções adquiridas pelo termo, assim como das alterações ocorridas nas relações entre homem e natureza e suas implicações sobre as transformações observadas na paisagem ao longo do tempo. Esta tarefa foi realizada por meio de pesquisa bibliográfica, que procurou abranger autores com diferentes visões a respeito do tema. O tratamento dado ao problema das áreas contaminadas foi analisado a partir da forma de atuação fragmentada do poder público, com foco especial nas áreas de meio ambiente e desenvolvimento urbano, mediante a apresentação de exemplos que demonstram a absoluta falta de integração entre os diferentes setores que compõem a administração e as consequências disso sobre a efetividade das ações públicas e a vida da população. Ao mesmo tempo, foi efetuado o levantamento de algumas práticas internacionais no gerenciamento de áreas contaminadas, particularmente na Alemanha e nos Estados Unidos, países com grande experiência na matéria, dando ênfase aos mecanismos de incentivo à reabilitação. A atuação profissional deste autor no serviço público, nas áreas de habitação, meio ambiente e gerenciamento de áreas contaminadas, também contribuiu para a avaliação das questões relacionadas ao tema.

O trabalho insere-se na linha de pesquisa Sistemas da Paisagem: Recuperação de Áreas Ambientalmente Degradadas, da área de concentração de 
Paisagem e Ambiente, propondo a discussão sobre a utilização de mecanismos para a recuperação ambiental, urbanística e econômica de áreas comprometidas pela presença de substâncias prejudiciais à saúde pública e ao meio ambiente, com o objetivo de buscar a requalificação da paisagem urbana.

A tese estrutura-se em quatro capítulos, conforme os conteúdos descritos abaixo, tendo como foco principal a cidade de São Paulo.

O capítulo 1 busca discutir e contextualizar o conflito decorrente do embate entre desenvolvimento econômico e conservação ambiental, apresentando as contradições e as diferentes visões a respeito do problema, com especial atenção à ideia da sustentabilidade. Destaca, ainda, o caráter fundamental do tratamento interdisciplinar das questões ambientais, para em seguida inserir o assunto das Áreas Contaminadas e, finalmente, discorrer sobre a construção da paisagem pósindustrial na cidade de São Paulo.

No capítulo 2, trata-se basicamente da forma de atuação fragmentada do poder público municipal em seus diversos setores, com reflexos na área ambiental e, em particular, no gerenciamento das áreas contaminadas.

As experiências internacionais significativas no campo do gerenciamento de áreas contaminadas, visando o seu reúso, inclusive nos aspectos de projeto, constituem o assunto abordado no Capítulo 3.

Partindo do processo de transformação das antigas áreas industriais na cidade de São Paulo, particularmente o Distrito da Mooca, no Capítulo 4 discute-se a recuperação das áreas contaminadas, sob a perspectiva interdisciplinar e interinstitucional, mediante a possibilidade da utilização de instrumentos urbanísticos, econômicos e ambientais, para a construção de uma paisagem pósindustrial. 


\section{Capítulo 1}

\section{O conflito entre desenvolvimento econômico e conservação do meio ambiente}

\subsection{A contextualização do problema}

Há alguns milhares de anos, o homem primitivo já se utilizava de meios de expressão para revelar a sua relação com a natureza que o circundava. Mais do que uma simples demonstração da necessidade de manifestação artística, algumas teorias atribuem uma intenção mágica às pinturas rupestres e sustentam que o caçador, ao pintar a imagem de um animal na pedra, estaria procurando facilitar a sua captura, garantindo, em última instância, a obtenção dos recursos para a sua própria sobrevivência.

Essa forma de apreensão do real ao qual se associa uma concepção mágica da natureza pressupõe, conforme Duarte (1995), a existência de uma mentalidade "primitiva" encontrada no homem pré-histórico e nos povos indígenas, ou mesmo em traços de pensamento não científico que subsistem na consciência dos povos civilizados, guardando semelhança com o que Lévi-Strauss denomina de "pensamento selvagem".

Com referência a certas características presentes no discurso mágico de povos primitivos, Duarte (1995) menciona a ocorrência de uma lógica binária que não admite meio termo, ou seja, as coisas são ou não são, além da crença na ordenação de um passado dominado pelo caos, mediante a intervenção de um ente divino, geralmente idealizado sob a forma humana, num processo operado por meio do mecanismo da analogia, pelo qual traços inerentes ao ser humano são atribuídos aos fenômenos da natureza. Assim, na medida em que essas figuras imaginárias eram dotadas de grande poder, a concessão de favores aos homens, normalmente relacionada ao sucesso na colheita, na caça ou na pesca, estaria condicionada à privação ao exercício de determinadas ações, como forma de pagamento à divindade, enquanto que a ocorrência de infortúnios estaria ligada à violação de alguma proibição, e nesse sentido nada aconteceria por acaso.

A troca da atividade nômade pela fixação de uma atividade localizada representou a primeira ligação estável entre o homem e o seu espaço circundante, com o qual estabeleceu uma relação marcada por um acentuado sentido de 
sobrevivência, característica presente também nas civilizações da antiguidade, ao mesmo tempo em que se verificava um sentimento de profundo respeito e temor, bem como de impotência, diante da manifestação dos fenômenos naturais.

O desenvolvimento de práticas produtivas, como forma de garantir a subsistência, deu ensejo ao surgimento de uma completa transformação na relação entre homem e natureza. A evolução das técnicas de produção e a alteração das formas de organização social deram impulso à progressiva transformação da paisagem natural pela ação humana, intensificando o distanciamento entre os ritmos que caracterizam o processo de reprodução da natureza e o nível de exploração de seus recursos.

Assim, é possível afirmar que a degradação ambiental tem início a partir do momento em que os homens passam a se articular socialmente, fixando-se no território para o exercício de suas atividades, impactando em maior ou menor grau o meio no qual se estabelecem, de acordo com o modo como a sociedade se organiza, e em função das relações sociais de produção que se instauram a cada momento.

A ideia do homem como centro do universo e ser superior aos demais só veio a contribuir para reforçar a definição de uma concepção utilitária da natureza, segundo a qual a natureza e todas as coisas que a ela se referem só existiriam para servi-lo.

A superação da explicação teológica do mundo só ocorre com o advento da Revolução Mecanicista, no século XVII, que se caracterizou fundamentalmente pela adoção de uma concepção mecânica do conhecimento, a qual privilegiava o aspecto quantitativo e a compreensão dos fenômenos a partir de leis matemáticas, criando condições favoráveis ao desenvolvimento da ciência moderna. A este propósito, Duarte (1995) destaca o fato de que, naquele momento, deixa de existir uma oposição entre o saber teórico e o saber técnico, quando a ciência passa a se configurar prioritariamente como intervenção sobre a natureza com finalidades práticas e econômicas e, desde então, observa-se a afirmação do domínio do homem sobre a natureza.

A partir da Revolução Industrial, verifica-se um processo de aceleração progressiva da apropriação capitalista dos recursos naturais, que se mostra 
incompatível com a sua capacidade de reprodução e regeneração, revelando um traço característico do modo de produção hegemônico, que se baseia na propriedade privada dos meios de produção e na procura da maximização do lucro no curto prazo.

O processo histórico no qual se estabelecem a ciência moderna e a Revolução Industrial surge, segundo Leff (2009, p.62), como uma das principais causas da problemática ambiental, pois é nestas circunstâncias que se dá início à "distinção das ciências, ao fracionamento do conhecimento e à compartimentalização da realidade em campos disciplinares confinados, com o propósito de incrementar a eficácia do saber científico e a eficiência da cadeia tecnológica de produção".

Leff (2009) afirma que os processos produtivos, de acordo com a visão da acumulação capitalista, apresentam uma tendência à incorporação de um nível crescente de inovações tecnológicas, para promover a revalorização e o incremento da taxa de mais-valia, ao transferir esta estrutura tecnológica aos países "subdesenvolvidos", no âmbito da expansão do capital em escala global. Cria-se, então, uma organização produtiva dependente em relação aos países dominantes, que resultou na degradação da capacidade produtiva dos ecossistemas tropicais, especialmente com a introdução da monocultura e de pastos, e na perda de conhecimentos práticos desenvolvidos ao longo dos séculos pelas culturas tradicionais.

A racionalidade econômica, assim orientada pela busca permanente do aumento da produção e da eficiência a qualquer custo, reforçada pela concepção de natureza como algo que existe para servir ao homem, tem como sua consequência mais perversa a superexploração dos recursos naturais e a degradação das condições ambientais que, no longo prazo, podem até comprometer a própria continuidade do sistema econômico.

O debate que se trava em nível mundial a respeito da necessidade de se estabelecer mecanismos que promovam a sustentabilidade e que, em última instância, busquem salvar o planeta de uma catástrofe anunciada, visa, na realidade, deter o processo de aceleramento da extinção da própria espécie humana, uma vez que, na hipótese da concretização de tal possibilidade, a natureza continuará a existir, sem a presença do homem. 
A emergência da discussão da temática ambiental durante as últimas décadas, num quadro de crescente deterioração dos recursos naturais e de enormes desigualdades sociais, tem provocado o acirramento dos debates acerca das profundas contradições existentes entre as questões ambientais e sociais, levando a um constante confronto entre ambas.

A ideia comumente disseminada, que associa o ambiental à presença de ecossistemas naturais, induz a outro equívoco, que remete à tendência de se excluir o urbano do que se considera meio ambiente, como se configurassem universos distintos e sem nenhuma relação, apesar do irrefutável fato de que os fenômenos naturais continuam a atuar, mesmo em espaços densamente construídos, independentemente da vontade dos homens.

Por outro lado, os processos de transformação dos ecossistemas naturais não se limitam apenas às determinações das leis que regem a biologia e a ecologia, mas estão sujeitos também à influência das atividades humanas, especialmente nas áreas urbanas.

Essas questões reportam à discussão em torno da relação entre homem e natureza, ou entre sociedade e natureza, que se caracteriza como histórica, pois se altera ao longo do tempo e adquire diferentes conformações, em função do modo de organização da sociedade e das formas de apropriação econômica dos recursos naturais, que acabam por determinar o nível de degradação ambiental.

A relevância adquirida pelos problemas de caráter socioambiental, com destaque para o tema do aquecimento global, tem suscitado a proposição de novos modelos de desenvolvimento, baseados principalmente na ideia de sustentabilidade ambiental, os quais representam diferentes visões sobre o tema, desde aquelas que partem de uma concepção reducionista da questão até as que vislumbram a mudança do modo de produção vigente como solução para uma possível reversão dos efeitos adversos da degradação.

A própria noção de sustentabilidade ambiental, como dimensão a ser incorporada ao processo de desenvolvimento, adquiriu interpretações diversas e até divergentes, tornando-se inclusive objeto de apropriação pelo mercado como fator de valorização de determinados produtos, o que gerou uma certa tendência à vulgarização do termo. 
Ainda que as evidências a respeito do agravamento das condições ambientais globais tenham se manifestado de modo mais claro nos últimos anos, o discurso desenvolvimentista em defesa da necessidade da criação de empregos para promover a melhoria do nível de renda da população parece ter se tornado recorrente no cenário político brasileiro, reforçando a ideia de desenvolvimento associada exclusivamente ao incremento do Produto Interno Bruto. Uma das críticas mais veementes dos defensores deste posicionamento recai sobre os procedimentos de licenciamento ambiental que "emperram" a implantação de empreendimentos "indispensáveis" ao desenvolvimento econômico, gerando uma movimentação no sentido de promover a sua "simplificação" como se fossem meros atos administrativos a serem cumpridos para a liberação e legalização de empreendimentos extremamente impactantes e nem sempre tão eficientes.

A flexibilização do processo de licenciamento ambiental nesse contexto tornase ainda mais preocupante diante da perspectiva da realização de grandes eventos no país, com alcance mundial, nos próximos anos, que exigirão a realização de grandes obras com significativo impacto sobre o meio em que serão implantados, cujos benefícios sociais presentes e futuros são altamente questionáveis.

Numa tentativa de se atribuir um caráter de legitimidade à degradação imposta aos recursos naturais, particularmente quando ela é produzida em nome do "desenvolvimento", proliferam os instrumentos de compensação ambiental e os mecanismos de precificação dos danos como estratégias para garantir uma suposta sustentabilidade, que efetivamente não se concretiza.

No debate recentemente travado no Congresso Nacional sobre o projeto de mudança do Código Florestal, uma das questões mais polêmicas referiu-se à definição dos percentuais das propriedades ou posses rurais a ser destinadas à reserva legal e a inclusão das áreas de preservação permanente neste cálculo. A reserva legal corresponde a porções representativas dos ambientes naturais locais que exercem papel fundamental para a conservação da biodiversidade e dos processos ecológicos. A este respeito, a senadora Kátia Abreu manifestou-se publicamente contra a manutenção da reserva legal, que classificou como "corpo estranho" na propriedade rural que afeta o lucro. Em sua opinião, segundo reportagem do jornal O Estado de São Paulo, de 07/12/2010, deveria haver uma separação entre unidades de produção e unidades de conservação, pois, de acordo 
com a sua declaração, "se eu coloco um corpo estranho numa unidade de produção econômica, atrapalho essa engrenagem", devendo a função de preservação ser exercida pelos parques nacionais, estaduais e municipais.

Outros aspectos polêmicos nas propostas apresentadas para a alteração do Código Florestal envolveram a revisão do tamanho das áreas de preservação permanente e a possibilidade de utilizá-las para atividades produtivas, assim como a anistia aos desmatamentos realizados até julho de 2008.

As tentativas de modificação do enquadramento de áreas consideradas de preservação permanente também são muito fortes, particularmente quanto à exclusão dos topos de morros e à redução das faixas de proteção ao longo dos cursos d'água. As grandes tragédias ocorridas em Santa Catarina, Angra dos Reis e na região serrana do estado do Rio de Janeiro, durante os períodos de chuva mais intensa, entre 2011 e 2012, demonstram a fragilidade dos terrenos de encosta e das margens de rios, cada vez mais ocupados e gerando situações de risco. Além disso, os escorregamentos em áreas de encosta são fenômenos potencializados pela interferência das atividades humanas em regiões como a Serra do Mar. Assim, a exclusão destas áreas da condição de preservação permanente certamente criaria a oportunidade para a legalização de ocupações, assim como para a ocorrência de novas tragédias, com um número crescente de vítimas.

A despeito de todas as polêmicas a respeito da aplicabilidade do Código Florestal em áreas urbanas, as enchentes que se repetem a cada chuva mais intensa na cidade de São Paulo, invariavelmente nos mesmos locais, denunciam a impropriedade das formas de ocupação urbana ao longo da história em áreas naturalmente destinadas ao espraiamento das águas. Em alguns deles, por mais investimentos que se apliquem em obras suntuosas e impactantes, os problemas tendem a persistir, numa luta insana contra fatores sobre os quais não se possui o domínio.

A Constituição Federal de 1988 dedica um capítulo especialmente ao meio ambiente, definindo-o como bem de uso comum do povo, fato que Fuks (2001) identifica como uma tendência do direito brasileiro de reconhecer o caráter de universalidade do interesse pela proteção ambiental. Em que pese a real gravidade dos problemas ambientais e de seus efeitos, o sentido de consenso, de comprometimento geral em torno de objetivos comuns, presentes nesta concepção, 
faz pressupor a existência de uma sociedade homogênea, sem os conflitos e as contradições inerentes à realidade e ao modo de produção no qual está inserida.,

Ao abordar a problemática ambiental e as demandas encaminhadas por setores organizados da sociedade aos órgãos do Estado, incluindo o Ministério Público, na cidade do Rio de Janeiro, Fuks (2001) conclui que são os conflitos centrados no uso do solo que tendem a assumir o caráter de conflito ambiental, situação que certamente deve prevalecer na maior parte das cidades brasileiras. Este deslocamento de foco, segundo o autor, tem como consequência fundamental a recolocação da questão ambiental como problema social, e é justamente essa multiplicidade de sentidos que impede que se atribua a ela o caráter de universalidade, pois ao inseri-la no campo das relações sociais, ela passa a ter um significado diferente para cada grupo.

Ainda de acordo com Fuks (2001, p.77), os interesses associados à proteção do meio ambiente excluem os interesses individuais, mas "não se confundem com os interesses do 'Estado como pessoa jurídica', os quais não coincidem, necessariamente, com os da sociedade", uma vez que o Estado reflete o interesse de grupos sociais. Como decorrência deste fato, o encaminhamento de soluções de problemas urbanos e ambientais acaba se vinculando a interesses específicos.

Outro aspecto dessa discussão diz respeito à crescente fragmentação do conhecimento em campos disciplinares distintos, engendrada a partir do estabelecimento da ciência moderna e do advento da Revolução Industrial, com o intuito de se promover o aumento da eficiência dos processos produtivos, que pode ser considerada como uma das principais causas da degradação dos recursos naturais, na medida em que a pulverização do saber em compartimentos estanques acarreta a perda da compreensão das complexas inter-relações que mantêm as condições necessárias à estabilidade ambiental global. Torna-se, portanto, urgente a árdua tarefa de buscar meios que possibilitem a reintegração do conhecimento, com base numa visão interdisciplinar e interinstitucional da questão ambiental, que na realidade envolve dinâmicas de ordem natural e social, por vezes contraditórias.

A conjugação de elementos, como a exploração predatória dos recursos naturais, a geração progressiva de poluentes e a difusão de práticas inadequadas de destinação de resíduos, geralmente relacionadas aos processos produtivos, criou as condições para o surgimento de diferentes formas de degradação do meio ambiente, 
entre as quais a poluição do solo e das águas subterrâneas, principal característica dos sítios conhecidos como "áreas contaminadas", que constituem o campo de interesse deste estudo.

\subsection{Os diferentes pontos de vista acerca do conflito entre desenvolvimento e meio ambiente e da ideia de sustentabilidade}

A utilização do termo sustentabilidade por diversos segmentos sociais tem provocado uma grande ambiguidade a respeito do seu significado, permitindo que seja empregado de acordo com a conveniência de quem dele faz uso, como ocorre no caso de sua apropriação pelo mercado.

O emprego do adjetivo sustentável, como lembra Veiga (2007), permaneceu restrito até os anos 70 ao campo da biologia populacional, por exemplo, na estimativa dos limites de reprodução de determinadas atividades extrativas ou do ponto de rompimento da resiliência dos ecossistemas. Todavia, quando passou a ser integrado à esfera do desenvolvimento, o termo começou a ser empregado de forma arbitrária, geralmente na acepção de algo duradouro ou permanente, para as mais diversas situações.

Veiga (2007) aponta três concepções diferentes de sustentabilidade, a mais preponderante delas, associada aos economistas convencionais, que vincula a melhoria das condições ambientais de um país ao seu enriquecimento, aferido em termos do aumento de sua renda per capita, baseada na demonstração empírica de que o nível de deterioração ambiental apresentaria uma elevação nas fases iniciais do processo de crescimento, tendendo a uma inversão da situação a partir de um determinado valor da renda per capita, quando ocorreria um aumento da demanda (e da oferta) pela proteção ambiental, que seria superada por meio da inovação científica e tecnológica. A segunda concepção apoia-se nos princípios da termodinâmica e considera que uma parcela da energia destinada às atividades humanas sempre se dissipa, não podendo ser mais utilizada, situação que levaria ao aumento da entropia e à possível extinção da espécie humana, o que significaria dizer que "a sustentabilidade não deve ser confundida com a ilusão da perenidade". A teoria da "condição estacionária", desenvolvida pelo economista Herman E. Daly ${ }^{1}$,

\footnotetext{
${ }^{1}$ DALY, Herman E. "Sustentabilidade em um mundo lotado". In Scientific American Brasil. São Paulo, outubro de 2005.
} 
se apresentaria como uma variável desta versão defendendo que a sustentabilidade poderia ser obtida pela adoção de uma visão qualitativa, sem prejuízo do crescimento, por exemplo, com a substituição da matriz energética por fontes renováveis. O terceiro ponto de vista a respeito da noção de sustentabilidade rejeita a premissa, presente na primeira concepção, de que os ecossistemas poderiam ser substituídos por capital e trabalho, mas opõe-se à proposição de que os países mais desenvolvidos devam renunciar ao crescimento econômico, por se entender que "cada geração deve legar à sucessora pelo menos tanta riqueza per capita quanto ela própria herdou".

Cabe ressaltar aqui a distinção que Veiga (2006, p.23) faz entre crescimento econômico e desenvolvimento, frequentemente tidos como sinônimos, afirmando que o desenvolvimento só ocorre "quando os benefícios do crescimento servem à ampliação das capacidades humanas, entendidas como o conjunto das coisas que as pessoas podem ser, ou fazer, na vida", mediante a condição fundamental da liberdade de escolha. Sob este ponto de vista, o conceito tradicional de crescimento econômico, baseado no nível do Produto Interno Bruto (PIB), pode ser considerado anacrônico, na medida em que este não inclui a depreciação de determinados ativos, como os recursos naturais, além do fato de que, para o seu cálculo, não importa se o crescimento é obtido à custa do pagamento de salários baixíssimos, ou se é decorrente da exploração de trabalho escravo ou infantil, ou mesmo da venda de armas.

A ideia de sustentabilidade associada à busca da conciliação entre desenvolvimento econômico e preservação ambiental indica uma mudança de enfoque sobre as questões ambientais, em relação à visão conservacionista predominante até algumas décadas atrás, como enfatiza Costa (1999). Desde então, surgiram diversos pontos de vista a respeito deste tema, especialmente no rastro das grandes conferências internacionais.

A Conferência das Nações Unidas sobre o Meio Ambiente, realizada em 1972 na cidade de Estocolmo, constituiu um marco nas discussões sobre as relações entre homem e meio ambiente, apesar da posição dos representantes brasileiros que declararam que o país estaria de braços abertos ao recebimento de empresas poluidoras e disposto a pagar o preço da degradação ambiental, desde que o resultado fosse o aumento do Produto Interno Bruto. Em meio à polêmica gerada 
entre posições divergentes, o Secretário da Conferência, Maurice Strong, propôs a ideia de ecodesenvolvimento, posteriormente formulada, de forma detalhada, pelo economista Ignacy Sachs.

O ecodesenvolvimento sugere uma alternativa intermediária entre 0 economicismo desenvolvimentista e o ecologismo exacerbado, por meio do crescimento econômico, ainda necessário, porém fundamentado em estratégias de desenvolvimento que tenham como foco o "aproveitamento racional e ecologicamente sustentável da natureza em benefício das populações locais", deixando de "favorecer a incorporação predatória da natureza ao PIB" (SACHS, 2009, p. 53).

Ao possibilitar que as populações incorporem as preocupações com a conservação dos recursos naturais, em especial a partir da valorização dos recursos próprios dos ecossistemas locais, com o objetivo de atender às suas necessidades fundamentais, o desenvolvimento passa a enfatizar o aspecto qualitativo, assimilando os custos ecológicos e sociais, o que requer a adoção de "padrões negociados e contratutais de gestão da biodiversidade". Sachs (2009, p. 60) ressalta a necessidade de "uma combinação viável entre economia e ecologia, pois as ciências naturais podem descrever o que é preciso para um mundo sustentável, mas compete às ciências sociais a articulação das estratégias de transição rumo a este caminho".

A expressão "desenvolvimento sustentável" é proposta durante a Conferência Mundial sobre a Conservação e o Desenvolvimento, da International Union for Conservation of Nature - IUCN, em 1986, na cidade de Ottawa, Canadá, como novo paradigma de desenvolvimento, fundado nos seguintes princípios: integração entre conservação da natureza e desenvolvimento; satisfação das necessidades humanas fundamentais; perseguição da equidade e da justiça social; busca da autodeterminação social e da diversidade cultural e manutenção da integridade ecológica.

O documento intitulado Nosso Futuro Comum, também conhecido como Relatório Brundtland e apresentado em 1987, é o resultado de um trabalho desenvolvido pela Comissão Mundial sobre o Meio Ambiente e Desenvolvimento, constituída no âmbito da Organização das Nações Unidas, em 1984, a partir do reconhecimento das enormes desigualdades sociais e econômicas verificadas entre 
as nações do mundo, quando se retoma a ideia de desenvolvimento sustentável. Aqui a alternativa que se propõe para a superação do problema fundamenta-se na necessidade de se promover o crescimento econômico, visto como condição essencial à minimização da pobreza mundial, que deve ser levado a efeito com base em práticas que procurem conservar e ampliar a base de recursos ambientais, com o objetivo de suprir o atendimento das necessidades do presente, sem comprometer a capacidade das gerações futuras de satisfazer as suas próprias necessidades. Assim, o atendimento das necessidades básicas de todos estaria condicionado ao crescimento econômico das nações, e o desenvolvimento sustentável encontraria os seus limites no estágio atual da tecnologia e da organização social e na capacidade da biosfera de absorver os impactos decorrentes das atividades humanas.

Reconhecendo as inevitáveis dificuldades para a implementação de políticas públicas baseadas na noção de desenvolvimento sustentável, tanto no nível das organizações nacionais como no dos organismos internacionais, o relatório faz recomendações para que sejam promovidas mudanças de caráter institucional e legal. Os obstáculos internos às nações estariam relacionados à tendência à atuação independente e fragmentada das entidades governamentais, assim como à limitação das atribuições de cada uma delas e aos processos fechados de decisão, situação que se comprova na desvinculação das ações das instituições nacionais responsáveis pela administração dos recursos naturais e proteção do meio ambiente e das que se dedicam à administração da economia.

O documento ainda parte da compreensão de que as políticas que visam prevenir e evitar os danos ambientais não devem se restringir apenas aos aspectos ecológicos da questão, mas também considerar os seus aspectos econômicos, comerciais, energéticos, agrícolas e outros, e faz recomendações de diretrizes focadas nas áreas de segurança alimentar, extinção de espécies e esgotamento de recursos energéticos, energia, indústria e assentamentos humanos.

Nessa discussão que envolve múltiplas visões acerca da problemática ambiental, enquanto alguns defendem a posição de que o desenvolvimento sustentável seria uma evolução do ecodesenvolvimento, outros os consideram sinônimos, e ainda que possam ser reconhecidos pontos de convergência entre as propostas, deve se admitir a existência de aspectos discordantes entre ambas. 
Como pontos básicos de consenso entre ecodesenvolvimento e desenvolvimento sustentável podem ser citados o compromisso ético com os direitos das futuras gerações, a dimensão ambiental como parte do processo de desenvolvimento, a participação das comunidades locais nos processos decisórios e a preocupação com o bem-estar social.

Por outro lado, autores como Layrargues (1998) encontram diferenças relevantes entre as duas propostas. Assim, a noção de justiça social no ecodesenvolvimento estaria relacionada à busca de um nivelamento médio dos padrões de consumo entre os países do "Norte" e do "Sul", ao passo que, no desenvolvimento sustentável, o "piso de consumo material" seria atingido pelo crescimento econômico tanto do "Sul" como do "Norte", por meio de tecnologias mais eficientes e menos poluentes, que produziriam mais bens com uma quantidade menor de recursos. Dessa forma, a tecnologia, do ponto de vista do ecodesenvolvimento, estaria atrelada às condições naturais de cada ecossistema e das especificidades culturais das respectivas regiões, enquanto que a transferência de tecnologias do "Norte" para o "Sul" é considerada fundamental no processo do desenvolvimento sustentável.

Na visão de Leff (2009, p.216), no entanto, o ecodesenvolvimento apresenta um discurso essencialmente prático, que procura "harmonizar a reprodução da natureza como objetos e meios do processo produtivo na reprodução ampliada de capital", mediante a refuncionalização da racionalidade econômica com a incorporação de "uma 'dimensão ambiental' às políticas de desenvolvimento", sem, contudo, questionar a possibilidade de concretizar os seus objetivos "dentro dos paradigmas econômicos e das estruturas institucionais prevalentes".

Contudo, ao assumir uma postura mais restritiva quanto à atuação do mercado, o discurso ecodesenvolvimentista acabou sendo preterido pelo capital, que encontrou, posteriormente, uma versão mais palatável no desenvolvimento sustentável, o qual também passou a ser assumido como paradigma pelo movimento ambientalista, a partir do final dos anos 80.

O conceito de desenvolvimento sustentável tem adquirido conotações diversas ao longo dos últimos anos, englobando diferentes abordagens que se orientam no sentido de buscar o objetivo comum de conciliar crescimento econômico, justiça social e meio ambiente, o que permitiria alcançar a melhoria da 
qualidade de vida dos atuais habitantes do planeta, sem comprometer as necessidades das próximas gerações. Tal amplitude resulta numa espécie de consenso em relação às propostas que se apoiam na questão da sustentabilidade, como se fosse um ideal compartilhado por todos os países e que atendesse a todos os interesses, o que expõe o caráter ambíguo e vago do conceito, possibilitando a sua apropriação de acordo com a conveniência dos diferentes grupos sociais.

A aparente neutralidade ideológica manifesta no discurso predominante da sustentabilidade é pautada por princípios idealizados de solidariedade global, na busca de uma compatibilização entre preservação ambiental e justiça social, que, no entendimento de Loureiro (2003, p.37), fica restrita ao plano moral e não ao estrutural, "como se o problema determinante dependesse unicamente, para ser resolvido, da superação individual de uma abstrata falta de ética e de consciência ambiental".

A concepção dominante do desenvolvimento sustentável defende o crescimento econômico contínuo, apoiado nos mecanismos de mercado, como via para a redução da pobreza, delegando às soluções técnicas não só a função de promover o aumento da produtividade, mas também de reverter os efeitos adversos resultantes dos processos produtivos e de consumo, porém, ignorando os fatores ambientais que impõem limites à exploração dos recursos naturais.

Os sucessivos entraves para se alcançar acordos internacionais rumo à sustentabilidade, como tem sido comprovado nas tentativas de se chegar a um consenso na questão das emissões dos gases do efeito estufa, demonstram as contradições presentes na internalização de critérios ecológicos à lógica da acumulação capitalista, que se caracteriza pela busca constante da expansão econômica orientada pelo mercado e, indiretamente, da apropriação dos recursos naturais.

O mercado, por usa vez, utiliza-se de estratégias que procuram incorporar o discurso da sustentabilidade nos diversos setores produtivos, tendo na construção civil uma das áreas que mais tem atuado nesta direção.

Porto (2009) aponta o congresso da União Internacional de Arquitetos, realizado em Chicago, logo após a Eco-92, como o encontro no qual os arquitetos tomaram posição em favor da elaboração de projetos ecoeficientes. Refere-se ao 
arquiteto Ladislao Szabo ${ }^{2}$ para listar os principais requisitos para a concepção de um edifício sustentável ou "verde", que deveria inicialmente partir da consideração da redução dos impactos resultantes de sua implantação sobre o entorno, em termos urbanísticos, topográficos, de infraestrutura, de permeabilidade do solo e manutenção da vegetação existente, entre outros aspectos, procurando a sua integração física e social ao local.

Do ponto de vista da edificação, o projeto deveria compatibilizar-se às condicionantes ambientais locais e ao emprego de mecanismos de economia de energia, de captação de águas pluviais, de tratamento de efluentes, de armazenamento de resíduos, além do uso de fontes de energia limpa e renovável e de materiais ambientalmente adequados. Deveria, também, atender aos aspectos de segurança, conforto ambiental, ergonomia, acessibilidade e relação com a comunidade e a cidade, bem como a preservação dos aspectos culturais locais.

Dentro desse conceito, foram desenvolvidos alguns sistemas de certificação de edificações sustentáveis, dentre os quais o LEED (Leadership in Energy and Environmental Design). Entretanto, o que aparentemente tais sistemas objetivam alcançar é o atendimento às novas exigências do mercado, que visam agregar não só a componente ambiental, mas também valor aos produtos que oferecem aos consumidores sensibilizados pela questão ecológica, ensejando o surgimento da justificativa da "valorização sustentável" por parte do setor imobiliário.

A transposição de sistemas de certificação importados cria certas incongruências, especialmente quando se dá o rótulo de sustentável a edifícios totalmente envolvidos por grandes painéis de vidro nas fachadas em regiões de clima tropical os quais, mesmo utilizando-se de materiais com propriedades isolantes, necessitam de sofisticados sistemas de ar condicionado para manter o conforto dos usuários, o que resulta num consumo considerável de energia elétrica, cujo processo de geração invariavelmente causa impactos ambientais irreparáveis. Além do mais, é oportuno lembrar que as soluções de sombreamento e ventilação empregadas pela arquitetura moderna ainda continuam válidas e eficazes.

A aplicação de sistemas de certificação no Brasil tem centrado a sua análise muito mais na edificação do que na sua inserção no contexto urbano, o que gera

\footnotetext{
${ }^{2}$ SZABO, Ladislao. "A arquitetura no caminho da sustentabilidade". In Iniciativa Solvim 2005. São Paulo
} 
situações contraditórias. Tome-se como exemplo o caso da região da Marginal do rio Pinheiros, em São Paulo, sobretudo no trecho localizado próximo à avenida Luiz Carlos Berrini, área ocupada por sedes de grandes corporações e de hotéis de luxo na cidade, muitos deles ocupando edifícios grandiosos considerados "inteligentes", que empregam tecnologias para otimizar o consumo de água e energia, além de atender a outros "quesitos de sustentabilidade". Tais edificações vêm sendo construídas sobre um traçado urbano que até pouco tempo atrás abrigava construções horizontais de pequeno porte, com um sistema viário local subdimensionado, o que aliado aos conhecidos gargalos constituídos pela Marginal do rio Pinheiros e pelas travessias do próprio rio, não apresenta capacidade para suportar o volume de veículos gerado pela concentração de novas edificações que se multiplicam na região, principalmente nos horários de pico, criando uma situação de absoluta insustentabilidade.

Mesmo reconhecendo a importância da incorporação de práticas que contribuam para minimizar os impactos sobre os recursos ambientais ao campo da arquitetura e do urbanismo, é preciso ressaltar que grande parte dos requisitos a serem atendidos para se atribuir a condição de sustentável a uma edificação referese às condicionantes básicas que sempre foram exigidas de qualquer projeto arquitetônico considerado de boa qualidade, independentemente do rótulo de sustentável.

Em contraposição à ideia corrente de sustentabilidade, colocam-se algumas visões críticas com relação ao ideário do desenvolvimento sustentável como expressão do modo de produção dominante.

A partir de uma visão crítica do sistema capitalista, Leff (2009, p.285-300) refere-se à tendência à homogeneização dos modelos produtivos, dos padrões de consumo e dos estilos de vida, que conduz à desestabilização dos processos ecológicos. Discorre, então, sobre a necessidade do estabelecimento de "novos princípios valorativos e forças materiais para reorientar o processo de desenvolvimento", formulados sob a forma de uma racionalidade ambiental, sobre a qual o processo de desenvolvimento deveria ser reorientado, em oposição à visão calcada na racionalidade econômica.

A racionalidade ambiental, segundo o referido autor, teria como objetivo precípuo o estabelecimento de um balanço entre crescimento econômico e 
conservação dos recursos naturais, a ser alcançado mediante a mobilização do potencial dos processos ecológicos, da inovação científico-tecnológica, da diversidade cultural e da participação social, na construção do que denomina de "bases e meios ecotecnológicos de produção" para um desenvolvimento sustentável, que se caracteriza como "igualitário, descentralizado, autogestionário e ecologicamente equilibrado, capaz de satisfazer as necessidades básicas da população, respeitando a sua diversidade cultural e melhorando a sua qualidade de vida" (LEFF, 2009, p.287).

A constituição de uma racionalidade ambiental assim concebida não se restringiria, portanto, à simples internalização das condicionantes ecológicas aos mecanismos regidos pela racionalidade econômica, pelo contrário, implicaria a implementação de processos de desconstrução da lógica dominante do mercado, assim como de mudanças das instituições e dos aparelhos ideológicos que a sustentam. Dessa forma, esta nova racionalidade produtiva estaria embasada em princípios e valores que não permitiriam que suas estratégias pudessem ser avaliadas em termos de um cálculo econômico, rejeitando, assim, a ideia de meio ambiente como uma simples variável de mercado.

Leff (2007, p.134) ainda admite que "a construção de uma racionalidade ambiental implica a realização e concreção de uma utopia", porém não a reconhece como a "materialização de princípios ideais abstratos", por entendê-la como "um projeto social de resposta a outra racionalidade que teve seu período histórico de construção, legitimação, instrumentalização e de tecnologização".

A transposição do termo sustentabilidade à esfera ambiental, relacionando-o à questão do desenvolvimento, deu margem à sua apropriação por diferentes segmentos, a partir de entendimentos distintos e por vezes controversos. Veiga (2010, p.13) destaca a impossibilidade de se chegar a definições precisas com relação a grande parte das ideias, sobretudo quando exprimem valores, o que impede o seu enquadramento na categoria de conceito. É o que ocorre com a noção de sustentabilidade que, desta forma, não deveria ser tratada como um conceito, mas sim como um novo valor.

Nesse sentido, Veiga (2010) identifica a origem da discussão sobre a ideia de sustentabilidade nas reflexões levadas a efeito pela ecologia e pela economia. Assim, enquanto a ecologia fazia a transição de uma ideia inicial de sustentabilidade 
ecossistêmica relacionada a um presumido "equilíbrio", para a noção de resiliência, isto é, a capacidade de um sistema para absorver impactos e recuperar-se, a economia ainda se debate entre diferentes concepções, que se situam entre a corrente dominante, que entende que a sustentabilidade só pode ser garantida pela maximização do crescimento econômico, e a visão que defende a condição "estacionária" de expansão da economia. De qualquer modo, admite que a sustentabilidade só poderá ser atingida por meio de uma macroeconomia que reconheça os limites dos recursos naturais ao crescimento das atividades econômicas, da mesma forma que rompa com a lógica social do consumismo. Enfatiza também a urgente necessidade de mecanismos que reduzam a disparidade de capacidades tecnológicas entre o Primeiro Mundo e os países emergentes, embora se mostre pessimista quanto ao prazo para se implementar as transformações indispensáveis para deter o aquecimento global e mesmo com relação à disponibilidade das nações de se engajarem nesta empreitada, independentemente de seu nível de desenvolvimento econômico.

Reconhecendo que a aceitação universal do termo desenvolvimento sustentável deve-se justamente à sua imprecisão, o que o torna objeto de apropriação por vários grupos sociais de interesse, de forma diferenciada, Montibeller (2008, p. 61) vale-se da definição de Rattner, para corroborar com a concepção de desenvolvimento sustentável como "um processo contínuo de melhoria das condições de vida (de todos os povos), enquanto minimize o uso de recursos naturais, causando um mínimo de distúrbios ou desequilíbrios ao ecossistema". Admite, contudo, que as decisões que colocam a possibilidade de acumulação continuada do capital em situação efetiva de risco são totalmente incompatíveis com a racionalidade dominante no sistema, que é econômica.

Montibeller observa que, no curto e médio prazo, o capital pode favorecer a natureza e vice-versa, situação que, no longuíssimo prazo, tende a não se sustentar, como no exemplo de empresários que procuram se diferenciar no mercado, por meio da produção de "ecoprodutos", em tese, fabricados e consumidos de modo a produzir menores impactos ao meio ambiente, uma vez que a disseminação generalizada de tal prática implicaria o desaparecimento dessa forma de obtenção de superlucro. Nestas condições, a obrigação de assumir o custo ambiental para produzir de forma ecologicamente correta, em função de uma demanda da 
sociedade, levaria a uma redução da escala produtiva e à obtenção de um lucro menor, o que tenderia a se agravar com o tempo.

A abordagem da questão do desenvolvimento sustentável numa macrovisão do capitalismo, sob uma perspectiva de prazo secular, realizada por Montibeller, conclui pela impossibilidade de se atingir o desenvolvimento sustentável, com suas dimensões básicas de equidades intrageracional, intergeracional e internacional, em escala global, no mundo capitalista. Reconhece, porém, que tal constatação "não invalida os esforços que visam a processos de transformação das condições socioeconômicas com uma melhor relação do homem com a natureza", considerando, ainda, que a compreensão acerca dos limites desses processos não significa imobilização, mas sim "ampliar a consciência do alcance das ações".

Os tempos da natureza, especialmente aqueles necessários à regeneração e reprodução dos seus recursos, bem como as condições indispensáveis à manutenção dos ecossistemas, impõem limites aos níveis de exploração e de consumo inerentes à racionalidade econômica vigente. Contudo a busca pela crescente maximização do lucro que caracteriza o modo de produção capitalista evidencia a sua tendência à utilização de formas predatórias de apropriação dos recursos naturais e ambientais, que levam ao seu esgotamento e à sua degradação. Entretanto, diferentemente da posição defendida por Leff, corrobora-se neste trabalho com o ponto de vista manifestado por Montibeller de que, embora admitindo a inviabilidade de se atingir um patamar de sustentabilidade global, em suas dimensões básicas, no atual sistema produtivo, as ações que visam à sustentabilidade e procuram estabelecer novos paradigmas socioeconômicos, dentro de uma racionalidade ambiental, não podem ser desprezadas e devem ser cada vez mais demandadas, naturalmente com a devida cautela para não se incorrer em concepções tendentes à homogeneização do termo sustentabilidade.

\subsection{A interdisciplinaridade na questão ambiental}

Há uma tendência generalizada e equivocada de se associar o ambiental exclusivamente ao natural, porém, se o meio ambiente for compreendido como o resultado das relações entre os processos naturais e os processos sociais, as quais se estabelecem de forma mais conflituosa e intensa nas áreas urbanas, conclui-se que os embates verificados entre ambas as esferas configuram-se como problemas 
ambientais que, na realidade, decorrem das formas como os indivíduos se organizam socialmente e de como estas formações sociais se apropriam do espaço e dos recursos naturais.

A frequente identificação do meio ambiente com a ideia de natureza intocada tem como consequência a falsa percepção de que em ambientes densamente construídos os fenômenos naturais deixam de atuar. Assim, a cidade, como espaço resultante da ação humana sobre a natureza e como parte integrante deste grande meio constituído pelo planeta, continua a sofrer a influência dos processos naturais, a despeito dos modos de produção e da espécie humana. O desconhecimento ou a negligência a respeito desta evidência costuma ser a causa de tragédias urbanas como inundações, deslizamentos, poluição em suas diversas modalidades e uma série de outros efeitos danosos aos ecossistemas e à saúde do próprio homem.

É certo também que, numa sociedade na qual predominam as disparidades de toda a sorte, as práticas ambientalmente inadequadas nem sempre são resultado de escolhas, mas da pobreza, da ausência de opções, de políticas equivocadas e de outros fatores, que contribuem para acirrar os conflitos entre o ambiental e o social.

Outro ponto absolutamente fundamental nesta discussão, observado por Spósito (2003), refere-se à imprescindível abordagem das relações contraditórias que se instauram entre as escalas temporais da natureza e da sociedade, cujo distanciamento se amplia à medida que inovações científicas e tecnológicas são introduzidas na sociedade, acelerando cada vez mais o tempo social. Tal descompasso tende a comprometer a capacidade de reprodução e regeneração dos recursos naturais, dos quais dependem os processos produtivos.

Além do aspecto temporal, há que se mencionar o ponto de vista da complexidade das questões ambientais, entendidas como construções sociais, que envolvem inter-relações entre inúmeras variáveis cujos resultados nem sempre são previsíveis, o que só reforça o seu caráter interdisciplinar e interinstitucional.

O processo histórico que criou as condições para a fragmentação do conhecimento e sua separação em áreas distintas e específicas do saber, com o objetivo básico de potencializar a eficiência das práticas produtivas trouxe implicações não só sobre a exploração predatória dos recursos naturais ao longo do tempo, mas também sobre a dificuldade de se estabelecer uma visão integrada da 
realidade, o que torna fundamental a busca por formas de reconstrução de um conhecimento unificado, apoiadas na visão interdisciplinar.

O meio ambiente como a instância onde interagem processos de natureza física, biológica e social, só pode ser concebido a partir das relações que se estabelecem entre diferentes disciplinas, com seus respectivos saberes, que mesmo assim continuam mantendo as suas especificidades. É preciso, contudo, reconhecer que tais relações muitas vezes se instauram de forma conflituosa, visto que cada disciplina procura priorizar os seus conceitos, o que requer um diálogo constante e persistente.

Leff (2007, p.165-166) aponta os riscos de determinadas formulações a respeito da interdisciplinaridade no campo ambiental, que propõem uma visão holística e integradora do processo de desenvolvimento:

\begin{abstract}
"A interdisciplinaridade, aplicada ao campo ambiental, levou a formulações gerais que orientam uma visão holística e integradora do processo de desenvolvimento, mas deixa de fora a especificidade dos processos materiais e simbólicos que o constituem. Desta maneira, passou-se de uma concepção da complexidade como a ecologização da visão do mundo por ser a ecologia 'a ciência por excelência das inter-relações', a caracterizar o ambiente como conjuntos muito gerais de relações e agregados de processos: sociedade-natureza; população-recursos; ambiente-desenvolvimento.[...]

$\mathrm{Na}$ prática, programas concebidos sob estas categorias genéricas caem facilmente num reducionismo teórico ao adotar paradigmas pretensamente transdisciplinares para atravessar a ponte entre o natural e o social. Neste sentido, o social pode ser absorvido por enfoques ecologistas e visões biologistas, ou por um energetismo social que pretende unificar os processos biossociais em função de seus fluxos energéticos. Perdese assim de vista a especificidade dos processos materiais de ordem física, biológica, simbólica, econômica, política e tecnológica, que conformam sistemas socioambientais complexos."
\end{abstract}

Ao expor o seu ponto de vista a respeito do que vem a se constituir como interdisciplinaridade, o autor em questão descarta a possibilidade de uma abordagem que se refira "à articulação das ciências existentes, à colaboração de especialistas portadores de diferentes disciplinas e à integração de recortes selecionados da realidade, para o estudo dos sistemas socioambientais", e afirma que a interdisciplinaridade "não é um princípio epistemológico para legitimar saberes, nem uma consciência teórica para a produção científica, nem um método para a articulação de seus objetos de conhecimento. É uma prática intersubjetiva que produz uma série de efeitos sobre a aplicação dos conhecimentos das ciências e sobre a integração de um conjunto de saberes não científicos; sua eficácia provém da especificidade de cada campo disciplinar, bem como do jogo de interesse e das 
relações de poder que movem o intercâmbio subjetivo e institucionalizado do saber." (LEFF, 2007, p.168-173)

Sob o ponto de vista de Leff (2007, p.187), a globalização econômica e o discurso dominante da sustentabilidade acabaram reduzindo o conhecimento à mera função de solucionar os problemas ambientais, por meio da tecnologia e de instrumentos econômicos, desvalorizando assim os "esforços por construir um saber que integre conhecimentos e valores" e, ao mesmo tempo, dando relevância aos projetos de comunicação e informação ambiental, que buscam o discurso do consenso que, no entanto, não admite a discussão a respeito dos diversos interesses sociais envolvidos na apropriação da natureza.

Neste aspecto, torna-se preocupante a utilização cada vez mais frequente de mecanismos de caráter compensatório, por meio dos quais os danos ambientais são valorados monetariamente, transformando-se em "moeda de troca" empregada na permuta pelas mais variadas formas de contrapartida, sob uma perspectiva homogeneizante da questão. Coloca-se aqui, primeiramente, a dificuldade ou até mesmo a impossibilidade de se mensurar numericamente o valor de um dano ambiental, que geralmente redunda numa avaliação do ponto de vista meramente econômico. Além do mais, nem sempre as contrapartidas oferecidas como compensação ao dano causado resultam em benefícios de natureza ambiental, como ocorre, por exemplo, na troca pela execução de obras civis.

A prática interdisciplinar, segundo o entendimento de Floriani (2000, p.100), implica "a articulação de diversas disciplinas para melhor compreender e gerir situações de acomodação, tensão ou conflito explícito entre as necessidades, as práticas humanas e as dinâmicas naturais", só tendo sentido "com a prática social e a consequente intervenção no real". A construção do conhecimento interdisciplinar deveria esquivar-se, portanto, das abordagens reducionistas ou mesmo tendentes à busca de linguagens comuns entre as disciplinas, como pode ser verificado no trecho a seguir:

"Tal estratégia epistemológica deve buscar combater os efeitos ideológicos do reducionismo ecologista e do funcionamento sistêmico que pensam o homem e as formações sociais como populações biológicas inseridas no processo evolutivo dos ecossistemas e acreditam ser a ecologia a disciplina mais importante das inter-relações homem-natureza, elegendo-a a ciência das ciências e a verdadeira teoria geral dos sistemas". 
Considerando a coexistência de concepções diversas de termos referentes à interdisciplinaridade, Vasconcelos (2002, p.110-114) propõe uma atualização dos diferentes tipos de "práticas inter-“, baseada na classificação sugerida por Japiassu, em particular a de Jantsch (1972), segundo os graus de cooperação e coordenação entre os campos de saber. Assim, as "práticas multi-“ representariam apenas uma justaposição de diferentes áreas de saber, sem a existência de cooperação ou troca de informações, enquanto que as "práticas pluri-" se distinguiriam pela ocorrência de cooperação, mas sem coordenação, ao contrário das "práticas pluri-auxiliares", nas quais a contribuição entre um ou mais campos de saber ocorreria sob o domínio de um deles, considerado hegemônico.

A interação dos campos nas "práticas inter-" pressupõe a cooperação mútua em torno de objetivos múltiplos e da construção de axiomática comum, definida em nível hierarquicamente superior, produzindo uma redefinição dos elementos constituintes dos campos originais. Já os "campos trans-" configuram-se como uma radicalização do nível anterior, com uma coordenação compartilhada de todos os campos de saber, levando à estabilização de um campo teórico autônomo.

Para Vasconcelos (2002, p.116), os conflitos e os processos de poder nas "práticas inter-" tornam-se mais evidentes quando considerados no âmbito das profissões e das instituições, que determinam "um conjunto de estratégias de saber/poder, de competição intra e intercorporativa e de processos institucionais e socioculturais muito fortes, que impõem barreiras profundas à troca de saberes e às práticas interprofissionais colaborativas e flexíveis".

No que diz respeito às instituições públicas, as dificuldades ao desenvolvimento de práticas interdisciplinares podem ser atribuídas, em parte, à complexidade e particularidade dos aspectos de caráter institucional, legal, financeiro e de gestão envolvidos na formulação e implementação de políticas. Além disso, a atuação prática impõe uma série de dificuldades e contingências, que muitas vezes exigem providências urgentes, impossibilitando um maior aprofundamento no grau de interação interdisciplinar nas questões ambientais, sem mencionar as prioridades de ordem política.

A interinstitucionalidade, aqui compreendida como a articulação entre os diferentes órgãos e instituições da esfera pública, e eventualmente privada, visando ao encaminhamento de questões em comum, não ocorre de maneira pacífica. As 
diferentes visões a respeito do mesmo problema, os interesses diversos, as disputas de poder e as interferências de caráter político, entre outros fatores, dificultam o diálogo, muitas vezes entre diferentes setores de uma mesma instituição, ocasionando inclusive o desenvolvimento de atividades paralelas sobre o mesmo tema. Esta dificuldade torna-se ainda maior quando se trata do entendimento entre organizações distintas, ou quando a interação ocorre mediante o envolvimento de outros atores sociais externos a elas.

Um dado fundamental no campo do trabalho interdisciplinar desenvolvido no âmbito institucional, especialmente na esfera das organizações públicas, diz respeito ao aspecto temporal, visto que as atividades desta natureza geralmente exigem um tempo maior para a sua concepção, maturação e implementação, aspecto invariavelmente incompatível com a necessidade política, que exige tempos de retorno extremamente rápidos, resultando em trabalhos com pouca consistência, pouco duradouros e sem a efetiva utilização pela população.

Diante da existência de campos do conhecimento bastante consolidados e de práticas institucionais e organizacionais já há muito estabelecidas, a construção de um trabalho interdisciplinar, nos termos defendidos por Leff e Floriani, constitui uma missão excepcionalmente complexa, mas que deve ser constantemente perseguida, principalmente no âmbito do serviço público, pois a implementação de trabalhos sólidos e permanentes surgem em decorrência do exercício da interdisciplinaridade e da interinstitucionalidade, com base em procedimentos e decisões previamente pactuados.

\subsection{As Áreas Contaminadas no contexto da sustentabilidade e da interdisciplinaridade}

A problemática das áreas contaminadas evidencia de forma muito clara a relação conflituosa entre o social e o natural, particularmente nas áreas urbanas, pois envolve o encadeamento de uma série de fenômenos físicos, químicos e biológicos produzidos a partir da realização de atividades humanas, e eventualmente naturais, que geram efeitos sobre o meio ambiente e à população.

As consequências mais perceptíveis da contaminação manifestam-se sob a forma de danos aos ecossistemas naturais e prejuízos à saúde humana e, quando o problema é ignorado ou não é tratado com a abrangência que o assunto requer, 
corre-se o risco de se ter uma compreensão distorcida do que realmente ocorre e de se verem repetidos os resultados desastrosos de inúmeros casos já conhecidos. Mesmo assim, o tratamento que vem sendo dispensado ao tema, sobretudo pelo poder público, ainda se restringe ao aspecto puramente técnico, encarado apenas do ponto de vista do controle das fontes de poluição, isto é, sob um enfoque bastante importante, porém parcial da matéria.

É inquestionável a natureza interdisciplinar do tema das áreas contaminadas, uma vez que para a compreensão da sua gênese e dos fenômenos naturais ali envolvidos, assim como para a proposição de formas de gestão do problema, é imprescindível que se tenha a real percepção das interações que ocorrem entre as diferentes áreas do conhecimento envolvidas, assim como dos diferentes agentes e grupos sociais que atuam na construção do espaço urbano.

A Companhia Ambiental do Estado de São Paulo (CETESB) define gerenciamento de áreas contaminadas como o "conjunto de medidas tomadas com o intuito de minimizar o risco proveniente da existência de áreas contaminadas, à população e ao meio ambiente". No plano institucional, a sua concepção e implementação diluem-se pelos diferentes níveis de governo, de acordo com as respectivas atribuições e competências específicas.

A atuação isolada de cada instância de poder dificulta, por vezes impedindo a realização de ações conjuntas e, na medida em que não existe uma tradição de práticas de trabalhos integrados na administração pública, raramente se avalia a compatibilidade entre as ações promovidas por organizações governamentais distintas. No gerenciamento de áreas contaminadas, o trabalho interinstitucional é um fator de fundamental importância, pois este é um campo que envolve uma série de procedimentos, que se distribuem por diferentes organismos, num quadro de extrema fragmentação que caracteriza a estrutura administrativa brasileira. A estas dificuldades de ordem institucional, ainda se somam os obstáculos de caráter político, que variam conforme as prioridades de cada administrador.

A reutilização crescente de terrenos com potencial de contaminação do solo em áreas urbanas, especialmente pelo mercado imobiliário, reforça a necessidade premente da formulação de políticas públicas direcionadas ao tema, fundamentadas numa visão total e não fragmentada da questão, o que, sem dúvida, requer uma 
atuação efetiva do poder público, bem como a sua interação com os diversos interlocutores e interesses envolvidos.

Sem dúvida, a concepção dominante da ideia de sustentabilidade, que preconiza o crescimento econômico contínuo, com base nos mecanismos de mercado e nas soluções técnicas, está muito distante do real sentido do termo, principalmente pelo fato de não estabelecer limites à superexploração dos recursos naturais, além de considerar a técnica como o antídoto para todos os problemas advindos de tal prática.

É inevitável, portanto, reconhecer as limitações para se tratar do tema nas condições estabelecidas por uma racionalidade econômica que se fundamenta na maximização do lucro e do excedente econômico no curto prazo. No entanto, é preciso admitir que o mercado também impõe transformações ao espaço urbano numa velocidade extraordinária, o que exige a formulação de políticas públicas que enfrentem a questão com a mesma celeridade, disciplinando as formas de ocupação deste espaço, principalmente nas situações em que os danos ambientais tenham consequências sobre os ecossistemas e a saúde pública.

\subsection{A cidade de São Paulo como cenário de conflitos na construção da paisagem pós-industrial}

O embate entre o social, o econômico e o ambiental manifesta-se de forma mais intensa nas cidades, principalmente nos grandes centros urbanos, onde as intervenções das atividades humanas sobre o meio físico ocorrem de modo extremamente impactante, assumindo contornos dramáticos em muitas situações, como se constata ao longo do tempo na cidade de São Paulo.

Historicamente moldada ao sabor das conveniências do capital e dos interesses imobiliários, a cidade passa a assistir a um processo de modificação gradual de seu sítio urbano, acima de tudo a partir das transformações econômicas promovidas pela expansão da cultura cafeeira, que gera os excedentes utilizados no custeio de significativa parcela da produção industrial inicial e da infraestrutura de suporte a esta atividade, em especial da rede de transportes para o escoamento da produção. Naquele momento a ferrovia exerceu papel fundamental, com a implantação da primeira linha ligando Santos a Jundiaí, em 1867, o que possibilitou a conexão entre as zonas produtoras de café e o porto, além de estimular o 
crescimento da cidade de São Paulo como centro financeiro, comercial e administrativo.

A topografia plana e o baixo preço da terra, por se tratarem de terrenos inundáveis e insalubres, foram fatores determinantes para o assentamento das ferrovias sobre as várzeas dos principais rios da cidade. Aproveitando as condições favoráveis e as vantagens locacionais, configurados no trinômio ferrovia, terreno grande e plano e curso d'água, citado por Langenbuch (1971), teve início o processo de ocupação das margens dos rios por atividades industriais e correlatas, que deu origem a bairros como Brás, Bom Retiro, Mooca, Água Branca, Lapa e Ipiranga. Tal padrão de apropriação do espaço teria consequências futuras sob a forma de alagamentos e problemas de drenagem e, mais recentemente, da descoberta de áreas com contaminação do solo e das águas subterrâneas.

A respeito das intervenções nas várzeas dos dois mais importantes rios da cidade, Tietê e Pinheiros, a tese de Seabra (1987, p.112) é bastante esclarecedora, ao demonstrar os diversos interesses que concorreram para a retificação de ambos os cursos d'água, ao que a autora se refere como "processo de transformação da 'natureza natural' dos rios", que praticamente definiu a atual conformação da cidade nessas áreas. A retificação envolveu, acima de tudo, a questão da valorização das terras imediatamente beneficiadas pelas obras, situadas na várzea, como daquelas adjacentes, além da apropriação dos investimentos públicos pelos agentes privados.

Infere-se dos estudos de Seabra (1987) que, no caso do Tietê, as obras de retificação estavam, até um determinado período, prioritariamente relacionadas à necessidade de equacionar o problema das cheias com o aumento da capacidade de escoamento do rio.

A proposta de intervenção para o Tietê, elaborada sob a orientação de Saturnino de Brito, por ocasião da criação da Comissão de Melhoramento do Rio Tietê em 1923, apresentava estudos para a regularização do traçado do rio, que acompanhava o seu curso natural, associada à implantação de um grande parque linear e à preservação de áreas permeáveis ao longo da várzea. Lamentavelmente, esta alternativa acabou sendo preterida em favor da retificação do traçado do rio, que reduziu o seu percurso e liberou as suas margens para usos urbanos, tendo como consequência imediata, segundo o estudo de Seabra (1987), a apropriação da 
valorização decorrente de um grandioso investimento de caráter social realizado pela municipalidade, por parte dos proprietários das áreas ribeirinhas.

$\mathrm{Na}$ década de 60, o assoreamento do leito do Tietê surgia como um dos maiores problemas para a administração pública, em decorrência da crescente urbanização e impermeabilização das bacias, situação que só se agravou com o passar do tempo.

Diferentemente do Tietê, Seabra (1987) demonstra que a retificação do rio Pinheiros estava intimamente relacionado aos programas de produção de energia, fator essencial para o desenvolvimento industrial. Assim, na década de 20, o Grupo Light inicia suas investidas para o aproveitamento das águas do Tietê, com a reversão do curso do Pinheiros e a formação de um reservatório no planalto, para a geração de energia em uma usina na baixada santista, o que se concretizou com a edição da Lei $n^{\circ}$ 2.249, de 27 de dezembro de 1927, que atribuiu à empresa o direito de desapropriação dos terrenos e outros bens considerados indispensáveis à construção de todas as obras, declarados de utilidade pública, bem como as áreas alagadiças ou sujeitas a inundações, saneadas ou beneficiadas em função dos serviços previstos pela referida lei, declaradas de necessidade pública. O exercício do direito de desapropriação ficaria, neste caso, submetido à prévia aprovação das plantas das obras pelo Poder Executivo, embora a lei não fizesse qualquer distinção entre utilidade pública e necessidade pública e não estabelecesse critérios para a definição do que seriam zonas inundáveis.

O golpe final, após a retificação dos rios Tietê e Pinheiros, ainda estaria por vir com a implantação das vias marginais e a transformação dos leitos dos rios em canais de esgoto a céu aberto, isolando-os definitivamente do convívio com os habitantes da cidade, ensejando, inclusive propostas para o seu tamponamento, como acabou acontecendo parcialmente em outro rio significativo para a história da cidade, o Tamanduateí.

No processo de urbanização das várzeas da cidade, grande parte dos córregos que deveriam contribuir para o sistema de drenagem da cidade passaram a ser canalizados a partir do século XIX, em muitos casos confinados em tubulações que se tornaram insuficientes em razão da crescente impermeabilização do solo urbano. Os córregos ocultos da cidade hoje percorrem regiões totalmente ocupadas e urbanizadas, deixando pouquíssimos vestígios de sua existência, a não ser pelos 
efeitos que ainda produzem sobre o cotidiano dos habitantes, como demonstra a pesquisa desenvolvida pelo professor Bartalini (2004) da Faculdade de Arquitetura e Urbanismo da Universidade de São Paulo.

A ocupação das margens dos cursos d'água na cidade evidencia um padrão usual de implantação no qual os lotes lhes dão as costas, como se houvesse a intenção de encobrir um elemento estranho ao meio urbano, fonte de transtornos, cuja principal função seria a de transportar os dejetos produzidos pelos moradores da cidade. Como agravante, a prática da canalização dos cursos d'água pelo próprio poder público, difundida como solução para as enchentes e reforçada pelos discursos políticos, certamente contribuiu para consolidar na população a ideia de que tal procedimento seria o mais adequado para sanar o problema.

As transformações ocorridas na cidade, durante a primeira metade do século $X X$, e as consequentes alterações na paisagem urbana só reafirmam a existência de um processo contínuo de apropriação da natureza pelo homem, que aqui se instala a partir do período colonial e se caracteriza pela exploração predatória dos recursos naturais, de acordo com as necessidades do modo de produção e de sua reprodução, incorporando as especificidades e os interesses inerentes a cada período histórico.

Se esse processo estava inicialmente relacionado basicamente às demandas mercantis da Metrópole, ainda sob o olhar estrangeiro diante de uma natureza exuberante e desconhecida, a presença do colonizador numa terra ainda inexplorada e habitada por nativos significou também a inserção de um universo completamente estranho sobre um suporte físico, ambiental e social estabelecido e absolutamente diverso, o que ao longo do tempo representou o rompimento das relações sociais existentes e a dilapidação da natureza, para a imposição de um estrutura sócio-política hegemônica, baseada no modelo de produção instituído pelo colonizador.

Em contrapartida, a atividade industrial, atrelada à existência do capital, introduziu uma série de modificações substanciais nos padrões de produção e consumo, ao mesmo tempo em que produziu a separação entre campo e cidade, passando esta a assumir um papel fundamental no processo produtivo. 
A forma de ocupação dos espaços urbanos mantém um estreito vínculo com a natureza, na medida em que se utiliza dela como base física, estabelecendo-se aí uma dualidade na qual o conflito é um elemento constante, que surge em decorrência da maneira como o modo de produção se organiza e define a configuração dos objetos no espaço.

A visão utilitária de natureza como algo estático, constituído de elementos à disposição da ação humana e do capital para a produção de objetos técnicos, carregados de valores e essenciais à sobrevivência do homem, acaba conduzindo ao desaparecimento da distinção entre o que é natural e o que é artificial, assim como da noção de que os fenômenos naturais continuam a atuar, mesmo no meio urbano. Neste sentido, o caso da canalização de cursos d'água e da ocupação das áreas de várzeas na cidade de São Paulo é exemplar e demonstra que decisões equivocadas tomadas no passado podem legar situações problemáticas ao conjunto da sociedade e ao próprio processo produtivo, muitas vezes exigindo soluções economicamente dispendiosas ou inviáveis, e até mesmo tecnicamente inexequíveis. O mesmo se pode dizer em relação à poluição das águas como consequência do contínuo despejo de dejetos domésticos e industriais, transformando-os em canais de esgoto, impedindo não só a sua utilização como espaços de convivência, fruição e lazer, mas também o estabelecimento de uma maior relação de proximidade com a população da cidade, fato agravado pela construção de vias para a circulação de veículos em suas margens.

Num período mais recente, um dos principais campos de conflito na esfera ambiental urbana tem sido a questão dos assentamentos precários em áreas ambientalmente frágeis e legalmente protegidas, ou em situações de risco.

A disputa por territórios privilegiados na cidade entre diferentes grupos sociais, com interesses diversos e poderes de influência desiguais, aliada à falta de políticas efetivas de provimento de habitações de interesse social, impôs como única alternativa de moradia às camadas economicamente menos favorecidas da população os assentamentos irregulares, construídos de forma precária e insalubre, à margem da legislação urbanística, que proliferaram pela cidade, invariavelmente sobre terrenos inadequados do ponto de vista ambiental.

Refinetti (2006) destaca as consequências da aprovação da Lei Estadual de Proteção aos Mananciais, de 1975, para as bacias das represas Billings e 
Guarapiranga, com a proliferação de inúmeros loteamentos irregulares sem grandes preocupações quanto à regularidade urbanística, legal e ambiental.

É oportuno lembrar que a afirmação recorrente de que a pobreza seria uma das principais causas da degradação ambiental parece tendenciosa, na medida em que populações de alta renda também contribuem para a deterioração dos recursos naturais e, neste caso, o que deveria ser questionado seriam os fatores que levam à geração de abismos sociais e que acabam privando determinados setores da sociedade do acesso às condições mínimas de habitação e bem-estar.

Numa cidade construída predominantemente por influência dos interesses imobiliários, cuja base física foi sendo profundamente alterada ao sabor dos desígnios econômicos, as estratégias do mercado têm se utilizado com frequência de argumentos ambientalistas e de imagens relacionadas à proximidade do verde, para demonstrar as vantagens locacionais de empreendimentos imobiliários (Foto 1 e Figura 3).

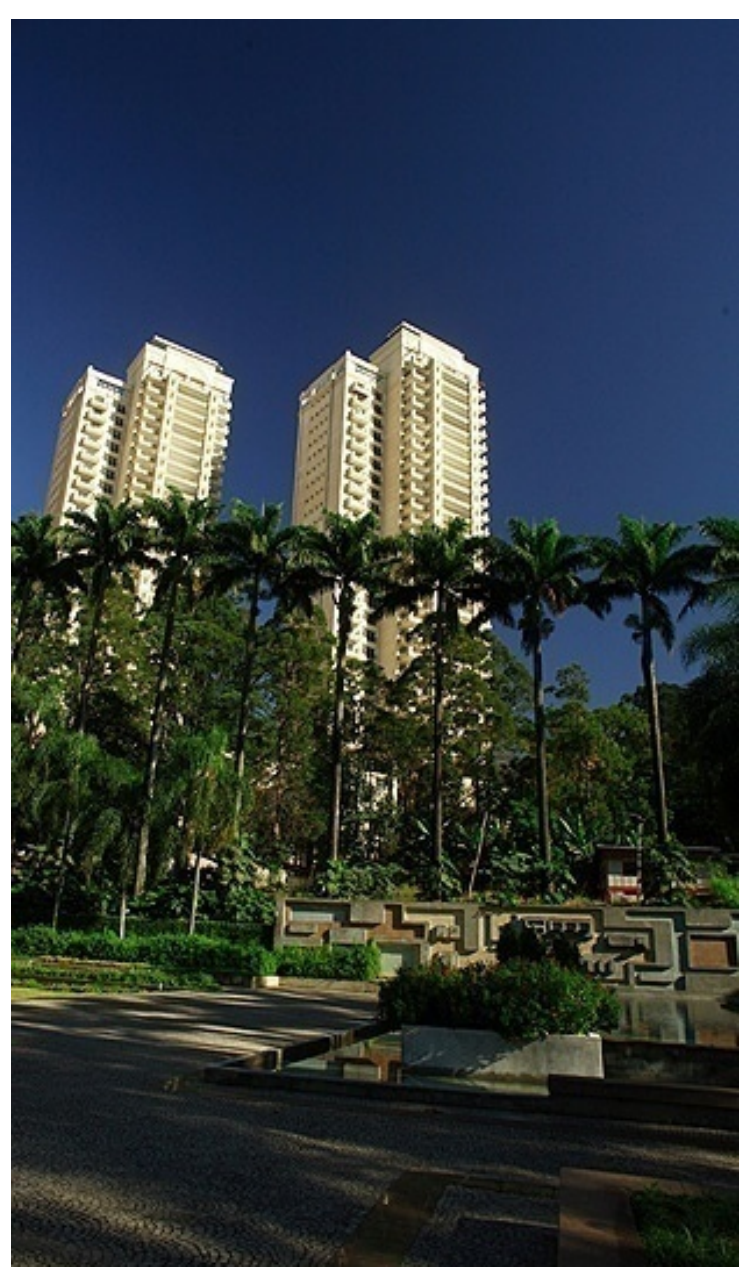

Foto 1 - Edifícios no entorno do Parque Burle Marx Fonte: cyrela.com.br 


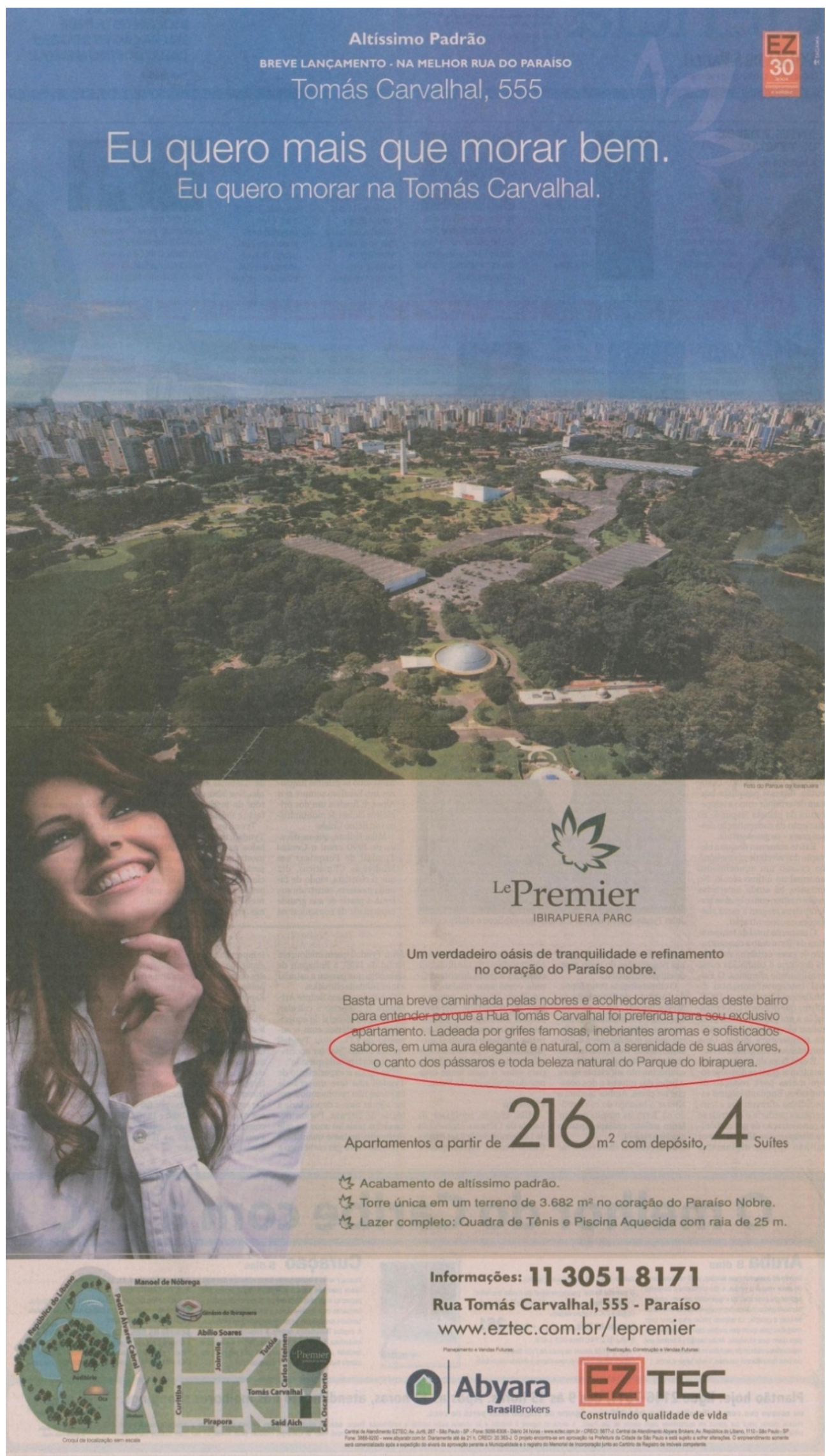

Figura 1 - Anúncio publicitário para empreendimento imobiliário, destacando a sua proximidade com o Parque Ibirapuera

Fonte: Folha de São Paulo - 21/06/2009 
A impetuosidade do mercado imobiliário pela apropriação de novas áreas na cidade, para a implantação de seus empreendimentos, continua a ignorar as limitações impostas pelas condições ambientais e geográficas do território, mesmo porque em muitas situações a própria legislação não oferece restrições à sua ocupação.

É neste contexto que a cidade de São Paulo assiste à transformação de suas antigas áreas industriais, a partir de um movimento global observado já na década de 1970, quando se intensifica o processo de expansão do capital, com a reorganização das estruturas produtivas e das formas gerenciais das empresas, que passam a procurar as condições necessárias à flexibilização da atuação no território, inclusive no nível internacional.

A extraordinária evolução tecnológica observada nas últimas décadas, notadamente nos campos da comunicação e da informática, vem possibilitando a difusão e a troca de informações com uma rapidez cada vez maior, fator que aliado ao desenvolvimento dos sistemas de transporte e às vantagens locacionais, facilita a ocupação de regiões mais periféricas e induz à transformação de áreas já consolidadas, dando ensejo à ampliação da especialização do trabalho nos lugares. Sobre essa questão, Santos (2003, p. 93) observa que o território "é usado a partir de seus acréscimos de ciência e técnica", o que o configura como "um novo meio geográfico", onde a informação surge como um recurso distribuído de maneira desigual.

A fluidez do espaço, favorecida pelo desenvolvimento técnico, científico e informacional, permite a disseminação das atividades econômicas para diferentes pontos do território nacional, intensificando a divisão social e territorial do trabalho. Ao mesmo tempo atende aos requisitos de um mercado global estreitamente interligado, por meio do estabelecimento de uma densa e complexa rede logística, que prioriza determinadas regiões estratégicas, num movimento inconstante de busca dos lugares que melhor satisfaçam as necessidades produtivas das organizações corporativas, processo que contribui para criar situações de incerteza.

Este processo impõe alterações nas atividades econômicas locais e provoca significativas mudanças nas estruturas de produção, nos modos de circulação e no uso do solo na cidade, o que implica a readequação do espaço às novas 
necessidades, envolvendo altos custos para a sociedade no intuito de atender às demandas momentâneas do capital.

Em artigo sobre a maneira como os mecanismos econômicos predominantes do capitalismo, caracterizados pela "hipermobilidade" dos fluxos, afetam os lugares e as pessoas, Vaccaro (2006) analisa as transformações radicais de áreas periféricas em várias partes do mundo provocadas pela rápida industrialização, assim como o seu ainda mais rápido processo de abandono, quando há a cessação desta atividade. O que o autor denomina de modernidade pós-industrial distingue-se pelo alto grau de incerteza, risco e vulnerabilidade aos quais diversas localidades são submetidas, como consequência da transição de uma posição de centralidade no mercado global para um retorno à situação periférica, num contínuo processo de transformação.

Essa nova forma de modernidade, segundo Vaccaro (2006), envolve também um complexo e crescente processo de urbanização do mundo, cujas necessidades direcionam a hipermobilidade do capital e das mercadorias, facilitando a devastação ambiental e social. Mesmo as áreas rurais periféricas focadas pelo autor não deixam de estar conectadas à extensa rede de produção e consumo, dentro de padrões de vida ajustados à modernidade, tornando a divisão entre rural e urbano um mito. Sobre este tema, Santos (2003) ainda observa que o território de um país pode tornar-se um espaço nacional da economia internacional, visto que, embora o espaço e a regulação sejam nacionais, a economia é orientada pelos interesses das empresas multinacionais.

A perda da função produtiva tem consequências profundas sobre a organização social, especialmente quando a economia local está estruturada sobre uma atividade produtiva específica. A estagnação econômica, acompanhada por um processo de desintegração social e de esvaziamento populacional, que se segue ao desaparecimento da atividade industrial, resulta não só no abandono de edificações e instalações que atendiam à atividade industrial, mas também daquelas que exerciam funções complementares a ela, transformando espaços anteriormente absorvidos por funções atribuídas pelas atividades produtivas em espaços desabitados ou invadidos, praticamente desprovidos da atuação do poder público.

A respeito da concepção de espaço, Santos (1997) o classifica como uma instância da sociedade, que contém e é contido pelas demais instâncias sociais, 
quais sejam a econômica e a cultural-ideológica. A paisagem apresenta-se, assim, como o conjunto de objetos geográficos dispostos sobre um território, sua configuração geográfica ou espacial específica e o modo como eles são visualizados pelos olhos, que somente se efetiva como espaço com os processos sociais representativos de uma sociedade, num determinado momento, os quais, por sua vez, se materializam por meio de formas. Cada forma surgiria "como resposta a certas necessidades ou funções do presente", embora permaneça a coexistência de formas novas e antigas, visto que também ocorre a adaptação de velhas formas criadas no passado às funções exigidas pelo momento atual. A paisagem consiste, portanto, numa sobreposição de camadas de formas originadas em diferentes períodos, que se integram ao sistema social existente.

Um dos exemplos mais representativos dos efeitos decorrentes da perda das funções produtivas está na cidade norte-americana de Detroit, outrora símbolo do poderio industrial e sede das principais empresas do setor automobilístico mundial. O processo de transformação da cidade teve início ainda na década de 1960, com o abandono de sua área central pela classe média, em razão do aumento da violência provocada por conflitos gerados a partir de um brutal movimento de segregação racial, agravando-se com o declínio da indústria automobilística americana nos anos 80 e a perda de milhares de postos de trabalho. A população do município de Detroit, que era de 1,85 milhão, não parou de decair até chegar aos cerca de 850 mil habitantes atuais, deixando uma enorme área vazia de $130 \mathrm{~km}^{2}$, correspondente a cerca de um terço da área total da cidade (Fotos 2 a 5).

A atual administração municipal vem trabalhando com a proposta de utilizar verbas federais para remover moradores de regiões mais esvaziadas para outras ainda economicamente ativas, transformando-as em áreas verdes ou produtoras de frutas e vegetais. Apesar da resistência à ideia por parte de muitos dos antigos residentes, a prefeitura não descarta o corte do provimento de serviços essenciais nessas áreas como forma de coagir a população a aderir ao projeto. 


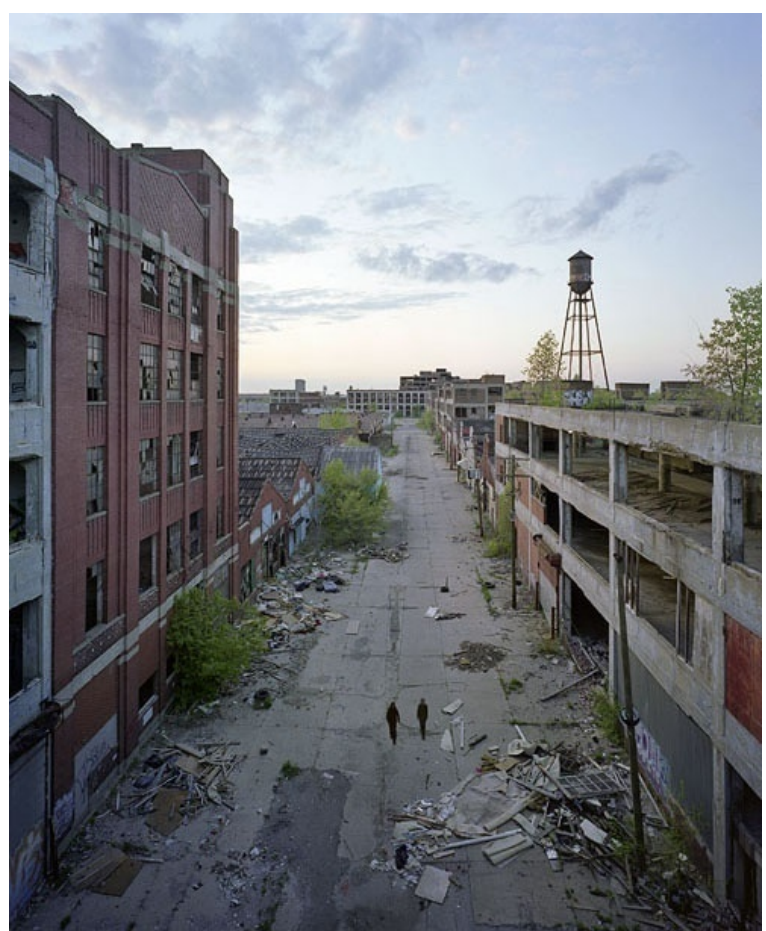

Foto 2 - Indústria Packard Motors

Fonte: www.marchandmeffre.com

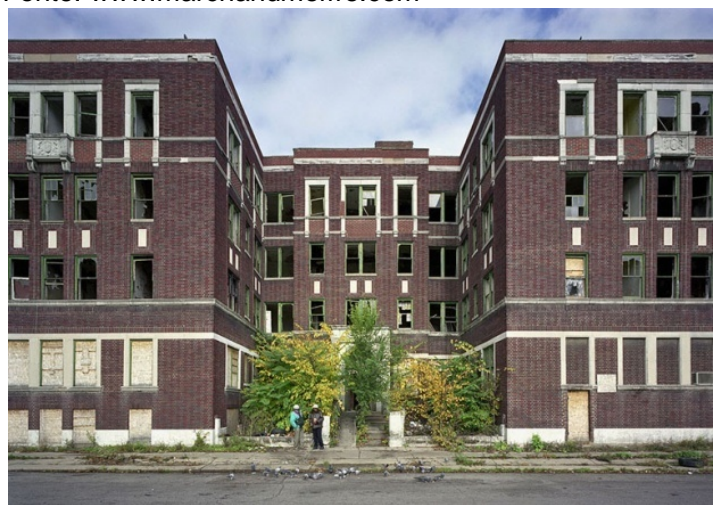

Foto 4 - Rich-Dex Apartments

Fonte: www.marchandmeffre.com

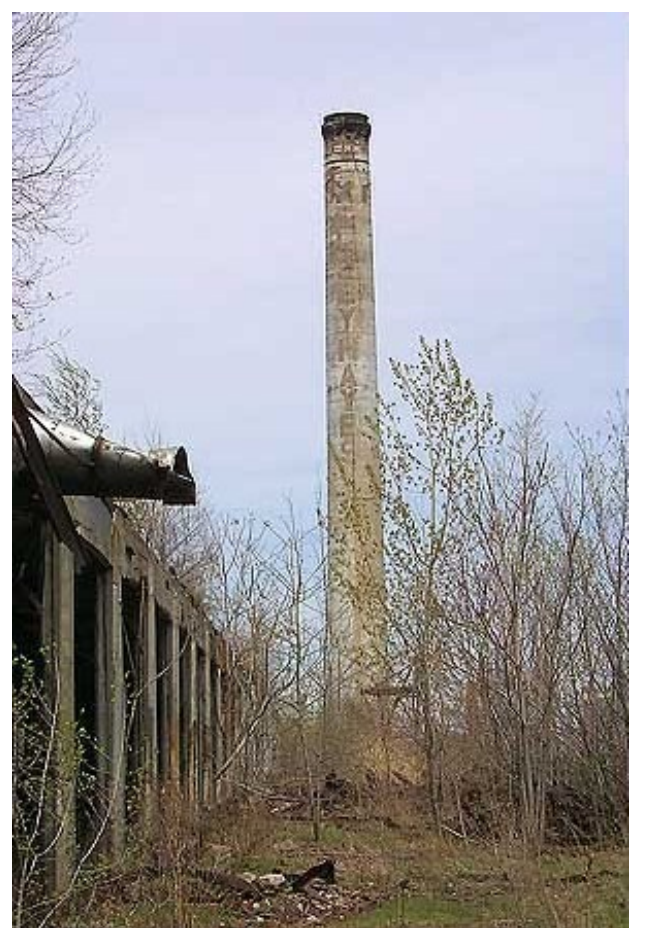

Foto 3 - Indústria de rodas Kelsey Hayes Fonte: www.detroityes.com

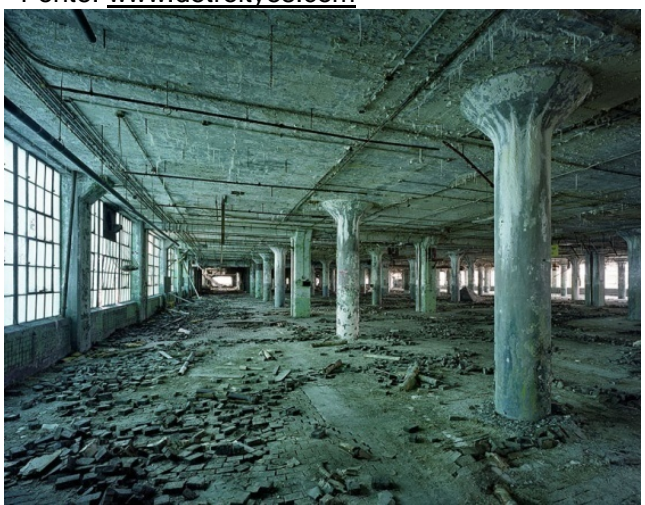

Foto 5 - Indústria de Peças Automotivas Fisher Body

Fonte: www.marchandmeffre.com

O vale do rio Emscher, afluente do rio Reno, na Alemanha, constitui outro exemplo significativo de paisagem pós-industrial resultante do declínio da atividade produtiva, neste caso baseada na predominância dos setores da mineração e da metalurgia. Alves (2003) demonstra que a herança deixada, após anos de degradação ambiental, materializou-se sob a forma de cursos d'água poluídos, solo contaminado, elevado nível de emissões de poluentes tóxicos, além de velhas indústrias, minas abandonadas e montanhas de resíduos industriais. A exemplo de Detroit, em algumas cidades do vale, as antigas edificações e estruturas abandonadas formavam grandes vazios urbanos em áreas centrais.

A planície por onde correm o rio Emscher e os seus tributários é uma região intensamente ocupada e densamente povoada, sendo que a proximidade entre as 
cidades favoreceu a formação de uma grande conurbação. O seu projeto de recuperação ambiental e urbana foi concebido no contexto da IBA (Internationale Bauausstellung - Exposição Internacional de Construção) - Emscher Park, criada a partir de 1989, por um período inicial de dez anos, que repete a tradição alemã das exposições de construção, como a que ocorreu em Berlim nos anos 80. Tais exposições não constituem eventos de exibição nos moldes tradicionais, mas em programas de ações para promover transformações de alcance regional. No caso do Emscher Park, o foco é abrangente e não se restringe apenas à questão das edificações, mas estende-se aos aspectos mais amplos que envolvem a recuperação socioeconômica, urbanística, paisagística e ambiental daquele território.

Em Duisburg-Meiderich encontra-se um dos empreendimentos mais significativos desse programa de transformação regional. Trata-se do Landschaftspark, um gigantesco parque público de lazer num terreno de 230 hectares, que ocupa as antigas instalações da siderúrgica Thyssen, desativadas no ano de 1985 (Foto 6).

O projeto do parque, concebido pelo arquiteto paisagista Peter Latz, vencedor de um concurso público internacional, procurou integrar fragmentos remanescentes da paisagem pós-industrial, incorporando elementos históricos, naturais, culturais e recreativos. Mesmo depois de sua abertura em 1994, outras estruturas existentes receberam novos usos e foram sendo agregadas ao parque, algumas delas após sofrerem processo de remediação da contaminação (Fotos 7 e 8). 


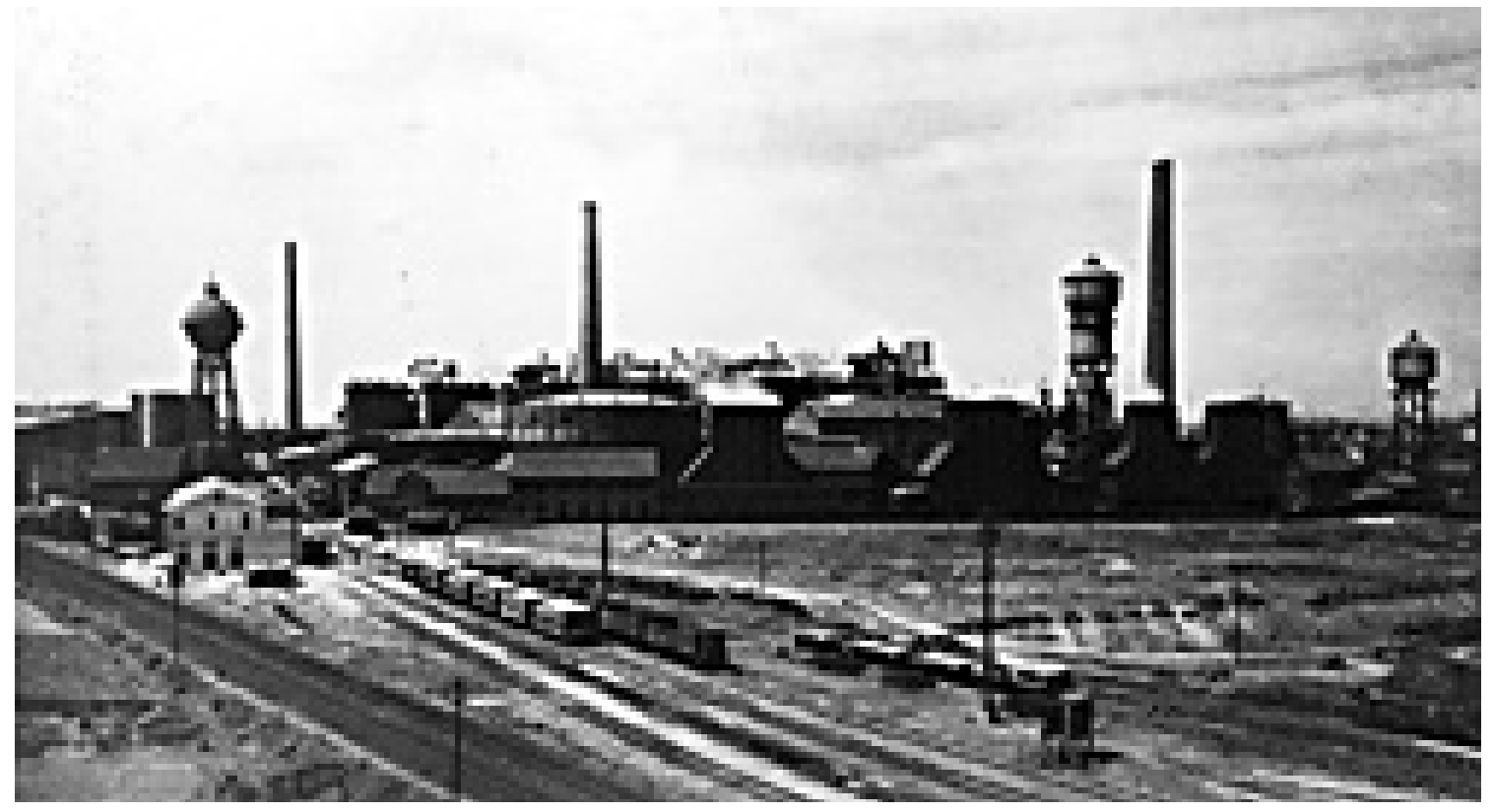

Foto 6 - Vista das instalações da antiga siderúrgica Thyssen

Fonte: Landschaftspark Duisburg-Nord $\mathrm{GmbH}$

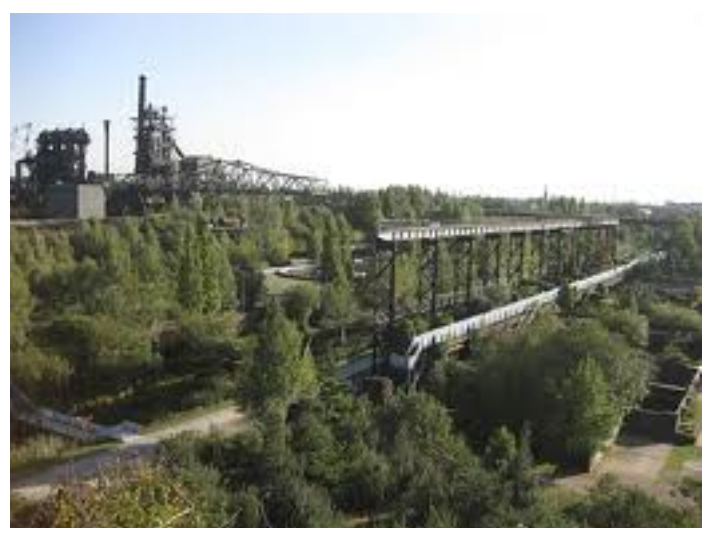

Foto 7 - Vista geral do Landschaftspark

Fonte: Landschaftspark Duisburg-Nord GmbH

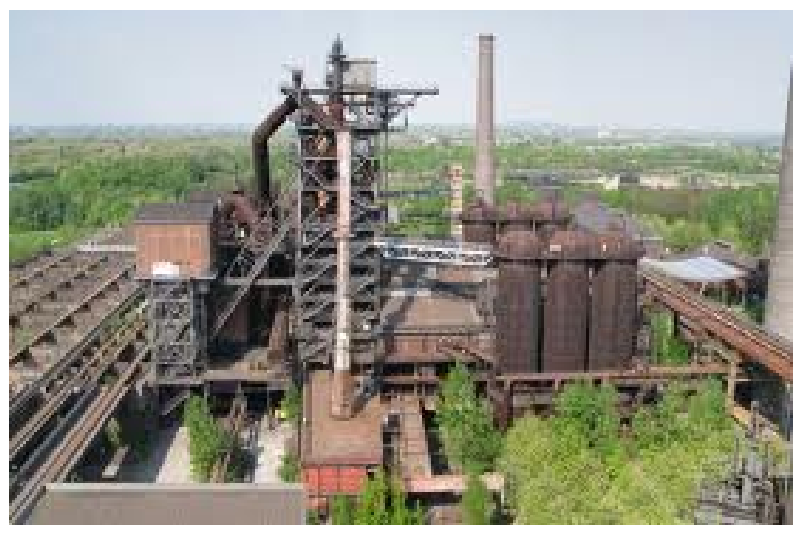

Foto 8 - Vista geral do Landschaftspark

Fonte: Landschaftspark Duisburg-Nord GmbH

A paisagem e o espaço de um determinado território revelam, portanto, o processo histórico percorrido por um determinado território, identificado nos elementos que os compõem, os quais, de acordo com Leite (2003, p.434), constituem objetos qualificados que se articulam no território, adquirindo um valor relativo no espaço e estabelecendo relações específicas nos lugares. Ressalta, ainda, que o que confere qualificação a esses objetos é o próprio uso que a sociedade faz deles, atribuindo-Ihes um conteúdo cultural que os transforma em "veículos de transmissão de práticas sociais". Dessa forma, o conjunto formado por tais objetos configura-se como formas da paisagem que, na realidade, não se 
apresentam como produtos acabados de um processo, mas como algo em constante transformação.

Nesse processo de contínua transformação do espaço urbano, a reocupação de antigas áreas industriais, promovida principalmente pelos interesses do setor imobiliário, resultam muitas vezes em paisagens constituídas por objetos não qualificados, produzidos à custa da destruição do patrimônio ambiental, histórico e arquitetônico.

A paisagem, como depositária de formas de tempos passados, também pode ocultar problemas herdados de atividades exercidas anteriormente e que ainda podem produzir efeitos no presente, e eventualmente no futuro, como a contaminação do solo e das águas subterrâneas, especialmente por se tratar de um tipo de poluição que se caracteriza pela pouca visibilidade e capacidade de persistência no ambiente.

$\mathrm{Na}$ cidade de São Paulo, a conversão de usos de terrenos que abrigaram atividades fabris em tradicionais redutos industriais, como Mooca, Ipiranga, Vila Leopoldina, Barra Funda e Santo Amaro fica evidenciada nas rápidas transformações da paisagem, que decorrem da reutilização e adaptação das edificações existentes, ou da sua demolição e posterior implantação de novos empreendimentos residenciais e comerciais, geralmente constituídos por condomínios formados por conjuntos de imensas torres que contrastam com a ocupação horizontal do entorno. Muitos desses terrenos apresentam potencial de contaminação do solo e das águas subterrâneas em razão das atividades lá exercidas no passado, fato que de um lado pode representar um problema, quando os procedimentos adequados para o seu reúso não são adotados, mas que de outro lado pode significar uma oportunidade para a requalificação e a reapropriação de espaços urbanos que poderiam permanecer fadados ao abandono físico e social, uma vez que a simples presença da contaminação não constitui um fator impeditivo à reutilização de tais áreas. 


\section{Capítulo 2}

\section{As áreas contaminadas no contexto de uma abordagem fragmentada na cidade de São Paulo}

\subsection{A atuação fragmentada do poder público municipal nas questões ambientais}

A crescente compartimentação do conhecimento e das áreas de atuação das atividades humanas torna-se presente de uma forma cada vez mais efetiva nas estruturas do poder público, formando nichos estaques de poder que acabam atuando com relativa independência. Tal situação vem ao encontro de outra tendência que se verifica com frequência na política brasileira, que diz respeito à necessidade da criação de cargos para serem compartilhados entre aliados daqueles que se encontram momentaneamente exercendo o poder.

Se por um lado este quadro atende aos interesses de uma acomodação política, do ponto de vista da gestão da cidade ela é desastrosa, na medida em que os problemas e as suas pretensas soluções são considerados de maneira totalmente parcial, tendo em vista os interesses e as necessidades de cada setor, em um dado momento.

$\mathrm{Na}$ cidade de São Paulo, por exemplo, os problemas de alagamentos estão diretamente relacionados às formas inadequadas de ocupação do espaço ao longo do tempo, sobre uma região dominada pelas várzeas de três rios e abundante em cabeceiras, situação agravada pela progressiva impermeabilização do solo, o que resultou na deterioração das condições apropriadas de funcionamento do sistema natural de drenagem urbana.

Considere-se o caso dos Centros Educacionais Unificados (CEUs), complexos educacionais, esportivos e culturais integrados, originalmente concebidos por técnicos do Departamento de Edificações, da Secretaria de Serviços e Obras da Prefeitura de São Paulo. Um dos principais obstáculos enfrentados, diante da decisão política de implantá-los, foi o de encontrar áreas com o tamanho compatível para edificá-los. Em que pese a importância que tais equipamentos adquiriram para as comunidades nas quais estão inseridos, vários deles foram construídos em áreas de preservação permanente, alguns deles literalmente sobre o leito de córregos, como os CEUs Butantã e Feitiço da Vila (Fotos 9 e 10). Enquanto isso o CEU Paz, 
construído sobre uma encosta íngreme tomada por habitações precárias, localizada nas franjas da Serra da Cantareira, acabou induzindo a ocupação no seu entorno, numa região extremamente frágil do ponto de vista ambiental (Fotos 11 e 12).



Foto 9 - Foto aérea do CEU - Butantã

Fonte: Google Earth - imagens 2009

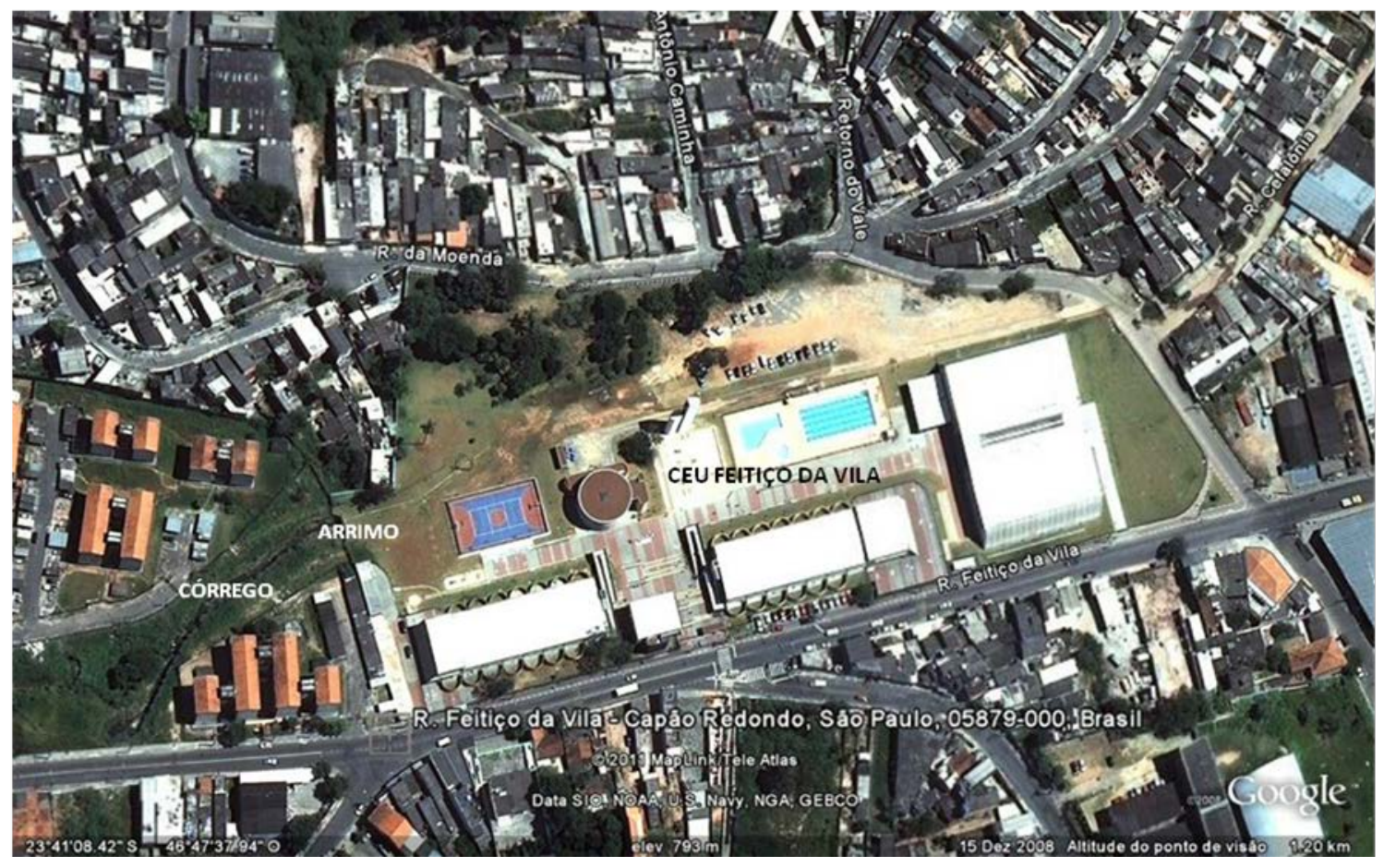

Foto 10 - Foto aérea do CEU - Feitiço da Vila

Fonte: Google Earth - imagens 2009 


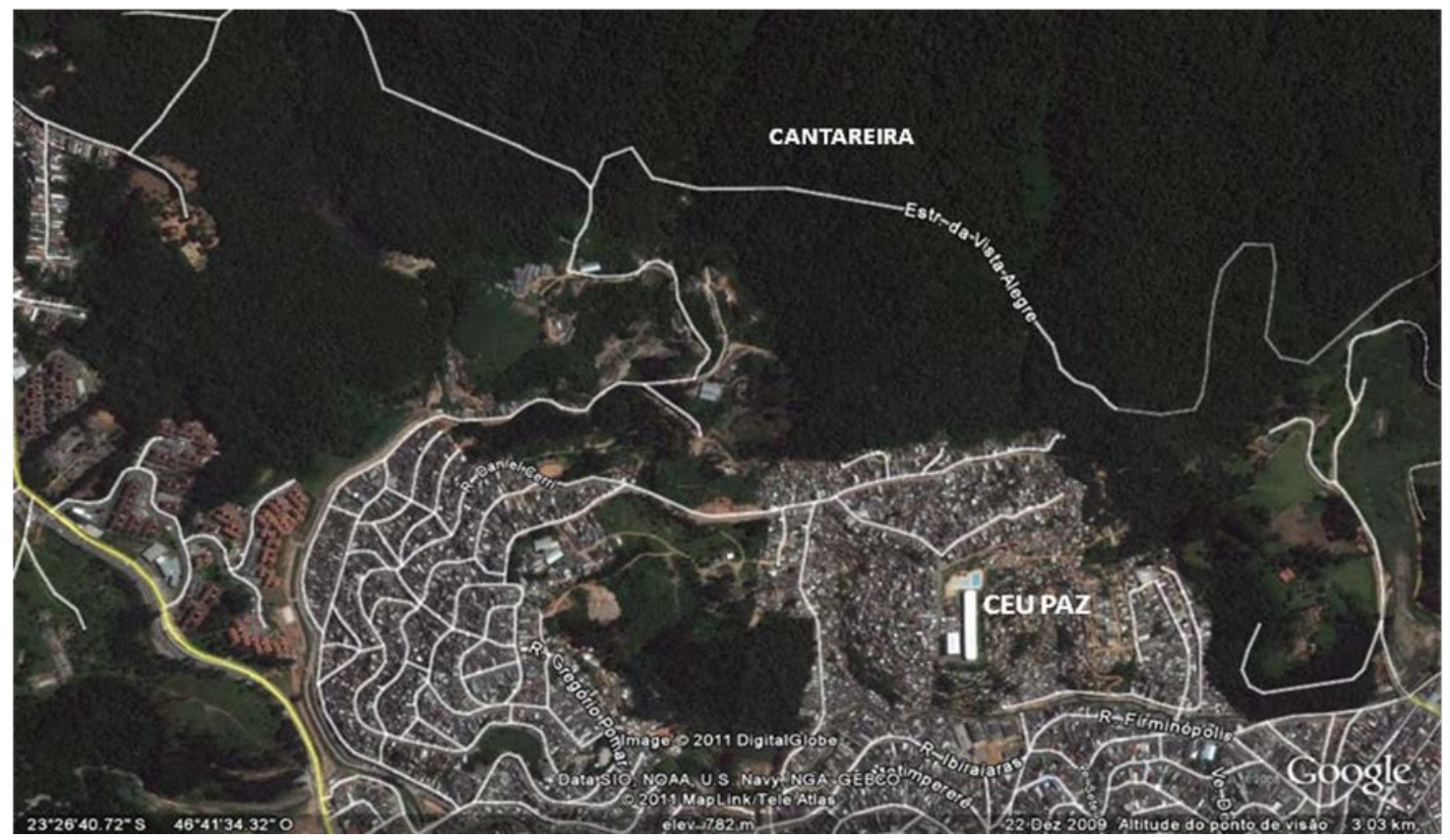

Foto 11 - Foto aérea do CEU - Paz

Fonte: Google Earth - imagens 2009

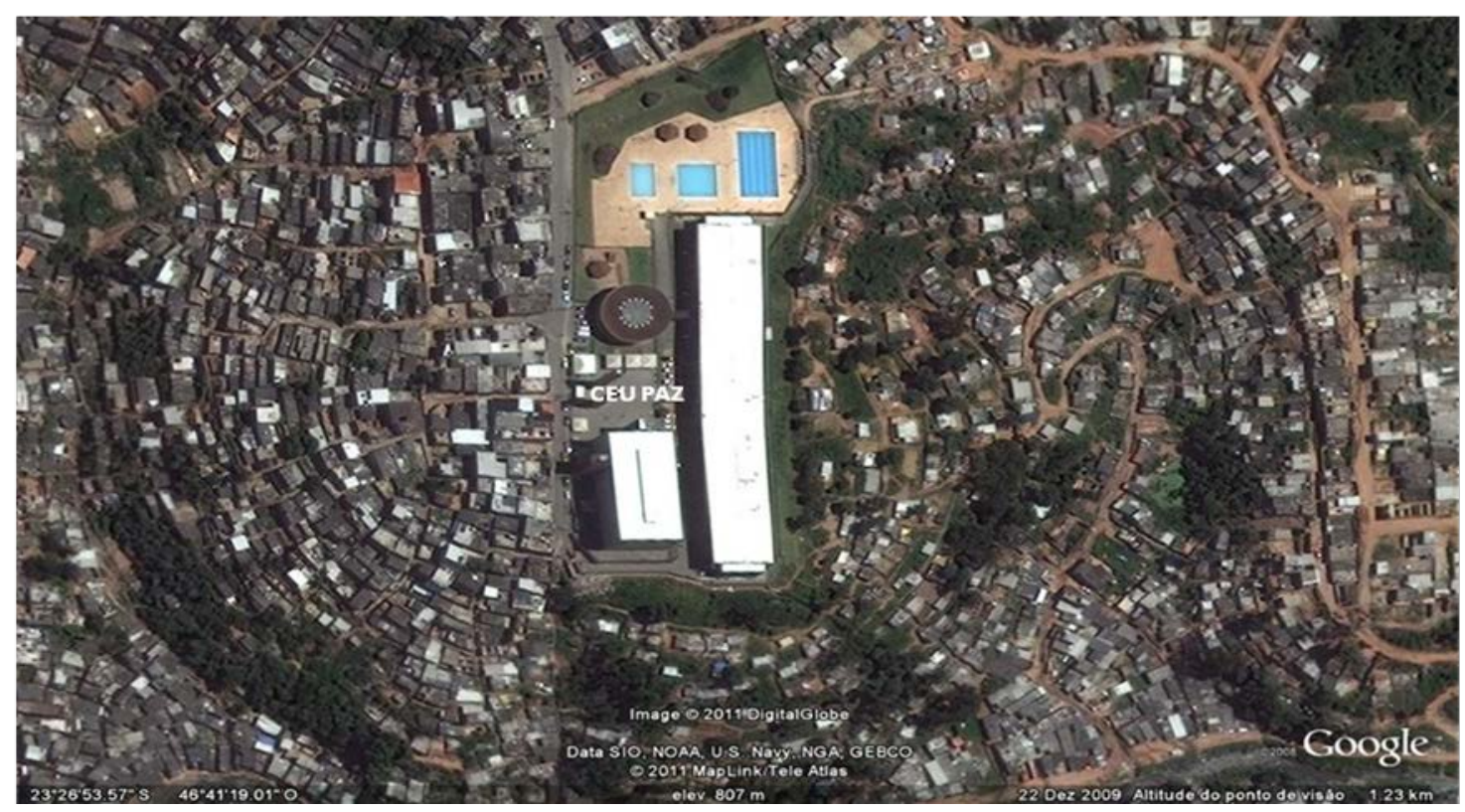

Foto 12 - Foto aérea do CEU - Paz

Fonte: Google Earth - imagens 2009

O CEU Três Pontes, erguido sobre a várzea do rio Tietê no Jardim Romano, zona leste de São Paulo, ficou totalmente alagado no verão de 2010, juntamente com um conjunto habitacional construído na região pelo poder público. Na realidade todo o bairro foi irregularmente implantado sobre a Área de Preservação Permanente do Tietê e a cada período de chuvas mais intensas sofre com as enchentes (Foto 13). Com a construção de um dique executado junto à margem do 
rio, os alagamentos na região do CEU e do conjunto habitacional, assim como no seu entorno imediato foram momentaneamente controlados.

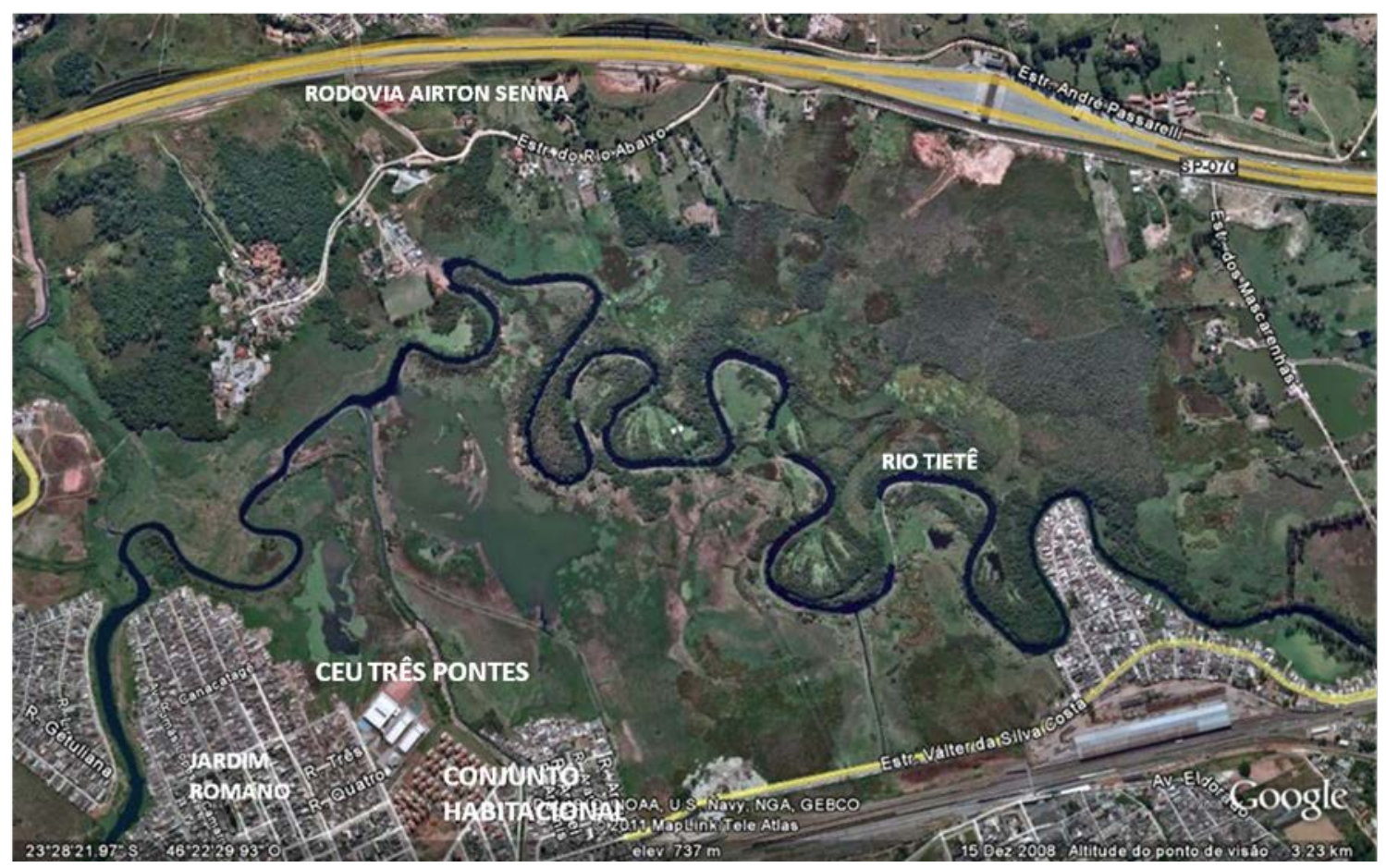

Foto 13 - Foto aérea do CEU - Três Pontes e da várzea do rio Tietê

Fonte: Google Earth - imagens 2009

Entre as recentes intervenções envolvendo a rede hídrica estrutural da cidade está a construção de faixas de rolamento adicionais nas vias marginais do rio Tietê, com a remoção de inúmeras árvores e a pavimentação de grandes áreas, que contribuiu para o aumento da superfície impermeabilizada na cidade, sinalizando para uma política de incentivo ao transporte individual, em prejuízo das modalidades de transporte coletivo. Neste caso, em particular, houve diversos questionamentos com relação à efetiva execução das medidas estabelecidas pelo licenciamento ambiental, particularmente quanto às compensações dos danos ambientais causados pela obra, e em especial no que se refere ao plantio de árvores nas regiões adjacentes ao empreendimento.

Já o Plano Diretor Estratégico do Município de São Paulo, aprovado pela Lei $n^{\circ}$ 13.430, de 13 de setembro de 2002, prevê a implantação de parques lineares como uma das ações estratégicas para a gestão da Política Ambiental. Os parques lineares, assim como os caminhos verdes, constituem intervenções urbanísticas do Programa de Recuperação Ambiental de Cursos D’Água e Fundos de Vale, instituído pelo Plano Diretor Estratégico. O programa está vinculado à rede hídrica 
estrutural e compreende uma série de ações coordenadas pelo Executivo, com a finalidade de "promover transformações urbanísticas estruturais e a progressiva valorização e melhoria da qualidade ambiental da Cidade", mediante a participação de proprietários, moradores, usuários e investidores. Nestas condições, os parques lineares configuram-se como projetos que deveriam ser tratados de forma interdisciplinar e interinstitucional, por apresentarem características diversas dos parques urbanos tradicionais, uma vez que estão necessariamente associados à existência de cursos d'água e fundos de vale e não constituem obrigatoriamente áreas cercadas, o que torna imprescindível a colaboração entre diferentes setores do poder público e o envolvimento da população do entorno na sua concepção, implantação e manutenção.

A efetiva discussão sobre os parques lineares pelo corpo técnico da municipalidade, do qual o autor do presente trabalho fez parte, teve início em meados de 2006. Naquela ocasião foram levantadas questões como a necessidade de se considerar a existência de diferentes tipologias de parques lineares, em função do grau de preservação das condições naturais e de urbanização da área, e de haver um tratamento diferenciado para cada situação. Da mesma forma, foram colocados como aspectos fundamentais a necessidade de se levar em conta a disponibilidade de áreas públicas, a dificuldade para a desapropriação de áreas privadas e a existência de favelas ou construções irregulares, assim como a realização de um trabalho de forma integrada com os demais órgãos da administração e com a população local.

Durante os anos que se seguiram, o que se verificou na prática foram as imensas dificuldades para a viabilização desses parques, justamente em razão da desatenção aos aspectos citados anteriormente, tendo em vista a urgência política da implantação de tais projetos.

A incompatibilidade entre o imediatismo dos tempos políticos e os tempos necessários ao desenvolvimento de trabalhos integrados e consistentes tende, neste caso, à criação de espaços urbanos não apropriados pela população e propensos ao abandono, à degradação e à insegurança.

O caso do parque Nove de Julho, executado pela municipalidade na orla da represa de Guarapiranga, situada na área de proteção aos mananciais da cidade, 
revela novamente o aparente contrassenso dos projetos executados pelo poder público.

Em setembro de 2009, o Ministério Público de São Paulo obteve uma liminar que suspendia a construção do parque, cujo projeto previa a instalação de quadras esportivas e de passeios para pedestres, tendo três quartos de sua superfície sobre a área inundável da represa. Naquela data já havia uma pista de concreto com 1,6 km de extensão construída no local (Foto 14) e, apesar dos danos ambientais já causados pela obra, o Tribunal de Justiça de São Paulo decidiu por unanimidade pela cassação da liminar, em outubro de 2010, aceitando o argumento apresentado pela prefeitura de que "a criação do parque tem como objetivo promover o uso público sustentável de área verde, diminuir a ocupação desordenada da área e melhorar a qualidade do meio ambiente", conforme notícia divulgada pelo jornal "Folha de São Paulo", em 03/11/2010. Cabe aqui não só questionar o sentido da sustentabilidade alegada na defesa da continuidade das obras, mas também a própria concepção de um projeto que propõe a utilização de estruturas de concreto assentadas diretamente sobre terrenos naturalmente alagáveis.

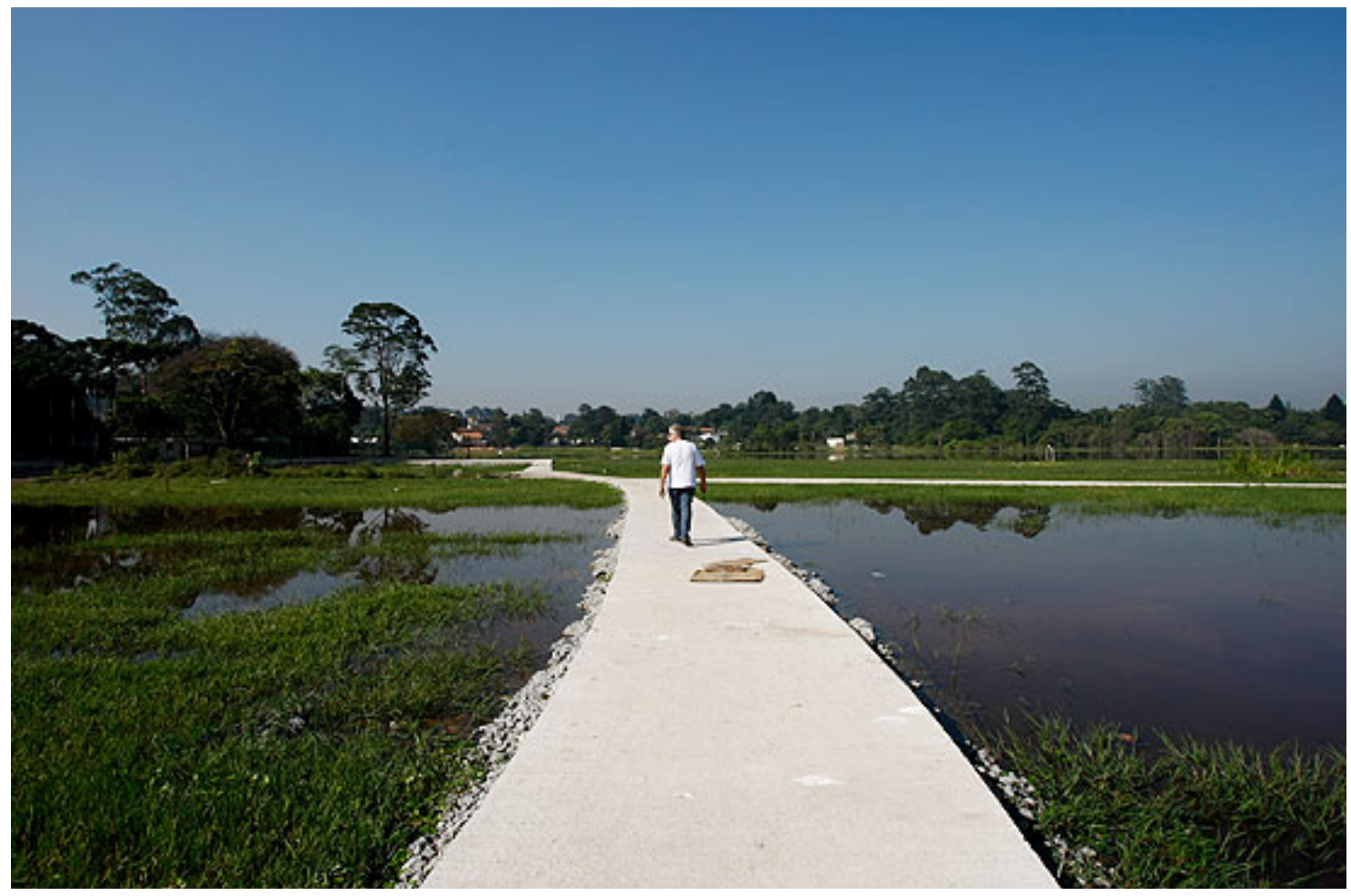

Foto 14 - Foto da passarela de concreto construída sobre área alagadiça da represa Guarapiranga, no parque 9 de Julho

Fonte: Folha de São Paulo. Justiça libera construção de parque na Represa Guarapiranga. 10/09/2010. Disponível em: <http://www1.folha.uol.com.br/cotidiano/825013-justica-libera-construcao-de-parque-narepresa-de-guarapiranga-em-sp.shtml>. Acesso em: 10 set. 2010. 
No campo dos instrumentos de caráter compensatório, o Plano Diretor Estratégico do Município de São Paulo (Lei no 13.430, de 13 de setembro de 2002) prevê o Termo de Compromisso Ambiental (TCA), definido como o instrumento de gestão ambiental "celebrado entre o Poder Público Municipal e pessoas físicas ou jurídicas, resultante da negociação de contrapartidas nos casos de autorização prévia para supressão de espécies arbóreas", devendo a compensação "ser prioritariamente estabelecida em exemplares arbóreos, de acordo com os projetos da Secretaria Municipal do Verde e do Meio Ambiente". Em outras palavras, o TCA autoriza o corte de espécies arbóreas quando se pretende executar uma obra pública ou privada, tendo como contrapartida o fornecimento de mudas em quantidades a serem definidas pela Municipalidade. A lei admite, excepcionalmente, a conversão da compensação em obras e serviços, "mediante decisão fundamentada do Secretário Municipal do Verde e do Meio Ambiente", desde que eles estejam "relacionados com a eliminação ou redução de dano ambiental". Apesar do caráter de exceção desta disposição, ela tem sido a prática habitual no Município de São Paulo, ao se converter o fornecimento de mudas em levantamentos planialtimétricos e projetos de áreas verdes, ou ainda na execução das obras para a implantação destes projetos, além de reformas em parques existentes.

A realidade, no entanto, mostra que muitos dos projetos elaborados no âmbito do poder público jamais chegam a ser executados, ainda mais num quadro de descontinuidade administrativa. A consequência mais grave deste fato é que, na medida em que a supressão das espécies arbóreas é previamente autorizada, a pressuposta compensação acaba não se concretizando, apesar do dano ambiental já ter ocorrido, e mesmo nas situações em que a conversão ocorre na forma de obras civis, a compensação, do ponto de vista ambiental, também não se efetiva. Assim, ainda que o TCA seja empregado como subterfúgio para superar a eventual falta de recursos financeiros, faz-se necessário lembrar que o objetivo fundamental deste instrumento, conforme explicitado na própria lei, consiste na eliminação ou redução do dano ambiental.

Além do mais, entende-se que a utilização do TCA deveria se restringir à supressão de um pequeno número de espécies arbóreas, evitando-se dessa maneira a eliminação de massas significativas de vegetação numa mesma área. 
Assim, ao permitir o corte "legal" de exemplares arbóreos de forma indiscriminada, o TCA se transforma num instrumento bastante conveniente, tanto para o setor imobiliário como para o setor público.

De maneira semelhante, as medidas mitigatórias previstas nos instrumentos de avaliação ambiental, como Estudos de Impacto Ambiental e Estudos de Impacto de Vizinhança, acabam atendendo aos mesmos intentos das compensações ambientais dos TCAs. O recente exemplo da obra de ampliação das faixas das vias marginais do Rio Tietê, viabilizada por meio da eliminação dos canteiros centrais vegetados existentes, demonstra o uso equivocado desses instrumentos. Aqui, o viário foi novamente priorizado, beneficiando o transporte de cargas e o transporte individual, com o intuito de desafogar o pesado trânsito daquelas vias, na contramão de políticas de incentivo ao transporte coletivo, numa situação em que um meio de alta capacidade como o metrô já dá claros sinais de saturação e o serviço de transporte por ônibus se mostra cada vez mais ineficiente.

O poder público tem se caracterizado, de maneira geral, por formas de atuação cada vez mais imediatistas e distantes de uma perspectiva de longo prazo, muitas vezes atuando somente de modo emergencial nas situações de desastres naturais, como nas enchentes e nos deslizamentos de terra que têm atingido diversas regiões do país nos períodos de chuvas intensas dos últimos anos.

A descontinuidade administrativa encontra um forte aliado no aumento exacerbado das funções comissionadas em todos os níveis hierárquicos, fato que favorece o seu uso político, as práticas de nepotismo e, principalmente, a dificuldade na formação de quadros estáveis de servidores que efetivamente garantem a continuidade do serviço público, independentemente de quem esteja no poder e dos conflitos de interesses que possam surgir. A persistência deste modelo compromete não só a qualidade do serviço prestado, mas também a defesa da autonomia do trabalho técnico, garantida pela condição da estabilidade funcional.

Estudos realizados pela OCDE (Organização para Cooperação e Desenvolvimento Econômico), divulgados pelo jornal "Folha de São Paulo", em 16/01/2011, indicam que o modelo de Direção e Assessoramento Superiores (DAS), adotado pelo Brasil para o provimento de cargos públicos, sem a necessidade de concurso público, além de abranger um número exagerado de postos, "não oferece transparência nos critérios de nomeação nem avalia o desempenho dos nomeados". 
Estes cargos visam, basicamente, "o preenchimento de postos políticos, recrutamento de profissionais do setor privado e ascensão profissional de servidores públicos de carreira". No nível federal, segundo a reportagem, eles representavam, na época, 22 mil postos de um total de 570 mil funcionários no Poder Executivo, enquanto que nos Estados Unidos o número de cargos de livre provimento seria em torno de 7 mil, constantes de uma lista elaborada pelo Congresso, logo após a eleição presidencial, além de 8 mil postos para o alto escalão, dos quais metade destinada a servidores que passam por um processo de seleção. Para citar outros países, na Holanda são 780 cargos, e no Chile 837 vagas. Na avaliação do estudo, "é difícil para o público brasileiro saber onde termina a atividade política e onde começa a administração profissional", acrescentando ainda que "não há descrições publicamente disponíveis das competências requeridas para as posições ou dos méritos das pessoas selecionadas".

$\mathrm{Na}$ mesma direção encontra-se a crescente terceirização dos serviços públicos, sob o repetido argumento da economia de recursos e do aumento da eficiência no atendimento à população, novamente em detrimento da formação de um corpo técnico profissional e estável, capaz de dar a mínima continuidade ao andamento dos trabalhos e de preservar a memória de todo o trabalho desenvolvido ao longo de anos.

Além disso, observa-se a repetição de uma prática predominante por parte de governantes de demonstrar o desempenho da administração com base em aspectos puramente quantitativos, muito frequentes nos discursos de representantes do Poder Executivo, para enfatizar, por exemplo, o número de apartamentos construídos para abrigar famílias removidas de áreas de risco, o número de pessoas atendidas por determinado serviço, ou a quantidade de metros quadrados de áreas verdes implantadas na cidade, sem que se considere a qualidade e a forma como tais ações são concebidas, planejadas e executadas.

Esse contexto pode, em grande parte, ser creditado ao movimento de reforma do Estado, observado em nível mundial especialmente a partir dos anos 80, no esteio das mudanças no cenário econômico global e do avanço do pensamento neoliberal.

Drucker (1993), por exemplo, defendia um modelo no qual somente o exercício de um número muito restrito de funções, consideradas exclusivas de 
governo, permaneceria a cargo do Estado. No campo social, entendia que as tarefas deveriam ser terceirizadas ao setor privado e às entidades do "terceiro setor", sob o argumento de que o governo havia fracassado nos papéis de executor e gerente nesta área, devendo, portanto, deixar de exercê-los e limitar-se à definição da política. Além disso, em sua avaliação, existia a necessidade de elevar o nível de produtividade do trabalho em serviços, visto que os funcionários da área pública seriam os menos produtivos.

Bizelli (2009, p.22) destaca a ocorrência de um processo de flexibilização da produção e das relações de trabalho como consequência da mudança estrutural no modelo de acumulação, quando se observa um movimento de desvalorização do setor industrial em relação ao terciário e um processo de desformalização e informalização dos mercados de trabalho, resultante do impacto da terciarização, "agravado pela tendência à informatização e pelo movimento de migração de mãode-obra". A partir desse quadro, amplia-se o número daqueles que passam a defender a ideia de que os governos deveriam ser reinventados de acordo com princípios gerenciais que garantissem "agilidade para fazer face à vulnerabilidade das economias dependentes do volátil dinheiro internacional", valorizando aspectos como eficácia, eficiência e redução de custos e estimulando sistemas de avaliação de desempenho da máquina administrativa pública.

As dificuldades para se trabalhar de forma interdisciplinar e interinstitucional não são uma exclusividade do serviço público, porém é provável que neste setor os entraves de caráter burocrático, político e de poder se manifestem de forma mais contundente, tornando mais árdua a realização de experiências que fogem dos padrões habituais, mas que tanto do ponto de vista técnico como da interação com a população são absolutamente enriquecedoras, tendo como resultado a implantação de projetos mais sólidos e duradouros.

Neste sentido, o projeto do parque linear do córrego Água Podre pode ser apontado como uma tentativa de atuação interdisciplinar e interinstitucional, ainda que momentânea, ao reunir técnicos de vários setores da Municipalidade e envolver a participação da população local, a partir de um trabalho originado da iniciativa de servidores do então Núcleo de Gestão Descentralizada Oeste, localizado no Parque Previdência e vinculado à Secretaria do Verde e do Meio Ambiente. 
O córrego Água Podre está situado no Distrito do Rio Pequeno, na Subprefeitura do Butantã, Município de São Paulo, e faz parte da bacia do Ribeirão do Jaguaré, com uma extensão aproximada de dois quilômetros. A versão conhecida para a denominação do córrego diz respeito ao fato de que a região da nascente, antes da ocupação do bairro, era formada por um grande brejo que dava um aspecto turvo à água. Um pequeno remanescente dessa formação ainda pode ser encontrado numa das entradas do CEU Butantã, o que só reforça a importância da manutenção da denominação de "Água Podre" ao parque linear como forma de resgate da memória local.

A criação do Parque Linear Água Podre percorreu uma trajetória distinta dos demais, tendo início em julho de 2006 com a indicação, por técnicos da Subprefeitura do Butantã, da Secretaria do Verde e Meio Ambiente e da então Empresa Municipal de Urbanização (EMURB), da área do córrego Água Podre, para a aplicação dos recursos provenientes das obrigações ambientais assumidas pela EMURB, em decorrência das obras de construção de uma ponte estaiada sobre o Rio Pinheiros, por meio do firmamento de um Termo de Compromisso Ambiental.

O projeto do parque, inicialmente restrito a um trecho denominado Esmeralda, por estar localizado no Jardim Esmeralda, e posteriormente estendido para toda a extensão do córrego, teve suas atividades efetivamente iniciadas com a constituição de um grupo de trabalho, formado por técnicos, do qual tivemos a oportunidade de participar até meados de 2008, e coordenado pela Subprefeitura local. O grupo tomou como premissas básicas que a área do projeto deveria abranger toda a subbacia hidrográfica e que a sua implantação deveria ser realizada mediante um processo participativo, no qual a população tivesse um envolvimento efetivo em todo o processo.

Em virtude de suas características, é possível identificar sete trechos com características distintas da nascente, junto à Rodovia Raposo Tavares (Foto 15), até o seu encontro com o Ribeirão do Jaguaré, ao longo dos quais se encontram um CEU (Foto 16), logo após a nascente, duas favelas (Fotos 17 e 18), uma adutora, uma linha de alta tensão (Foto 19), alternados por espaços mais urbanizados e menos ocupados, como o trecho Esmeralda, uma área pública bastante arborizada (Fotos 20 e 21). 
O CEU apresenta-se como num capítulo à parte no parque linear, por constituir uma interrupção do percurso do córrego, imediatamente após a sua nascente, tendo em vista que foi implantado exatamente sobre o seu leito, evidenciando uma prática comum entre profissionais do projeto de ignorar a presença dos cursos d'água no meio urbano, ao invés de tirar partido deles, fato que se repete em outras unidades dos CEUs na cidade.

As atividades técnicas previstas na construção do parque linear incluíram uma etapa inicial de diagnóstico, que procurou identificar potencialidades e fragilidades na área do projeto, do qual fizeram parte o estudo hidrológico, o levantamento planialtimétrico, o levantamento das áreas livres e de seus usos atuais e o cadastramento da arborização, entre outras. Ações de recuperação ambiental da bacia, com a elaboração de projetos de drenagem e de despoluição do córrego e sua posterior implementação, constituíram etapas seguintes de trabalho, assim como a elaboração e a implantação do projeto paisagístico.

Como procedimento, visando à participação da comunidade no processo, reuniões com toda a população moradora da região foram realizadas periodicamente. Mesmo diante da proposta do grupo técnico de realizar encontros setorizados menores, a comunidade entendia que a melhor maneira de conduzir as discussões a respeito do parque linear era por meio de reuniões maiores.

O redirecionamento do projeto, como resultado de questionamentos realizados pela população, levou à articulação do grupo de trabalho com a SABESP, empresa estadual responsável pelo abastecimento de água e tratamento do esgoto, no sentido de incluir do Água Podre no programa "Córrego Limpo", que tem como objetivo a despoluição de córregos na cidade com a interrupção do lançamento de efluentes sem tratamento diretamente nos corpos d'água, por meio da instalação de coletores que recolhem os esgotos provenientes das ocupações existentes na bacia. Os entendimentos com a empresa culminaram com a inclusão do córrego no programa, atendendo aos anseios da comunidade, que reiterava o entendimento de que o parque linear só teria sentido com a melhoria da qualidade das suas águas. Outro aspecto levantado durante as reuniões foi a necessidade de colocar em prática ações de educação para discutir o processo de degradação do curso d'água e as medidas visando à sua recuperação. 
O que deve se destacar como diferencial deste projeto, em relação aos demais parques lineares, é a forma como vinha sendo conduzido junto à população e entre os diferentes órgãos da Administração Pública. A reunião de diversas Secretarias Municipais, da EMURB e da SABESP num grupo de trabalho, sob a coordenação da Subprefeitura local, para a concepção e implantação de um parque linear é uma experiência única entre os parques implantados no mesmo período na cidade, que se torna mais significativa, quando se considera que ações como a despoluição do córrego, a construção de unidades habitacionais para a população removida, em área na própria bacia, a realização de atividades de educação ambiental com os moradores e as escolas locais, vinham sendo desenvolvidas de forma conjunta. É natural a ocorrência de conflitos num processo que envolve a participação da população e de órgãos públicos e questões legais, técnicas, burocráticas, orçamentárias e políticas, que implicam negociações para se chegar a um entendimento, como no caso das soluções adotadas para o tratamento do canal, discutidas com a Secretaria de Infraestrutura Urbana - SIURB, e da implantação de unidades habitacionais pela Superintendência de Habitação Popular - HABI.

Fato comum nas obras públicas, mesmo com o empenho dos técnicos e do interesse e da cobrança da população local, o projeto passou por períodos de indefinições, em razão de mudanças políticas e consequentes alterações na equipe de trabalho e empecilhos de ordem técnica e administrativa, entre outros problemas, sendo retomado recentemente, com o início das obras, ainda assim com certa dificuldade.

Como ação relacionada ao Parque Linear do Água Podre e com o objetivo de disseminar a ação estratégica, constante do Plano Diretor Estratégico do Município, de promover a recuperação urbana e ambiental de córregos e fundos de vale por meio dos parques lineares, a equipe técnica do Núcleo de Gestão Descentralizada Centro-Oeste elaborou o projeto "A Educação Ambiental na Implantação de Parques Lineares", com recursos do Fundo Municipal de Meio Ambiente - FEMA, dirigido à comunidade escolar, em parceria com seis escolas da Subprefeitura do Butantã, próximas aos córregos que receberão parques lineares. O projeto foi desenvolvido em módulos para professores e alunos, tendo como metodologia orientadora da ação pedagógica o estudo do meio e como objeto de estudo os córregos da região, com a finalidade de realizar o diagnóstico da realidade socioambiental local e 
difundir o processo de construção dos parques lineares como nova forma de abordagem no tratamento de bacias hidrográficas da cidade, assim como de estratégia para promover a recuperação dos córregos como espaço de conservação e convivência.

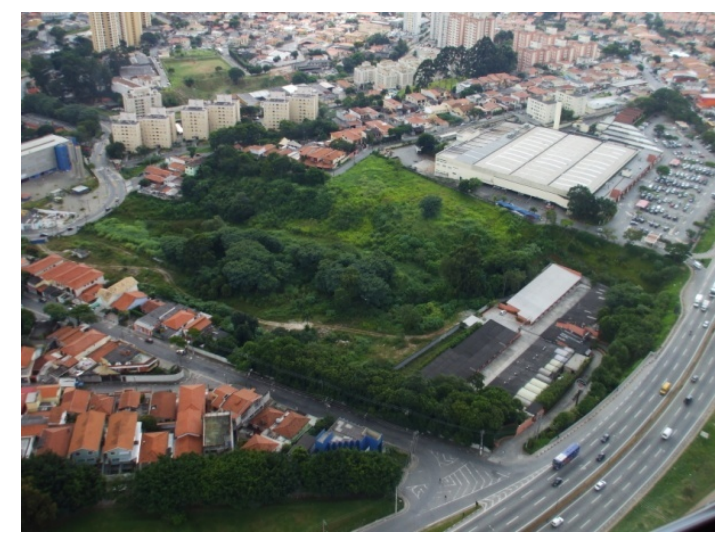

Foto 15 - Área da nascente, junto à Rodovia Raposo Tavares

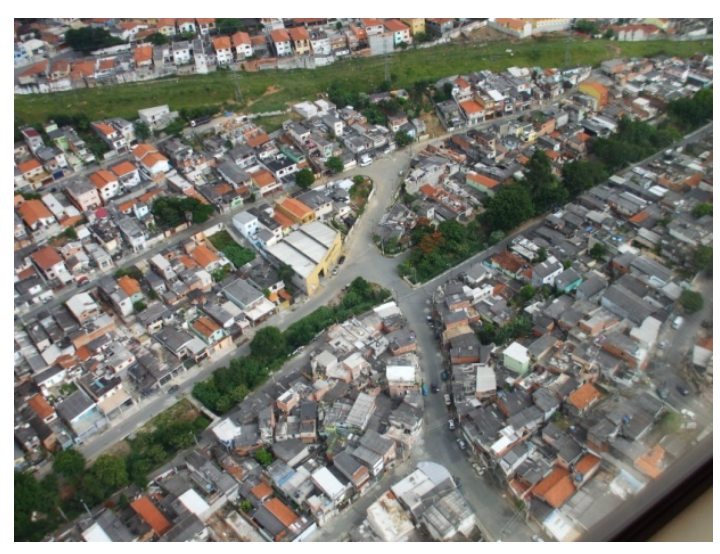

Foto 17 - Vista aérea, com córrego Água Podre, ao centro, e favela Imperatriz Dona Amélia abaixo

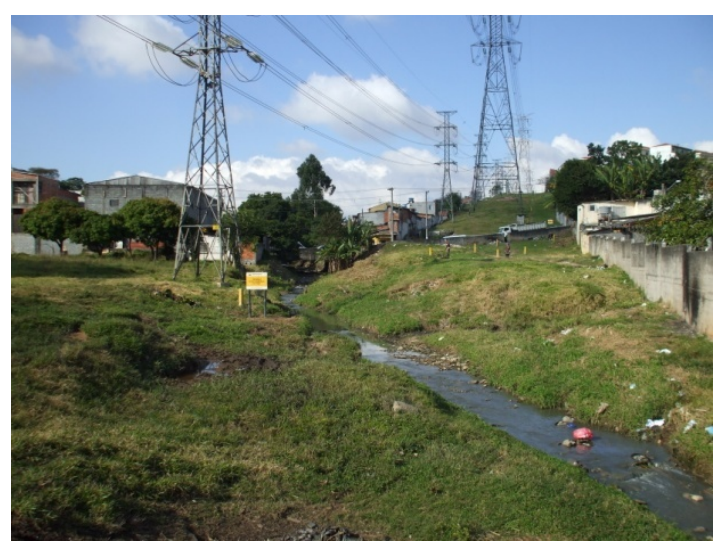

Foto 19 - Córrego Água Podre, no trecho da linha de transmissão

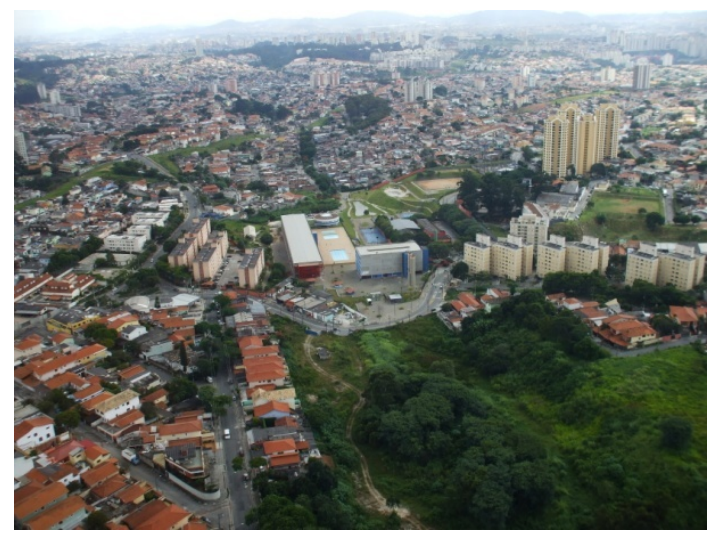

Foto 16 - Vista do CEU - Butantã, ao centro

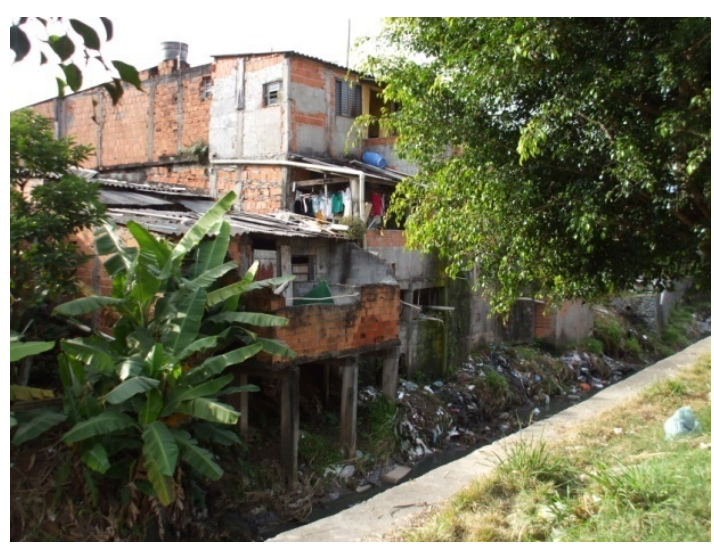

Foto 18 - Favela Maria Lúcia, junto à Avenida Rio Pequeno, com habitações a serem removidas

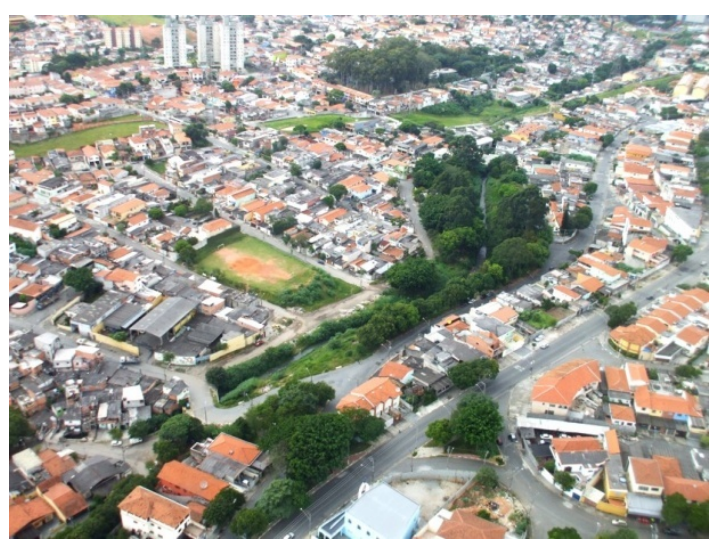

Foto 20 - Vista aérea, com Trecho Esmeralda, ao centro 


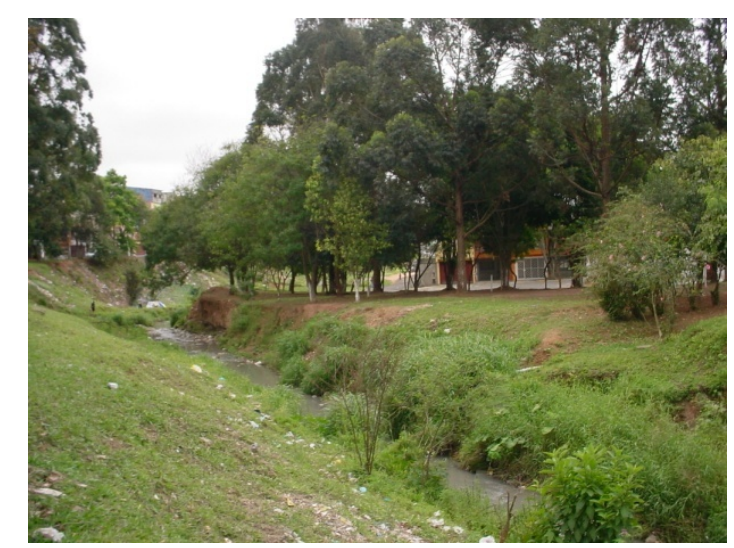

Foto 21 - Área pública no Trecho Esmeralda: vista de montante para jusante

Fonte: Divisão Técnica do Núcleo de Gestão Descentralizada Centro-Oeste da Secretaria do Verde e Meio Ambiente

\subsection{O Gerenciamento de Áreas Contaminadas pelo poder público}

A problemática ambiental passou a fazer parte do cotidiano da população em geral a partir de um passado muito recente, e as políticas públicas voltadas a este aspecto têm dado maior ênfase ao combate de determinadas formas de poluição, em especial aquelas mais perceptíveis pelos sentidos e as que produzem efeitos mais imediatos à saúde humana.

A poluição do solo, ao contrário, ainda é vista como um problema menor certamente porque é pouco visível e as suas consequências manifestam-se de forma quase sempre silenciosa. Alguns poluentes podem permanecer retidos por anos no solo, ou mesmo migrar para as águas subterrâneas, ameaçando importantes depósitos de um líquido essencial para a sobrevivência humana, e é por este motivo que as antigas áreas industriais adquirem uma importância fundamental no processo de reocupação dos espaços urbanos.

O caso mais conhecido de contaminação do solo, o de Love Canal, em Niagara Falls, Estados Unidos, teve origem com o depósito de resíduos industriais, entre 1942 e 1953, num canal cujas obras haviam sido abandonadas, e apenas em meados da década de 1970 as inúmeras ocorrências de doenças foram associadas à existência da contaminação. No Brasil, somente na década de 1980, com a divulgação da presença de contaminação em áreas como a da Rhodia, em Cubatão, e das Indústrias Matarazzo, em São Caetano do Sul, é que a poluição do solo passou a ser uma área de efetiva atuação do órgão ambiental estadual em São Paulo. 
É possível afirmar que os países industrializados que mais têm avançado no gerenciamento de áreas contaminadas desenvolvem ações sistematizadas com o objetivo de identificar, diagnosticar e promover a recuperação destes terrenos e, em alguns casos, já se adiantam no sentido atuar de um forma preventiva, mediante o controle sobre atividades com potencial de contaminação e empreendimentos em processo de desativação.

Ainda que se identifiquem algumas iniciativas que apontem na direção de uma atitude mais corretiva e até mesmo preventiva, especialmente no que diz respeito à legislação específica vigente no estado e no município de São Paulo, a atuação do poder público frente ao problema, no Brasil, é pautada por casos que ainda revelam uma postura reativa.

O caso da área conhecida como Boi Malhado, na Vila Nova Cachoeirinha, zona norte da cidade de São Paulo, pode ser enquadrada nesta condição, visto tratar-se de um terreno que recebeu resíduos orgânicos, industriais, entulhos e lixo hospitalar por cerca de vinte anos, entre os anos de 1960 e 1980, sobre o qual foram implantadas unidades habitacionais em sistema de mutirão pela COHAB nos anos 1990 e duas escolas municipais, além de um campo de futebol. A contaminação no local foi identificada pela CETESB, que constatou uma alta concentração de gás metano com risco de explosão.

A agravante aqui se constitui no fato de que a implantação das unidades habitacionais e das escolas foi realizada com o aval do próprio poder público municipal. As obras realizadas pela COHAB só foram paralisadas em 2001, ocasião na qual a CETESB fez uma série de exigências, entre elas a instalação de um sistema de extração de gases, além da execução de uma investigação detalhada e da remoção dos moradores, sendo que em 2007 uma decisão judicial ordenou a retirada de todas as famílias pela $\mathrm{COHAB}$, e um acordo firmado entre a CETESB e a Prefeitura estabeleceu a transferência das escolas municipais. Apesar disso, as edificações que abrigavam as escolas permaneceram no local e acabaram sendo invadidas por membros do movimento por moradias, abrigando em janeiro de 2013 mais de 400 famílias, mesmo sob o risco da ocorrência de explosões.

Este episódio remete à tragédia do Morro do Bumba, em Niterói, estado do Rio de Janeiro, ocorrida em abril de 2010. Apesar de ser um exemplo externo à cidade de São Paulo, pode ser considerado um caso emblemático para demonstrar 
o descaso com que o Estado tem tratado a questão habitacional e as ocupações irregulares, invariavelmente em áreas ambientalmente frágeis, que aliadas aos problemas sociais, produzem situações absolutamente nefastas. No Morro do Bumba, após um período de chuvas intensas na região, uma favela erguida com a conivência do poder público sobre um lixão desativado acabou deslizando e vitimando inúmeros moradores, apesar de estudos sobre a área já terem alertado para o risco de desabamento (Fotos 22). Após a remoção das famílias, o local vem sofrendo obras de reconstrução e de revegetação, o que só vem a reforçar a ideia de que o poder público, de maneira geral, só age após a ocorrência da tragédia ou do dano (Foto 23).

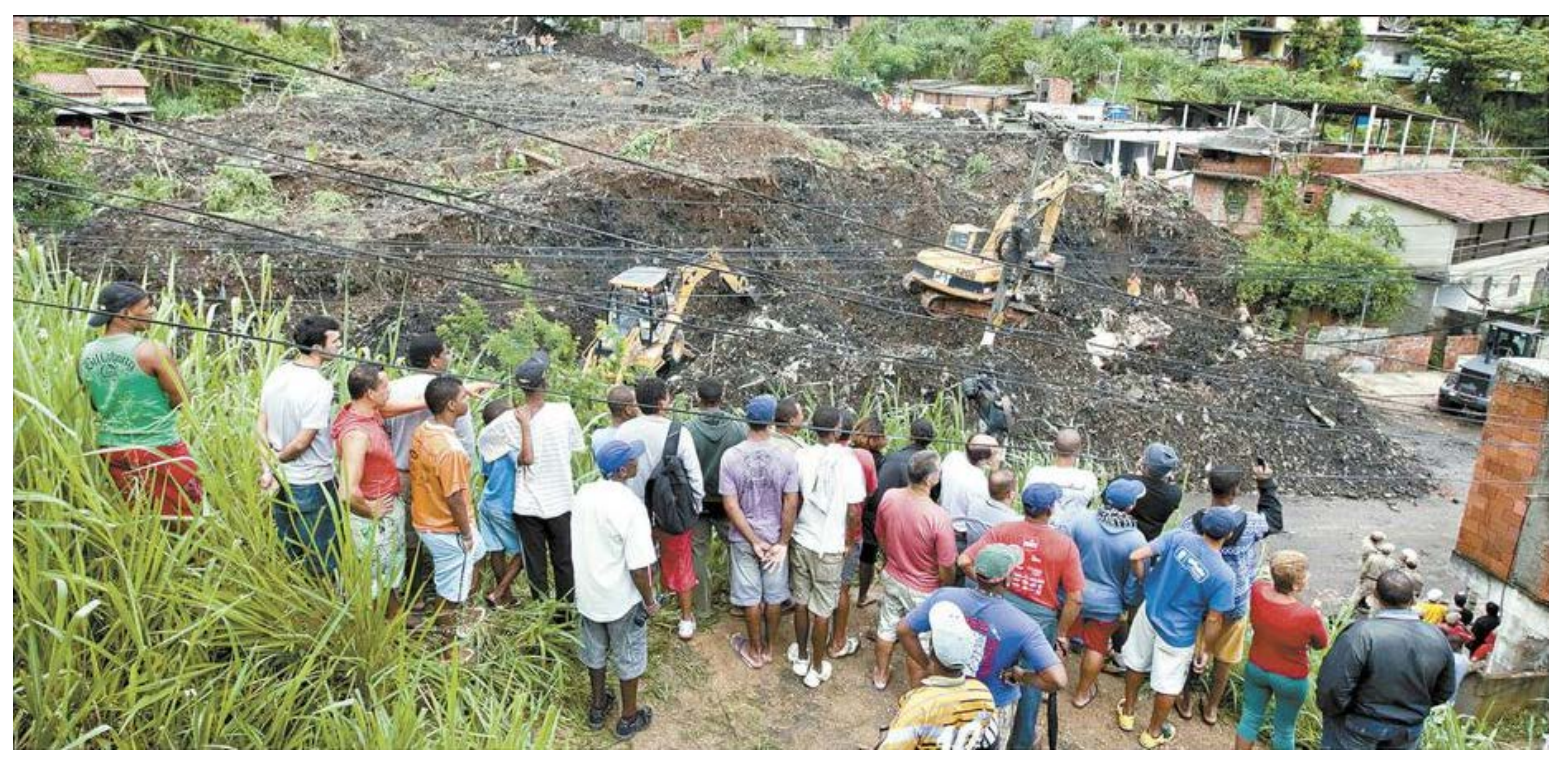

Foto 22 - Deslizamento do Morro do Bumba, Niterói - RJ, em abril de 2010

Fonte: Fonte: Folha de São Paulo. 'Há estudos a respeito de tudo', diz prefeito. 09/04/2010. Disponível em: < http://acervo.folha.com.br/fsp/2010/04/09/15>. Acesso em: 19 abr. 2011. 


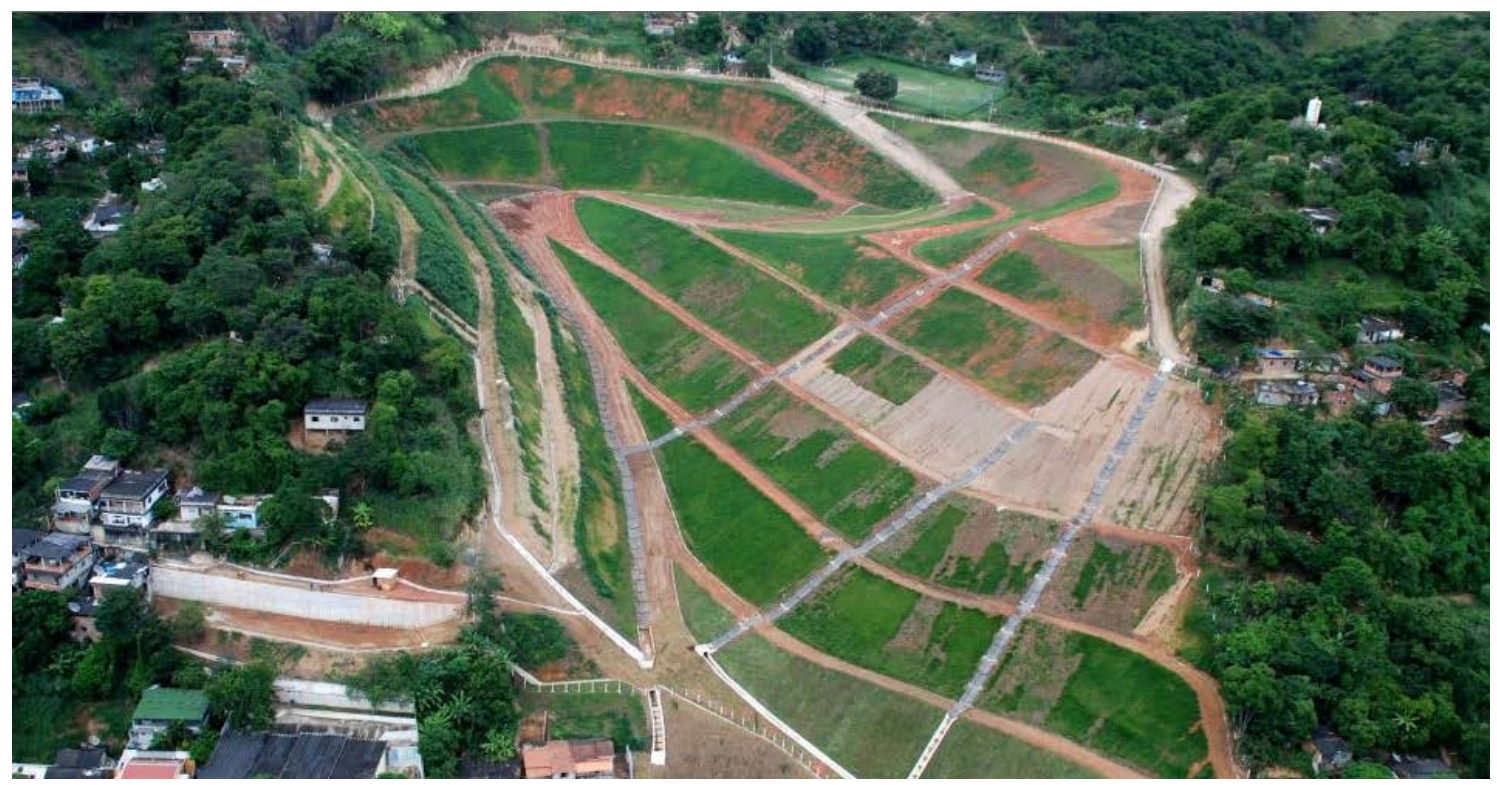

Foto 23 - Obras de reconstrução do Morro do Bumba, Niterói - RJ, após deslizamento

Fonte: Portal UOL. Tragédia no Morro do Bumba completa um ano. 24-03-11. Disponível em: $<$ http://noticias.uol.com.br/album/110405bumba_album.jhtm> Acesso em: 24 abr. 2011

Outra situação de ocupação de antigos depósitos de resíduos encontra-se na região de Brasilândia, extremo norte da cidade de São Paulo. O aterro do Jardim Damasceno foi um dos locais utilizados na década de 1970 pela Prefeitura do Município de São Paulo para a deposição de resíduos sólidos, numa época em que não havia aterros sanitários na cidade e o gerenciamento desta questão ainda era muito incipiente. O controle precário dessas áreas pela Administração Municipal e a falta de opções de moradia pela população de baixa renda favoreceram a invasão do aterro, após o seu encerramento, dando origem a mais uma das inúmeras áreas de risco da cidade (Foto 26).

A menos de quinhentos metros do aterro do Jardim Damasceno, às margens do córrego do Bananal, um loteamento irregular também se encontra implantado sobre outro antigo depósito de resíduos, onde há alguns anos a CETESB constatou a liberação de gases na rede pública de águas pluviais (Foto 24). 


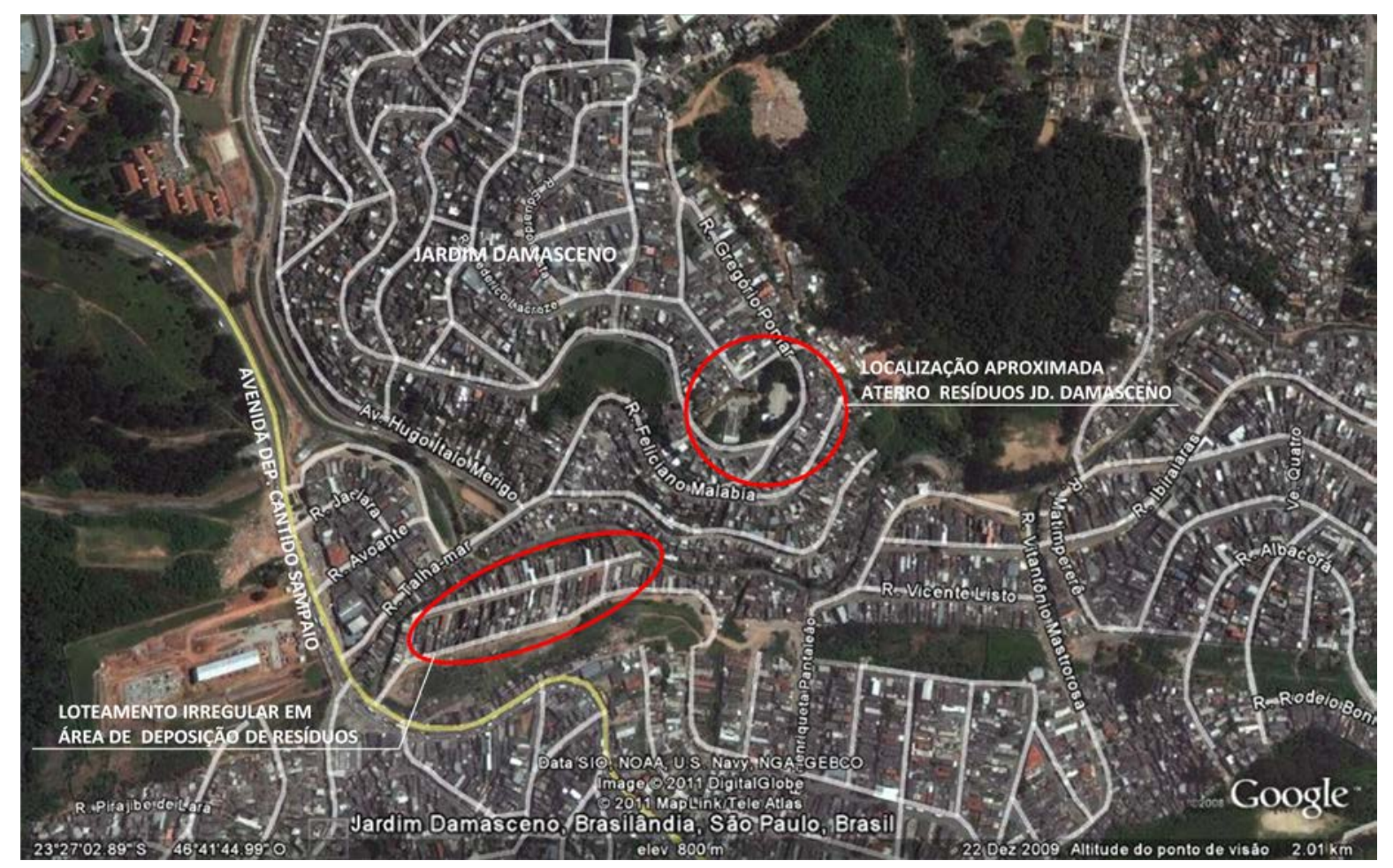

Foto 24 - Foto aérea da região de Brasilândia, com a localização aproximada de duas áreas de deposição de resíduos sólidos, atualmente ocupadas

Fonte: Google Earth - imagens 2009

A utilização de terrenos que no passado foram objeto de deposição de resíduos ocorre, na maior parte das vezes, por formas de ocupação irregular e precária. Entretanto, em algumas ocasiões, esta utilização acontece por meio de edificações regulares, como no conhecido caso do condomínio residencial Barão de Mauá, localizado no Parque São Vicente, município de Mauá - SP.

De acordo com informações constantes da página da internet da CETESB, o condomínio residencial Barão de Mauá foi erguido sobre uma área pertencente à empresa Cofap, que foi aterrada com resíduos compostos principalmente por areias de fundição, além de outras substâncias tóxicas de origem desconhecida, por falta de controle dos proprietários. A Figura 2, a seguir, constante da referida página, demonstra que parte das edificações foi implantada sobre a área aterrada. 


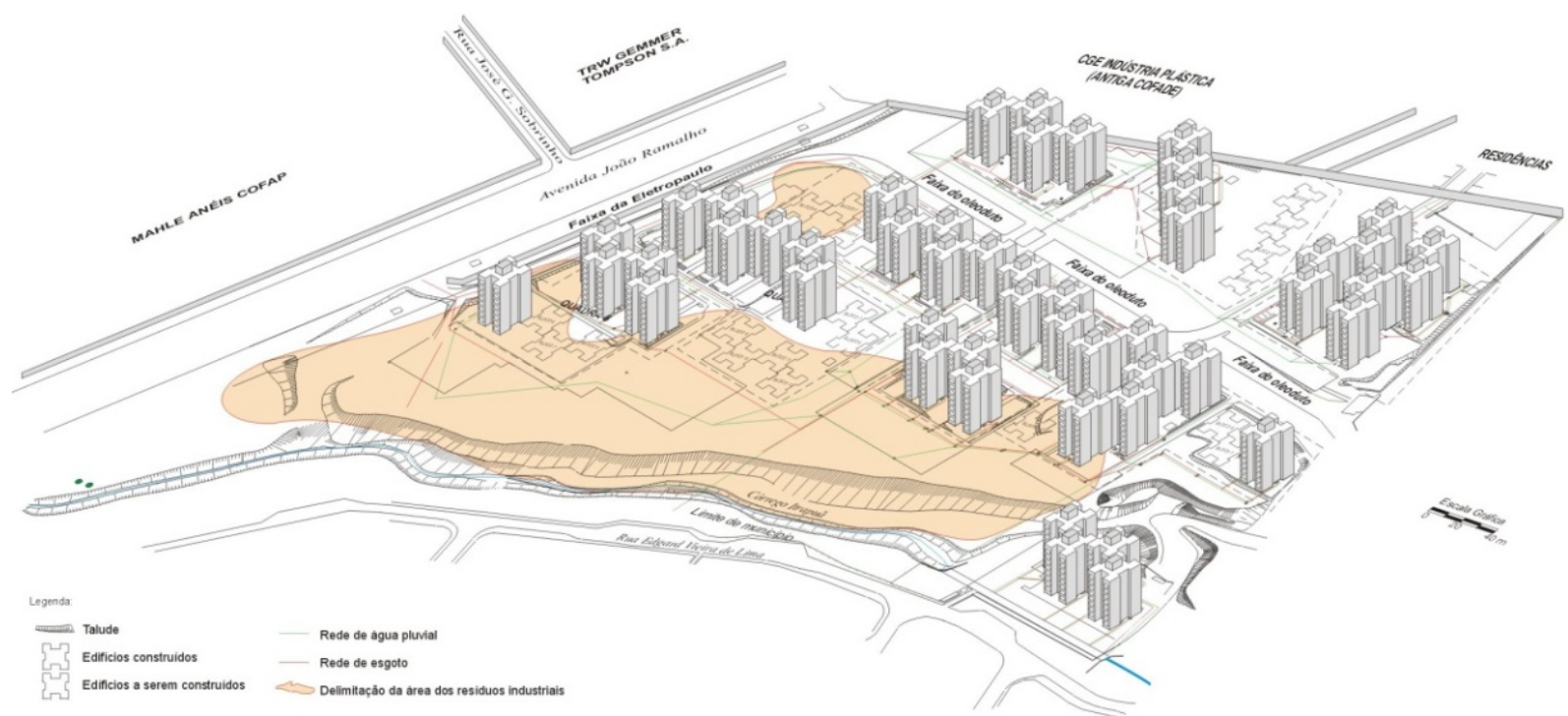

Figura 2 - Perspectiva da área do condomínio Barão de Mauá Fonte: Página da internet da CETESB

A ocorrência de uma explosão causada pelo acúmulo de gases produzidos pelo aterro no ano de 2000 , durante trabalhos de manutenção numa das caixas d'água subterrâneas, resultou na morte de um trabalhador e, a partir de então, a CETESB passou a acompanhar o caso, aplicando inicialmente uma multa à construtora responsável e impondo a adoção de uma série de medidas relativas ao monitoramento, identificação, caracterização e remediação do solo e águas subterrâneas.

A CETESB informa que, com a implementação das ações exigidas, a situação emergencial e os riscos decorrentes da inalação do ar encontram-se sob controle, permanecendo as atividades de monitoramento da área. Ainda de acordo com a companhia, por determinação do Ministério Público Estadual, em agosto de 2009 foram concluídos os trabalhos de perfuração e coleta de amostras visando à realização de um novo diagnóstico a respeito da contaminação, cujos relatórios foram entregues à CETESB em abril de 2010.

No campo judicial, no entanto, as ações se arrastam, prolongando o drama de dezenas de famílias que tiveram uma vertiginosa desvalorização de seu patrimônio e esperam há mais de dez anos por uma decisão favorável ao pagamento de indenizações.

Embora o problema no Condomínio Barão de Mauá tenha sido constatado em 2000, revelando então o despreparo da maioria dos municípios para lidar com a questão, tendo em vista que neste caso a obra havia sido autorizada pela Prefeitura 
local, a realidade é que ainda hoje não é dada a devida importância a um tema que pode ter graves implicações sobre o meio ambiente, a saúde pública e a vida pessoal daqueles que são afetados pelo problema.

Outro caso conhecido pelos profissionais que atuam na área, o qual também vem sendo objeto de acompanhamento pela CETESB, é o do Shopping Center Norte, que retornou ao noticiário por meio de reportagem do jornal Folha de São Paulo, de 17/09/2011, dando conta de que o órgão ambiental estadual teria ameaçado interditar o empreendimento, caso não fosse realizado o controle do acúmulo de gás metano no subsolo.

Sabe-se que a região sobre a qual foi implantado o shopping center, em 1984, era um antigo meandro do rio Tietê, antes de sua retificação, que foi utilizado pela Prefeitura como lixão nos anos 1960. A citada reportagem revela que a área passou a ser investigada em 2004, sendo que os primeiros alertas para que o shopping realizasse obras para a exaustão do gás haviam sido feitos há cerca de três anos. Ainda em julho de 2010, medições realizadas pela CETESB identificaram níveis críticos de concentração do gás que poderiam se infiltrar no ambiente interno da edificação, por meio de trincas no piso e galerias, ou mesmo por vãos entre o piso e as colunas. $\mathrm{Na}$ realidade, a ameaça representada pela presença do metano está relacionada ao risco de explosividade, principalmente quando confinado em pequenos ambientes, situação em que qualquer agente detonador pode provocar explosão.

Situação semelhante é encontrada no novo Campus Leste da Universidade de São Paulo, que foi implantado sobre uma área de preservação permanente, na várzea do rio Tietê, onde houve disposição de resíduos no passado, o que resultou na geração de metano, obrigando a instalação de um sistema de captação de gases. O episódio ilustra mais uma vez o desconhecimento ou o descaso na tomada de determinadas decisões na esfera pública e, periodicamente, o assunto volta à tona, com se observa nas reportagens do jornal "Folha de São Paulo", de 17 de novembro de 2011 e 17 de abril de 2012, que demonstraram a existência, na época, de providências ainda pendentes.

Recentemente, uma grande área desocupada na região de Pirituba, de propriedade da Companhia City, inicialmente cogitada para a construção do novo estádio para a abertura da Copa do Mundo de Futebol em 2014, também revelou a 
existência de um pequeno trecho com contaminação do solo e das águas subterrâneas, fato divulgado pela imprensa e confirmado pela CETESB.

Trata-se de uma contaminação restrita a uma área que havia sido utilizada pela Pedreira Universo, até 1996, para a deposição de resíduos industriais de areia de fundição, material que contém metais pesados. O local está cadastrado na Relação de Áreas Contaminadas e Reabilitadas no Estado de São Paulo, atualizada em dezembro de 2010 pela CETESB e, de acordo com as informações constantes naquela relação, encontra-se na etapa de gerenciamento correspondente à "remediação com monitoramento da eficiência e eficácia", tendo sido adotada como medida de remediação a cobertura de resíduo/solo contaminado, o que contraindicaria a implantação de edificações naquela porção do terreno e recomendaria a análise técnica do restante do terreno.

Esta área, juntamente com outras adjacentes que totalizam mais de cinco milhões de metros quadrados, já foi declarada como de utilidade pública pelo Município, para a implantação de um grande centro de exposições e eventos para sediar a Exposição Mundial de 2020, cuja candidatura é pleiteada pela cidade. A foto 25 evidencia a existência de massas significativas de vegetação e cursos d'água no interior do terreno, razão pela qual ele é parcialmente enquadrado como Zona Especial de Proteção Ambiental (ZEPAM) pelo zoneamento municipal em vigor, enquanto a parcela pertencente à Companhia City é enquadrada como Zona Exclusivamente Residencial de Média Densidade (ZER 2). As ilustrações abaixo, publicadas no portal da internet da Prefeitura de São Paulo, na página da Subprefeitura de Pirituba/Jaraguá, em 21/01/2011, demonstram a dimensão do empreendimento previsto para a área, denominado Expo São Paulo, permitindo desde já antever o nível de impactos esperados com a sua instalação (Figuras 3 e 4). 


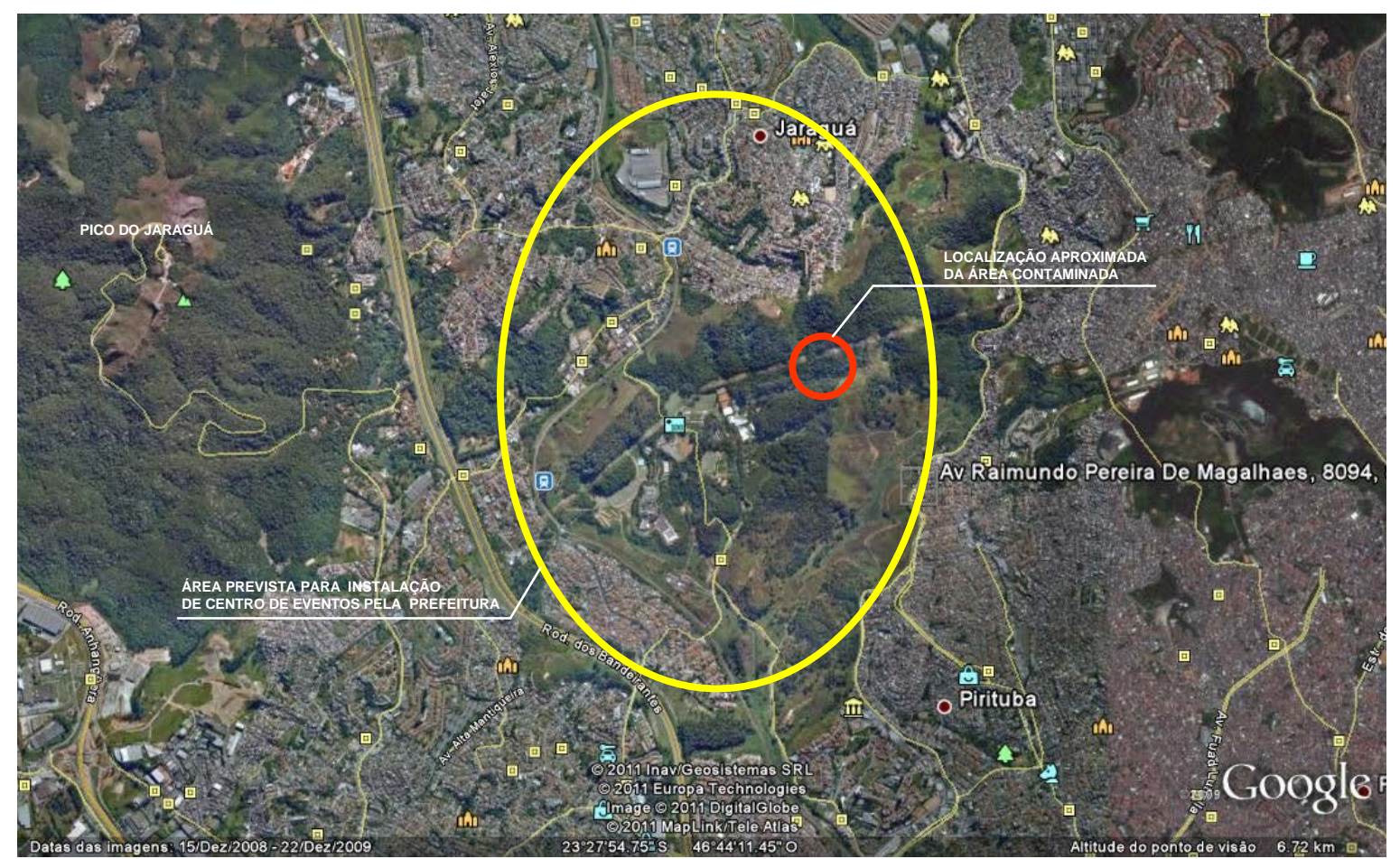

Foto 25 - Foto aérea da região prevista para a instalação da Expo São Paulo, em Pirituba

Fonte: Google Earth - imagens 2009

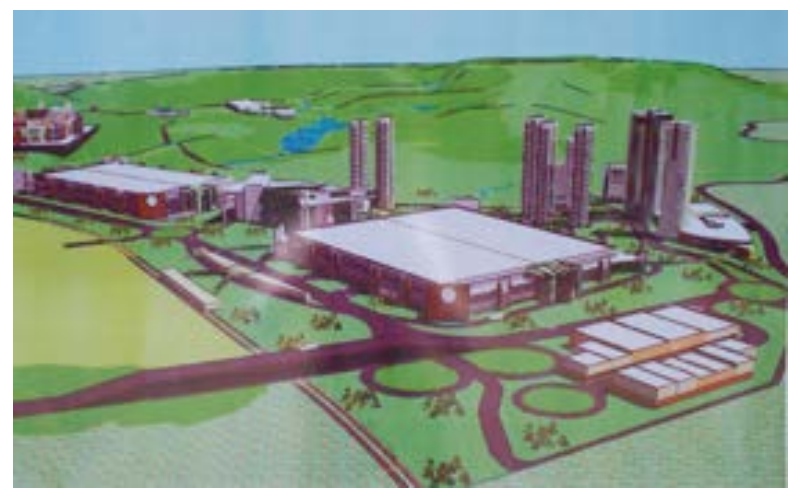

Figura 3 - Expo São Paulo - perspectiva geral do Figura 4 - Expo São Paulo - área de hotéis empreendimento

Fonte: Página da internet da Subprefeitura Pirituba/Perus - Portal da Prefeitura do Município de S.Paulo

No que diz respeito aos aterros de resíduos sólidos desativados, a atuação do poder público municipal expõe a adoção de procedimentos contraditórios.

O futuro Parque Sapopemba (Foto 26) encontra-se em fase de implantação sobre o antigo aterro de resíduos sólidos de mesmo nome, como parte das compensações ambientais pelo licenciamento ambiental da Central de Tratamento de Resíduos (CTR) Leste, sob responsabilidade da concessionária de serviços Ecourbis, recebendo também recursos do Fundo Especial do Meio Ambiente e Desenvolvimento Sustentável (FEMA). A CTR, recentemente instalada na região de 
São Mateus, zona leste do município, sucede o aterro São João, que teve a sua capacidade esgotada.

Neste caso, as diretrizes iniciais para a elaboração do projeto do parque haviam sido fixadas pela Secretaria Municipal das Subprefeituras, revelando uma duplicidade de competências com o Departamento de Parques e Áreas Verdes (DEPAVE), da Secretaria do Verde e do Meio Ambiente. Na realidade, em um determinado momento, por volta de 2006, a Administração Municipal decidiu criar um núcleo específico para tratar de questões relacionadas a áreas verdes no gabinete da referida secretaria, que também passou a elaborar projetos de parques municipais, atribuição legal do DEPAVE. Deve-se ressaltar que o gerenciamento de áreas contaminadas no Município de São Paulo compete ao Grupo Técnico Permanente de Áreas Contaminadas (GTAC), da Secretaria do Verde e do Meio Ambiente.

Ao final, como mencionado anteriormente, a elaboração do projeto do parque coube à empresa Ecourbis, por conta das compensações ambientais do CTR, com o acompanhamento do DEPAVE, fato que evidencia o encadeamento de ações desconexas, no âmbito da Administração Pública, que invariavelmente acabam por dificultar a execução de projetos que deveriam permitir a integração de diferentes áreas do conhecimento.



Foto 26 - Área do antigo aterro de resíduos de Sapopemba, onde se pretende instalar um parque municipal

Fonte: Google Earth - imagens 2009 
Outro parque a ser implantado sobre um aterro de resíduos sólidos é o Primavera, localizado na região de Ermelino Matarazzo, zona leste da cidade, junto ao córrego Jacuí e à Avenida Jacu-Pêssego (Fotos 27 a 30). O aterro era uma antiga cava de exploração de areia, que passou a receber resíduos coletados pela Prefeitura a partir de 1981 e teve as suas atividades interrompidas em 1983 por pressão da população local, quando foi firmado um acordo no qual o poder público se comprometeu a converter o lixão em um aterro controlado. Antes do encerramento da operação do aterro, em 1988, constatou-se a migração de gases produzidos pela decomposição da massa de resíduos para residências do entorno, o que provocou a ocorrência de uma explosão e o ferimento de alguns moradores. Naquela ocasião foi providenciada a construção de drenos de gases mais profundos e de um sistema de exaustão forçada de gases, conforme orientação da CETESB.

Durante as investigações promovidas pelo GTAC, com o objetivo de realizar uma avaliação ambiental do local visando subsidiar a elaboração do projeto do parque, cerca de dezoito anos após o encerramento do aterro, foi verificada a presença de gases nos drenos instalados em uma residência próxima ao aterro, não sendo possível, porém, precisar a sua origem. Embora não tivessem sido detectadas emissões significativas de gases nos drenos existentes, a opção pela instalação de um sistema de drenagem de gases na área de disposição dos resíduos foi definida como uma medida preventiva a ser adotada como uma das diretrizes para ocupação daquele espaço. Contudo, mudanças sucessivas no posicionamento jurídico quanto à forma de licitação para a implantação de tal sistema foram postergando a sua realização.

Há mais de vinte anos, o DEPAVE, anteriormente vinculado à Secretaria de Serviços e Obras, já havia desenvolvido projeto de parque para o local, sem a realização de estudos específicos sobre a contaminação. Os estudos iniciais do projeto do parque Primavera, considerando as avaliações ambientais promovidas pelo GTAC, foram efetuados por este autor durante o período em que atuou na divisão de projetos do DEPAVE, atualmente parte da Secretaria do Verde e do Meio Ambiente, entre 2007 e 2008. Com a finalidade de iniciar o processo de implantação do parque, independentemente da instalação do sistema de drenagem de gases, decidiu-se dividir o projeto em duas etapas, a primeira delas numa porção do terreno 
que não havia sido utilizada para a deposição de resíduos e a segunda no aterro propriamente dito.

A execução das obras da primeira etapa do projeto, sobre a área de deposição de resíduos propriamente dita, chegou a ser temporariamente paralisada, em função da verificação da existência de chorume numa caixa de concreto encontrada sob a laje de sustentação da antiga estação de tratamento de esgotos, sendo posteriormente retomada.

Os estudos elaborados para a segunda fase do projeto previam a instalação de um sistema de drenagem de gases, assim como a manutenção dos drenos construídos à época do funcionamento do aterro e do bosque de eucaliptos, sobre o solo que recobre a massa de resíduos, que poderiam ser gradativamente substituídos por outras espécies arbóreas, conforme plano de manejo a ser estudado pela divisão do DEPAVE responsável pela manutenção dos parques municipais. Previa-se também o recobrimento com solo novo de uma área sem vegetação de porte arbóreo, onde se constatou a presença de contaminantes no solo existente, para a instalação de um espaço multiuso reivindicada pela população local. Informações obtidas por meio de técnicos que atualmente trabalham na área dão conta de que se pretende promover alterações no projeto, porém espera-se que as diretrizes básicas, levando-se em consideração os aspectos relativos à contaminação, sejam mantidas para se garantir o uso seguro do espaço pelo público.

Há que se frisar que a concepção de projetos de áreas verdes sobre aterros de resíduos sólidos não se resumem a aspectos meramente estéticos e funcionais e nem à mera seleção de espécies vegetais, pois envolve uma série de questões que o tornam complexo, configurando-o como um trabalho essencialmente interdisciplinar, que implica necessariamente a interlocução entre diferentes campos do conhecimento. 


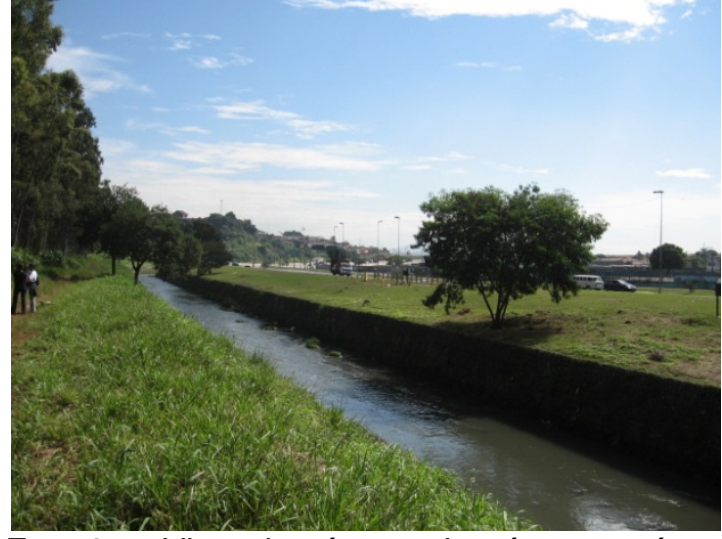

Foto 27 - Vista do córrego Jacuí, com a área do parque Primavera, à esquerda, e a av. Jacu-Pêssego, à direita

Foto do autor

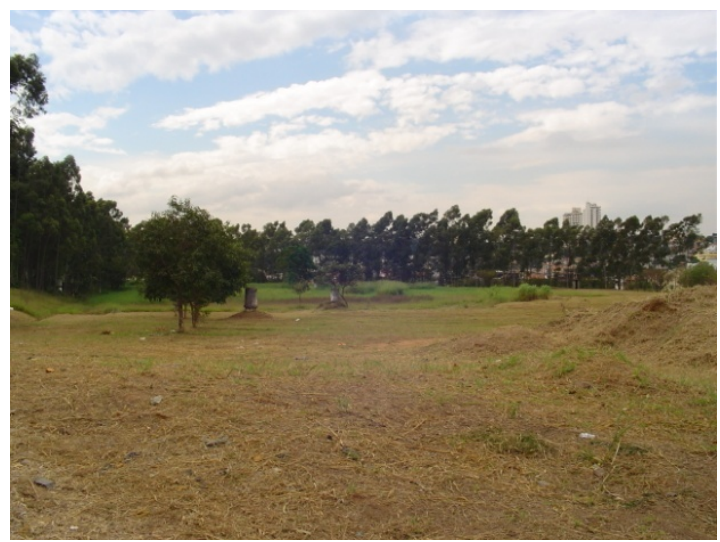

Foto 29 - Vista interna da porção do parque sem vegetação de porte arbóreo, com constatação de contaminação no solo

Foto do autor

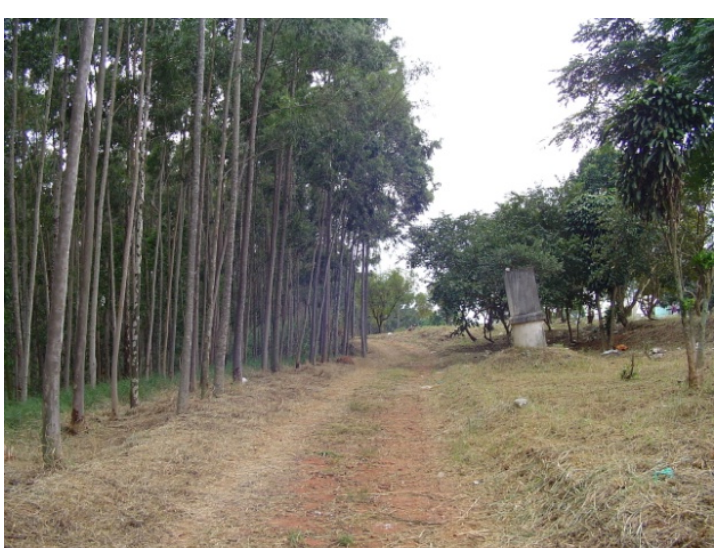

Foto 28 - Vista interna da área do parque com o bosque de eucaliptos, à direita, e um dos drenos de gases, à esquerda

Foto do autor

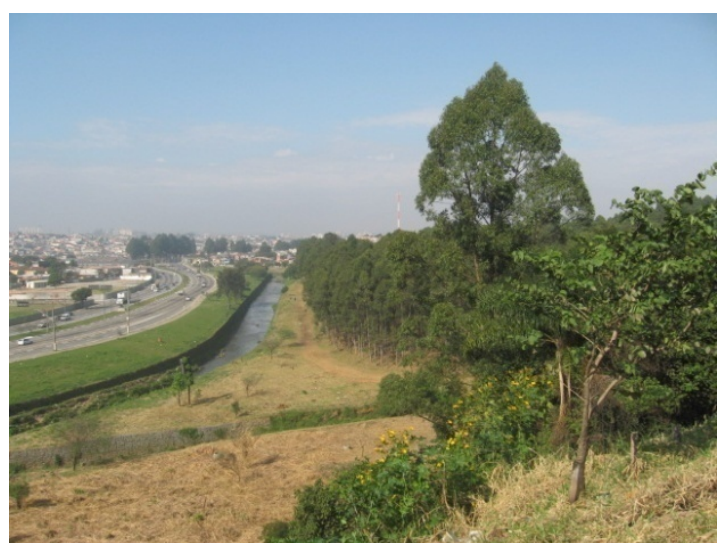

Foto 30 - Vista geral da área do parque, à direita, e do córrego Jacuí e da av. JacuPêssego, à esquerda

Foto do autor

A praça Vitor Civita é um exemplo recente de parceria público-privada entre a Prefeitura e a Editora Abril, que viabilizou a recuperação de uma área contaminada com aproximadamente $16.000 \mathrm{~m}^{2}$, onde funcionou um incinerador de resíduos sólidos no período entre 1949 e 1989, na rua do Sumidouro, bairro de Pinheiros (Fotos 31 a 36). 


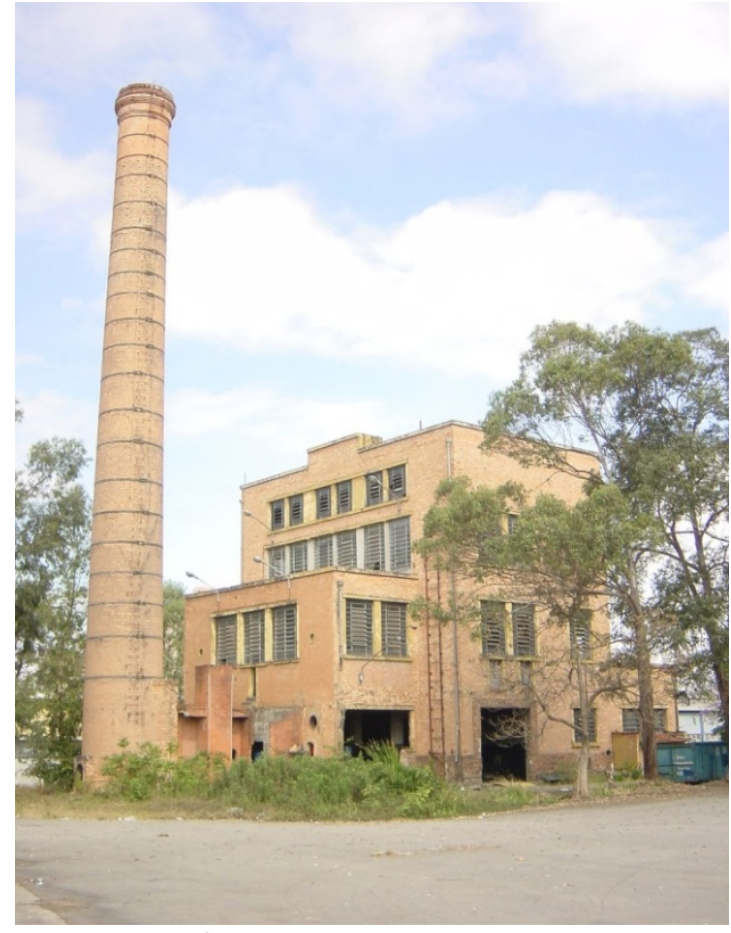

Foto 31 - Edificação do antigo incinerador

Fonte: Secretaria do Verde e do Meio Ambiente

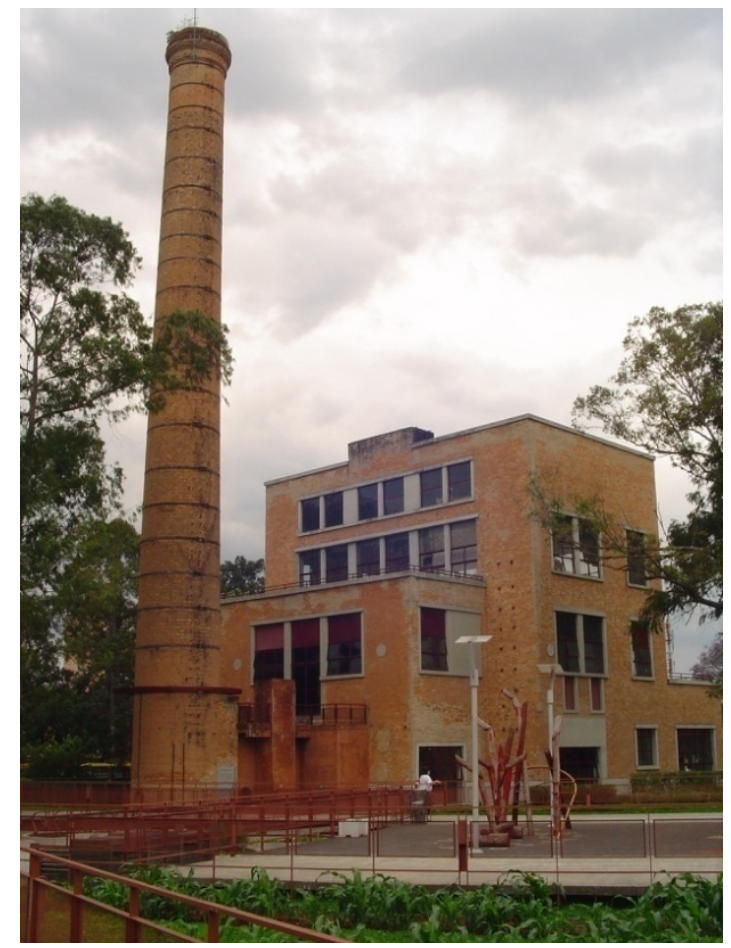

Foto 33 - Praça Vitor Civita com edificação do antigo incinerador

Foto do autor

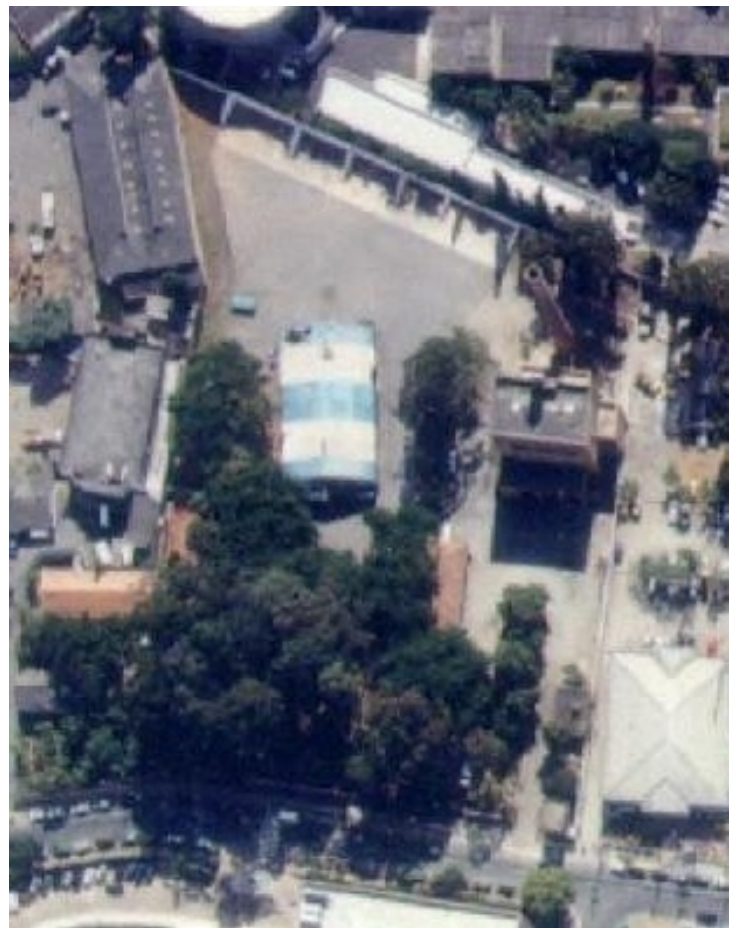

Foto 32 - Vista aérea da área do incinerador

Fonte: Secretaria do Verde e do Meio Ambiente



Foto 34 - Praça Vitor Civita com sede da Editora Abril ao fundo

Foto do autor 


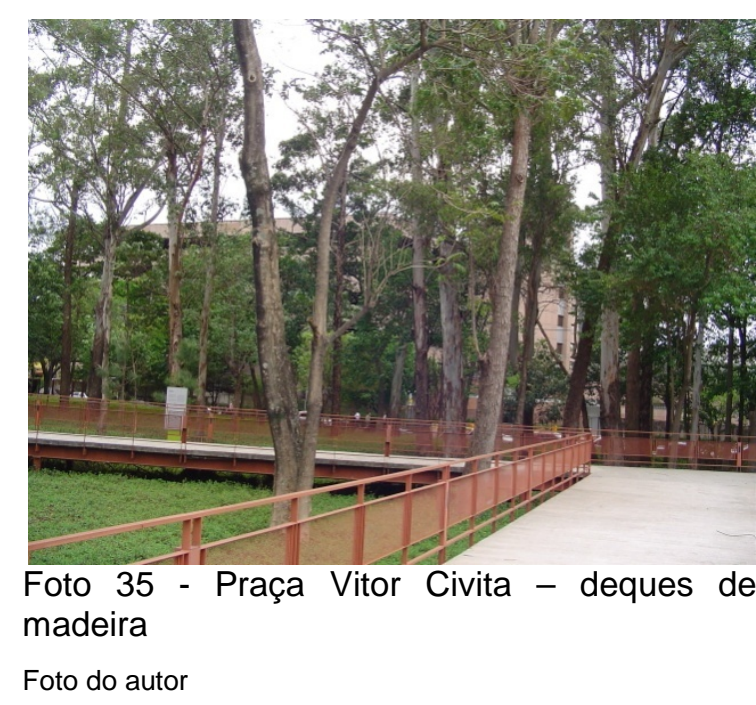

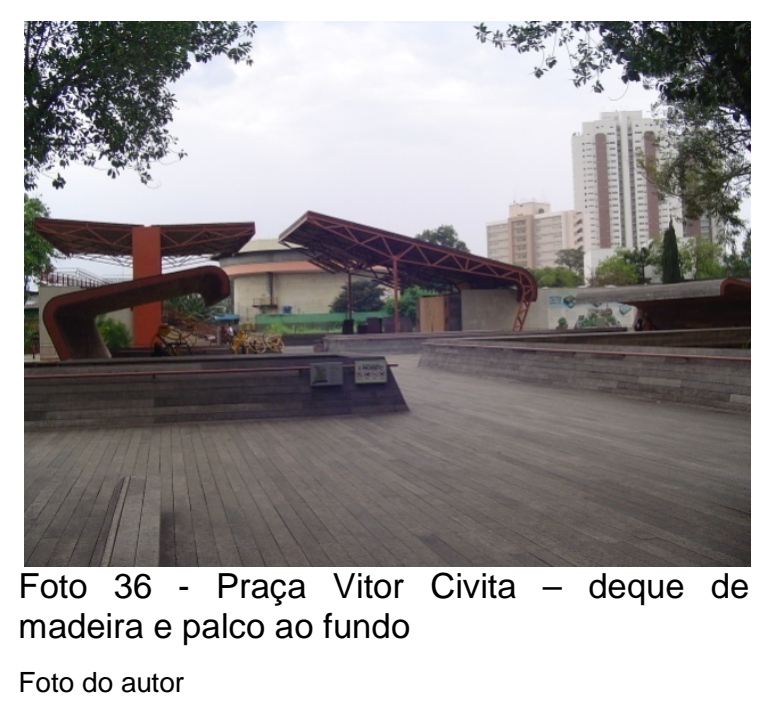

Foto do autor

As primeiras investigações para se avaliar o nível de contaminação existente na área foram realizadas por iniciativa da Secretaria do Verde e do Meio Ambiente, que tinha a proposta de implantar um parque público naquele local.

Durante a época de funcionamento do incinerador, as cinzas resultantes do processo de queima dos resíduos foram depositadas nas proximidades das suas instalações, o que justifica a presença de metais pesados no solo. No interior da edificação principal foram constatados níveis de dioxinas e furanos, consideradas substâncias cancerígenas, em concentrações acima dos padrões de intervenção, de acordo com os parâmetros constantes da regulamentação da lei federal alemã de Proteção de Solo e de Águas Contaminadas, de 1999.

Os entendimentos visando à parceria público-privada tiveram início após 2006 entre a empresa interessada, que tem sua sede localizada defronte ao terreno do incinerador, e a Secretaria do Verde e do Meio Ambiente, com participação da Subprefeitura de Pinheiros e da agência alemã de cooperação técnica Deutsche Gesellschaft für Technische Zusammenarbeit (GTZ). Com a opção da Administração Municipal de conduzir o projeto por meio de um termo de cooperação para recuperação e conservação de praça, a coordenação dos trabalhos foi assumida pela Subprefeitura, cabendo à Secretaria do Verde e do Meio Ambiente apenas o acompanhamento das questões relativas à contaminação, em conjunto com a CETESB.

O projeto arquitetônico e paisagístico, contratado pela Editora Abril, adotou como solução a utilização de grandes deques de madeira sustentadas por estruturas 
metálicas sobre a área externa à edificação principal, cuja superfície foi recoberta com uma camada de solo como mecanismo para impedir o contato com o material contaminado, enquanto que as superfícies internas do incinerador foram raspadas, para dar lugar ao Museu da Sustentabilidade.

Para coordenar a implantação da "praça" e realizar a sua gestão foi criada em 2007 uma Organização da Sociedade Civil de Interesse Público (OSCIP), o Instituto Abril. O termo firmado com a Prefeitura fixa o prazo de sua vigência da parceria em vinte anos, com prorrogação automática por igual período, cabendo à Editora Abril a reabilitação da área, bem como a elaboração e a implantação de projeto, conforme diretrizes fornecidas pela Municipalidade, além da realização dos serviços de limpeza e manutenção por um período mínimo de dois anos, após a implantação do projeto, e da doação ao Município dos serviços e obras executados. A Editora Abril obriga-se também a promover atividades gratuitas de lazer, esporte e cultura em conjunto com a Prefeitura ou com sua anuência.

Embora reconhecendo a visibilidade trazida ao local pela implantação do empreendimento, a busca pela viabilização de parcerias público-privadas, motivada por uma suposta incapacidade do poder público de arcar com os custos de projetos de interesse da população, tem levado à crescente perda de oportunidades para a realização de projetos integrados e conduzidos por equipes permanentes da própria Administração. Neste caso, poderia ter sido considerada a possibilidade de se aliar a questão da recuperação da área contaminada ao desenvolvimento de um projeto experimental de pesquisa e remediação de longo prazo, por meio da utilização de técnicas como a fitorremediação.

Não obstante a solução arquitetônica arrojada adotada no projeto do espaço em questão, há que se considerar que as obras existentes no local passarão a fazer parte do patrimônio municipal, cabendo à Prefeitura, em algum momento, o custeio da realização da manutenção da área.

No ano de 2007, a CETESB instituiu a categoria de "Áreas Contaminadas Críticas", nas quais se inserem aquelas que exigem um procedimento de gerenciamento diferenciado, em razão dos danos causados ou dos riscos que representam, gerando inquietação na população ou conflitos entre os atores envolvidos. 
Uma das regiões enquadradas nesta categoria é a de Jurubatuba, na Subprefeitura de Santo Amaro, zona sul do Município, que abrange uma antiga zona industrial, atualmente em processo de transformação de uso, com a instalação de diversos condomínios residenciais de alto padrão. Com a desativação de diversas unidades fabris, a CETESB iniciou uma série de procedimentos visando à investigação de passivos ambientais e, em 2001, a empresa Gillette do Brasil Ltda., por meio de autodenúncia, informou a existência de contaminação do solo e das águas subterrâneas em seu terreno, que acabara de adquirir da empresa Duracell, fabricante de pilhas e baterias. A constatação de que as plumas de contaminação haviam extrapolado os limites da indústria suscitaram a ampliação da área de investigação.

De acordo com informações constantes da página da internet da CETESB, a partir da confirmação da contaminação do aquífero mais profundo por um novo relatório apresentado pela Gillette, em 2004, as investigações passaram a abranger a região da antiga Zona de Uso Predominantemente Industrial (ZUPI 131), estabelecida pela legislação estadual, num raio de quinhentos metros, revelando a contaminação generalizada da água subterrânea profunda naquela localidade, provavelmente ocasionada também por outras fontes de contaminação. Como consequência, houve o fechamento de todos os poços contaminados e a edição de uma portaria criando uma "Área de Restrição e Controle Temporário" da água subterrânea.

Assim como outras antigas áreas industriais na cidade de São Paulo, a região de Jurubatuba vem perdendo progressivamente a sua vocação fabril e ganhando novos usos e novas construções, o que requer a adoção de medidas de precaução tendo em vista a existência de contaminação no solo e nas águas subterrâneas.

Um caso atual de tentativa de reutilização de área contaminada pelo poder público estadual foi relatado no Portal UOL, em 11 de janeiro de 2013, e refere-se à intenção de se implantar um piscinão em área de propriedade da Sabesp, junto à favela da Vila Prudente, que serviu como depósito de lixo orgânico e industrial no passado, causando a contaminação do solo e da água subterrânea. Na reportagem, o promotor que acompanha o problema afirma que há dez anos o Ministério Público Estadual vem tentando fazer com que a SABESP atenda às exigências da CETESB, no que diz respeito à contaminação, motivo pelo qual a instituição entrou com uma 
ação civil contra a empresa, suspendendo as obras do piscinão. A matéria ainda alerta para a existência de um Centro de Detenção Provisória e de um shopping center, na área em que se pretende construir o piscinão, e lembra que em 2004 uma outra ação do Ministério Público Estadual contra a SABESP resultou na remoção das favelas Paraguai e da Paz, além de uma creche, com base em laudos técnicos da CETESB que revelavam riscos à vida da população local, porém sem que providências quanto à remediação da contaminação do terreno tivessem sido tomadas. Observa-se, neste exemplo, a repetição de uma prática constante na administração pública, resultante mais uma vez da atuação fragmentada dos seus diferentes entes e da tomada de decisões equivocadas que implicam elevados custos sociais e econômicos.

No estado de São Paulo, e certamente no Brasil, os primeiros casos de áreas contaminadas foram tratados pela CETESB que, em conjunto com a agência de cooperação técnica alemã GTZ, formularam os procedimentos visando à identificação, investigação e remediação que têm orientado a formulação de políticas neste tema. Durante vários anos esta tarefa coube exclusivamente à CETESB, porém a partir do momento em que os municípios passaram a assumir com mais efetividade a responsabilidade pelos assuntos de interesse local, conforme estabelecido pela Constituição Federal, e os temas ambientais começaram a adquirir maior relevância, as áreas contaminadas também começaram a fazer parte do rol das preocupações do nível municipal, ao qual competem as questões relativas ao uso e à ocupação do solo.

É justamente no campo das competências entre diferentes níveis de governo, e mesmo entre diferentes órgãos do mesmo nível de governo, que surgem os conflitos, uma vez que o mesmo problema é encarado sob enfoques distintos e nem sempre complementares.

Como exemplo deste fato pode ser citada a Lei Estadual no 9.999/98, ainda em vigor, a qual estabelece que nas ZUPI "poderão ser admitidos os usos residencial, comercial, de prestação de serviços e institucional, quando se tratar de zona que tenha sofrido descaracterização significativa do uso industrial e não haja contaminação da área, mediante parecer técnico do órgão ambiental estadual, desde que o uso pretendido seja permitido pela legislação municipal." Reconhecendo as alterações de uso substanciais verificadas em regiões 
classificadas como Z6 (uso predominantemente industrial) e Z7 (uso estritamente industrial) pelo zoneamento vigente anteriormente, o Plano Diretor Estratégico do Município de São Paulo aprovado em 2002, assim como os Planos Regionais Estratégicos aprovados em 2004, promoveram o reenquadramento de várias delas como Zonas Mistas. Até poucos anos atrás, embora houvesse o entendimento entre os setores técnicos dos órgãos ambientais estadual e municipal de que o parecer técnico exigido pela Lei $n^{\circ}$ 9.999/98 seria dispensável, diante da nova legislação municipal, o setor jurídico da CETESB não tinha a mesma compreensão sobre a questão, trazendo dificuldades à atuação do Município nesta área.

$\mathrm{Na}$ sua competência legal de legislar e atuar sobre os assuntos relacionados ao uso e à ocupação do solo, o Município tem entre as suas atribuições a aprovação de projetos de parcelamento do solo, assim como de edificações e mudanças de uso. Em São Paulo, esta tarefa é dividida, até o momento, entre as Secretarias Municipais de Habitação (SEHAB) e das Subprefeituras (SMSP), basicamente em função do tipo de atividade e do porte do empreendimento.

O Boletim de Dados Técnicos (BDT) é o cadastro de informações relativas aos imóveis oficialmente registrados, que orienta os órgãos municipais de aprovação em suas análises e, a partir de 2005, segundo Ramires (2008), passou a ser alimentado pelo GTAC com dados referentes à contaminação. A reunião das informações a respeito de imóveis classificados segundo as categorias de potencialmente contaminados, suspeitos de contaminação e comprovadamente contaminados deu origem ao Sistema de Informação de Gerenciamento de Áreas Contaminadas (SIGAC), que atualmente encontra-se interligado ao BDT.

As solicitações de aprovação de projetos são realizadas junto aos órgãos de aprovação que, por sua vez, são transformadas em processos e, quando envolvem questões específicas, podem ser encaminhados aos setores competentes da Municipalidade para emissão de pareceres. Na hipótese de contaminação do solo e das águas subterrâneas, os processos provenientes em sua maioria da SEHAB costumavam ser enviados ao GTAC, que adotava os procedimentos necessários de acordo com as etapas definidas no gerenciamento de áreas contaminadas.

Os casos analisados pelo GTAC, desde a sua constituição em 2003 até o ano de 2006, eram encaminhados à CETESB assim que a contaminação no imóvel era constatada, para que a análise tivesse prosseguimento naquela instituição, em 
razão de sua experiência e expertise no tema. Ramires (2008) informa que, com a qualificação de sua equipe técnica, a partir de 2007 o GTAC passou a assumir todas as etapas de investigação e acompanhamento dos imóveis abrangidos no âmbito da competência municipal.

Com o aumento significativo do volume da demanda de análises sobre contaminação, processos específicos começaram a ser autuados na Secretaria do Verde e do Meio Ambiente, separadamente dos processos de aprovação dos empreendimentos, na tentativa de agilizar a tramitação burocrática, muito embora alguns deles ainda continuem a ser encaminhados via órgãos de aprovação. Neste procedimento, a iniciativa da autuação parte do próprio empreendedor, algumas vezes mediante prévia consulta ao GTAC, o que já demonstra a percepção por parte do setor imobiliário da necessidade de submeter projetos em terrenos com potencial de contaminação à análise do órgão ambiental e, segundo informações do GTAC, em diversas situações o interessado dá inicio ao processo investigativo, mesmo antes de entrar com a solicitação de análise do projeto. Uma alteração verificada na atual metodologia de avaliação desses imóveis diz respeito ao tratamento dado às áreas potencialmente contaminadas, que anteriormente só se tornavam objeto de investigação confirmatória se houvesse a constatação de indícios que apontassem para a suspeita de contaminação no terreno. Atualmente, o GTAC já requer a realização da investigação confirmatória, assim que há a constatação de que se trata de uma área com potencial de contaminação.

Diferentemente da análise circunscrita aos aspectos relacionados ao uso e à ocupação do solo, que se baseiam em regras claramente fixadas em legislação, o exame de áreas contaminadas é realizada praticamente caso a caso, devido às especificidades do problema e ao comportamento próprio da contaminação existente em cada local. Tal particularidade pode gerar conflitos com os setores de aprovação, da mesma forma que com os proprietários de imóveis, os empreendedores imobiliários e, eventualmente, com a própria Administração, quando projetos prioritários do ponto de vista político estão envolvidos.

Outra situação que ainda provoca muita insegurança diz respeito às contaminações causadas por fontes externas ao lote, muito comum nos casos em que a pluma de contaminação extrapola os limites do terreno de onde ela se origina. Assim, o proprietário de um lote vizinho afetado por esta pluma, que 
tivesse a intenção de aprovar um projeto de edificação, reforma ou mudança de uso encontraria sérias dificuldades, visto que a legislação em vigor não prevê esta condição, e a opção neste caso provavelmente recairia sobre a via judicial, com o objetivo de obrigar o proprietário ou possuidor do imóvel causador do problema a efetuar a investigação e a remediação da contaminação, o que poderia demandar alguns anos. Veja-se o caso do Parque Municipal Leopoldina/Villas-Boas que foi parcialmente inaugurado em 2010, em razão de parte da área, anteriormente ocupada pela usina de compostagem de Vila Leopoldina, estar comprometida por contaminação causada por uma antiga indústria desativada e demolida para a construção de um edifício, situada em terreno localizado a montante.

As Zonas Especiais de Interesse Social (ZEIS), definidas pelo Plano Diretor Estratégico e destinadas, "prioritariamente, à recuperação urbanística, à regularização fundiária e produção de Habitações de Interesse Social - HIS ou do Mercado Popular - HMP", apresentam outra faceta da questão das áreas contaminadas, relativa à localização de algumas das ZEIS exatamente em regiões que tiveram grande atividade industrial no passado ou que ainda a mantém com um certo grau de intensidade (Foto 37). A comparação entre os perímetros das antigas Zonas de Uso Predominantemente Industrial, estabelecidas pela legislação estadual, e as Zonas de Uso definidas pelo Plano Diretor Estratégico do Município em vigor demonstra a existência de sobreposição entre ambas em determinadas Subprefeituras, nas quais ainda ocorre uma atividade fabril remanescente, herdada do processo inicial de industrialização da cidade, como na Vila Maria (Figura 5, na Mooca (Figura 6) e no Ipiranga (Figura 7).

É importante lembrar que eventuais custos adicionais necessários à realização de investigações e à remediação da contaminação poderiam inviabilizar a implantação de empreendimentos de habitação de interesse social nas áreas enquadradas como ZEIS. 


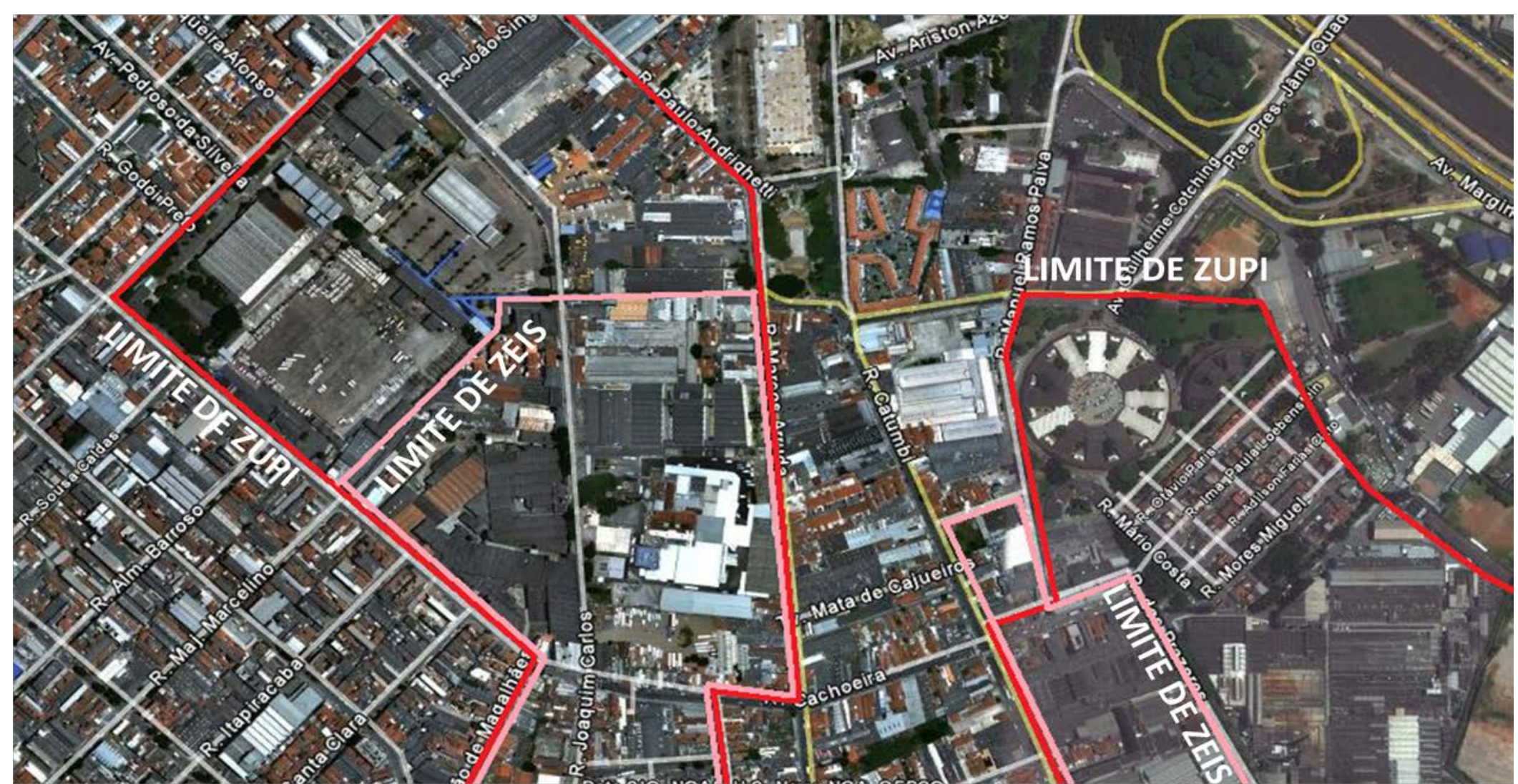

Foto 37 - Foto aérea da Subprefeitura da Mooca, indicando a existência de Zonas Especiais de Interesse Social - ZEIS em antigas áreas industriais (ZUPI)

Fonte: Google Earth - imagens 2009 


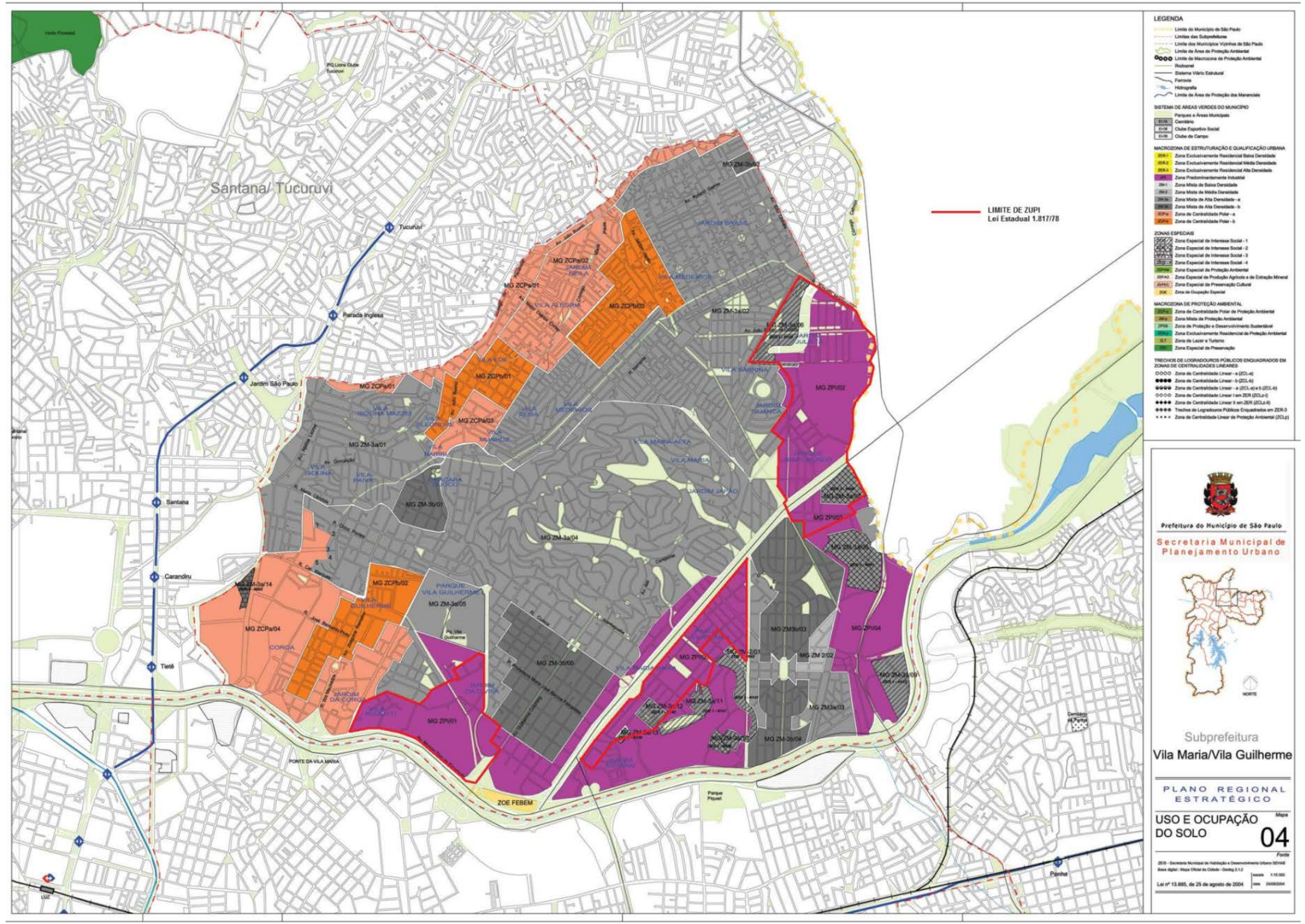

Figura 5 - Plano Regional Subprefeitura Vila Maria/Vila Guilherme e ZUPI's

Lei Municipal no 13.885/04 e Lei Estadual no $1.817 / 78$

Prefeitura

do

Município

de

São

Paulo.

Disponível

em:

<http://ww2.prefeitura.sp.gov.br/arquivos/secretarias/planejamento/zoneamento/0001/parte_II/v maria/07-MAPA-MG-04.jpg>. Acesso em: 10 out. 2010. (Montagem do autor) 

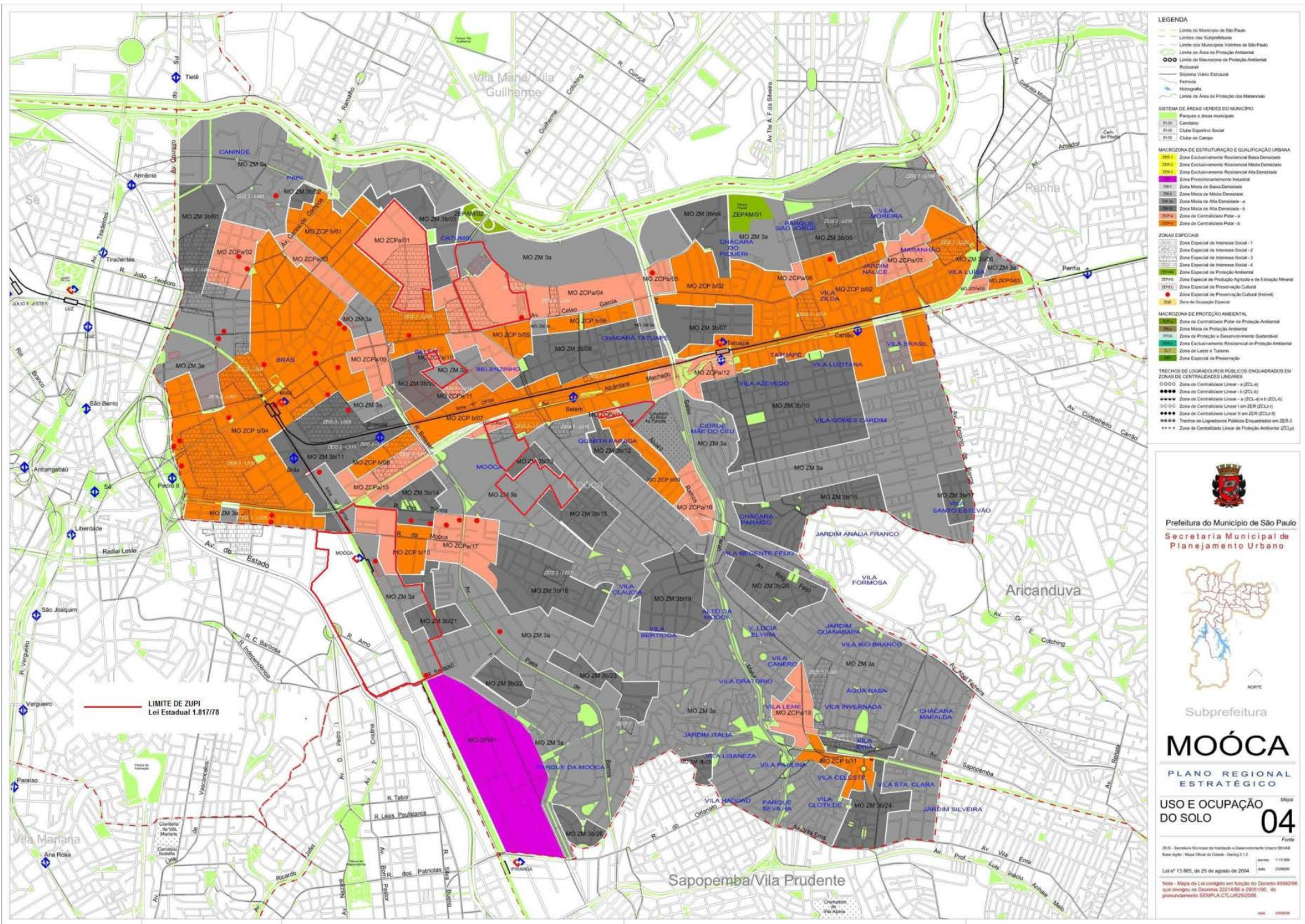

Figura 6 - Plano Regional Subprefeitura da Mooca e ZUPI's Lei Municipal no 13.885/04 e Lei Estadual no 1.817/78 Fonte: Prefeitura do Município de São Paulo. Disponível em: <http://sempla.prefeitura.sp.gov.br/urbanismo/arquivos/25MAPA-MO-04r1.jpg >. Acesso em: 10 out. 2010. (Montagem do autor) 




Figura 7 - Plano Regional Subprefeitura Ipiranga e ZUPI's

Lei Municipal no 13.885/04 e Lei Estadual no 1.817/78

Fonte: Prefeitura do Município de São Paulo. Disponível em: $<$ http://ww2.prefeitura.sp.gov.br//arquivos/secretarias/planejamento/zoneamento/0001/parte_Il/ipiranga/1 3-MAPA-IP-04.jpg >. Acesso em: 10 out. 2010. (Montagem do autor) 


\subsection{A Legislação pertinente}

A legislação nos níveis federal, estadual e municipal, tem incorporado gradativamente a problemática das áreas contaminadas, ainda que de forma pontual.

A aprovação da Política Nacional de Resíduos Sólidos, por meio da Lei Federal $n^{\circ} 12.305 / 10$, após anos de tramitação no Congresso Nacional, aborda o tema inicialmente no artigo 19, inciso XVIII, ao inserir no conteúdo mínimo do Plano Municipal de Gestão Integrada de Resíduos Sólidos a "identificação dos passivos ambientais relacionados aos resíduos sólidos, incluindo áreas contaminadas, e respectivas medidas saneadoras". Posteriormente, no Capítulo V - Dos Instrumentos Econômicos, o artigo 42 estabelece a possibilidade do poder público de "instituir medidas indutoras e linhas de financiamento", entre as quais a "descontaminação de áreas contaminadas, incluindo as áreas órfãs". Considera-se fundamental a inserção das áreas órfãs pelo referido dispositivo, justamente por se tratar dos terrenos nos quais o responsável não é passível de identificação, ou mesmo daqueles em que o responsável não possui recursos financeiros para suportar os custos necessários à investigação e remediação da contaminação, cabendo ao Estado assumir as providências quanto ao passivo existente nesses locais.

Ainda no âmbito federal, a Resolução CONAMA no 420/09 trata especificamente do assunto, dispondo sobre "critérios e valores orientadores de qualidade do solo quanto à presença de substâncias químicas" e estabelecendo diretrizes para o gerenciamento ambiental de áreas contaminadas originadas por atividades antrópicas.

Adiantando-se à Política Nacional de Resíduos Sólidos, em São Paulo, a Política Estadual de Resíduos Sólidos, instituída pela Lei no 12.300, de 16 de março de 2006, já estabelecia a atuação do poder público, em parceria com a iniciativa privada, visando "promover e exigir a recuperação das áreas degradadas ou contaminadas por gerenciamento inadequado dos resíduos sólidos mediante procedimentos específicos fixados em regulamento" como uma das medidas necessárias para alcançar os objetivos nela estabelecidos. A lei também cria os seguintes instrumentos, direcionados à remediação de áreas contaminadas por resíduos sólidos: 
- "o aporte de recursos orçamentários e outros, destinados prioritariamente às práticas de prevenção da poluição, à minimização dos resíduos gerados e à recuperação de áreas degradadas e remediação de áreas contaminadas por resíduos sólidos;

- os incentivos fiscais, tributários e creditícios que estimulem as práticas de prevenção da poluição e de minimização dos resíduos gerados e a recuperação de áreas degradadas e remediação de áreas contaminadas por resíduos sólidos".

Considerando, ainda, as características dos resíduos gerados "nas operações de emergência ambiental, em acidentes dentro ou fora das unidades geradoras ou receptoras de resíduo, nas operações de remediação de áreas contaminadas e os materiais gerados nas operações de escavação e dragagem", a referida lei determina que estes deverão ser previamente caracterizados, sendo posteriormente encaminhados para destinação adequada. Finalmente, com base no princípio do poluidor-pagador, estabelece que os geradores de resíduos de qualquer origem ou natureza, do mesmo modo que os seus sucessores e os gerenciadores das unidades receptoras serão "responsáveis pelos resíduos remanescentes da desativação de sua fonte geradora, bem como pela recuperação das áreas por eles contaminadas". Vale ressaltar que, neste caso, a inclusão dos sucessores está apoiada na concepção da responsabilidade objetiva, segundo a qual o poluidor fica obrigado "a indenizar ou reparar os danos causados ao meio ambiente e a terceiros, afetados por sua atividade", independentemente da existência de culpa, conforme consignado no art. 14 da Lei Federal $n^{\circ}$ 6.938/81, que instituiu a Política Nacional do Meio Ambiente.

Mais recentemente, o Estado de São Paulo aprovou a Lei $n^{\circ} 13.577$, de 8 de julho de 2009, que trata "da proteção da qualidade do solo contra alterações nocivas por contaminação, da definição de responsabilidades, da identificação e do cadastramento de áreas contaminadas e da remediação dessas áreas de forma a tornar seguros seus usos atual e futuro". De maneira acertada, a lei incluiu, entre os instrumentos para a implantação do sistema de proteção da qualidade do solo e o gerenciamento de áreas contaminadas, o Plano Diretor e legislação de uso e ocupação do solo, ambos de competência municipal.

Outro instrumento previsto por esta norma legal, o Cadastro de Áreas Contaminadas, composto por informações registradas nos órgãos públicos estaduais 
e municipais, classifica as áreas consideradas contaminadas em três classes, a saber:

- Classe Al - Área Contaminada sob Investigação;

- Classe AC - Área Contaminada;

- Classe AR - Área Remediada para Uso Declarado.

A classe de Área Remediada para Uso Declarado diz respeito aos locais anteriormente contaminados que, após sofrerem processo de remediação, tiveram restabelecido "o nível de risco aceitável à saúde humana, considerado o uso declarado". É importante lembrar que os projetos em áreas contaminadas estabelecem níveis de remediação, de acordo com o uso que se pretende instalar na área, e por esta razão novas intervenções físicas no imóvel, ou mesmo a sua mudança de uso, podem implicar a realização de novas avaliações relativas à contaminação.

No que se refere às obrigações quanto à prevenção, identificação e remediação de áreas contaminadas, verifica-se novamente a presença da responsabilidade objetiva ao tornar responsáveis legais e solidários o causador da contaminação e seus sucessores, o proprietário da área, o superficiário, o detentor da posse efetiva e aquele que dela se beneficiar direta ou indiretamente. Nas situações em que o responsável legal não realize a imediata remoção do perigo, admite-se que o poder público tome as providências necessárias, garantido o direito de ressarcimento dos custos despendidos.

Uma inovação introduzida pela lei estadual refere-se à obrigatoriedade do órgão ambiental competente de "determinar ao responsável pela área contaminada que proceda no prazo de até cinco dias à averbação da informação da contaminação da área na respectiva matrícula imobiliária", a partir do momento em que ela esteja classificada como Área Contaminada. O mesmo dispositivo prevê que não havendo a possibilidade de identificar ou localizar o responsável pela área, ou então na sua omissão, o órgão ambiental competente terá a obrigação de oficiar ao Cartório de Registro de Imóveis para que seja divulgada a contaminação do imóvel, juntamente com as demais informações referentes à sua matrícula.

Na realidade, uma decisão anterior a esta lei, da Corregedoria da Geral da Justiça de São Paulo, publicada no Diário Oficial do Estado em 12/06/2006, já previa a publicidade registrária da contaminação. 
A Lei $n^{0}$ 13.577/09 também cria o Fundo Estadual para Prevenção e Remediação de Áreas Contaminadas (FEPRAC), fundo de investimento vinculado à Secretaria do Meio Ambiente, que deverá ser utilizado na proteção do solo e nas ações de identificação e remediação de áreas contaminadas.

O Decreto $n^{\circ} 54.544$, de 8 de julho de 2009, regulamenta o inciso XIII do artigo $4^{\circ}$ e o inciso VIII do artigo 31 da Lei $n^{\circ} 13.577 / 09$, que dizem respeito à compensação ambiental a ser recolhida pelo empreendedor ao FEPRAC, por ocasião do "licenciamento ambiental de empreendimento cuja atividade seja potencialmente passível de gerar área contaminada".

Deve-se salientar que a Relação de Áreas Contaminadas, divulgada pela CETESB e atualizada até dezembro de 2011, ainda registra uma expressiva maioria de instalações destinadas ao armazenamento e abastecimento de combustíveis, em razão da edição da Resolução CONAMA no 273/2003, que condicionou a "localização, construção, instalação, modificação, ampliação e operação de postos revendedores, postos de abastecimento, instalações de sistemas retalhistas e postos flutuantes de combustíveis" ao prévio licenciamento do órgão ambiental competente, tarefa que o nível estadual tomou para si por meio da Resolução SMA 05/2001. O gráfico abaixo demonstra a distribuição das áreas contaminadas no estado de São Paulo, em dezembro de 2011, conforme o tipo de atividade exercida no imóvel (Figura 8).



Figura 8: Distribuição das áreas contaminadas por tipo de atividade no estado de São Paulo Fonte: CETESB

Cabe mencionar, ainda, o Decreto Estadual $n^{\circ} 47.400$, de 04 de dezembro de 2002, alterado pelo Decreto Estadual no 55.149, de 10 de dezembro de 2009, que regulamenta dispositivos da Lei Estadual $n^{\circ}$ 9.509/97, relativos ao licenciamento 
ambiental, e institui procedimento obrigatório de comunicação ao órgão competente do Sistema Estadual de Administração da Qualidade Ambiental acerca da suspensão ou encerramento de atividades de empreendimentos sujeitos ao referido licenciamento, com a apresentação de um Plano de Desativação que contemple a situação ambiental existente e as medidas necessárias para a restauração e recuperação da qualidade ambiental do local. Esta mesma disposição reaparece, mais recentemente, na Lei $n^{\circ} 13.577 / 09$, citada acima.

O Município de São Paulo trata a questão das áreas contaminadas de forma genérica, por meio da Lei $n^{0} 13.430$, de 13 de setembro de 2002, que instituiu o Plano Diretor Estratégico, e da Lei no 13.885, de 25 de agosto de 2004, que além de estabelecer normas complementares ao Plano Diretor, instituiu os Planos Regionais Estratégicos das Subprefeituras e dispôs sobre parcelamento do solo e normas referentes ao Uso e Ocupação do Solo no Município.

O Plano Diretor Estratégico apenas relaciona, entre os objetivos relativos à política de resíduos sólidos, a recuperação de áreas públicas contaminadas ou degradadas, enquanto que a Lei no 13.885/04 dispõe sobre o tema, em seu artigo 201, da seguinte forma:

"Art. 201. A aprovação de projeto de parcelamento do solo, edificação, mudança de uso ou instalação de equipamentos que necessitem de autorização especial, em terrenos públicos ou privados considerados contaminados ou suspeitos de contaminação por material nocivo ao meio ambiente e à saúde pública, ficará condicionada à apresentação pelo empreendedor, de laudo técnico conclusivo de avaliação de risco, assinado por profissional habilitado, de investigação do terreno para o uso existente ou pretendido, o qual será submetido à apreciação e deliberação da Secretaria do Verde e Meio Ambiente - SVMA, através do Departamento de Controle da Qualidade Ambiental - DECONT, respeitada a legislação pertinente em vigor.

$\S 1^{\circ}$ - Classificada a área como contaminada, será solicitado ao empreendedor o projeto de recuperação ambiental nos termos de procedimento a ser definido pela SVMA.

$\S 2^{\circ}$ - Para fins de aplicação do disposto no "caput", considerar-se-ão suspeitos de contaminação os imóveis que tenham, a qualquer tempo, abrigado qualquer das seguintes atividades:

I. indústria química;

II. indústria petro-química;

III. indústria metalúrgica;

IV. indústria farmacêutica;

V. montadoras;

VI. indústria têxtil/ tinturaria;

VII. depósitos de resíduos;

VIII. depósito de materiais radioativos;

IX. depósito de materiais provenientes de indústria química;

X. aterro sanitário;

XI. cemitério;

XII. mineração;

XIII. hospital;

XIV. posto de abastecimento de combustível. 
$\S 3^{\circ}$ - Poderão ser incluídas na lista de atividades mencionadas no parágrafo anterior, por ato do Executivo, atividades comprovadamente contaminadoras do solo e subsolo por material nocivo ao meio ambiente e à saúde pública".

O artigo 201, acima, apresenta equívocos de ordem conceitual, como a exigência da apresentação da avaliação de risco para os terrenos considerados contaminados ou suspeitos de contaminação. As áreas suspeitas de contaminação são aquelas que, durante o processo de investigação, indicaram a presença de indícios de que o local pode conter substâncias em quantidades ou concentrações passíveis de causar danos à saúde humana, ao meio ambiente ou outro bem a proteger. Entretanto, somente após a realização da investigação confirmatória, é que se pode afirmar se a área está contaminada ou não. A avaliação de risco é um procedimento técnico exigido para áreas comprovadamente contaminadas, no qual se procede à identificação, avaliação e quantificação dos riscos em função da existência de material poluente, o que significa dizer que não cabe exigi-la no caso de área suspeita de contaminação.

Além disso, o artigo 201 não faz menção às áreas com potencial de contaminação, definidas pela Lei Estadual n 13.577/09, anteriormente citada, como aquelas "onde são ou foram desenvolvidas atividades que, por suas características, possam acumular quantidades ou concentrações de matéria em condições que a tornem contaminada". Do ponto de vista do Uso e Ocupação do Solo, especialmente no processo de aprovação de novas edificações, de reformas e de mudança de uso, elas são fundamentais para o adequado gerenciamento das áreas contaminadas.

Outro problema identificado no artigo 201 refere-se ao inciso VIII, do $\S 2^{\circ}$, que considera suspeitos de contaminação os imóveis que tenham abrigado depósito de materiais radioativos. Embora seja possível referir-se à contaminação por radiação, a rigor ela não se insere no âmbito do que se convencionou denominar de "Áreas Contaminadas", em vista do seu caráter específico. Além do mais, no campo da competência legal, o assunto é tratado exclusivamente pelo nível federal.

A legislação municipal específica sobre o assunto inclui os seguintes documentos legais:

- Decreto $n^{\circ}$ 42.319, de 21 de agosto de 2002, que dispõe sobre diretrizes e procedimentos relativos ao gerenciamento de áreas contaminadas no Município de São Paulo; 
- Lei $n^{\circ}$ 13.564, de 24 de abril de 2003, que dispõe sobre a aprovação de parcelamento de solo, edificação ou instalação de equipamentos em terrenos contaminados ou suspeitos de contaminação por materiais nocivos ao meio ambiente e à saúde pública, e dá outras providências;

- Lei $n^{\circ}$ 15.098, de 05 de janeiro de 2010, que obriga o Poder Executivo Municipal a publicar na Imprensa Oficial ou disponibilizar no site oficial da Prefeitura Relatório das Áreas Contaminadas do Município de São Paulo;

- Decreto $n^{0} 51.436$, de 26 de abril de 2010, que regulamenta a Lei $n^{0} 15.098$, de 5 de janeiro de 2010.

Quanto ao Relatório das Áreas Contaminadas do Município de São Paulo previsto pela Lei no 15.098/10 e seu respectivo decreto regulamentador, a Prefeitura passou a divulgá-lo na página da internet da Secretaria do Verde e do Meio Ambiente, a partir do início de 2011. Entretanto, a existência de alguns registros de terrenos já edificados e em plena atividade causa dúvidas com relação à sua real situação, como a construção localizada na avenida Paulista, 1257, esquina com a rua Pamplona, 670, classificada como "contaminada sob investigação", onde até alguns anos atrás havia um posto de combustíveis, ou o caso de um grande condomínio de edifícios residenciais, construído na rua Sapucaia, Subprefeitura da Mooca, enquadrada como "em processo de monitoramento para reabilitação". Nestes casos, em virtude da ausência de informações no cadastro, não é possível saber se os locais já foram objeto de remediação, a exemplo do que ocorre na Relação de Áreas Contaminadas da CETESB, que contempla a categoria de Área Remediada para Uso Declarado.

Ao incluir o Cadastro de Áreas Contaminadas como um dos instrumentos destinados à implantação do sistema de proteção da qualidade do solo e para o gerenciamento de áreas contaminadas, a Lei Estadual no 13.577/09 estabelece que ele será "composto por informações registradas nos órgãos públicos estaduais e municipais e será publicado no Diário Oficial do Estado e na página da internet da Secretaria do Meio Ambiente". Entretanto, constata-se, na prática, que grande parte dos registros constantes do relatório municipal ainda não faz parte da relação do órgão estadual. 


\section{Capítulo 3}

\section{A experiência internacional no gerenciamento de áreas contaminadas}

\subsection{As experiências internacionais no reúso de brownfields}

A recuperação e o reúso de áreas contaminadas, executados dentro de padrões que garantam a segurança dos usuários e dos ecossistemas, podem representar uma grande oportunidade de promover a reabilitação de antigas áreas industriais que poderiam permanecer subutilizadas, ou mesmo abandonadas, contribuindo para a deterioração das estruturas físicas e sociais existentes.

Países pioneiros na identificação desses problemas vêm trabalhando no aperfeiçoamento de um arcabouço técnico e legal que possibilite não só o retorno dos terrenos afetados ao mercado e às atividades privadas e públicas, mas também a participação de todos os setores interessados da sociedade, de modo a alcançar a melhoria das condições ambientais.

Nos Estados Unidos, o impulso para a transformação dessas áreas ocorreu por meio dos programas para a recuperação de brownfields, promovidos pela agência federal de proteção ambiental United States Environmental Protection Agency (USEPA). Brownfields, na definição da própria agência, são os bens imóveis, a expansão, a reabilitação ou reúso que podem ser dificultados pela presença real ou potencial de uma substância perigosa, poluente ou contaminante.

A aprovação do Comprehensive Environmental Response Compensation and Liability Act (CERCLA), em 1980, permitiu o estabelecimento de procedimentos referentes ao gerenciamento dos brownfields e a criação de um fundo, o Superfund, destinado à limpeza de áreas sem controle ou abandonadas que contenham resíduos perigosos, assim como de acidentes, derramamentos e outras formas de liberação de poluentes e contaminantes no meio ambiente (USEPA), sendo dotado basicamente de recursos provenientes de tributo incidente sobre indústrias químicas e petrolíferas. A definição para utilização do Superfund obedece a uma ordem de prioridade de áreas com maior risco, de acordo com a National Priorities List (NPL), que se baseia na aplicação de uma metodologia para a pontuação e a classificação dos locais, denominada Hazard Ranking System (HRS). 
O CERCLA conferiu autoridade à USEPA para identificar as partes responsáveis pelos danos e obter a sua cooperação no processo de remediação, mediante acordo entre as partes ou acordo judicial, além de permitir a recuperação de "'áreas órfãs", ou seja, aquelas nas quais não é possível identificar ou localizar os potenciais responsáveis, ou quando estes não agem no sentido de promover a remediação. Neste último caso, os custos são posteriormente cobrados dos indivíduos e companhias considerados financeiramente viáveis.

Hollander, Kirkwood \& Gold (2010) afirmam que o principal motivo para a existência de muitos dos brownfields está relacionado à preocupação dos proprietários sobre os riscos de responsabilidade legal aos quais estão expostos, no caso de possuírem um terreno contaminado. Sob este aspecto, o CERCLA, em sua versão original, era tido como bastante severo a qualquer um que tivesse tido direitos de propriedade sobre uma área contaminada, ou tivesse mantido uma hipoteca ou direito de uso sobre uma área com tal característica, independentemente de terem sido os causadores do problema. Os autores referemse à política draconiana imposta pelo CERCLA, que só teria começado a se modificar a partir da sua revisão de 2002, com o intuito de limitar a responsabilidade das partes.

Seis anos após a sua implementação, a lei do CERCLA já recebia uma emenda em 1986, por meio do Superfund Amendments and Reauthorization Act (SARA), dando continuidade ao programa conduzido pela USEPA, com a introdução de aperfeiçoamentos, esclarecimentos, exigências técnicas e ampliação das atribuições das autoridades competentes, além da exigência de uma revisão do Hazard Ranking System pela agência ambiental federal, de modo a assegurar que este sistema pudesse avaliar de forma precisa o grau de risco em relação à saúde humana e aos ecossistemas, causado pela presença de resíduos perigosos não controlados.

A partir do Resource Conservation Recovery Act (RCRA), de 1976, a USEPA passou a ser o órgão federal responsável pelo controle de resíduos perigosos, desde a sua geração, passando pelo transporte, tratamento, armazenamento, até a sua disposição final. A revisão do RCRA, de 1986, possibilitou a atuação da agência também sobre a contaminação resultante de petróleo armazenado em tanques subterrâneos e outras substâncias perigosas. 
De maneira similar ao programa de brownfields do CERCLA, que se destina à recuperação de sítios abandonados, o RCRA mantém o foco sobre instalações ativas, atuando, por exemplo, em ações corretivas que permitem o reúso seguro destas áreas.

O programa de brownfields do RCRA ainda concede subvenções para caracterização e avaliação, subsídios e empréstimos para remediação, além de subsídios para outras atividades como treinamento, pesquisa e assistência técnica, os quais estão disponíveis para governos locais, órgãos da administração indireta, conselhos regionais, agências de reabilitação, organizações sem fins lucrativos, entidades criadas por legislação estadual, tribos indígenas, entre outros.

Em 2001, mudanças significativas foram implementadas pelo Small Business Liability Relief and Brownfields Revitalization Act, conhecido como "the Brownfields Law", que alterou a lei do CERCLA, provendo fundos para aplicação na avaliação e remediação de áreas contaminadas e estabelecendo maior flexibilidade no que se diz respeito à responsabilidade legal e financeira em determinadas situações, por meio da isenção dos custos das medidas reparadoras para os pequenos geradores de brownfields, as organizações sem fins lucrativos e os geradores economicamente falidos. Outra importante medida definida pelo ato refere-se à instituição da figura do "proprietário inocente", que isenta da responsabilidade legal e financeira, total ou parcial, os compradores de terrenos que tenham realizado todas as investigações obrigatórias e que posteriormente venham a descobrir a existência de passivos ambientais.

Embora a USEPA se sobressaia como o principal agente, quando se trata da investigação ambiental e da remediação da contaminação, outras agências federais, entre as quais o Departamento de Habitação e Desenvolvimento Urbano (HUD), a Administração de Desenvolvimento Econômico (EDA), o Departamento de Energia (DOE) e a Agência Oceânica e Atmosférica Nacional (NOAA), também atuam no apoio à reabilitação de brownfields, após a conclusão das investigações ambientais preliminares, que se materializam sob a forma de subvenções e assistência técnica aos governos locais.

Os programas federais, segundo Hollander, Kirkwood \& Gold (2010), representam a mais importante fonte de recursos financeiros e de suporte necessários ao reúso de brownfields e, ao mesmo tempo, um ponto de entrada, 
conectando companhias de desenvolvimento de brownfields com uma ampla rede de programas estaduais, locais, legais e de seguro disponíveis.

A partir de meados dos anos 1990, diversos estados norte-americanos passaram a desenvolver suas próprias versões de programas de brownfields, com o apoio da USEPA. Nos estados com políticas mais efetivas, os profissionais vinculados ao poder público exercem funções semelhantes à de gerentes de projetos nas agências regulatórias, auxiliando na viabilização da recuperação dessas áreas. Hollander, Kirkwood \& Gold (2010) mencionam como inovação no nível estadual o emprego de consultores ambientais no lugar de servidores, para atuarem junto a reguladores federais e estaduais, agências locais, planejadores e projetistas, na realização de estudos e avaliações das condições ambientais de terrenos, assistência e orientação aos proprietários, assim como no adequado planejamento da remediação, do reúso e das estratégias de monitoramento.

Considerando que é no nível local que a viabilidade dos projetos é realmente testada na prática, os referidos autores ressaltam o papel essencial das políticas locais e da capacidade das equipes de projeto de transitar pela estrutura de poder de uma vizinhança. Além de exercerem um forte controle sobre o uso final e a recuperação de brownfields, os governos locais podem oferecer entre outras vantagens, maior flexibilidade na taxação dos projetos e priorização de recursos federais e estaduais. Uma ferramenta que tem sido utilizada pelas cidades neste campo é o Tax Increment Financing (TIF), o qual permite o empréstimo de recursos financeiros para o pagamento de custos referentes a projetos ou à própria remediação. Trata-se, basicamente, de um instrumento legal que permite às autoridades locais arrecadar um adicional de impostos sobre propriedades localizadas em distritos da cidade designados como TIF, nos quais a prefeitura pretende promover o redesenvolvimento urbano ou o desenvolvimento econômico, mediante a elaboração de um plano correspondente. O adicional em questão corresponde à parcela relativa à valorização dos imóveis em relação ao seu valor fixado anteriormente à criação do distrito TIF, podendo ser utilizado para a quitação de dívidas contraídas para o financiamento de obras de infraestrutura ou melhoramentos. As áreas destinadas à revitalização urbana geralmente estão localizadas em regiões mais antigas da cidade ou em áreas de brownfields. 
Apesar das ações governamentais que visam promover o incentivo à remediação e ao reúso de terrenos contaminados, mesmo nos Estados Unidos a questão da responsabilidade ainda é um aspecto bastante preocupante aos empreendedores. Um importante instrumento que procura preservar proprietários anteriores de um terreno da responsabilidade continuada decorrente da existência de contaminação, mediante a restrição do seu uso futuro, consiste numa espécie de contrato denominado Activity Use Limitation (AUL), que passa a integrar a escritura de transferência do imóvel, após negociação entre o proprietário e a agência reguladora estadual ou federal. Medida com certa semelhança foi adotada recentemente em São Paulo, pela Lei Estadual no 13.577, de 8 de julho de 2009, que impõe ao órgão ambiental competente a obrigatoriedade de "determinar ao responsável pela área contaminada que proceda no prazo de até cinco dias à averbação da informação da contaminação da área na respectiva matrícula imobiliária", assim que ela esteja identificada como Área Contaminada. A diferença fundamental em relação ao Activity Use Limitation é o fato de que, no caso norteamericano, ficam registradas as restrições de usos futuros, podendo elas estar circunscritas a determinadas porções do terreno.

Há alguns anos o mercado de seguros também vem se mobilizando para oferecer produtos que têm como finalidade proteger incorporadores imobiliários da responsabilidade relacionada à remediação e aos custos adicionais decorrentes de problemas ambientais não previstos.

As apólices de Responsabilidade Ambiental (Pollution Liability policies) são os instrumentos mais antigos e utilizados e cobrem parcialmente demandas contra custos de remediação, danos físicos e prejuízos causados pela disseminação das condições de poluição ou pela migração de poluentes para fora dos limites da propriedade segurada, além dos custos relativos à defesa no âmbito jurídico e do saneamento da situação de contaminação descobertas pelo segurado. O período de validade dessas apólices pode variar de um a dez anos, com possibilidade de extensão destes prazos.

As apólices de Cost Cap (Cost Cap policies) visam proteger o segurado de eventuais custos de recuperação de uma área, que excedam o previsto pelo plano de remediação, oferecendo assim uma cobertura complementar àquelas colocadas à disposição pelas apólices de Responsabilidade Ambiental. O trabalho da Northern 
Kentucky University (2005), elaborado para a USEPA, destaca a exigência de um maior grau de expertise nos contratos das apólices de Cost Cap, especialmente no aspecto relativo à especificação do plano de remediação ou do escopo de trabalho anexado às apólices, que deve ser realizada de forma bastante criteriosa para evitar, por exemplo, riscos adicionais provocados pela necessidade de ações de remediação não previstas, necessárias para se atingir os padrões exigidos pela legislação.

As apólices pré-financiadas (Pre-funded policies) trabalham com o pagamento antecipado de despesas em brownfields com planos de remediação, incorporando elementos presentes nas apólices de Responsabilidade Ambiental e de Cost Cap. Neste instrumento, o prêmio é pago pelo segurado, e o valor líquido dos custos esperados para a remediação é creditado a uma conta mantida pelo segurador e utilizado à medida que os trabalhos são executados. Havendo saldo remanescente ao final da remediação, o segurado pode resgatá-lo, com os respectivos juros; caso contrário, se os custos de remediação forem superiores aos estimados, a apólice arca com os custos adicionais até um determinado valor.

Além dos produtos mencionados, o mercado de seguros norte-americano dispõe de outros produtos, cada qual adequado a uma situação e a valores de remediação específicos. Apesar dos custos elevados envolvidos, a contratação de um seguro, nestes casos, eleva o nível de garantia da realização das ações de remediação e preserva o empreendedor de eventuais problemas financeiros.

Não obstante a experiência acumulada pela USEPA, alguns especialistas americanos têm realizado críticas a aspectos do atual modelo desenvolvido pelo programa Superfund, como a ênfase à priorização da rapidez na limpeza de sítios contaminados, o que nem sempre se efetiva na prática, ou ainda a dificuldade em lidar com as incertezas encontradas nesse processo. Canon (2010) acrescenta, também, o foco do programa na proteção à saúde pública, deixando de considerar ou marginalizando outras dimensões significativas do problema, tais como a função ecológica, o desenvolvimento econômico e a compatibilidade com as aspirações da comunidade local. Destaca, também, o papel dominante do nível federal na tomada de decisões nas áreas integrantes do programa, enquanto a determinação sobre o uso dos terrenos cabe aos proprietários e às autoridades locais. 
Uma das alternativas atualmente propostas por especialistas para a remodelação do programa Superfund é o do gerenciamento adaptativo, que tem origem no gerenciamento de ecossistemas em locais nos quais se encontram altos níveis de incerteza nas dinâmicas dos sistemas naturais e nas suas respostas às intervenções humanas, procurando verificar se a capacidade de adaptação dos sistemas ecológico e social consegue manter o mesmo ritmo. Esta abordagem visa obter, fundamentalmente, uma maior flexibilidade na tomada de decisões e nos ajustes de estratégias de projeto, com base na avaliação dos efeitos resultantes de resoluções anteriores e de novas informações provenientes de outras fontes, o que Ihe atribui um caráter de continuidade, ao trabalhar em diferentes escalas de espaço e tempo e nos diversos níveis institucionais. Contudo, esta ainda é uma discussão em andamento, sobre a qual pairam controvérsias, mas que de qualquer forma estimulam o debate a respeito da necessidade de se tratar a questão de uma forma não linear, não previsível e com perspectivas de prazo mais alongadas.

Enquanto as áreas tratadas no âmbito do programa Superfund restringem-se àquelas consideradas prioritárias pelo governo federal, incluídas na National Priorities List (NPL), no nível estadual, houve uma proliferação de programas com ênfase na utilização de parcerias público-privadas e ações voluntárias de brownfileds, que Lowhan (2012) define como áreas geralmente não contaminadas o suficiente para serem inseridas em programas direcionados, como o Superfund, mas que são evitadas pelos empreendedores imobiliários em razão do receio da contaminação e da responsabilização pelos custos de remediação.

Hula (2012) relata que, de acordo com o Environmental Law Institute, quarenta e quatro estados dispunham de programas para o tratamento voluntário de brownfields até o ano de 1998, sendo que a maioria deles oferecia um conjunto de mecanismos para a indução da participação de parceiros privados, além de modificações na tradicional forma de responsabilização prevista pela legislação federal, de modo a proporcionar algum tipo de proteção aos empreendedores ou proprietários não causadores da contaminação. Revela, ainda, que muitos estados também adotaram o uso de padrões mais flexíveis para o controle do nível de remediação, em muitos casos vinculando-os ao tipo de uso final da propriedade e permitindo o uso de barreiras físicas e controles institucionais para reduzir o grau de exposição humana aos contaminantes. Em situações extremas, alguns estados 
simplesmente baixaram os padrões aos níveis requeridos pelos empreendedores privados.

Knapp \& Hollander (2012), por sua vez, fazem menção aos Community Benefit Agreements (CBAs) como instrumento legal instituído na forma de um contrato entre empreendedores privados e organizações comunitárias pelo qual os primeiros se comprometem a executar um conjunto específico de benefícios públicos, determinado pela comunidade, em troca do seu apoio e aprovação ao desenvolvimento de um determinado projeto, inclusive nos aspectos regulatórios e na obtenção de subsídios públicos. Apesar da expectativa da criação de empregos e de receitas para a revitalização da comunidade, os autores reconhecem que não há garantias de que isso realmente se efetive ao longo do tempo e nem de que deslocamentos causados pela gentrificação, como consequência da revitalização urbana, deixem de ocorrer, o que implicaria a necessidade da criação de mecanismos e programas para que os residentes locais pudessem usufruir dos benefícios advindos dos projetos de desenvolvimento implantados.

Quando se trata da revitalização de brownfields, Knapp \& Hollander (2012) apontam três discursos proeminentes, o primeiro deles relacionado ao racionalismo administrativo, que abarca os aspectos da política e da regulação do processo de renovação urbana, o segundo vinculado ao racionalismo econômico, particularmente em termos de revitalização econômica e desenvolvimento imobiliário, e o último relativo à justiça ambiental, com maior enfoque no legado da contaminação do solo e da desindustrialização e nos impactos ambiental, social e econômico sobre as comunidades de baixa renda, desprovidas de poder político. Identificam, no entanto, uma crescente ênfase na literatura sobre brownfields, durante as últimas décadas, para a interconexão entre os discursos administrativo e econômico como política a ser adotada na revitalização de terrenos contaminados e subutilizados, de forma lucrativa, e a indicação das parcerias público-privadas como o modelo mais promissor. Colocam, por fim, como debate fundamental, não só com relação à revitalização de brownfields, mas da própria comunidade, o questionamento com relação à real possibilidade de se atingir a equidade social ao se orientar programas e projetos quase que exclusivamente em direção ao crescimento econômico e ao desenvolvimento privado. 
Embora reconhecendo que a revitalização de brownfields se apresenta como uma oportunidade para a recomposição física de comunidades que sofreram os efeitos danosos do processo de desindustrialização, assim como para a união de esforços de moradores e outros atores locais, com a finalidade de exercer influência política sobre a definição dos usos finais das áreas que serão objeto de intervenção, Knapp \& Hollander (2012) constatam a existência de uma relutância das autoridades municipais para exigir que os projetos nessas áreas objetivem o desenvolvimento equitativo da comunidade. Alertam, ainda, para a paralisação de diversos projetos de planejamento baseados na comunidade, em função da atual recessão econômica e da crescente tendência das autoridades locais em dar prioridade a projetos privados de grande escala, como forma de impulsionar a arrecadação de tributos e suprir a falta de recursos financeiros.

$\mathrm{Na}$ Europa, assim como nos Estados Unidos e outras regiões do mundo, a maior parte dos brownfields teve origem na atividade industrial. As implicações das transformações de um mercado globalizado sobre as estruturas produtivas locais podem se traduzir na perda da função industrial, produzindo impactos negativos na situação social e econômica das áreas afetadas. Como consequência, grande parte das construções e instalações, assim como dos terrenos que compunham o suporte físico necessário ao funcionamento de tal atividade resultaram em áreas abandonadas, que em muitos casos estão inseridas no tecido urbano e contribuem significativamente para a degradação da qualidade de vida nas cidades.

Em diversos países europeus verifica-se o fenômeno da ocupação dos greenfields, isto é, de áreas situadas em cidades ou zonas rurais ainda não utilizadas para fins urbanos. Neste contexto, a reintegração dos brownfields nas estruturas espaciais existentes apresenta-se como uma das condições essenciais na busca de uma sustentabilidade urbana, ainda que se reconheça tratar-se de uma tarefa extremamente complexa, tendo em vista as questões de caráter econômico, ecológico e social, bem como os aspectos técnicos e legais e os interesses dos diversos atores envolvidos no problema.

A Diretiva 2004/35/CE do Parlamento Europeu e do Conselho da União Europeia, de 21 de abril de 2004, dispõe sobre a responsabilidade ambiental em termos de prevenção e reparação de danos ambientais. O documento parte de algumas premissas, entre as quais a da aplicação do princípio do poluidor-pagador 
na prevenção e reparação de danos ambientais, segundo o qual ocorre a "responsabilização financeira do operador cuja atividade tenha causado danos ambientais ou a ameaça iminente de tais danos". Considera-se, no entanto, que a eficácia do mecanismo da responsabilização depende da possibilidade de haver um ou mais poluidores identificáveis, do dano ser concreto e quantificável e do estabelecimento do nexo de causalidade. Ainda, no que concerne à avaliação dos danos ao solo, a diretiva julga "conveniente a utilização de processos de avaliação de riscos para determinar em que medida poderá a saúde humana vir a ser negativamente afetada".

Neste documento, define-se como dano "a alteração adversa mensurável de um recurso natural ou a deterioração mensurável do serviço de um recurso natural, quer ocorra direta ou indiretamente". Considera-se o dano causado especificamente ao solo como qualquer contaminação "que crie um risco significativo de a saúde humana ser afetada adversamente devido à introdução, direta ou indireta, no solo ou na sua superfície, de substâncias, preparações, organismos ou microrganismos".

Admite-se, ainda, a possibilidade dos Estados-membros adotarem condições mais rigorosas sobre a prevenção e a reparação dos danos ambientais, ou mesmo de seguir procedimentos próprios nos casos de "eventual dupla cobrança de custos em resultado de ações concorrentes por parte da autoridade competente".

Com o objetivo de cobrir responsabilidades decorrentes das disposições estabelecidas pela diretiva, determina-se, também, que os Estados-membros tomem medidas para incentivar os operadores econômicos e financeiros a desenvolver instrumentos e mercados de garantias financeiras.

A comunicação 231 da Comissão das Comunidades Europeias ao Conselho, ao Parlamento Europeu, ao Comitê Econômico e Social Europeu e ao Comitê das Regiões, de 22 de setembro de 2006, relativo à Temática Estratégica para a Proteção do Solo, estimava o número de sítios potencialmente contaminados na União Europeia em cerca de três milhões e quinhentos mil.

Na Alemanha, de acordo com Grimski (2003), a constituição federal determina que o gerenciamento do solo é responsabilidade das autoridades locais, e que as iniciativas práticas devem ocorrer de forma inserida em planos regionais de uso e ocupação do solo ou em estratégias de urbanização. Ressalta, ainda, que diversos 
casos de remediação e reutilização de áreas contaminadas naquele país ocorrem por meio de parcerias público-privadas.

O governo alemão tem colocado a sustentabilidade como um dos preceitos básicos para a elaboração de suas políticas públicas. Sobre este aspecto, Spínola (2011) destaca a lei fundamental de planejamento do território (Raumordnungsgesetz - ROG), reformada em 2009, a qual define entre seus princípios a limitação ao uso de áreas ainda não ocupadas, priorizando o esgotamento daquelas com potencial de reutilização no interior das cidades, inclusive as consideradas degradadas, e revelando uma grande preocupação com a preservação dos greenfields, isto é, das áreas ainda não urbanizadas e não edificadas. Cita, também, os planos de uso do solo e os planos urbanísticos, genericamente denominados de planos diretores de construção, que tratam de aspectos como a proteção do solo e o planejamento urbano, ressaltando o fato de que ambos os planos estabelecem a obrigatoriedade da demarcação de áreas com solo significativamente poluído com substâncias prejudiciais ao meio ambiente.

Marker (2003, p.14), por sua vez, informa que o conceito básico do Raumordnungsgesetz - ROG deve ser obrigatoriamente observado no planejamento territorial estadual, enquanto que, no nível municipal, ele se insere principalmente por meio do Código de Obras (Baugesetzbuch). Entre as exigências contidas na ROG, menciona: "a manutenção das condições de moradia que garante a salubridade e o bem estar da população; a preservação de bairros tradicionais; o uso do solo de maneira econômica e cuidadosa, preservando as áreas verdes rurais e florestais".

Em termos de legislação ambiental, Marker (2003) destaca a importância da Portaria de Proteção do Solo, de 1999, que regulamentou dois pontos da Lei Federal de Proteção do Solo e Remediação de Áreas Contaminadas, de 1998, fixando os valores de investigação e remediação para quatro usos, quais sejam playground, residências, parques, indústria e comércio, e regulamentando o plano de remediação e investigação. No campo administrativo, o Contrato de Remediação estabelece os termos da remediação, o uso futuro da área e as obrigações das partes envolvidas, tornando-se, no seu entendimento, um instrumento central na reabilitação de áreas contaminadas. 
Em se tratando de contaminação do solo e das águas subterrâneas, Hoffmann (2004) ressalta que, de acordo com a legislação alemã, na hipótese da impossibilidade de localização do causador do dano ambiental, o responsável pela área, seja ele o atual proprietário, locatário ou arrendatário, deve ser intimado a realizar a avaliação de risco e a remediação, podendo também ser convocado o exproprietário que tenha transferido a propriedade após $1^{\circ}$ de março de 1999 , com conhecimento da existência da contaminação. Neste caso, o valor máximo da remediação a ser arcado pelo proprietário será equivalente ao valor comercial do terreno. Entretanto, na inviabilidade da responsabilização do causador da contaminação ou do proprietário da área, a legislação determina que o poder público assuma os custos necessários para as medidas de proteção contra o perigo imediato ou para executar a sua reabilitação.

O processo de avaliação de brownfields utilizado pela Alemanha consiste basicamente na progressão da análise das condições do solo e das águas subterrâneas, de forma muito semelhante ao procedimento adotado no Brasil, já que os procedimentos da CETESB para investigação de áreas contaminadas foram definidos a partir de uma cooperação com a agência alemã de cooperação GTZ.

Diferentes fontes de financiamento e programas de incentivo à reabilitação de brownfields e remediação de áreas contaminadas são citadas por Spínola (2011). $\mathrm{Na}$ área federal, o governo alemão disponibiliza programas que, no geral, destinam recursos para a pesquisa e a remediação. Do mesmo modo, os estados também dispõem de programas que oferecem recursos financeiros aos distritos e municípios para serem utilizados na investigação e remediação de áreas contaminadas.

As Sociedades de Desenvolvimento Estadual (Landesentwicklunggesellschaft - LEG) desempenham um papel importante na reabilitação de áreas degradadas, promovendo a implementação de projetos urbanísticos sob o formato de parcerias público-privadas. De acordo com Marker (2003), trata-se de empresas de economia mista dirigidas por funcionários públicos de alto escalão, que têm como objetivo promover o desenvolvimento regional, não só do ponto de vista do planejamento, como da implantação de projetos de habitação e urbanização, atuando conforme as regras de mercado e observando os objetivos e interesses públicos. Spínola (2011) cita a atuação da Sociedade de Desenvolvimento Regional do Estado da Renânia do Norte-Vestfália no desenvolvimento de áreas industriais desativadas, por intermédio 
de um fundo imobiliário, realizando a compra, reabilitação e comercialização de terrenos, muitos deles contaminados desde 1980.

Ainda no âmbito das parcerias público-privadas, Spínola (2011) refere-se à existência de outras formas de cooperação para o tratamento de áreas degradadas, previstas na legislação alemã, destacando dois casos específicos para a remediação de áreas contaminadas. O primeiro deles é a "Sociedade para Remediação de Áreas Contaminadas do Estado da Baviera", criada em 1989, por meio de recursos compartilhados entre iniciativa privada, Estado da Baviera, municípios e comunas, que provê apoio técnico e financeiro na remediação de áreas nas quais os responsáveis não podem mais ser localizados ou não têm capacidade de arcar com os custos para tal finalidade. O outro refere-se à "Associação para Remediação e Tratamento de Áreas Contaminadas", do Estado da Renânia do Norte-Vestfália, constituída em 2002, com a finalidade de executar a investigação e a remediação de áreas contaminadas, além de pesquisas em tecnologias para remediação.

A partir da abordagem de exemplos de revitalização de áreas contaminadas na Alemanha, por meio de parcerias público-privadas, realizada por Kirchholtes (2004), verifica-se que o trabalho de concepção do projeto, de planejamento das ações e estratégias e de busca de parceiros privados para a viabilização das transformações desejadas exige esforços e tempos consideráveis, além de envolver questões de ordem legal, administrativa e financeira, mesmo num contexto no qual se supõe a existência de um arcabouço institucional bastante consolidado. A atuação do poder público ocorre por intermédio da participação de diversos órgãos, principalmente de meio ambiente e de desenvolvimento urbano, e do financiamento parcial das ações, sendo que as atribuições e as responsabilidades de cada uma das partes ficam consubstanciadas em contrato firmado entre o setor público e o investidor privado.

Com base no pressuposto de que os mecanismos de incentivo são essenciais à revitalização de brownfields e à remediação de áreas contaminadas, o governo alemão disponibiliza alguns programas federais que envolvem, de maneira geral, a liberação de recursos financeiros para a realização de pesquisas e a investigação e remediação de áreas contaminadas. Um desses programas visa à remediação de terrenos existentes nos "novos estados" da antiga Alemanha Oriental, nos quais os custos são assumidos na proporção de 40\% pela União e 60\% pelos estados, 
podendo chegar a $75 \%$ e $25 \%$, respectivamente, nos projetos considerados de grande porte, conforme informações do BMU - Bundesministerium für Umwelt, Naturschutz und Reaktorsicherheit (2011 apud SPÍNOLA, 2011, p.195).

\subsection{Os aspectos projetuais}

O reúso e a reabilitação de brownfields constituem uma grande oportunidade para trazer de volta ao cotidiano das cidades áreas abandonadas ou subutilizadas, em razão da perda de suas funções e de seu significado urbano, que ainda carregam o estigma de serem identificadas como territórios dominados pela violência, insegurança e insalubridade.

A constatação da contaminação traz limitações à utilização dos terrenos, porém a definição dos novos usos que lhes serão atribuídos dependerá não só de aspectos mercadológicos, mas principalmente das características da contaminação que afeta a área, com implicações sobre os custos e prazos de remediação e mesmo sobre questões legais.

Considera-se remediação a remoção de poluentes em níveis compatíveis com a proteção à saúde humana, de acordo com o uso que se pretende dar a uma determinada área, ou então a contenção de setores com maior concentração de poluentes, de modo a evitar a sua disseminação. A remediação envolve uma série de fatores e a participação de profissionais de diferentes áreas do conhecimento. De uma forma geral, nos procedimentos adotados para o gerenciamento de áreas contaminadas, os resultados obtidos no processo de investigação e de avaliação de risco subsidiam a elaboração de um plano de remediação, conforme o uso que se pretende dar ao terreno, o que determina o nível de redução da contaminação necessário e as técnicas mais adequadas para cada caso, lembrando que é comum a existência de mais de um tipo de poluente num mesmo local. O plano de remediação e a escolha das técnicas a serem empregadas costumam ser

submetidas à apreciação da autoridade ambiental competente, que deve acompanhar a implementação de todas as ações previstas.

Diversas técnicas podem ser empregadas no processo de remediação, e sua escolha depende de fatores como o tipo de poluente, a capacidade de disseminação no solo e o risco que representa à saúde humana e aos bens a proteger, além do tipo de solo, das condições de circulação das águas subterrâneas e de aspectos 
econômicos, sendo que não raras vezes é necessária a conjugação de mais de um tipo de técnica para se alcançar os objetivos da remediação. As técnicas podem ser divididas em dois grandes grupos: as ex-situ, que consistem na remoção e no tratamento do solo contaminado, o qual pode retornar ao local de origem, e as insitu, que promovem o tratamento do solo sem a necessidade de removê-lo do local. Algumas delas são citadas a seguir, de forma sucinta.

As tecnologias utilizadas nos processos de remediação são constituídas por ações que podem envolver menor ou maior grau de intervenção e, sob este aspecto, Hollander, Kirkwood \& Gold (2010) identificam cinco formas de condução da remediação, a saber:

- limpeza total: consiste na completa escavação do solo de toda a área afetada, com sua posterior remoção a um aterro licenciado, no esgotamento de todos os corpos d'água existentes, incluindo a retirada dos sedimentos, e na extração e remoção ou remediação das águas subterrâneas poluídas;

- limpeza parcial (fora do terreno): implica a remoção do solo contaminado para outro local, onde deve sofrer processo de remediação, podendo o solo retornar ao terreno de origem ou ser destinado a um aterro licenciado ou a outras áreas;

- limpeza parcial (no local): exige tecnologias e a instalação de equipamentos para a execução do processo de remediação na própria área de ocorrência da contaminação;

- capeamento total: trata-se da execução de um sistema de recobrimento do solo para selar a contaminação existente no local, o que inclui obras de terraplenagem para a colocação de uma camada impermeável de argila, posteriormente recoberta por mantas de geotêxtil, e a colocação de outra camada de solo limpo; esta solução exige cuidados para assegurar que a área selada não venha a ser escavada ao longo do tempo, devendo também ser objeto de contínuo monitoramento da qualidade das águas subterrâneas;

- limpeza não intrusiva: emprega tecnologias que mantêm a condição original do terreno e se utiliza de processos naturais que ocorrem no solo e nas águas subterrâneas, por meio da ação do sol, da umidade e do vento, ou então da introdução de micro-organismos no meio afetado e do uso de plantas para decomposição dos poluentes. 
A escolha por uma das opções acima ocorreria, segundo os autores, em função de itens como: os níveis, a extensão e a concentração da contaminação; o tamanho, a localização e as condições físicas da área de trabalho em termos da adesão dos atores envolvidos; a presença de residências próximas da área de trabalho da remediação e o grau de acesso à área para equipamentos e remoção de material contaminado.

Carman (2001) faz referência à tendência emergente ao uso de processos naturais e de tecnologias mais passivas na remediação de áreas contaminadas, basicamente representadas pela biorremediação e fitorremediação, de forma integrada às tecnologias mais convencionais.

A biorremediação consiste na utilização de micro-organismos para a quebra de contaminantes orgânicos em compostos mais simples e inócuos, tanto em processos ex-situ como in-situ, enquanto a fitorremediação faz o emprego de plantas na captação de contaminantes presentes no solo, na água e em sedimentos.

A fitorremediação caracteriza-se como técnica mais adequada à remoção de poluentes em profundidades rasas e apresenta-se como uma opção econômica para áreas extensas com pequenos níveis de contaminação por poluentes orgânicos, metais ou fertilizantes, sem risco iminente à saúde, podendo ser empregada com finalidades estéticas, de forma integrada a projetos paisagísticos. A seleção da espécie vegetal depende basicamente de sua capacidade de efetuar o tratamento do contaminante focado, promovendo a sua extração ou a sua degradação a substâncias atóxicas ou menos tóxicas.

Uma alternativa ao tratamento de águas contaminadas, geralmente associada à fitorremediação, é a construção de wetlands, que buscam reproduzir as condições e as funções básicas de áreas alagadiças naturais, como melhoria da qualidade da água, retenção das águas pluviais, circulação de nutrientes e outros materiais, manutenção da flora e da fauna, além de propiciar situações favoráveis ao aproveitamento paisagístico e ao desenvolvimento de atividades recreativas. Cabe lembrar que as wetlands naturais são áreas de transição entre a água e a terra, que se caracterizam como áreas úmidas permanentemente ou por longos períodos, mantendo o substrato saturado, o que limita a vegetação às espécies adaptadas às condições de pouco oxigênio. 
As limitações ao uso de wetlands construídas estão relacionadas principalmente às dimensões das áreas necessárias à sua implantação e à variação das condições ambientais, assim como da carga e do tipo de poluentes, o que pode afetar a eficiência do sistema.

Na reconfiguração espacial de áreas em processo de remediação, a partir desta perspectiva, torna-se fundamental a existência de um trabalho colaborativo entre profissionais de diferentes áreas do saber, que buscam aliar elementos essencialmente técnicos às questões de projeto e aos aspectos ambientais. Mcneil e Lange (2001) ainda destacam como ponto crítico o conhecimento sobre o histórico de usos da área com a finalidade de avaliar os padrões e o grau de contaminação, uma vez que tais aspectos guardam uma relação direta com a solução de projeto.

Com relação à fitorremediação, Mcneil e Lange (2001) ressaltam a importância de se pesquisar o potencial de novas espécies vegetais na remoção de contaminantes existentes no solo e na água, permitindo assim alargar as possibilidades de projeto e enriquecer a diversidade ecológica, além de avaliar a capacidade de remediação dessa tecnologia em função das concentrações dos contaminantes presentes no local.

O papel do projetista no reúso de um sítio comprovadamente contaminado não se limita às funções convencionais, pois é imprescindível que se compreendam as implicações entre o processo de remediação e a concepção/desenvolvimento do projeto. Hollander, Kirkwood \& Gold (2011) listam como pontos relevantes nesta atividade o estabelecimento do balanço entre as escavações do solo, a remoção do material contaminado e o realinhamento dos níveis do terreno por meio da disposição do material contaminado e das atividades de capeamento. Tendo em vista que, em muitos casos, as obras de remediação podem implicar a movimentação de terra, com a consequente alteração da topografia, há necessidade de se realizar a provisão de solo para eventuais remodelagens do perfil do terreno, bem como de solo adequado para o plantio de vegetação.

O sistema de drenagem é outro aspecto relevante no tratamento de áreas contaminadas, considerando que a prioridade aqui consiste em captar e armazenar as águas pluviais, evitando a sua infiltração no solo, ainda mais nas situações em que há contaminação remanescente, para que os poluentes não atinjam as águas subterrâneas. Este ponto torna-se fundamental em situações nas quais é adotada a 
solução de contenção dos resíduos contaminados, mediante o seu capeamento, o que geralmente ocasiona a formação de grandes superfícies impermeáveis, cobertas por uma camada de solo e vegetação de pequeno porte. A água ali infiltrada poderia ser captada e conduzida por um sistema de drenagem para posterior reúso, ao invés de ser despejado no sistema público de águas pluviais.

Caberia também ao projetista ordenar e compatibilizar as ações relativas à remediação, que podem ocorrer em diferentes etapas, com as atividades do plano geral da obra, tomando a frente não só da coordenação de todas as fases do trabalho, mas também dos diversos consultores envolvidos no projeto, além do contato com a comunidade e as demais partes interessadas.

Países que vêm tratando da questão de maneira sistemática há vários anos já reconheceram o potencial econômico, social e ambiental que a reabilitação de brownfields pode proporcionar, o que os levou a propor uma série de planos, programas e instrumentos de incentivo específicos. Além disso, a experiência desses países demonstra uma grande preocupação em propiciar a participação dos chamados stakeholders, isto é, dos atores envolvidos ou das partes interessadas, tanto nas discussões como nas decisões a respeito do tratamento de brownfields. Sob este ponto de vista, os autores acima citados enfatizam que a atividade do projetista não se limitaria à simples elaboração de material gráfico para demonstrar os benefícios do projeto; compreenderia também a produção de instrumentos capazes de transmitir a complexidade científica e de engenharia envolvida nos processos de remediação, bem como as condições percebidas do brownfield, por meio de explanações sobre as estratégias de remediação, seus efeitos, seus resultados sobre a saúde pública e sobre a sustentabilidade da área, a longo prazo.

No Brasil e em São Paulo, pode-se dizer que o tema ainda é de conhecimento bastante restrito, e as políticas públicas e ações relativas à questão ainda são incipientes. Muitas vezes, quando o problema é trazido à discussão no setor público, acaba sendo encarado como mais um entrave ao andamento dos trabalhos, por exemplo, nos procedimentos concernentes à aprovação de projetos privados e mesmo os de iniciativa do poder público. A procura de terrenos em antigas áreas industriais na cidade de São Paulo pelo setor imobiliário não ocorre, portanto, em função de planos e programas direcionados à recuperação de brownfileds, mas em 
razão de vantagens locacionais e da disponibilidade de infraestrutura e, principalmente, da escassez de terrenos desocupados e com preços mais baixos.

As ações para a requalificação de brownfields na Europa foram disseminadas e ocorreram principalmente em função de organizações e grupos de trabalho criados com a finalidade de desenvolver estudos e propostas sobre o tema, como CLARINET (Contaminated Land Rehabilitation Network for Environmental Technologies), no âmbito da Comissão Europeia, NICOLE (Network for Industrially Contaminated Land in Europe), criada em 1995 com base numa iniciativa da European Chemical Industry Council (CEFIC), CABERNET (Concerted Action for Brownfield and Economic Regeneration Network), ERM (Environmental Resources Management), NBSP (National Brownfields Sites Project) e outros.

O RESCUE (Regeneration of European Sites in Cities and Urban Environments) foi um projeto de pesquisa iniciado em 2002, com prazo de duração de 36 meses, inserido no "50 Programa Estrutural da Comunidade Europeia, no Campo da Pesquisa, Desenvolvimento Tecnológico e Demonstração", com o objetivo de elaborar e testar uma abordagem integrada sistemática contendo novas metodologias, procedimentos e instrumentos para a regeneração de brownfields industriais europeus.

A partir de uma abordagem integrada da questão, o RESCUE (2004) definiu "regeneração sustentável de brownfield" como "o gerenciamento, a reabilitação e o retorno ao uso benéfico de uma área de brownfield de maneira a assegurar a realização e a continuada satisfação das necessidades humanas para as presentes e futuras gerações, de modo ambientalmente sensível, economicamente viável, institucionalmente robusto e socialmente aceitável, dentro do contexto regional particular".

Para avaliar oito estudos de caso de projetos em áreas de brownfields, em quatro países participantes, foi desenvolvida uma metodologia focada nos aspectos social, econômico, ambiental e institucional e na integração entre eles, dos quais derivam um conjunto de indicadores quantitativos e qualitativos.

A metodologia coloca a determinação do uso do solo mais adequado (ou mais sustentável) para uma área de brownfield, em função dos contextos local e regional específicos, como uma das mais importantes decisões a serem tomadas, e 
estabelece alguns parâmetros para subsidiar esta definição. A referência ao contexto, neste caso, permitiria avaliar todos os efeitos que o uso pretendido poderá ter sobre o meio ambiente, a economia e a sociedade de uma forma integrada, visto que nesta metodologia considera-se que a sustentabilidade não pode ser definida em termos genéricos para todos os projetos em brownfields. O quadro a seguir, relaciona os objetivos de sustentabilidade definidos pelo RESCUE, em áreas de brownfields.

1. OBJETIVOS DE SUSTENTABILIDADE RESCUE (EM TERMOS DE PLANEJAMENTO DO USO DO SOLO E DE DESENHO URBANO SUSTENTÁVEIS, EM ÁREAS DE BROWNFIELDS)

\begin{tabular}{|c|l|}
\hline 1 & Promover usos do solo compatíveis com as demandas e necessidades sócio-econômicas regionais \\
\hline 2 & Integrar o reúso de áreas de brownfields na gestão regional do território \\
\hline 3 & Integrar o reúso de áreas de brownfields no desenvolvimento urbano \\
\hline 4 & Alcançar benefícios para a vizinhança e prevenir impactos adversos sobre ela \\
\hline 5 & Gerar e salvaguardar emprego e desenvolvimento econômico \\
\hline 6 & Promover usos do solo que se adaptem ao ambiente natural e construído da área e sua vizinhança \\
\hline 7 & Economizar recursos \\
\hline 8 & Permeabilidade (aumentar a possibilidade do público de transitar por antigas áreas de brownfields) \\
\hline 9 & Prover acessibilidade adequada \\
\hline 10 & Atingir alta qualidade de desenho urbano \\
\hline
\end{tabular}

\section{Quadro 1 - Objetivos de sustentabilidade RESCUE}

Fonte: Regeneration of European Sites in Cities and Urban Environments - RESCUE. Guidance on sustainable land use and urban design on brownfield sites, 2004.

Além da metodologia anteriormente abordada, para orientar a investigação e a reabilitação de brownfields, Sarni (2010) menciona outras iniciativas desenvolvidas com a mesma finalidade, embora reconheça o trabalho do RESCUE como o mais completo e abrangente neste campo. De acordo com este autor, a chave para a recuperação ambiental dessas áreas deveria envolver uma postura proativa e o engajamento de todos os atores envolvidos. 
SARNI refere-se ao "Manual de Brownfields do Colorado", que aborda a questão numa perspectiva local, mas propõe um exercício que seria aplicável de forma universal. Segundo o manual, o papel do governo local seria o de facilitar o processo de reabilitação, provendo:

- "antevisão - reconhecer uma necessidade da comunidade ou econômica;

- formulação de cenários de reúso;

- avaliação de oportunidade de negócio, viabilidade financeira, impactos econômicos e condições ambientais para o reúso de uma propriedade;

- transação - solucionar questões de gerenciamento de risco para facilitar a transferência do título de propriedade (se necessário);

- implementação da reabilitação - conduzir a remediação ambiental, a construção e as etapas de renovação e, enfim, vender a propriedade".

Diferentemente da visão corretiva, Rogers (2001) afirma que o complexo e custoso processo de remediação é a única solução viável quando o dano ambiental já ocorreu, mas que pode ser evitada em muitos casos por meio do desenho e da operação ambientalmente sensíveis das instalações industriais. Considera que a degradação ambiental não deveria ser aceita como um fato dado e reconhece o desafio e a condição única dos projetistas de deter o poder de eliminar os impactos ambientais em todas as fases do projeto, desde o seu início. A este respeito, observa que áreas destinadas a processos produtivos, projetadas de forma inteligente, deveriam ter início a partir dos seguintes aspectos:

- integração da indústria ao sítio, de modo a não colocar em risco os trabalhadores, a comunidade e o meio ambiente;

- conservação de energia e dos recursos, tendo a água como um bem precioso que não deve ser desperdiçado;

- preocupação com a natureza perigosa dos materiais manuseados e a toxicidade dos produtos fabricados, assim como a instalação de tubulações acima do nível do piso, para facilitar a manutenção e a prevenção de vazamentos não percebidos no solo e na água subterrânea;

- plantas que propiciem a luz natural e as vistas, além de criar uma sensação de satisfação no local de trabalho;

- instalações que pressupõem a falibilidade humana e garantam tranquilidade e proteção no curso de seu processo de projeto; 
- instalações nas quais a tecnologia seja mais direcionada à prevenção do que ao controle dos impactos ambientais.

Essa abordagem coincide com a visão proativa no gerenciamento de sítios contaminados, identificada por Sánchez (2001), que distingue cinco formas dominantes no tratamento da questão. A primeira delas corresponderia à atitude de negligência ou omissão perante o problema, na espera que ele se manifeste ou simplesmente permaneça desconhecido, enquanto que nas situações em que a solução é considerada caso a caso, ainda que na forma de ações desarticuladas, ela seria considerada do tipo reativa. A abordagem corretiva, por sua vez, avançaria na direção da adoção de procedimentos visando à identificação, ao diagnóstico e à recuperação, de forma planejada e sistemática, ao passo que a visão preventiva do problema implicaria o fechamento de atividades potencialmente contaminadoras do solo e a tomada de medidas que assegurem a desativação apropriada de empreendimentos. Finalmente, o tratamento proativo da questão estaria fundamentado no conceito de ciclo de vida do empreendimento, que presumiria um tempo finito para a existência da atividade e o planejamento de todas as etapas desse ciclo até o seu encerramento, com o objetivo de evitar a geração de passivos ambientais.

Em diversos empreendimentos industriais ainda há a geração de substâncias tóxicas como subprodutos dos processos produtivos, o que leva à necessidade do planejamento de mecanismos e instalações para o seu tratamento reciclagem ou reutilização, ainda mais num contexto em que os padrões ambientais se tornam cada vez mais restritivos.

Há que se considerar também que, na ocorrência de contaminação do solo e das águas subterrâneas, a eventual necessidade ou exigência de remediação da área implicará gastos que certamente elevarão os custos de produção, reduzindo a margem de competitividade de muitos empreendimentos.

Nessas condições, a abordagem proativa passa a se tornar uma alternativa economicamente interessante e ambientalmente adequada, uma vez que promove a racionalização dos processos produtivos, evitando eventuais gastos desnecessários, e previne o surgimento de danos ao meio ambiente, ainda que reste às corporações multinacionais a opção de instalar suas unidades fabris em países periféricos onde 0 custo da mão de obra é irrisória e as restrições ambientais praticamente inexistem. 
Mesmo assim, há que se considerar que no Brasil, e mais especificamente nas regiões que já dispõem de algum tipo de mecanismo para o gerenciamento de áreas contaminadas, as ações do poder público ainda se pautam predominantemente por uma atitude reativa e as soluções de projeto ainda estão bem distantes do que se pode esperar de uma visão proativa da questão. 


\section{Capítulo 4}

\section{A recuperação de áreas contaminadas, a partir da perspectiva interdisciplinar e interinstitucional, na construção da paisagem pós-industrial na cidade de São Paulo}

\subsection{O processo de transformação das antigas áreas industriais}

A paisagem predominante em antigas áreas industriais da cidade de São Paulo revela o resultado momentâneo de um processo histórico, no qual novos elementos passam a fazer parte de sua composição, enquanto outros, particularmente os ligados à atividade fabril, se tornam obsoletos ao perderem a sua função no contexto das novas articulações que se estabelecem no território, e a consequência mais evidente desta transformação pode ser verificada no grande número de imóveis desativados.

Os chamados brownfields acabam se constituindo, de maneira geral, em regiões da cidade caracterizadas pelo esvaziamento de suas funções anteriores e pela subutilização dos espaços, gerando uma sensação de abandono e insegurança, além de reforçar a percepção de fragmentação do tecido urbano, o que torna a sua recuperação ambiental e a sua reabilitação fatores fundamentais para a criação de condições mais favoráveis ao desenvolvimento das atividades urbanas.

A confirmação da presença de contaminação do solo e/ou das águas subterrâneas representa um elemento agravante no reaproveitamento dos terrenos, tendo em vista o tempo e os custos adicionais necessários à realização da remediação da área, assim como as eventuais implicações legais inerentes a este processo.

$\mathrm{Na}$ cidade de São Paulo, as áreas representativas do período inicial do seu processo de industrialização, entre as quais Brás, Mooca, Lapa, Ipiranga e Vila Leopoldina, e de épocas mais recentes, como Santo Amaro, vêm sofrendo perda gradativa de sua função industrial durante os últimos anos, em diversos casos resultando numa paisagem de imensos galpões fechados ou abandonados, num contexto de migração de empresas para outras regiões do estado ou do país, de mudança no perfil das indústrias na cidade e, ainda, da tendência à terceirização nas atividades produtivas. 
Um processo que se verifica nessas áreas, especialmente na última década, é o da mudança de uso com a implantação de grandiosos condomínios quase sempre de uso residencial, produto da ocupação de terrenos de grandes dimensões, que se caracterizam pela construção de imensas torres em meio a áreas ajardinadas e a uma série de atividades de lazer, encerrados em espaços fechados em si mesmos, de onde só se sai para ir ao trabalho, à escola, ao shopping center ou para executar outras tarefas que só podem ser feitas externamente. Tais empreendimentos invariavelmente mantêm pouca ou nenhuma relação entre si, com o entorno e com o resto da cidade e, em razão das dimensões generosas dos terrenos, acabam dificultando as interconexões entre diferentes áreas de uma mesma região, produzindo zonas em que as pessoas e as relações sociais são praticamente ausentes.

Esta opção do mercado imobiliário pela ocupação de antigos lotes industriais deve-se, sobretudo, à escassez de terrenos desocupados nas regiões mais centrais da cidade e à possibilidade de maior adensamento das zonas de uso que admitem coeficiente de aproveitamento máximo acima de 2,5, o qual pode ser mais elevado em situações específicas, como no caso de operações urbanas; implica, por outro lado, a necessidade de se tomar certas precauções, em virtude da possibilidade da existência de contaminação do solo e das águas subterrâneas, produzida pelas atividades anteriormente exercidas nesses locais. A principal preocupação com relação a essas áreas diz respeito ao risco à saúde humana e aos ecossistemas, quando utilizados de forma inadequada, sem os devidos cuidados.

Este fenômeno da mudança de uso de antigas áreas industriais, com a instalação de novos empreendimentos imobiliários, também pode ser verificado em cidades da Região Metropolitana de São Paulo, como Santo André, São Bernardo do Campo, São Caetano do Sul e Guarulhos, que até algumas décadas atrás desempenhavam importante função industrial. Exemplo disso é o projeto de reocupação de uma grande indústria cerâmica em São Caetano do Sul, numa área de aproximadamente $330.000 \mathrm{~m}^{2}$, onde se pretende instalar um novo bairro com a implantação de edificações residenciais, comerciais e de serviços, além de áreas verdes e de lazer (Fotos 38 e 39). 



Fotos 38 e 39 - Empreendimento em São Caetano do Sul

Fonte: www.sobloco.com.br/espacoceramica

Os terrenos nos quais estão situados os três lançamentos imobiliários abaixo constam da Relação de Áreas Contaminadas, divulgada pela Secretaria do Verde e do Meio Ambiente do Município de São Paulo, em janeiro de 2013 (Fotos 40 a 42 e Figuras 9 a 11). Algumas informações, no entanto, parecem contraditórias, pois nos casos dos empreendimentos da Avenida Eusébio Stevaux e da Rua Borges de Figueiredo, as áreas encontram-se classificadas como "Contaminadas, sob Investigação", ao mesmo tempo em que registram a observação de que se tratam de "Áreas Remediadas" na lista divulgada pela CETESB. Além disso, é possível verificar na foto do primeiro empreendimento que as edificações no local já estão praticamente concluídas, enquanto que na segunda as obras já estão em acelerado ritmo de implantação, fato constatado durante visita ao local, no primeiro semestre de 2012. 


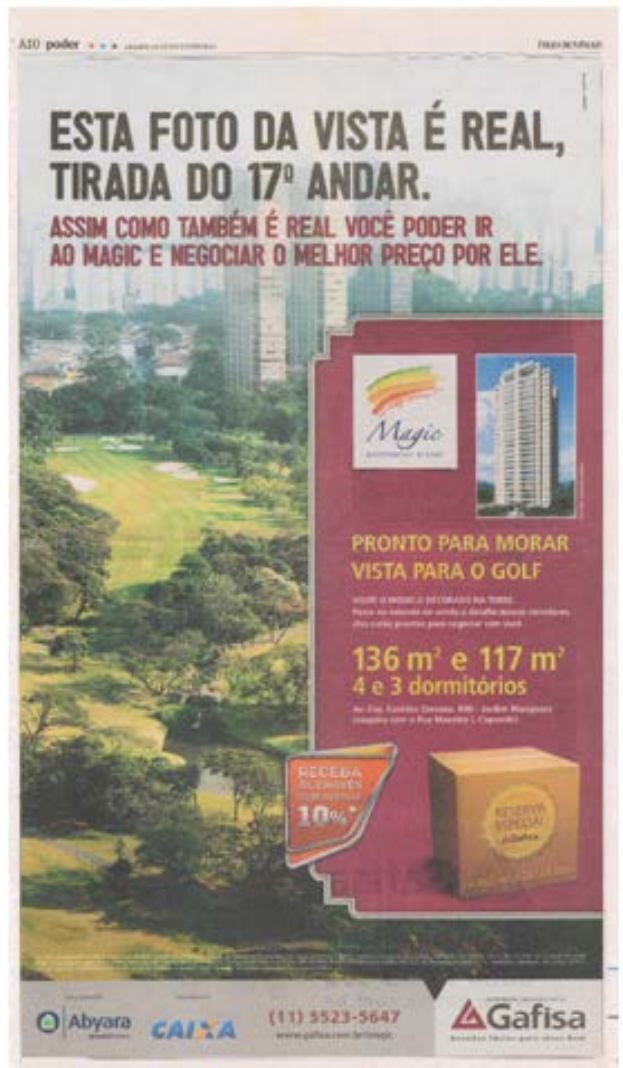

Figura 9 - Anúncio do empreendimento

Fonte: Folha de São Paulo, de 14/08/2010

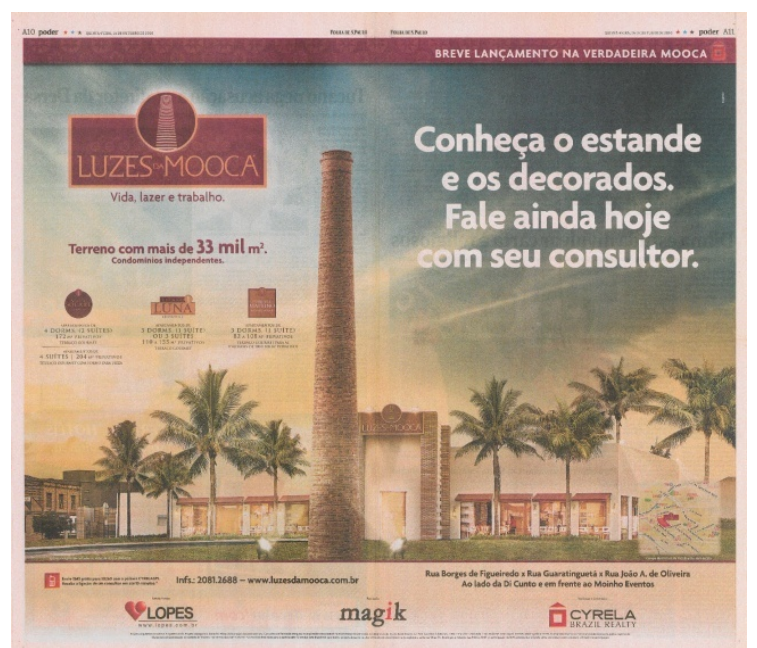

Figura 10 - Anúncio do empreendimento

Fonte: Folha de São Paulo, de 14/10/2010



Foto 40 - Empreendimento imobiliário na avenida Eusébio Stevaux, região de Jurubatuba, Santo Amaro

Foto do autor



Foto 41 - Empreendimento imobiliário na rua Borges de Figueiredo, Mooca

Foto do autor 


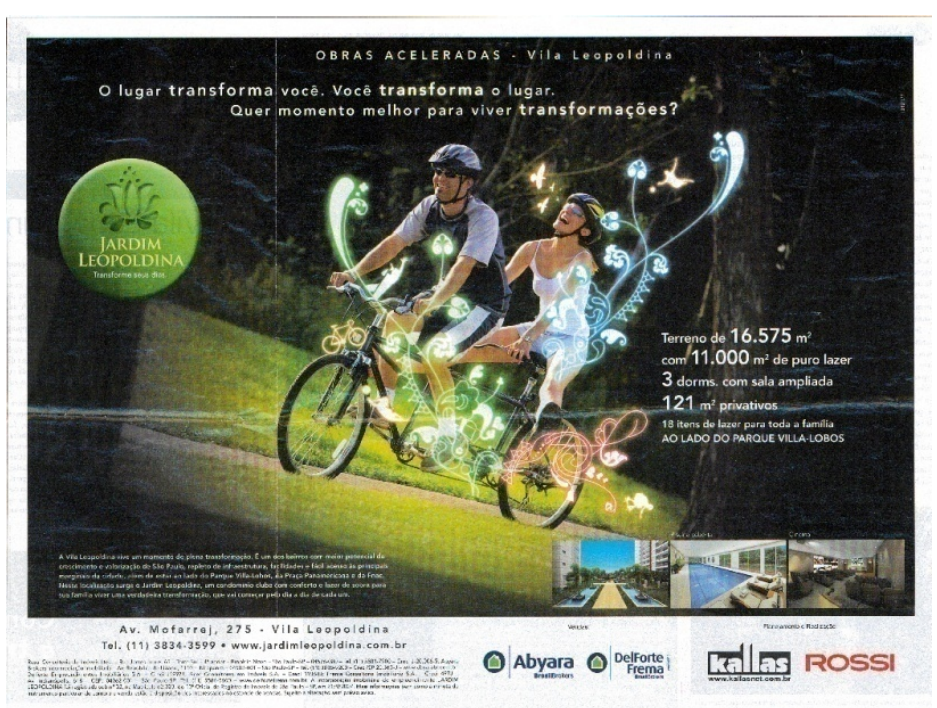

Figura 11 - Panfleto publicitário do empreendimento

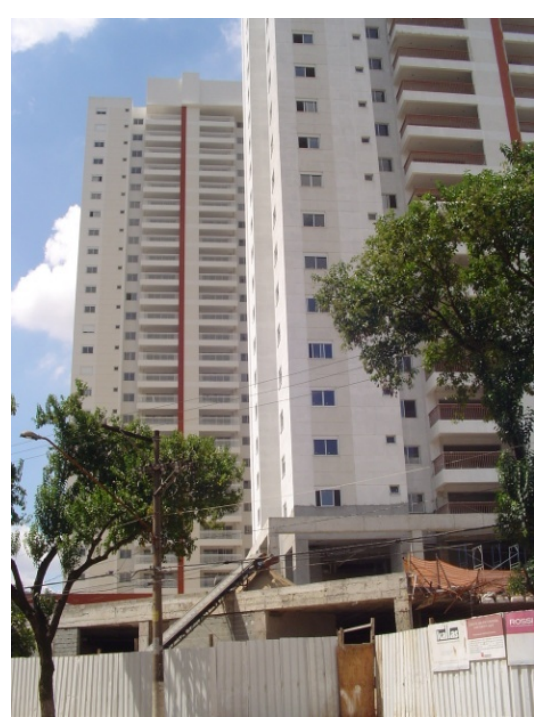

Foto 42 - Empreendimento imobiliário na avenida Mofarrej, Vila Leopoldina

Foto do autor

O simples fato de a área ter abrigado, em algum momento no passado, uma atividade potencialmente contaminadora justifica a realização de um processo inicial de investigação, visando à confirmação ou não desta hipótese.

A constatação da contaminação já exige uma série de outros procedimentos com o objetivo de verificar o grau e a extensão do problema, os tipos de contaminantes presentes no local, além de definir as providências necessárias, no caso da implantação de algum empreendimento, seja ele público ou privado.

Do ponto de vista imobiliário, a existência de contaminação pode ser traduzida como sinônimo de desvalorização e, em muitas situações, a recuperação da área e o tempo necessário para executá-la podem implicar custos consideráveis e incompatíveis com aqueles que o mercado requer para ter um investimento rentável no menor prazo possível. Reside justamente neste fato um dos principais motivos para a resistência dos empreendedores imobiliários aos procedimentos definidos pelo poder público para o gerenciamento de áreas contaminadas. A legislação brasileira, por sua vez, trata a questão sob a perspectiva da responsabilidade objetiva, ou seja, independentemente de culpa, o proprietário ou possuidor de uma área contaminada será responsável pela sua recuperação ambiental, resguardado o direito de acionar judicialmente o verdadeiro causador do dano. 
Na maioria dos casos a recuperação total do solo ou das águas subterrâneas, com a eliminação completa dos poluentes e o retorno ao estado original, não é tecnicamente e/ou economicamente viável, daí trabalhar-se com o conceito de remediação para o uso que se pretende dar à área, que se baseia fundamentalmente na minimização dos riscos.

A região de Jurubatuba, já mencionada anteriormente, tem assistido a uma proliferação de lançamentos imobiliários, favorecida com a alteração do zoneamento pela nova legislação de uso e ocupação do solo de 2004 , num processo de substituição do antigo uso industrial pelo residencial. Por ter sido classificada pela CETESB como "Área Contaminada Crítica", os diversos condomínios de alto padrão em implantação na região não estão autorizados a utilizar a água proveniente de lençóis profundos. Seguindo esta orientação, o GTAC também não tem permitido a construção de pavimentos no subsolo, geralmente destinados a garagens, em razão do impedimento do contato com a água subterrânea no processo de escavação do solo.

Os empreendimentos da região de Jurubatuba, concentrados principalmente no eixo formado pela avenida Eusébio Stevaux, são constituídos por conjuntos de altas torres de apartamentos de alto padrão com imensas varandas e áreas de lazer comuns com múltiplas atividades. Cada condomínio organiza-se como unidade que pouco se relaciona com o entorno imediato, e a sensação de isolamento se intensifica pelo fato de que não haver estabelecimentos comerciais ou de serviços nas imediações, já que era uma região essencialmente industrial (Fotos 43 a 48).

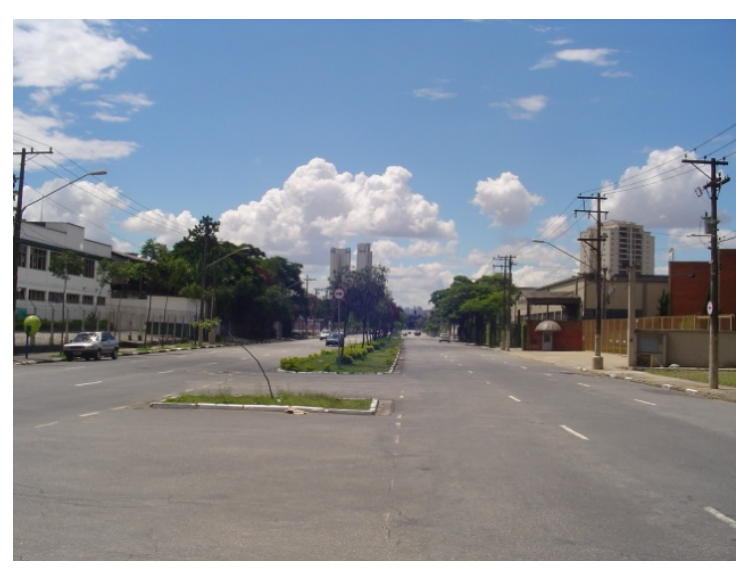

Foto 43 - Vista da avenida Eusébio Stevaux, região de Jurubatuba, Santo Amaro Foto do autor

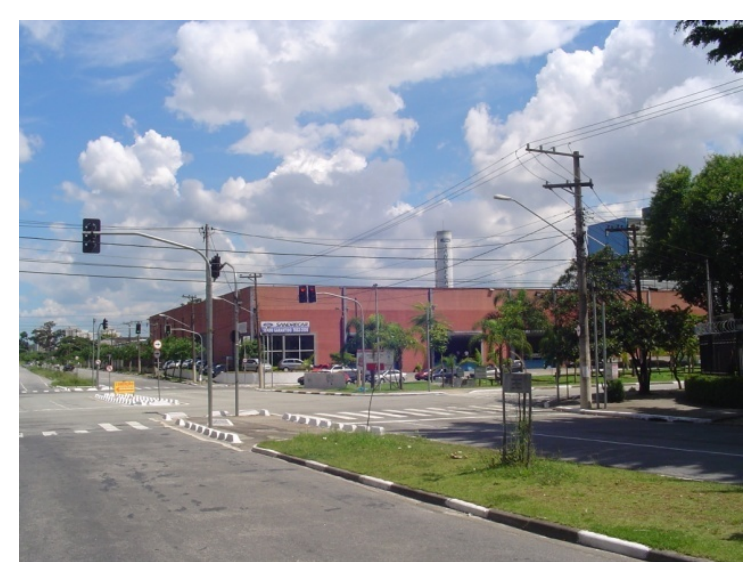

Foto 44 - Mudança de uso na av.Eusébio Stevaux, região de Jurubatuba, Santo Amaro Foto de autor 


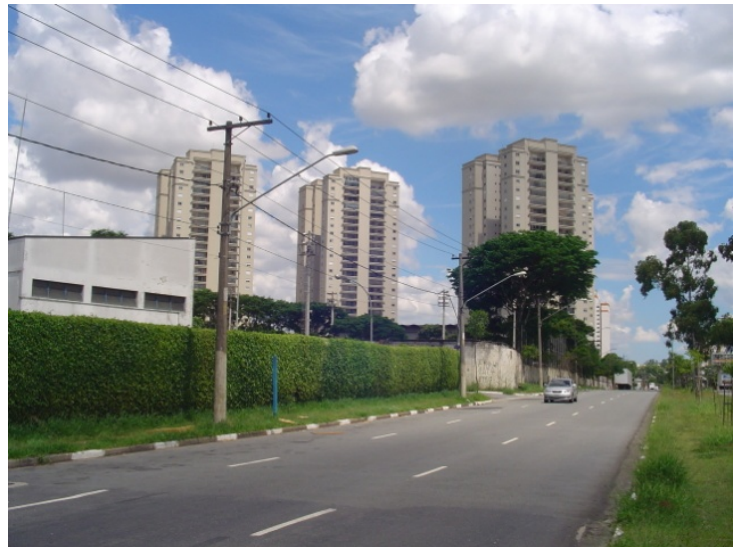

Foto 45 - Condomínio residencial de alto padrão na avenida Eusébio Stevaux, região de Jurubatuba, Santo Amaro

Foto do autor

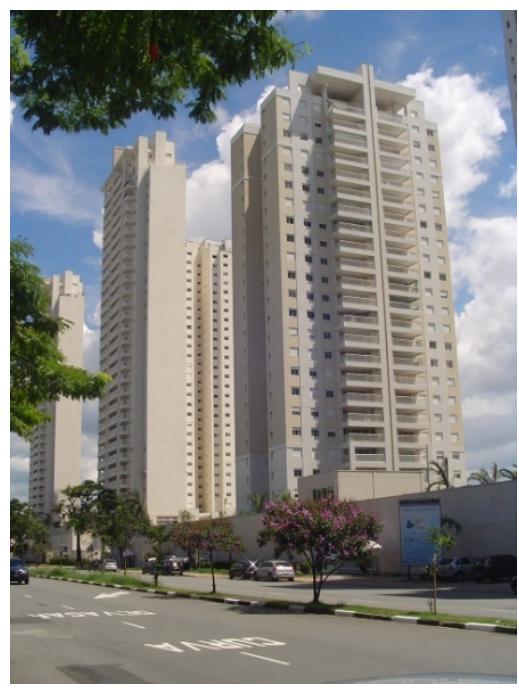

Foto 47 - Novos empreendimentos imobiliários na avenida Eusébio Stevaux, região de Jurubatuba, Santo Amaro

Foto do autor

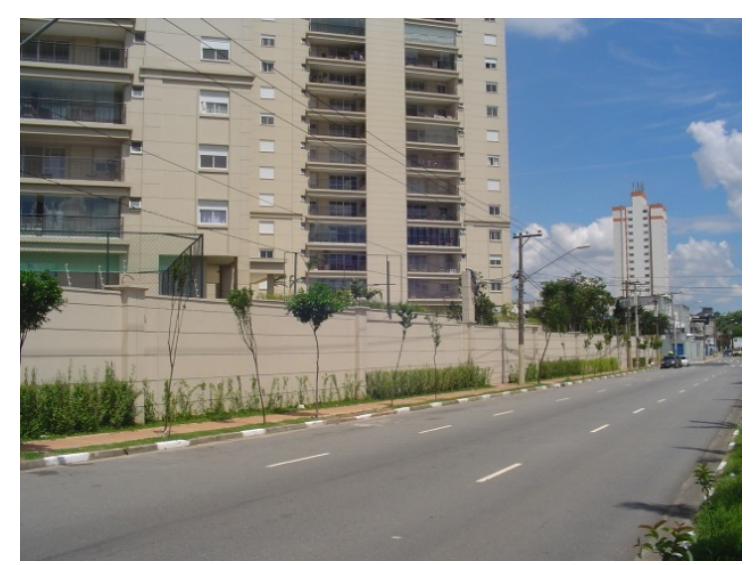

Foto 46 - Condomínio residencial de alto padrão na avenida Eusébio Stevaux, região de Jurubatuba, Santo Amaro

Foto do autor

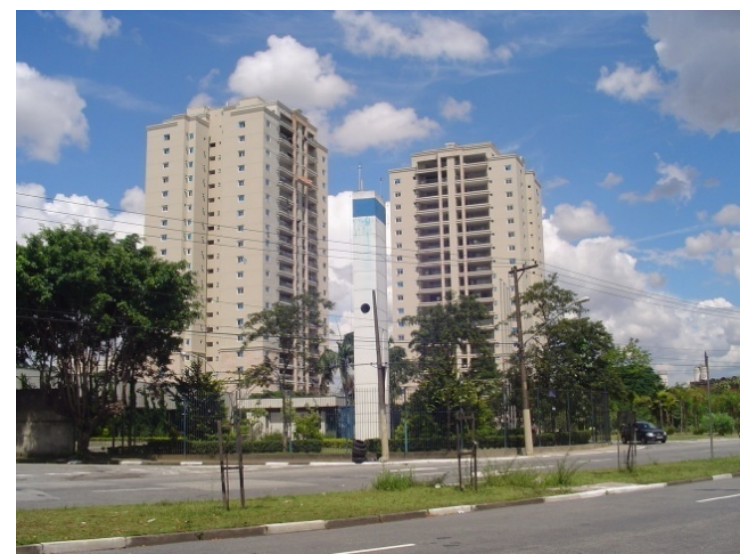

Foto 48 - Novos empreendimentos na avenida Eusébio Stevaux, região de Jurubatuba, Santo Amaro

Foto do autor

De modo semelhante, a construção de novos empreendimentos imobiliários na Vila Leopoldina, predominantemente residenciais, vem ocorrendo principalmente ao longo da avenida Mofarrej, até alguns anos atrás uma via de uso essencialmente industrial, seguindo a mesma tendência e os mesmos padrões de ocupação observados na região de Jurubatuba. Verifica-se também a reutilização de antigos galpões industriais com novas funções, como empresas produtoras de vídeo e estacionamentos (Fotos 49 a 54).

A Relação de Áreas Contaminadas da CETESB, de dezembro de 2011, registra sete áreas na avenida Mofarrej, em diferentes etapas de gerenciamento, 
enquanto o Relatório de Áreas Contaminadas do Município de São Paulo, de janeiro de 2013, assinala quatro, sendo apenas uma delas comum a ambas as listas.

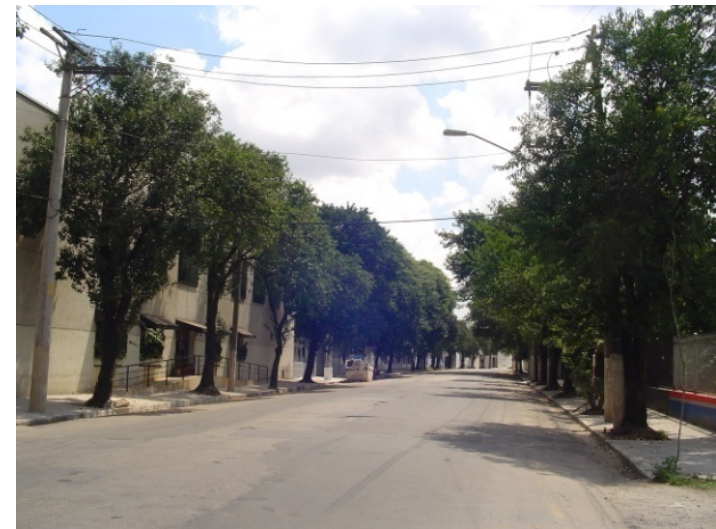

Foto 49 - Vista geral da avenida Mofarrej, Vila Leopoldina

Foto do autor



Foto 51 - Terreno destinado a empreendimento imobiliário na avenida Mofarrej, Vila Leopoldina, temporariamente utilizado como estacionamento

Foto do autor



Foto 53 - Novos empreendimentos em construção na avenida Mofarrej, Vila Leopoldina

Foto do autor

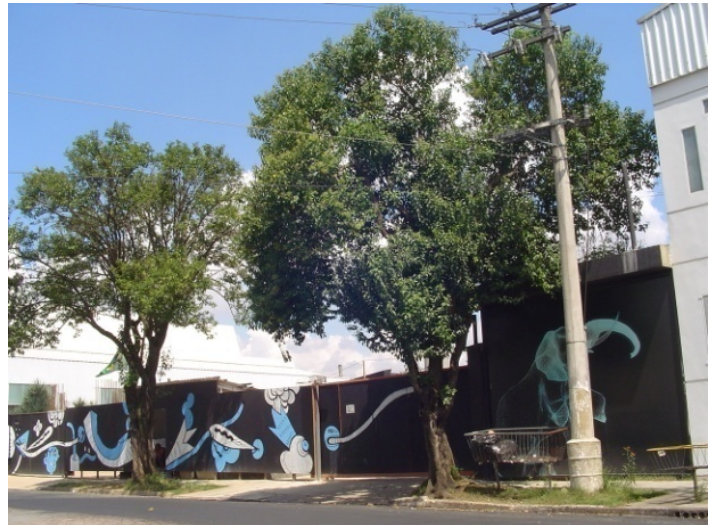

Foto 50 - Terreno destinado a empreendimento imobiliário na avenida Mofarrej, Vila Leopoldina

Foto do autor

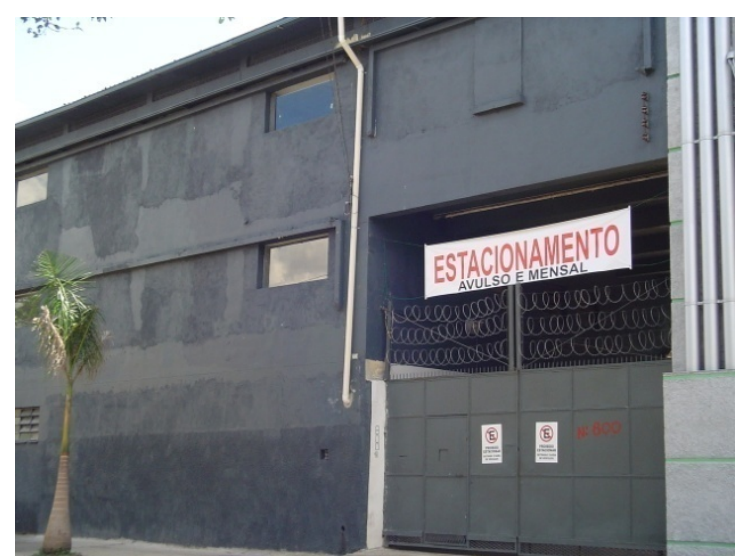

Foto 52 - Galpão industrial com mudança de uso na avenida Mofarrej, Vila Leopoldina

Foto do autor



Foto 54 - Novos empreendimentos em construção na avenida Mofarrej, Vila Leopoldina Foto do autor 
A região da Mooca, um dos berços do processo de industrialização da cidade, apresenta uma diversidade de padrões de ocupação do solo, configurando paisagens distintas. Dessa forma, os antigos galpões industriais, muitos deles ainda em funcionamento, estão presentes na avenida Henry Ford (Foto 55) e em suas imediações, e também na rua Borges de Figueiredo (Foto 56), embora neste último caso já se verifique um processo acelerado de desativação da atividade industrial, com a demolição de alguns deles, o que deu início a um movimento pela preservação dos imóveis remanescentes. Ainda assim, grandes condomínios residenciais já foram implantados naquela vizinhança, onde ainda permanece um padrão de ocupação horizontal. Um deles, construído em terreno anteriormente ocupado por uma das mais antigas metalúrgicas da cidade, entre as ruas Borges de Figueiredo e João A. Oliveira pode ser visto nas Fotos 57 e 58 em diferentes momentos, respectivamente em 2005, época da demolição das edificações existentes, e em 2011, já plenamente ocupado. Enquanto isso, novos empreendimentos vão sendo seguidamente lançados na região, com predominância do uso residencial, apesar de já se observar a instalação de grandes estabelecimentos comerciais, como um shopping center na rua Borges de Figueiredo.



Foto 55 - Vista da avenida Henry Ford, Mooca

Foto do autor

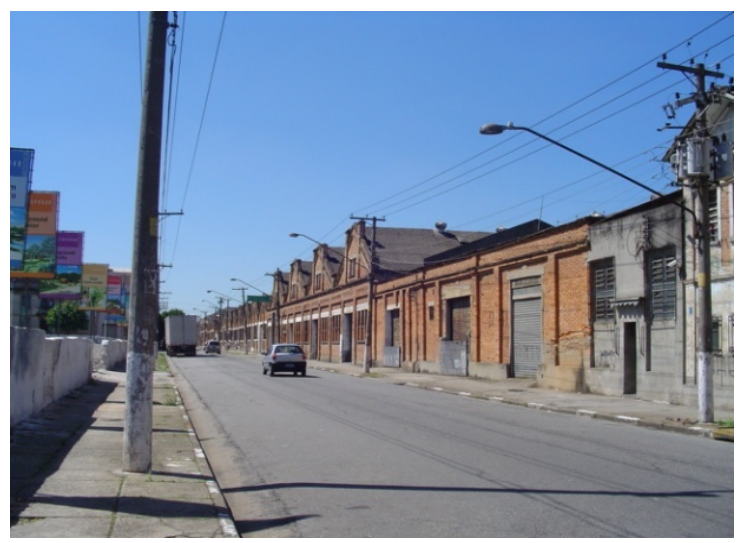

Foto 56 - Vista da rua Borges de Figueiredo, Mooca

Foto do autor 


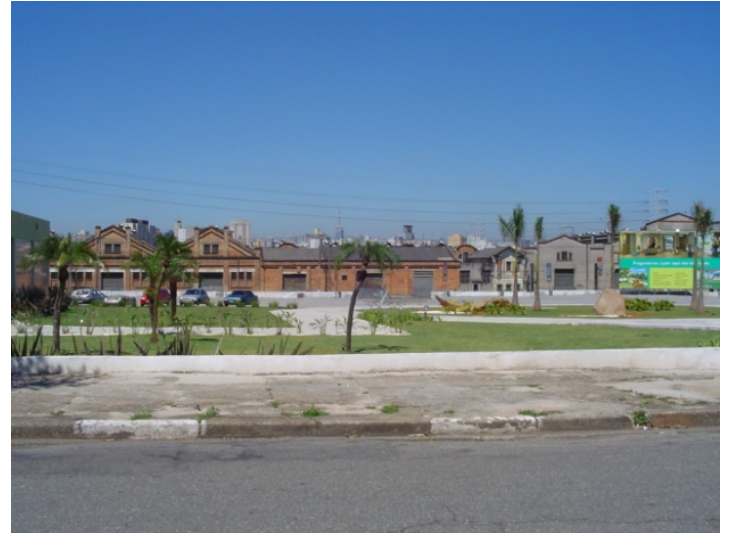

Foto 57 - Vista do terreno na rua João A. Oliveira em 2005, com rua Borges de Figueiredo, ao fundo, na época do lançamento do condomínio residencial.

Foto do autor

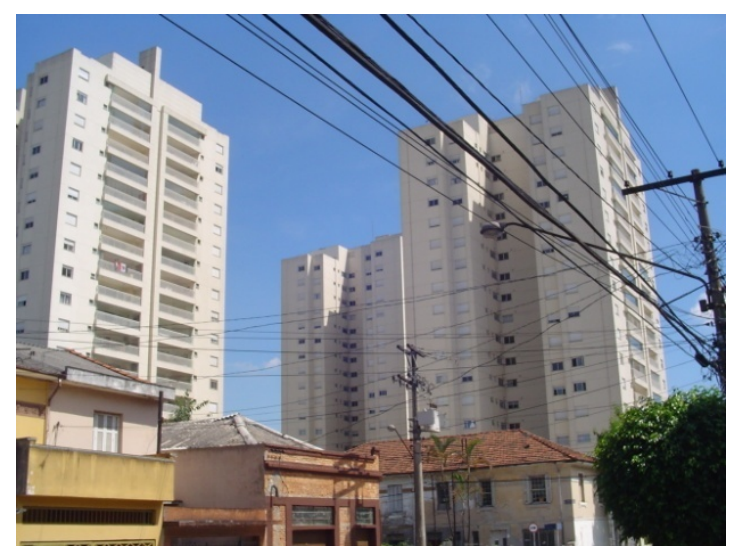

Foto 58 - Vista de condomínio residencial na rua João A. Oliveira em 2011, em terreno anteriormente ocupado por metalúrgica

Foto do autor

Seja em Santo Amaro, seja na Mooca ou na Vila Leopoldina, a situação se repete em espaços idealizados pelo mercado imobiliário como lugares privilegiados e diferenciados, que guardam em comum a existência da contaminação do solo, potencial ou comprovada, e que se não tratada de maneira adequada, pode resultar em consequências danosas aos seus próprios usuários.

\subsection{O gerenciamento de áreas contaminadas sob a perspectiva interdisciplinar e interinstitucional}

A eficiência do gerenciamento de áreas contaminadas depende, sobretudo, de aspectos institucionais, pois envolve questões relativas à atribuição de competências entre diferentes entes governamentais, cujas interfaces devem estar claramente identificadas, de tal modo que procedimentos comuns possam ser previamente acordados e devidamente estabelecidos, evitando assim o surgimento de possíveis conflitos.

Na relação entre Estado e Município, a ausência do convênio entre ambas as esferas de governo, não renovado a partir de 2010, só contribui para dificultar as atividades relativas ao tema, não só do ponto de vista das atribuições, mas também da troca de informações, essencial para agilizar os procedimentos e evitar a duplicidade de ações. No atual contexto, apesar da existência de um canal on line pelo qual a CETESB envia informações sobre áreas contaminadas ao município, o mesmo não tem ocorrido no sentido contrário, segundo informações do GTAC, a não ser em casos específicos. 
Ainda assim, nos procedimentos de aprovação de novos empreendimentos pelo Município, o GTAC tem exigido a apresentação do Plano de Desativação aprovado pela CETESB no caso de estabelecimentos em processo de suspensão ou encerramento de atividades, com base no Decreto Estadual 47.400/2002.

Os aspectos relativos aos procedimentos adotados no nível municipal, pelo GTAC, para identificação, análise e aprovação de projetos em terrenos incluídos no âmbito do gerenciamento de áreas contaminadas já foram abordados no Capítulo 2. Cabe, contudo, ressaltar que projetos em áreas contaminadas implicam necessariamente a análise da correlação entre os aspectos referentes à contaminação, propriamente dita, o seu comportamento no solo e nas águas subterrâneas e a configuração espacial proposta pelo projeto da edificação ou de parcelamento do solo. Sob este ponto de vista, a equipe do GTAC, em agosto de 2012, formada por um biólogo, cinco engenheiros químicos, um químico, uma engenheira civil, três geógrafos e uma física, revela a carência de profissionais da área da geologia, assim como da arquitetura e urbanismo que detenham o conhecimento da legislação de uso e ocupação do solo. Com relação aos geólogos, embora houvesse um concurso público recente para a contratação destes profissionais, a sua efetividade foi praticamente nula, tendo em vista o aquecimento do mercado e os baixíssimos salários oferecidos pela Prefeitura, numa situação semelhante à dos profissionais das áreas de engenharia e arquitetura, que se agrava ano após ano.

A averbação da informação sobre a contaminação de um terreno na matrícula imobiliária tornou-se possível após a Decisão Normativa da Corregedoria-Geral da Justiça do Estado de São Paulo, proferida no Processo CG n 167/2005, que a condiciona à apresentação de termo ou declaração de área contaminada emitida pela CETESB. Nele deve constar a identificação do imóvel afetado, o número do registro aquisitivo, o esclarecimento sobre se trata de contaminação total ou parcial, devendo haver a notificação do proprietário no procedimento administrativo. Note-se que o referido instrumento também foi acolhido pela Lei Estadual no 13.577/2009, que dispõe sobre diretrizes e procedimentos para a proteção da qualidade do solo, mencionada anteriormente.

É importante observar que a ausência de uma efetiva integração de dados entre o órgão ambiental estadual e os órgãos ambientais municipais que já atuam 
com a questão da contaminação e possuem cadastros próprios, como o caso de São Paulo, pode levar à exclusão de imóveis registrados exclusivamente no âmbito municipal. Por outro lado, não se vê motivo para que a emissão do termo ou declaração de área contaminada seja uma tarefa atribuída unicamente ao nível estadual.

A falta de um canal de comunicação oficial e efetivo entre a CETESB e as prefeituras, especialmente de São Paulo, certamente tem levado à não averbação de imóveis contaminados que permanecem apenas no conhecimento do nível municipal, comprometendo a eficácia do mecanismo da averbação. Além disso, corre-se o risco de se exigirem procedimentos em duplicidade por níveis de governo diferentes durante a própria investigação de áreas contaminadas.

Além das questões de cunho exclusivamente técnico, no nível das instituições públicas, a falta de continuidade administrativa torna-se um grande empecilho para a consolidação de projetos e de procedimentos de trabalho, uma vez que as prioridades de ação são modificadas a cada troca de governo, não sendo raro o completo abandono de tudo o que já havia sido feito anteriormente. Soma-se a isto a crescente tendência à desvalorização dos servidores de carreira, além dos baixos salários, o que tem levado a uma situação de grande rotatividade de funcionários, dificultando a manutenção de quadros técnicos estáveis capacitados e comprometidos com a função que exercem e que garantam a continuidade da qualidade dos serviços públicos e a conservação e atualização de um acervo técnico institucional. Certamente a consequência mais preocupante desta situação é a possibilidade de utilização da máquina administrativa para privilegiar ações que não obedeçam ao interesse público, além do agravamento da atuação cada vez mais fragmentada dos órgãos públicos, o que prejudica o desenvolvimento de políticas públicas não só na questão das áreas contaminadas, mas em todos os demais setores de interesse da população. A questão da utilização de instrumentos para o incentivo do reúso de áreas contaminadas chegou a ser objeto de ampla discussão pelos técnicos da Secretaria Municipal do Verde e Meio Ambiente, mas as dificuldades impostas pela própria Administração parecem ter obstado o seu avanço.

O conjunto de todas as circunstâncias até aqui discutidas contribui decididamente para alongar o tempo necessário para realizar os procedimentos executados pela administração pública, objeto de queixa do setor empresarial e dos 
cidadãos. Entretanto, no caso do tratamento das áreas contaminadas, deve-se considerar que, em determinadas situações, o próprio processo de remediação exige prazos mais extensos para serem adequadamente executados e, quanto a isso, entende-se que não há o que se discutir.

\subsection{A utilização de instrumentos urbanísticos, econômicos e ambientais destinados à reabilitação de áreas contaminadas, previstos nas legislações municipal e estadual}

A possibilidade de reutilização de áreas contaminadas envolve uma série de fatores técnicos, econômicos, legais e ambientais, mas nem sempre se viabiliza exclusivamente por meio da atuação do setor privado e dos mecanismos de mercado. As experiências internacionais, sobretudo a norte-americana e a europeia, apontam para a necessidade da instituição de um arcabouço legal, assim como da criação de instrumentos públicos que permitam alavancar o processo de recuperação de tais áreas, de maneira segura, tanto para investidores como para seus futuros usuários, além de mecanismos que possibilitem a participação dos atores envolvidos no processo.

Segundo Marker (2003), as políticas públicas que visam incentivar a reabilitação de áreas contaminadas caracterizam-se pela criação de fundos públicos destinados ao financiamento das ações de investigação e remediação, de incentivos fiscais, de mecanismos de cooperação entre os setores público e privado, além da flexibilização da responsabilidade legal e da vinculação dos padrões de remediação aos usos pretendidos. O estabelecimento de tais políticas surge como consequência de um processo contínuo que, de forma geral, parte de uma postura mais restritiva e se modifica ao longo do tempo, procurando atender às necessidades ambientais e às demandas da sociedade, como se verifica na legislação dos Estados Unidos e nos procedimentos relativos ao tema, adotados pela USEPA.

No Brasil, a legislação federal em vigor trata do tema de forma dispersa, enquanto o estado e o município de São Paulo já dispõem de legislação específica sobre o assunto. O princípio de que o causador do dano é o responsável pelo seu reparo, presente na legislação ambiental brasileira, aponta no sentido de que os incentivos para a recuperação de áreas contaminadas sejam concedidos, a princípio, àqueles que não tenham concorrido para a ocorrência do problema. 
Do ponto de vista urbano, a aprovação do Estatuto da Cidade, por meio da Lei Federal $n^{\circ}$ 10.257/01, constitui um marco fundamental para a definição de instrumentos que devem balizar o desenvolvimento social e ambientalmente equilibrado da cidade, com base na função social da cidade e da propriedade urbana.

O Plano Diretor do Município de São Paulo (PDE), aprovado pela Lei 13.430/02, adota os instrumentos da política urbana instituídos pelo Estatuto da Cidade, acrescido de outros. O PDE e a legislação de uso e ocupação do solo fixam parâmetros para a ocupação de lotes, em função da zona de uso em que se encontram e, para tanto, definem um coeficiente de aproveitamento mínimo, abaixo do qual se considera que a propriedade não cumpre sua função social, e básico, que equivale à área que pode ser construída sem ônus para o proprietário. O direito de utilizar o potencial construtivo superior ao básico só pode ser exercido mediante o pagamento de contrapartida financeira, segundo o mecanismo da outorga onerosa, até o limite do coeficiente de aproveitamento máximo.

Embora não haja previsão legal, na aprovação de projetos em áreas contaminadas, a isenção integral ou parcial do pagamento da outorga onerosa, condicionada à realização da remediação, poderia ser empregada como forma de incentivo ao reúso de terrenos. Nestas condições, o Certificado de Conclusão do imóvel somente deveria ser concedido quando todos os procedimentos exigidos pelo órgão ambiental competente para garantir a segurança dos usuários estivessem implementados. Esta hipótese, portanto, dependeria de alterações na legislação atual, lembrando que a utilização da outorga onerosa só é possível se houver disponibilidade de estoque de potencial construtivo no distrito em que se localiza o imóvel. Vale observar que as Habitações de Interesse Social (HIS) já gozam de isenção total do pagamento da contrapartida financeira, quando o coeficiente de aproveitamento básico é ultrapassado, não cabendo, portanto, a aplicação de tal incentivo.

No Município de São Paulo, o proprietário de imóvel urbano, público ou privado, poderá ser autorizado a exercer o seu direito de construir em outro local, passível de receber o potencial construtivo não utilizado, ou aliená-lo, parcial ou totalmente, nas seguintes situações: implantação de equipamentos urbanos e comunitários; preservação, quando for considerado de interesse histórico, ambiental, 
paisagístico, social ou cultural; para servir a programas de regularização fundiária, urbanização de áreas ocupadas por população de baixa renda e habitação de interesse social.

De modo similar, seria possível considerar a aplicação do mecanismo da transferência para terrenos contaminados, nas situações em que a remediação para o uso que se pretende dar ao imóvel inviabilizasse a utilização do potencial construtivo integral do terreno. Esta possibilidade, no entanto, dependeria de uma alteração da legislação em vigor, e ainda para que ela existisse, seria necessário que a Municipalidade dispusesse de ferramentas que permitissem um controle estrito do potencial construtivo utilizado em cada Distrito, uma vez que numa eventual mudança de uso de um terreno já remediado que tivesse utilizado a transferência do direito de construir, o exercício dessa prerrogativa se tornaria inexequível. Seria o caso, por exemplo, de uma área contaminada que sofresse um processo de impermeabilização do solo para a instalação de um estacionamento descoberto e tivesse todo o potencial construtivo remanescente transferido para outro imóvel; nesta condição não haveria mais a possibilidade de utilização do terreno para a implantação de uma nova edificação, tendo em vista que o potencial construtivo já teria sido totalmente empregado em outro local.

O direito de preempção, outro instrumento previsto pelo PDE, dá preferência ao poder público para a aquisição de imóvel urbano objeto de alienação onerosa entre particulares, em áreas previamente delimitadas pelo referido plano ou nos Planos Regionais Estratégicos, para as seguintes finalidades: I - regularização fundiária; II - execução de programas e projetos habitacionais de interesse social; III - constituição de reserva fundiária; IV - ordenamento e direcionamento da expansão urbana; V - implantação de equipamentos urbanos e comunitários; VI - criação de espaços públicos de lazer e áreas verdes; VII - criação de unidades de conservação ou proteção de outras áreas de interesse ambiental e VIII - proteção de áreas de interesse histórico, cultural ou paisagístico.

Os imóveis inseridos nas áreas de incidência do direito de preempção, colocados à venda no prazo de cinco anos, a partir de edição de lei municipal, devem ser obrigatoriamente oferecidos ao Município. Havendo interesse de terceiros pela aquisição do imóvel, o proprietário deve notificar tal intenção ao Município, que pode manifestar a sua pretensão de exercer o seu direito de preferência no prazo de 
trinta dias. Verifica-se, assim, certa limitação à possibilidade do uso de tal instrumento, considerando a necessidade de a área estar delimitada no Plano Diretor, assim como a dependência da disponibilidade de recursos financeiros pela Municipalidade e da intenção do proprietário de vender o bem.

Como ocorre nas desapropriações, quando a preempção envolve áreas contaminadas, os custos estimados para executar as investigações e a remediação devem ser considerados para efeito de cálculo do valor a ser pago ao proprietário.

A concessão urbanística consiste num instrumento pelo qual o poder público delega a realização de obras de urbanização ou reurbanização de uma determinada área da cidade, a uma empresa ou a um consórcio de empresas, mediante processo licitatório, cuja remuneração será obtida por meio da exploração econômica dos terrenos e edificações resultantes da obra e dos espaços públicos.

Considerando que a concessionária é responsável pelo pagamento das indenizações decorrentes de desapropriações e aquisições de imóveis, quando estes se enquadrarem no âmbito do gerenciamento de áreas contaminadas, é imprescindível que os custos despendidos nas investigações e eventualmente na remediação sejam incorporados ao cálculo dos respectivos valores. A aplicação deste instrumento em áreas com potencial de contaminação implica a necessidade de se realizar procedimentos investigatórios, cujas informações devem ser tomadas como condicionantes na elaboração dos projetos básico e executivo do plano urbanístico, também de responsabilidade da concessionária, da mesma forma que o gerenciamento e a execução das obras.

A Lei $n^{\circ} 14.917$, de 07/05/09, que dispõe sobre a concessão urbanística no Município de São Paulo, define-a como "instrumento de intervenção urbana estrutural destinado à realização de urbanização ou de reurbanização de parte do território municipal a ser objeto de requalificação da infraestrutura urbana e de reordenamento do espaço urbano com base em projeto urbanístico específico em área de operação urbana ou área de intervenção urbana para atendimento de objetivos, diretrizes e prioridades estabelecidas na lei do plano diretor estratégico". É com base nesta lei que o Executivo Municipal realizou a contratação do consórcio que vinha desenvolvendo os trabalhos visando à reabilitação da área denominada Nova Luz, região central da cidade, próxima à Estação da Luz e conhecida pelo intenso tráfico de drogas. Desde o seu início, o projeto vinha sendo objeto de 
controvérsias, por envolver questões polêmicas como a transferência da responsabilidade de execução das desapropriações à iniciativa privada, representada pela empresa concessionária, ou a extensão das desapropriações necessárias para a implantação das obras pretendidas. A perspectiva da ocorrência de um processo de gentrificação, com a expulsão dos moradores de baixa renda e do tradicional comércio popular de produtos eletroeletrônicos, foi outro aspecto debatido com grande intensidade entre o poder público e a população local, durante as discussões sobre o projeto.

A lei estabelece diretrizes que podem justificar a realização de intervenção urbana, mediante a concessão urbanística, entre as quais:

- elevar a qualidade do ambiente urbano, por meio da preservação dos recursos naturais e da proteção do patrimônio histórico, artístico, cultural, urbanístico, arqueológico e paisagístico;

- promover e tornar mais eficientes, em termos sociais, ambientais, urbanísticos e econômicos, os investimentos dos setores público e privado;

- recuperar áreas degradadas ou deterioradas visando à melhoria do meio ambiente e das condições de habitabilidade;

- estimular a reestruturação e requalificação urbanística para melhor aproveitamento de áreas dotadas de infraestrutura, estimulando investimentos e revertendo o processo de esvaziamento populacional ou imobiliário;

- estimular o adensamento de áreas já dotadas de serviços, infraestrutura e equipamentos, de forma a otimizar o aproveitamento da capacidade instalada e reduzir custos.

Com base nos termos da Lei no 14.917/09, verifica-se a aplicabilidade da concessão urbanística na reabilitação de antigas áreas industriais em processo de mudança de uso e, consequentemente, na reabilitação de áreas contaminadas. Tendo em vista que a remuneração da concessionária se dá, por sua conta e risco, "por meio da alienação ou locação de imóveis, inclusive dos imóveis desapropriados e das unidades imobiliárias a serem construídas, da exploração direta ou indireta de áreas públicas na área abrangida pela intervenção urbana ou qualquer outra forma de receita alternativa, complementar ou acessória, bem como pela receita de 
projetos associados", a sua aplicação certamente estaria limitada a áreas que pudessem apresentar melhores condições de rentabilidade para o mercado.

Diferentemente da concessão urbanística, o consórcio imobiliário apresentase como uma espécie de contrato e destina-se às situações em que o proprietário do imóvel não dispõe de condições financeiras para realizar a sua utilização e, por sua iniciativa, o transfere ao poder público, que poderá promover o seu melhor aproveitamento, de forma direta ou indireta, por meio de concessão urbanística ou outra modalidade de contratação. Como pagamento o proprietário recebe unidades imobiliárias devidamente urbanizadas ou edificadas, cujo valor corresponderá àquele do terreno anteriormente à execução das obras, devendo ainda a indenização exprimir o valor da base de cálculo do Imposto Predial e Territorial Urbano, deduzido o montante incorporado em função das obras realizadas e excluídas as expectativas de ganhos, lucros e juros compensatórios.

O instrumento aplica-se não só aos imóveis sujeitos à obrigação legal de parcelar, edificar ou utilizar, os quais, portanto, não cumprem a função social da propriedade, mas também aos que, mesmo não abrangidos pela lei do Plano Diretor Estratégico, sejam necessários às intervenções urbanísticas por ele previstas. Embora exista, de um lado, o interesse do poder público de promover a transformação urbana de uma determinada área, e de outro, o do proprietário privado de realizar o aproveitamento do seu terreno, no caso de uma área contaminada, o consórcio imobiliário torna-se menos vantajoso à medida que se elevam os custos de remediação, principalmente quando se considera que os valores de referência de qualidade do solo são mais exigentes para o uso residencial.

Num nível mais abrangente, em termos territoriais, estão as Áreas de Intervenção Urbana (AIUs) que constituem porções da cidade de especial interesse para o desenvolvimento urbano, nas quais poderão ser aplicados os instrumentos de intervenção previstos no Estatuto da Cidade, com a finalidade de promover "regularização fundiária, execução de programas e projetos habitacionais de interesse social, constituição de reserva fundiária, ordenamento e direcionamento da expansão urbana, implantação de equipamentos urbanos e comunitários, criação de espaços públicos de lazer e áreas verdes, criação de unidades de conservação ou proteção de outras áreas de interesse ambiental". Dentro deste escopo, de acordo 
com o PDE, as AIUs poderão ser destinadas à implantação de Operações Urbanas Consorciadas, Projetos Estratégicos, parques lineares, eixos e polos de centralidade, rede viária estrutural, rede estrutural de transporte coletivo ou áreas envoltórias do Rodoanel.

A criação de Áreas de Intervenção Urbana depende da aprovação de uma lei que deve disciplinar a aplicação de instrumentos, em particular a outorga onerosa e a transferência do direito de construir, devendo ser objeto de elaboração de um Projeto Urbanístico Específico (PUE). Dependendo das características do projeto que for objeto da AIU, será necessário realizar o processo de licenciamento ambiental, quando poderá ser abordado o aspecto da contaminação, especialmente em função do histórico de uso do solo verificado na região. Da mesma forma, o PUE deverá necessariamente considerar a contaminação como uma das condicionantes de projeto, com base numa estratégia que dê um tratamento adequado à questão.

Embora as Operações Urbanas Consorciadas (OUC) constituam um dos casos de Área de Intervenção Urbana, elas possuem especificidades que as tornam um instrumento distinto que apresenta grande interação com os setores do mercado. São definidas no PDE como "o conjunto de medidas coordenadas pelo Município com a participação dos proprietários, moradores, usuários permanentes e investidores privados, com o objetivo de alcançar transformações urbanísticas estruturais, melhorias sociais e a valorização ambiental, notadamente ampliando os espaços públicos, organizando o transporte coletivo, implantando programas habitacionais de interesse social e de melhorias de infraestrutura e sistema viário, num determinado perímetro".

A criação de cada operação urbana prevista no Plano Diretor depende da edição de uma lei municipal específica, como determina o Estatuto da Cidade, a qual definirá a sua área de abrangência, a finalidade e as regras de funcionamento e controle, podendo, ainda, prever a emissão de Certificados de Potencial Adicional de Construção (CEPACs), alienados em leilões ou utilizados no pagamento da área construída que supera os índices estabelecidos pela legislação de uso e ocupação do solo, até o limite fixado pela lei específica.

É exatamente por meio da modificação dos índices e das características de parcelamento, uso e ocupação do solo e subsolo, assim como das alterações das 
normas edilícias, que ocorrem as principais transformações urbanísticas nas áreas de operações urbanas.

Diversas operações urbanas consorciadas delimitadas no PDE estão situadas em antigas regiões industriais da cidade, que passam por um processo de transformação de usos, despertando grande interesse do mercado imobiliário, fato que as tornam fundamentais do ponto de vista do gerenciamento de áreas contaminadas. No que diz respeito às Operações Urbanas Consorciadas, é imprescindível que tal aspecto seja abordado a partir da elaboração do Estudo de Impacto Ambiental, quando poderão ser identificadas as porções no interior do perímetro com maior potencial de contaminação, o que deverá orientar a preparação dos respectivos planos urbanísticos. É importante ressaltar que a aprovação dos projetos específicos para cada empreendimento a ser implantado na área da operação urbana deve ser acompanhada das respectivas investigações ambientais exigidas pelo órgão ambiental municipal.

Considerando que a remediação de áreas contaminadas pode representar uma parcela significativa do custo da implantação de um empreendimento, ainda que não haja previsão legal da utilização dos CEPACs para tal finalidade, esta é uma possibilidade que deveria ser considerada em áreas de OUC.

É interessante observar que o Projeto de Lei no 671/2007, que propunha a revisão e a sistematização do Plano Diretor Estratégico em vigor, estabelecia a obrigatoriedade da elaboração de um Plano da Operação Urbana, como parte da lei específica, o qual deveria contemplar um projeto urbanístico "consistente em desenhos e esquemas, fotos e maquetes, tabelas e gráficos, memoriais e planilhas, todos os elementos tecnicamente pertinentes, adequados e aptos a caracterizar os objetivos e diretrizes, inclusive programas e projetos complementares, parâmetros e procedimentos para as intervenções públicas e para os novos empreendimentos imobiliários e para empreendimentos em parceria com o poder público [...]". O projeto de lei ainda estabelecia que, entre as medidas previstas na lei que instituísse a operação urbana, poderia constar a aplicação de instrumentos e mecanismos de incentivo aos proprietários para a investigação de áreas suspeitas e contaminadas, bem como a remediação de áreas contaminadas.

$\mathrm{Na}$ atual configuração legal, o potencial construtivo obtido a partir da aquisição de CEPACs pode ser utilizado para a implantação de empreendimentos 
imobiliários localizados em qualquer porção do perímetro delimitado pelas operações urbanas, de acordo com a conveniência do empreendedor, e a existência de um projeto urbanístico certamente poderia direcionar o adensamento de determinadas áreas e ordenar a ocupação territorial, de forma compatível com a infraestrutura urbana e viária existente, considerando inclusive o potencial de contaminação dos terrenos.

Uma das condições essenciais para viabilizar a realização de investigações em áreas contaminadas, assim como das remediações necessárias ao seu adequado reúso, é a disponibilidade de recursos financeiros. Atualmente o Município de São Paulo dispõe do Fundo de Desenvolvimento Urbano (FUNDURB), previsto no Plano Diretor, que tem como finalidade concretizar "os objetivos, diretrizes, planos, programas e projetos urbanísticos e ambientais integrantes ou decorrentes da lei do PDE". O FUNDURB é constituído por recursos provenientes do orçamento, de empréstimos, contribuições, resultados financeiros da concessão urbanística e da outorga onerosa do direito de construir, todos eles depositados numa conta vinculada ao fundo.

O Fundo Municipal de Meio Ambiente (FEMA), vinculado à Secretaria Municipal do Verde e do Meio Ambiente - SVMA, foi criado pela Lei $n^{\circ}$ 13.155/2001 e posteriormente revogada pela Lei no 14.887/2009, que incorporou o seu conteúdo. Destina-se prioritariamente a apoiar o controle, a fiscalização e a defesa do meio ambiente, bem como "o desenvolvimento de planos, programas e projetos: a) que visem o uso racional e sustentável de recursos naturais; b) de manutenção, melhoria e/ou recuperação da qualidade ambiental; c) de pesquisa e atividades ambientais". Os seus recursos poderão se aplicados direta ou indiretamente pela SVMA ou transferidos, mediante convênios, termos de parceria, acordos, ajustes ou outros instrumentos previstos em lei.

Entende-se que os procedimentos de investigação e remediação de áreas contaminadas em áreas públicas municipais enquadram-se tanto no escopo do FUNDURB como do FEMA e, portanto, poderiam ser beneficiados por seus recursos, embora não se tenha informações sobre esse tipo de aplicação. É possível considerar a utilização dos recursos provenientes de tais fundos especialmente de forma integrada a outros instrumentos urbanísticos já citados. Certamente a maior 
limitação ao uso de tais fundos em áreas contaminadas reside na disponibilidade de recursos e no fato de que eles atendem a uma série de outras finalidades.

Um instrumento de caráter coercitivo incluído no PDE, que tem sido utilizado pelo poder público para impor obrigações aos causadores de danos ambientais, no sentido de que promovam a sua reparação, é o Termo de Ajustamento de Conduta (TAC), a ser firmado "com pessoas físicas ou jurídicas responsáveis pela construção, instalação, ampliação e funcionamento de estabelecimentos e atividades utilizadores de recursos ambientais, considerados, efetiva ou potencialmente, poluidores".

De acordo com o PDE, o TAC deve fixar obrigações e condicionantes técnicas ao infrator, de modo que os efeitos negativos sobre o meio ambiente, causados pela atividade degradadora, sejam cessados, adaptados, recompostos, corrigidos ou minimizados. No que se refere aos sítios contaminados, o TAC seria aplicável, por exemplo, nas situações em que o infrator, mesmo dispondo de recursos financeiros para arcar com a remediação, não se dispusesse a tomar as providências necessárias para sanar ou minimizar os impactos decorrentes da fonte poluidora.

Nos termos da Lei Federal n 6.938/81, que dispõe sobre a Política Nacional de Meio Ambiente, o PDE estabeleceu que "a localização, construção, instalação, ampliação, modificação e operação de empreendimentos e atividades, utilizadores de recursos ambientais, considerados efetiva ou potencialmente poluidores, bem como os empreendimentos e atividades capazes, sob qualquer forma, de causar significativa degradação ambiental, de acordo com a Resolução CONAMA nº 001/86 ou legislação que venha a sucedê-la", deverão ser objeto de licenciamento pelo órgão ambiental municipal competente, mediante a avaliação de Estudo de Impacto Ambiental e respectivo Relatório de Impacto Ambiental (EIARIMA).

Nas situações em que os impactos ambientais estiverem relacionados basicamente a alterações das características urbanas do entorno, os empreendimentos ou as atividades geradores de tais perturbações estarão sujeitos à avaliação de Estudo de Impacto de Vizinhança e do respectivo Relatório de Impacto de Vizinhança (EIVI/RIVI) pelo órgão ambiental municipal competente, previamente à emissão das licenças ou alvarás de construção, reforma ou funcionamento. Cabe ressaltar que o Relatório de Impacto de Vizinhança já vinha sendo utilizado no 
Município de São Paulo desde a década de 1990, mas somente após a aprovação do Estatuto da Cidade ele foi incorporado ao Plano Diretor Estratégico.

O Estudo de Impacto Ambiental surgiu no Direito Norte-Americano, no final dos anos sessenta, como exigência para projetos de obras governamentais que pudessem causar alterações na qualidade do meio ambiente, dentro de uma sociedade na qual o nível de participação e de mobilização da população é bastante significativo. Embora pudessem exercer um papel relevante no levantamento e gerenciamento de áreas contaminadas, no Brasil, especialmente nos projetos de iniciativa pública, os instrumentos de análise de impactos ambientais têm sido frequentemente tratados como mero procedimento formal e utilizados como meio de avalizar empreendimentos de interesse dos governos, cujos impactos nem sempre são mitigáveis ou compensáveis. Vale lembrar que a elaboração de tais estudos cabe sempre ao responsável pelo empreendimento. Exemplos recentes desta prática são a Usina de Belo Monte, no rio Xingu, estado do Pará, contrariando o parecer de diversos especialistas, e a ampliação das faixas da Marginal do rio Tietê, na cidade de São Paulo, onde houve a supressão de grande parte dos canteiros centrais da via em benefício do transporte individual. Além disso, no Município de São Paulo, há casos de empreendimentos e projetos que tiveram a aprovação de EIA/RIMAs e RIVIs quando a sua implantação já se encontrava em pleno andamento.

Apesar de não incluído entre os instrumentos urbanísticos do PDE, a inserção do reajuste fundiário havia sido proposto no projeto de revisão do plano enviado à Câmara Municipal, pelo Projeto de Lei n 671/2007. Trata-se de um mecanismo originalmente concebido no Japão, no período pós-guerra, que permitiria o rearranjo de uma área urbana contida num determinado perímetro, mediante a alteração das dimensões e da disposição de lotes e glebas, com base num Projeto Urbanístico Específico - PUE e a adesão de todos os proprietários. O reajuste fundiário teria como objetivo obter melhorias urbanísticas, ganho de áreas públicas e de qualidade ambiental, garantindo o cumprimento da função social da propriedade, podendo ser empregado somente nas áreas de Operações Urbanas Consorciadas e Áreas de Intervenção Urbana.

Considerando regiões com disseminação da contaminação por áreas mais extensas, o reajuste fundiário poderia tornar-se interessante ao possibilitar o 
rearranjo da configuração de lotes e glebas. Talvez a maior dificuldade esteja na necessidade da concordância da totalidade dos proprietários, tanto com relação à utilização do instrumento como também para as alterações que viessem a ser propostas, o que, sem dúvida, implicaria um amplo processo de negociação e um tempo maior para a sua execução, nem sempre compatível com os tempos políticos.

O registro em cartório da contaminação existente nos imóveis é um dispositivo já previsto pela Lei Estadual no 13.577/09. Esta informação, no entanto, nem sempre é repassada aos compradores das futuras edificações a serem erguidas nestas áreas, como demonstra reportagem do jornal "Folha de São Paulo", de 09/08/2010. Em um dos casos citados, o morador de um empreendimento localizado no Alto da Boa Vista manifesta desconhecimento a respeito da contaminação alegada pela CETESB, embora a incorporadora afirmasse que a obra, executada no final dos anos 1990, estivesse em situação totalmente regularizada. No outro caso mencionado, a moradora de um condomínio no Parque dos Príncipes, zona oeste da cidade, assegura não ter sido informada, no momento da compra do imóvel, sobre a contaminação das águas subterrâneas causada por uma antiga indústria anteriormente existente no local, ainda que a incorporadora declarasse que esta condição constava do memorial descritivo e da convenção do prédio.

A mesma lei estadual também instituiu o Fundo Estadual para Prevenção e Remediação de Áreas Contaminadas (FEPRAC), fundo de investimento vinculado à Secretaria do Meio Ambiente, especialmente criado para ser utilizado na proteção do solo e nas ações de identificação e remediação de áreas contaminadas. A lei prevê a possibilidade de aplicação dos recursos do FEPRAC, a fundo perdido, nas situações em que o seu tomador for o Estado, com o objetivo de intervir em área contaminada, para eliminar perigo iminente à saúde pública, devendo, neste caso, o responsável legal pela área efetuar o ressarcimento ao Estado pelos custos decorrentes da identificação e remediação.

O Decreto $n^{0} 54.544 / 09$, ao regulamentar a Lei $n^{0} 13.577 / 09$, estabeleceu 0 recolhimento de valores pelo empreendedor ao FEPRAC, a título de compensação ambiental, quando do "licenciamento ambiental de empreendimento cuja atividade seja potencialmente passível de gerar área contaminada".

De uma forma geral, a utilização de instrumentos fiscais e urbanísticos em áreas contaminadas sofre grande influência de fatores como a sua localização e o 
grau de interesse que despertam no setor imobiliário. Certamente, conforme este interesse diminui, cresce a necessidade da interferência do poder público para induzir o processo de recuperação ambiental, ou mesmo para obrigar que ele se concretize por meio dos mecanismos que procuram garantir o cumprimento da função social da propriedade urbana.

Independentemente da existência de instrumentos de incentivo, um aspecto que ainda cria dificuldades para a recuperação ambiental de áreas contaminadas diz respeito à responsabilização jurídica, segundo a qual se atribui ao proprietário ou possuidor do imóvel afetado a responsabilidade pela realização da remediação do local, mesmo que não tenha sido o causador do problema, resguardado o seu direito de ser ressarcido pelo verdadeiro responsável, por meio de ação cível. Note-se que, mesmo nos Estados Unidos, esta ainda é uma das principais preocupações dos empreendedores privados, apesar da flexibilização legal da responsabilização em áreas contaminadas.

Desta forma, o uso de mecanismos de incentivo à revitalização de áreas contaminadas pressupõe a existência de um ambiente no qual os diversos setores da administração pública, nos diferentes níveis de governo, trabalhem de forma integrada, interinstitucional e interdisciplinar, exatamente no sentido oposto da situação atual, na qual são muito raros os exemplos de interação entre os agentes públicos.

Do ponto de vista das áreas contaminadas, a utilização dos instrumentos até aqui abordados, isoladamente ou no contexto de planos urbanos, teria como finalidade básica promover a reabilitação desses terrenos, permitindo o seu retorno ao ciclo econômico, assim como o próprio redesenho de trechos da cidade, dentro de condições que assegurassem a manutenção da saúde dos usuários e do meio ambiente e garantissem o controle futuro do uso do solo, em função das restrições remanescentes à sua ocupação. A revitalização de áreas contaminadas e o emprego dos instrumentos adequados a cada situação podem ser enquadrados, portanto, no rol das ações que visam à sustentabilidade ambiental, desde que realizadas sob a perspectiva de uma racionalidade ambiental que implique mudanças das condições socioeconômicas com o aperfeiçoamento da relação do homem com a natureza, como ressalta Montibeller (2004). 
Os exemplos internacionais procuram inserir o tratamento de áreas contaminadas no âmbito de projetos de desenvolvimento local ou de urbanização, o que, em princípio, tenderia a facilitar os processos de investigação e remediação de terrenos afetados pelo problema, principalmente nos casos em que a contaminação ultrapassa os limites de um único lote. O Tax Increment Financing (TIF), utilizado nos Estados Unidos, ilustra esta visão e surge como um instrumento interessante, ao vincular a valorização dos imóveis privados, obtida a partir da realização de investimentos públicos em uma determinada região da cidade, à cobrança de um valor adicional em forma de tributo, para o redesenvolvimento de determinadas áreas urbanas e a recuperação de áreas contaminadas. De maneira análoga, seria possível cogitar a criação de Áreas de Intervenção Urbana (AIUs) com finalidade semelhante às áreas TIF, utilizando-se a Contribuição de Melhoria, prevista no Plano Diretor Estratégico, como meio para se obter o retorno da valorização resultante das intervenções implementadas pelo poder público. Assim como ocorre com outros instrumentos urbanísticos, alguns críticos apontam o risco da gentrificação na aplicação deste instrumento, visto que a valorização dos imóveis tenderia a expulsar as famílias com menor renda.

Mesmo assim, ainda que uma determinada região seja objeto de um plano urbanístico, do ponto de vista do gerenciamento de áreas contaminadas, é necessário que as soluções de projeto dos empreendimentos nele inseridos sejam analisadas caso a caso, sem prejuízo de diretrizes mais genéricas, pois tais soluções dependem de fatores específicos do terreno, entre eles, os tipos e as concentrações dos contaminantes, o sentido do fluxo das águas subterrâneas e a extensão da pluma de contaminação.

O rigor inicial da legislação americana no tratamento de áreas contaminadas foi sendo substituída, no decorrer do tempo, pela flexibilização dos níveis de remediação, associada ao tipo de uso pretendido, bem como da responsabilidade legal, o que foi acompanhada pela criação de novos mecanismos, como a figura do "proprietário inocente", já citada anteriormente.

O caso alemão também demonstra a preocupação em colocar o tratamento de áreas contaminadas integrados a projetos de desenvolvimento urbano, especialmente por meio de empresas e organismos concebidos especificamente para tal finalidade. 
A instituição de fundos próprios para a avaliação e remediação de áreas contaminadas, assim para a pesquisa de novas tecnologias de remediação, caracterizam as políticas desenvolvidas por países com maior experiência nesse campo. Os fundos atualmente disponíveis na cidade de São Paulo destinam-se a finalidades diversas e nem sempre possuem recursos suficientes para atender a todas as demandas. Por outro, o fundo estadual recentemente instituído ainda não tem regulamentação e deverá cobrir as solicitações de todos os municípios do estado.

Outro aspecto importante a se ressaltar com relação à situação dos países mais desenvolvidos diz respeito à existência de sistemas eficientes de registro de informações, que dão suporte ao desenvolvimento de políticas públicas e de projetos urbanos. No Brasil, e especificamente em São Paulo, a presença de uma significativa parcela da cidade construída à margem das normas urbanísticas e ambientais dificulta a constituição de uma base de dados, ou mesmo a formulação de projetos para estas áreas.

De qualquer modo, há que se considerar que a simples transposição de mecanismos existentes em outros países para o contexto brasileiro não se mostra adequada, considerando que as condições institucionais e legais aqui presentes nem sempre condizem com aquelas necessárias à sua implementação.

Por outro lado, a adoção de mecanismos que privilegiam as parcerias entre os setores público e privado neste campo deve ser examinada com a devida cautela para que os objetivos econômicos e administrativos não acabem se sobrepondo aos aspectos relativos à justiça ambiental, comprometendo 0 sentido da sustentabilidade, conforme observam alguns críticos nos Estados Unidos, com relação às políticas voltadas à reabilitação de áreas contaminadas naquele país.

A propósito, de acordo com Acselrad et al (2004, p.10), o conceito de justiça ambiental desenvolve-se a partir da capacidade dos movimentos sociais norteamericanos, particularmente das organizações envolvidas na luta pelos direitos civis das populações afrodescentes na década de 1960, de perceber os reclamos de parcelas da população mais pobre e socialmente discriminada pelo fato de estarem mais expostas a riscos ambientais, principalmente pela sua proximidade de depósitos de resíduos químicos e radioativos ou indústrias poluidoras. Desde então, passou-se a consolidar o entendimento de que a justiça ambiental é constituída por 
um "conjunto de princípios que asseguram que nenhum grupo de pessoas, sejam grupos étnicos, raciais ou de classe, suporte uma parcela desproporcional de degradação do espaço coletivo".

Nos Estados Unidos, uma das consequências mais evidentes do fortalecimento do movimento por justiça ambiental pode ser observado no campo da legislação, por exemplo, com a implementação de procedimentos para a descontaminação de terrenos e a criação de mecanismos que garantem o direito à informação e a fundos direcionados para as comunidades vizinhas afetadas, além do acesso ao conhecimento de detalhes sobre empreendimentos existentes ou em implantação.

A questão da justiça ambiental no Brasil está intimamente relacionada à existência situações de desigualdades sociais extremas disseminadas pelo país, não se configurando apenas como um problema de maior ou menor exposição aos riscos ambientais, mas também de apropriação do território e dos recursos naturais e aos seus benefícios, que acabam por se concentrar nas mãos de uma pequena minoria que detém o poder político e econômico.

O quadro a seguir apresenta, de forma sucinta, os instrumentos e mecanismos aqui abordados, apontando as suas possíveis formas de aplicação bem como as dificuldades e limitações para a sua utilização. 


\begin{tabular}{|c|c|c|c|}
\hline \multirow{2}{*}{\begin{tabular}{|c|}
$\begin{array}{c}\text { Instrumentol } \\
\text { Mecanismo }\end{array}$ \\
Outorga onerosa \\
\end{tabular}} & Característica & \multirow{2}{*}{$\begin{array}{l}\text { Possibilidades de aplicação em áreas } \\
\text { contaminadas } \\
\text { Na forma de concessão de isenção integral } \\
\text { ou parcial do pagamento da outorga } \\
\text { onerosa, condicionada à realização da } \\
\text { remediação }\end{array}$} & $\begin{array}{c}\text { Dificuldades de aplicação/limitações em } \\
\text { áreas contaminadas }\end{array}$ \\
\hline & $\begin{array}{l}\text { Direito de utilizar o potencial } \\
\text { construtivo superior ao básico, até o } \\
\text { limite do coeficiente de aproveitamento } \\
\text { máximo, mediante o pagamento de } \\
\text { contrapartida financeira }\end{array}$ & & $\begin{array}{l}\text { Dependência de alterações na legislação } \\
\text { atual e da disponibilidade de estoque de } \\
\text { potencial construtivo no distrito em que se } \\
\text { localiza o imóvel }\end{array}$ \\
\hline $\begin{array}{ll}\text { Transferência } & \text { do } \\
\text { direito } & \text { de } \\
\text { construir } & \end{array}$ & $\begin{array}{l}\text { Exercício do direito de construir em } \\
\text { outro local, passível de receber o } \\
\text { potencial construtivo não utilizado, ou } \\
\text { aliená-lo, parcial ou totalmente }\end{array}$ & $\begin{array}{l}\text { Situações em que a remediação para o uso } \\
\text { que se pretende dar ao imóvel inviabilize a } \\
\text { utilização do potencial construtivo integral do } \\
\text { terreno }\end{array}$ & $\begin{array}{l}\text { Dependência de alterações na legislação } \\
\text { atual }\end{array}$ \\
\hline $\begin{array}{l}\text { Direito } \\
\text { preempção }\end{array}$ & $\begin{array}{l}\text { Preferência ao poder público para a } \\
\text { aquisição de imóvel urbano objeto de } \\
\text { alienação onerosa entre particulares }\end{array}$ & $\begin{array}{l}\text { Aquisição de áreas a serem remediadas para } \\
\text { a implantação de espaços e equipamentos } \\
\text { públicos, devendo os custos estimados para } \\
\text { executar as investigações e a remediação } \\
\text { ser considerados para efeito de cálculo do } \\
\text { valor a ser pago ao proprietário } \\
\end{array}$ & $\begin{array}{l}\text { Necessidade de a área estar previamente } \\
\text { delimitada no Plano Diretor }\end{array}$ \\
\hline $\begin{array}{l}\text { Concessão } \\
\text { urbanística }\end{array}$ & $\begin{array}{l}\text { Poder público delega a realização de } \\
\text { obras de urbanização ou } \\
\text { reurbanização de uma determinada } \\
\text { área da cidade, a uma empresa ou a } \\
\text { um consórcio de empresas, mediante } \\
\text { processo licitatório, cuja remuneração } \\
\text { será obtida por meio da exploração } \\
\text { econômica dos terrenos e edificações } \\
\text { resultantes da obra e dos espaços } \\
\text { públicos }\end{array}$ & $\begin{array}{l}\text { Em áreas com potencial de contaminação ou } \\
\text { comprovadamente contaminadas, é } \\
\text { necessária a realização de procedimentos } \\
\text { investigatórios, cujas informações devem ser } \\
\text { tomadas como condicionantes na elaboração } \\
\text { dos projetos básico e executivo do plano } \\
\text { urbanístico, assim como no gerenciamento e } \\
\text { na execução das obras. }\end{array}$ & $\begin{array}{l}\text { Maior possibilidade de aplicação em áreas } \\
\text { com melhores condições de rentabilidade } \\
\text { para o mercado }\end{array}$ \\
\hline $\begin{array}{l}\text { Consórcio } \\
\text { imobiliário }\end{array}$ & $\begin{array}{l}\text { forma de contrato destinado às } \\
\text { situações em que o proprietário do } \\
\text { imóvel não dispõe de condições } \\
\text { financeiras para realizar sua utilização } \\
\text { e, por sua iniciativa, o transfere ao } \\
\text { poder público para promover o seu } \\
\text { melhor aproveitamento, de forma } \\
\text { direta ou indireta, por meio de } \\
\text { concessão urbanística ou outra } \\
\text { modalidade de contratação }\end{array}$ & $\begin{array}{l}\text { Aplicação não só aos imóveis sujeitos à } \\
\text { obrigação legal de parcelar, edificar ou } \\
\text { utilizar, mas também aos que, mesmo não } \\
\text { abrangidos pela lei do PDE, sejam } \\
\text { necessários às intervenções urbanísticas por } \\
\text { ele previstas, possibilitando o reúso de } \\
\text { terrenos contaminados }\end{array}$ & $\begin{array}{l}\text { Instrumento sem regulamentação na } \\
\text { legislação municipal, torna-se menos } \\
\text { vantajoso à medida que se elevam os custos } \\
\text { de remediação, principalmente quando se } \\
\text { considera que os valores de referência de } \\
\text { qualidade do solo são mais exigentes para o } \\
\text { uso residencial }\end{array}$ \\
\hline
\end{tabular}




\begin{tabular}{|c|c|c|c|}
\hline $\begin{array}{l}\text { Áreas } \\
\text { Intervenção } \\
\text { Urbana (AIU) }\end{array}$ & $\begin{array}{l}\text { Porçães da cidade de especial } \\
\text { interesse para o desenvolvimento } \\
\text { urbano, nas quais poderão ser } \\
\text { aplicados os instrumentos de } \\
\text { intervenção previstos no Estatuto da } \\
\text { Cidade, com a finalidade de promover } \\
\text { "regularização fundiária, execução de } \\
\text { programas e projetos habitacionais de } \\
\text { interesse social, constituição de } \\
\text { reserva fundiária, ordenamento e } \\
\text { direcionamento da expansão urbana, } \\
\text { implantação de equipamentos urbanos } \\
\text { e comunitários, criação de espaços } \\
\text { públicos de lazer e áreas verdes, } \\
\text { criação de unidades de conservação } \\
\text { ou proteção de outras áreas de } \\
\text { interesse ambiental" }\end{array}$ & $\begin{array}{l}\text { Em AlUs que contenham áreas com } \\
\text { potencial de contaminação ou } \\
\text { comprovadamente contaminadas, é } \\
\text { necessária a realização de procedimentos } \\
\text { investigatórios, cujas informações devem ser } \\
\text { tomadas como condicionantes na elaboração } \\
\text { do Plano Urbanístico Específico (PUE), } \\
\text { assim como no gerenciamento e na } \\
\text { execução das obras }\end{array}$ & \\
\hline $\begin{array}{l}\text { Operações } \\
\text { Urbanas } \\
\text { Consorciadas } \\
\text { (OUC) }\end{array}$ & $\begin{array}{l}\text { "Conjunto de medidas coordenadas } \\
\text { pelo Município com a participação dos } \\
\text { proprietários, moradores, usuários } \\
\text { permanentes e investidores privados, } \\
\text { com o objetivo de alcançar } \\
\text { transformações } \\
\text { estruturais, melhorias sociais e a } \\
\text { valorização ambiental, notadamente } \\
\text { ampliando os espaços públicos, } \\
\text { organizando o transporte coletivo, } \\
\text { implantando programas habitacionais } \\
\text { de interesse social e de melhorias de } \\
\text { infraestrutura e sistema viário, num } \\
\text { determinado perímetro" }\end{array}$ & $\begin{array}{l}\text { Em OUCs que contenham áreas com } \\
\text { potencial de contaminação ou } \\
\text { comprovadamente contaminadas, é } \\
\text { necessária a realização de procedimentos } \\
\text { investigatórios, cujas informações devem ser } \\
\text { tomadas como condicionantes na elaboração } \\
\text { dos planos urbanísticos, assim como no } \\
\text { gerenciamento e na execução das obras. } \\
\text { Possibilidade da utilização de CEPACs para } \\
\text { realização da investigação e da remediação } \\
\text { de áreas contaminadas }\end{array}$ & $\begin{array}{l}\text { Inexistência de previsão legal para } \\
\text { utilização dos CEPACs, na investigação } \\
\text { remediação de áreas contaminadas }\end{array}$ \\
\hline $\begin{array}{l}\text { Fundo de } \\
\text { Desenvolvimento } \\
\text { Urbano } \\
\text { (FUNDURB) }\end{array}$ & $\begin{array}{l}\text { Fundo criado com a finalidade } \\
\text { concretizar "os objetivos, diretrizes, } \\
\text { planos, programas e projetos } \\
\text { urbanísticos e ambientais integrantes } \\
\text { ou decorrentes da lei do PDE" }\end{array}$ & $\begin{array}{l}\text { Utilização para a realização de investigações } \\
\text { em áreas contaminadas, assim como das } \\
\text { remediações necessárias ao seu adequado } \\
\text { reúso }\end{array}$ & $\begin{array}{l}\text { Dependência da disponibilidade de recursos } \\
\text { e o fato de atender a uma série de outras } \\
\text { finalidades }\end{array}$ \\
\hline
\end{tabular}




\begin{tabular}{|c|c|c|c|}
\hline $\begin{array}{lr}\text { Fundo } & \text { Municipal } \\
\text { de } & \text { Meio } \\
\text { Ambiente (FEMA) }\end{array}$ & $\begin{array}{l}\text { Fundo destinado prioritariamente a } \\
\text { apoiar o controle, a fiscalização e a } \\
\text { defesa do meio ambiente, bem como } \\
\text { "o desenvolvimento de planos, } \\
\text { programas e projetos: a) que visem o } \\
\text { uso racional e sustentável de recursos } \\
\text { naturais; b) de manutenção, melhoria } \\
\text { e/ou recuperação da qualidade } \\
\text { ambiental; c) de pesquisa e atividades } \\
\text { ambientais" }\end{array}$ & $\begin{array}{l}\text { Utilização para a realização de investigações } \\
\text { em áreas contaminadas, assim como das } \\
\text { remediações necessárias ao seu adequado } \\
\text { reúso }\end{array}$ & $\begin{array}{l}\text { Dependência da disponibilidade de recursos } \\
\text { e o fato de atender a uma série de outras } \\
\text { finalidades }\end{array}$ \\
\hline $\begin{array}{l}\text { Termo de } \\
\text { Ajustamento de } \\
\text { Conduta (TAC) }\end{array}$ & $\begin{array}{l}\text { Instrumento de caráter coercitivo } \\
\text { firmado "com pessoas físicas ou } \\
\text { jurídicas responsáveis pela } \\
\text { construção, instalação, ampliação e } \\
\text { funcionamento de estabelecimentos e } \\
\text { atividades utilizadores de recursos } \\
\text { ambientais, considerados, efetiva ou } \\
\text { potencialmente, poluidores" }\end{array}$ & $\begin{array}{l}\text { Aplicação em situações nas quais o infrator, } \\
\text { mesmo dispondo de recursos financeiros } \\
\text { para arcar com a remediação, não se } \\
\text { dispusesse a tomar as providências } \\
\text { necessárias para sanar ou minimizar os } \\
\text { impactos decorrentes da fonte poluidora }\end{array}$ & \\
\hline $\begin{array}{l}\text { Estudo } \\
\text { Impacto } \\
\text { Ambiental }\end{array}$ & $\begin{array}{l}\text { Documento a ser elaborado nos casos } \\
\text { de empreendimentos e atividades com } \\
\text { significativo potencial poluidor e de } \\
\text { degradação ambiental }\end{array}$ & $\begin{array}{l}\text { Obrigatoriedade da abordagem dos impactos } \\
\text { decorrentes da existência de contaminação } \\
\text { do solo e das águas subterrâneas nos } \\
\text { empreendimentos ou projetos que abranjam } \\
\text { áreas com potencial de contaminação ou } \\
\text { comprovadamente contaminadas }\end{array}$ & $\begin{array}{l}\text { Frequentemente tratados como mero } \\
\text { procedimento formal e utilizados como meio } \\
\text { de avalizar empreendimentos, especialmente } \\
\text { de iniciativa pública, cujos impactos nem } \\
\text { sempre são mitigáveis ou compensáveis }\end{array}$ \\
\hline $\begin{array}{l}\text { Relatório } \\
\text { Impacto } \\
\text { Vizinhança }\end{array}$ & $\begin{array}{l}\text { Documento a ser elaborado nas } \\
\text { situações em que os impactos } \\
\text { ambientais estiverem relacionados } \\
\text { basicamente a alterações das } \\
\text { características urbanas do entorno }\end{array}$ & $\begin{array}{l}\text { Obrigatoriedade da abordagem dos impactos } \\
\text { decorrentes da existência de contaminação } \\
\text { do solo e das águas subterrâneas nos } \\
\text { empreendimentos ou projetos que abranjam } \\
\text { áreas com potencial de contaminação ou } \\
\text { comprovadamente contaminadas }\end{array}$ & $\begin{array}{l}\text { Frequentemente tratados como mero } \\
\text { procedimento formal e utilizados como meio } \\
\text { de avalizar empreendimentos, cujos } \\
\text { impactos nem sempre são mitigáveis ou } \\
\text { compensáveis }\end{array}$ \\
\hline $\begin{array}{l}\text { Reajuste } \\
\text { fundiário }\end{array}$ & $\begin{array}{l}\text { Instrumento que permite o rearranjo de } \\
\text { uma área urbana contida num } \\
\text { determinado perímetro, mediante a } \\
\text { alteração das dimensões e da } \\
\text { disposição de lotes e glebas, com } \\
\text { base num Projeto Urbanístico } \\
\text { Específico - PUE e a adesão de todos } \\
\text { os proprietários }\end{array}$ & $\begin{array}{l}\text { Considerando regiões com disseminação da } \\
\text { contaminação por áreas mais extensas, } \\
\text { possibilitaria o rearranjo da configuração de } \\
\text { lotes e glebas }\end{array}$ & $\begin{array}{l}\text { Proposto no projeto de revisão do Plano } \\
\text { Diretor Estratégico (Projeto de Lei } n^{\circ} \\
671 / 2007 \text { ), requer a concordância da } \\
\text { totalidade dos proprietários e tempos mais } \\
\text { longos de negociação }\end{array}$ \\
\hline
\end{tabular}




\begin{tabular}{|c|c|c|c|}
\hline $\begin{array}{lr}\text { Registro } & \text { em } \\
\text { cartório } & \text { da } \\
\text { contaminação } & \\
\text { existente } & \end{array}$ & $\begin{array}{l}\text { Dispositivo já previsto pela Lei } \\
\text { Estadual n } n^{\circ} 13.577 / 09 \text {, determina ao } \\
\text { responsável pela área contaminada } \\
\text { que proceda no prazo de até cinco } \\
\text { dias à averbação da informação da } \\
\text { contaminação da área na respectiva } \\
\text { matrícula imobiliária }\end{array}$ & & $\begin{array}{l}\text { Dificuldade de ações interinstitucionais para } \\
\text { integração das informações nos diferentes } \\
\text { níveis de governo }\end{array}$ \\
\hline $\begin{array}{l}\text { Fundo Estadual } \\
\text { para Prevenção e } \\
\text { Remediação de } \\
\text { Áreas } \\
\text { Contaminadas } \\
\text { (FEPRAC) }\end{array}$ & $\begin{array}{l}\text { Fundo de investimento vinculado à } \\
\text { Secretaria do Meio Ambiente, } \\
\text { especialmente criado para ser utilizado } \\
\text { na proteção do solo e nas ações de } \\
\text { identificação e remediação de áreas } \\
\text { contaminadas }\end{array}$ & & $\begin{array}{l}\text { Ausência de regulamentação, além da } \\
\text { disponibilidade de recursos e o fato de } \\
\text { atender a todo o estado de São Paulo }\end{array}$ \\
\hline $\begin{array}{l}\text { Responsabilidade } \\
\text { legal }\end{array}$ & $\begin{array}{l}\text { Atribuição ao proprietário ou possuidor } \\
\text { do imóvel afetado da responsabilidade } \\
\text { pela realização da remediação do } \\
\text { local, mesmo que não tenha sido o } \\
\text { causador do problema, resguardado o } \\
\text { seu direito de ser ressarcido pelo } \\
\text { verdadeiro responsável, por meio de } \\
\text { ação cível (Responsabilidade objetiva) }\end{array}$ & $\begin{array}{l}\text { Flexibilização legal da responsabilização, } \\
\text { nos casos em que o proprietário ou } \\
\text { possuidor do imóvel não for o causador da } \\
\text { contaminação }\end{array}$ & $\begin{array}{l}\text { Dependência de alterações na legislação } \\
\text { atual }\end{array}$ \\
\hline $\begin{array}{l}\text { Transposição de } \\
\text { mecanismos } \\
\text { existentes em } \\
\text { outros países l } \\
\text { Mecanismos que } \\
\text { privilegiam ras } \\
\text { parcerias entre } \\
\text { os setores } \\
\text { público e privado }\end{array}$ & & & $\begin{array}{l}\text { De forma geral, inexistência das condições } \\
\text { legais e institucionais necessárias à à } \\
\text { implementação da maioria dos mecanismos } \\
\text { Necessidade de cautela para que os } \\
\text { objetivos econômicos e administrativos não } \\
\text { se sobreponham aos aspectos relativos à } \\
\text { justiça ambiental }\end{array}$ \\
\hline
\end{tabular}

Quadro 2 - Instrumentos e mecanismos destinados à reabilitação de áreas contaminadas 


\subsection{A participação da população na remediação de áreas contaminadas}

A efetiva participação da população nas discussões e a tomada de decisões acerca de ações que possam resultar em algum tipo de consequência sobre a vida da coletividade não têm sido uma prática habitual em nosso país, especialmente quando envolve projetos de interesse de determinados grupos ou de grande prioridade para os governos. No campo do meio ambiente, as audiências públicas vêm sendo adotadas como instrumento de participação, porém o que se observa na realidade é o seu uso como subterfúgio para legitimar determinadas ações que raramente garantem alguma qualidade ambiental ou, no mínimo, a mitigação dos danos decorrentes de sua implementação. Observa-se, assim, que o emprego aleatório do termo participação, assim como vários outros, pode dar margem ao uso de acordo com a conveniência de quem dele se apropria, a exemplo do que ocorre com os termos sustentabilidade e transparência.

Teixeira (2001, p. 26) enfatiza a necessidade de se delimitar o conceito de participação e, para tanto, julga fundamental considerar o poder político, não entendido como autoridade ou Estado, mas sob a perspectiva de "uma relação em que atores, com os recursos disponíveis nos espaços públicos, fazem valer seus interesses, aspirações e valores, construindo suas identidades, afirmando-se como sujeitos de direitos e obrigações". A partir deste ponto de vista, as condições sob as quais tais relações ocorrem estariam vinculadas a aspectos como o contexto socioeconômico, a natureza do regime e da cultura política e o seu desenvolvimento histórico, os quais, por sua vez, determinariam o nível de dificuldade encontrado para o exercício de uma efetiva participação.

Assim, Teixeira (2001, p. 30) adota o conceito de participação cidadã, o qual define como "processo complexo e contraditório entre sociedade civil, Estado e mercado, em que os papéis se redefinem pelo fortalecimento dessa sociedade civil mediante a atuação organizada dos indivíduos, grupos e associações", concebendo sociedade civil como ente autônomo, mas que mantém uma estreita relação com o Estado e o mercado, sem a pretensão de substituí-los em suas funções próprias, evitando assim "o corporativismo e os particularismos". Nesse contexto, a participação cidadã faz uso de mecanismos institucionais existentes ou a serem criados, articulando-os a outros canais legitimados pelo processo social. 
De fato, o risco do estabelecimento de vínculos que podem ser entendidos como formas de cooptação exige que as organizações sociais mantenham um certo distanciamento das estruturas de poder, garantindo-Ihes os níveis de independência e isenção necessários para se contrapor aos demais atores envolvidos nessa relação, fato que nem sempre é observado por determinadas organizações do chamado terceiro setor. Além disso, a tentativa de tais entidades de substituir as funções do Estado ou de constituir um poder paralelo a ele, inclusive com o repasse de recursos públicos, pode servir como argumento para a crescente tendência à desoneração do Estado presente em políticas defendidas por determinados segmentos da sociedade.

O papel da participação na tomada de decisões é colocado por Teixeira (2001, p. 35) como questão central no processo democrático, muito embora reconheça as dificuldades para superar os obstáculos à participação nas decisões mais complexas, sem abrir mão das conquistas institucionais e políticas já obtidas. Este fato, no entanto, não impediria a busca de mecanismos que aliem a participação, que representa a diversidade de pontos de vistas dos diferentes grupos sociais, à representação, "que busca traduzir a generalidade, a universalidade da cidadania". Ao mesmo tempo, ressalta a função da participação como instrumento de controle do Estado pela sociedade, não só na forma de prestação de contas, segundo parâmetros socialmente estabelecidos em espaços públicos próprios, mas também por meio da responsabilização dos agentes políticos no exercício de seus atos, com base nas leis e nos padrões éticos vigentes.

É certo que Teixeira realiza uma abordagem ampla acerca do tema da participação, mas entende-se que as suas considerações são bastante pertinentes quando se trata de questões mais particularizadas, como a das áreas contaminadas que pode afetar um número significativo de pessoas. Nesse sentido, há que se reforçar um aspecto fundamental defendido pelo autor com relação ao papel autolimitado da sociedade civil em relação ao Estado e ao mercado, ou seja, o de não lhe caber a função de substituir tais estruturas, mas a de influir nas decisões e na formulação de políticas.

Nos Estados Unidos, o Superfund foi instituído como um programa do governo federal destinado à limpeza de áreas com disposição de resíduos perigosos não controlados, com base no fundo de mesmo nome criado pelo Comprehensive 
Environmental Response Compensation and Liability Act (CERCLA), em 1980. O Superfund dispõe de ações específicas para o envolvimento da comunidade afetada, por meio de um programa próprio, que além do fornecimento de informações, possibilita a sua participação nas decisões que atingem as áreas objeto do programa, durante todas as suas etapas.

De acordo com o Superfund Community Involvement Handbook, publicação da USEPA (2005), a interlocução com a comunidade tem como objetivo estabelecer um trabalho colaborativo para se chegar a uma boa solução para o problema dos resíduos perigosos, de forma que o plano de ação para a área reflita, ao máximo, as inquietações externadas pela população local. Esta relação deve ocorrer por intermédio de uma equipe designada para a área de intervenção, composta por um gerente do projeto de remediação ou um coordenador in loco, ou ambos, um coordenador de envolvimento da comunidade, um gerente de avaliação da área, um procurador e outros membros do corpo técnico. A abordagem inicial mais frequentemente empregada para o entendimento dos interesses e da opinião da comunidade é realizada mediante entrevistas, que resultam em informações utilizadas na elaboração do Plano de Envolvimento da Comunidade, o qual se configura como um instrumento que busca estabelecer estratégias e atividades que possibilitem a compreensão do problema pelas pessoas por ele afetadas e a sua participação na tomada de decisões, durante as diferentes fases do processo de remediação da área.

O Superfund também coloca à disposição das comunidades das áreas incluídas ou com proposta para ser incluídas na Lista de Prioridades Nacional (National Priorities List) a Subvenção para Assistência Técnica (Technical Assistance Grant), que se destina à contratação de consultores independentes para auxiliar na interpretação e compreensão de informações técnicas a respeito das áreas afetadas pela contaminação.

A USEPA ainda abre a possibilidade da formação de Grupos Consultivos Comunitários (Community Advisory Groups), constituídos por membros da comunidade que teriam a função de apresentar e discutir as necessidades e preocupações do grupo com relação ao processo de tomada de decisões do Superfund. Canon (2010) relata que, apesar de estudos da USEPA indicarem a maior efetividade de tais grupos para esclarecer as inquietações da comunidade e 
resolver as questões, comparativamente às reuniões públicas, muito poucas áreas abrangidas pelo programa Superfund dispõem desta alternativa. Entre as razões apontadas para a pequena adesão a este mecanismo estão o nível de organização da comunidade necessário para a formação dos grupos consultivos, os recursos despendidos pela USEPA para acompanhá-los e o aumento do grau de influência que eles podem exercer sobre o processo de decisão, o que poderia causar entraves ao trabalho.

Mesmo dispondo de instrumentos que procuram ampliar a participação da população sobre as resoluções a respeito das áreas contaminadas integrantes do Superfund, alguns críticos constatam problemas na efetividade do modelo proposto para esta finalidade. Dukes (2010), com base em diversos estudos de caso e em sua própria experiência como mediador em trabalhos com a comunidade em áreas contaminadas nos Estados Unidos, faz uma análise pouco animadora sobre o envolvimento da comunidade no atual processo de reabilitação desses terrenos. Relata, por exemplo, a insatisfação e a frustração por parte de trabalhadores do setor público, diante do comportamento indignado de cidadãos que não entendem as regras estabelecidas para a proteção pública ou que desconhecem os aspectos científicos e os riscos que cercam o problema, resultando muitas vezes em malentendidos que geram desconfiança e hostilidade. Por outro lado, contrapõe os argumentos constantemente apresentados pelos cidadãos, que se queixam da recusa dos proprietários dos terrenos contaminados de manter um contato real, ou então da troca periódica dos representantes da USEPA e da falta de informações e do desinteresse de funcionários estaduais e do governo local.

Dukes (2010) vê grandes limitações no modelo padrão de envolvimento da comunidade, especialmente em áreas com severa contaminação do solo à espera de um novo uso, o qual consiste na distribuição de informações e na realização de um determinado número de reuniões nas quais há apenas uma troca de notícias e respostas a questionamentos realizados pelo público. Defende que a decisão sobre o uso do solo cabe mais à comunidade do que à própria USEPA e considera que o sucesso no reúso de áreas contaminadas exige não só a troca de informações, mas a negociação, o acordo e a cooperação entre os interesses e as instituições envolvidas, o que certamente não exclui os conflitos. Como forma de enfrentar o surgimento destes conflitos, propõe a adoção do processo da construção do 
consenso, que combina procedimentos tradicionais, como reuniões públicas, correspondências, rádio e televisão, com grupos de decisão da comunidade e dos atores envolvidos, aliados aos seus instrumentos de diálogo, deliberação e tomada de decisões multilateral.

Quando se trata do nível local, a participação pública na revitalização de brownfields nos Estados Unidos é um assunto controverso na visão de Hula (2012), uma vez que, na perspectiva de empreendedores e autoridades, exigências mais severas neste sentido podem reduzir a velocidade de execução de projetos e, eventualmente, inviabilizá-los. Argumenta-se, neste caso, que os residentes locais tendem a apresentar uma clareza com relação aos benefícios que pretendem obter para as suas comunidades, sem terem ideia da realidade econômica. Os defensores da participação pública, por sua vez, contra-argumentam que o não engajamento da população no processo de planejamento certamente implicaria a sua oposição ao desenvolvimento do projeto, acarretando perdas econômicas significativas na formulação e implementação dos planos.

Cabe aqui mencionar a dissertação de Marcatto (2005), que teve como objetivo avaliar o processo de participação pública no caso da contaminação da Shell, na Vila Carioca, região do Ipiranga, na cidade de São Paulo. O trabalho adota como referencial teórico a Convenção de Aarhus, realizada em 1998, da qual resultou um acordo ambiental estabelecido no âmbito da Comunidade Econômica para a Europa das Nações Unidas, e que se fundamentou em três pilares interdependentes: acesso à informação, participação pública no processo de decisões e acesso à justiça em questões ambientais.

Marcatto (2005) discorre, de forma detalhada, sobre todos os acontecimentos que envolveram o caso da Vila Carioca e os conflitos gerados entre os atores envolvidos, inclusive entre os próprios moradores. Ressalta a importância de se assegurar ao público interessado o entendimento do que ocorre no ambiente e em sua volta, permitindo que as pessoas estejam habilitadas a participar do processo de discussão de uma forma consciente. Destaca, ainda, que "o ideal da participação pública envolve a atuação dos membros da sociedade conjuntamente com autoridades públicas para atingir um resultado mais eficiente no processo decisório" (MARCATTO, 2005, p.33). 
Ao formular subsídios para os órgãos públicos na discussão do processo de participação pública na gestão de áreas contaminadas, Marcatto (2005), propõe procedimentos para promover a interlocução com a população afetada, com base nos três pilares da Convenção de Aarhus e refere-se ao Projeto de Lei $n^{\circ}$ 368/05, que se converteria, anos mais tarde, na Lei Estadual $n^{\circ} 13.577$, de 8 de julho de 2009, que dispõe sobre diretrizes e procedimentos para a proteção da qualidade do solo e gerenciamento de áreas contaminadas, sugerindo a utilização de alguns de seus instrumentos. Recomenda, por exemplo, o uso do Fundo Estadual para Prevenção e Remediação de Áreas Contaminadas, previsto na referida lei, para a contratação de consultor independente, a exemplo do que ocorre no programa federal norte-americano, para dar suporte técnico à população para a análise do Plano de Remediação da Área Contaminada. Entende-se como bastante positiva esta possibilidade, assim que o fundo estiver regulamentado, porém considera-se que esta alternativa deveria estar disponível a partir do momento em que a existência da contaminação fosse confirmada e que a população estivesse minimente organizada.

Por outro lado, verifica-se nas recomendações efetuadas por Marcatto (2005) uma grande ênfase nas atividades de competência estadual, ao passo que a responsabilidade pelas questões relacionadas ao uso e ocupação do solo são atribuições conferidas ao nível municipal pela Constituição Federal.

O grau de participação e de reivindicação, em geral, intensifica-se na medida em que a vida do indivíduo ou os seus interesses são diretamente afetados por determinados problemas ou ações, mas depende também do grau de percepção que se tem deles. A invisibilidade da contaminação provavelmente contribui para que ela só seja notada quando passa a produzir efeitos adversos sobre a saúde da população, ou no momento em que ela começa a representar uma possibilidade de prejuízo ao patrimônio individual.

Recentemente, notícia divulgada pelo jornal "Folha de São Paulo", de 23/07/2012, relata que moradores de um condomínio construído na cidade de São Bernardo do Campo, sobre um terreno anteriormente ocupado por uma indústria de plástico, entraram com ações na Justiça contra uma grande construtora do mercado, sob a alegação de não terem sido comunicados sobre a contaminação existente no terreno, durante a venda dos apartamentos, o que poderia acarretar uma futura 
desvalorização dos imóveis. Neste caso em particular, a CETESB afirmou que o problema era de conhecimento da construtora, pelo menos desde o início de 2011, e que a contaminação por metais pesados em parte do solo e da água subterrânea não oferece risco aos moradores. De acordo com a reportagem, a construtora argumenta que cumpriu todas as exigências do órgão ambiental e que, ao contrário do que afirmam os moradores, sempre alertou os clientes a respeito da contaminação.

O mesmo jornal, em reportagem do dia 21/08/2012, publicou notícia sobre decisão da Justiça de São Paulo, condenando uma construtora a pagar uma indenização no valor de $\mathrm{R} \$ 120$ mil ao comprador de um apartamento em um condomínio no município de Guarulhos, por não tê-lo informado de que o prédio tinha sido implantado sobre uma área contaminada, fato contestado pela empresa que alega ter comunicado que o terreno estava sendo "descontaminado".

A transparência na divulgação sobre os terrenos contaminados na cidade e a desmistificação a respeito do seu reúso podem contribuir para evitar situações como a de São Bernardo do Campo e de Guarulhos, logicamente desde que sejam tomadas todas as medidas para impedir que seus futuros ocupantes sofram os efeitos adversos decorrentes da presença de poluentes no solo e na água subterrânea, sempre sob a orientação dos órgãos ambientais competentes, podendo até tornar-se uma oportunidade de negócios, como ocorre na Alemanha.

A disponibilização de listas de áreas contaminadas, tanto pelo nível estadual como pelo Município de São Paulo, representa um avanço no aspecto de se tornarem públicas informações que são do interesse da coletividade. Do mesmo modo, a possibilidade da averbação da contaminação do imóvel na matrícula imobiliária, ainda restrita ao estado de São Paulo, é uma medida de grande relevância para o gerenciamento de áreas contaminadas, pois facilita o controle do poder público sobre a utilização desses imóveis e permite que futuros compradores tenham conhecimento sobre as reais condições do terreno e possam tomar as devidas providências para aproveitá-lo de maneira adequada. Contudo, não se pode incorrer no erro de estigmatizar tais áreas, a ponto de torná-las inservíveis ou indesejáveis, mas é essencial que a população tome consciência da importância de recuperá-las, dentro de padrões técnicos adequados, e trazê-las de volta ao cotidiano da cidade. 
O fato é que a participação da população no processo de decisão a respeito de questões que exerçam influência sobre a sua vida ainda é bastante incipiente, limitando-se a mecanismos que, muitas vezes, são burocráticos e apenas pretendem legitimar resoluções definidas de forma unilateral. Mesmo dispondo de instrumentos de participação não imagináveis no atual contexto do gerenciamento de áreas contaminadas no Brasil, as críticas aos mecanismos de envolvimento da comunidade, adotados no âmbito do programa Superfund, demonstram a existência de problemas semelhantes aos encontrados aqui. As alternativas propostas para o aperfeiçoamento desse aspecto do programa contêm, sem dúvida, transformações qualitativas muito significativas, que certamente exigem tempos mais longos de maturação e execução, o que, no caso brasileiro, poderia enfrentar oposição, tanto dos setores empresariais como dos políticos, que geralmente demandam soluções de curto prazo.

Diferentemente de práticas observadas nos Estados Unidos, que abrem a possibilidade de participação da população do entorno nas decisões a respeito da definição sobre o uso de imóveis privados em processo de remediação, na cidade de São Paulo, esta definição cabe exclusivamente ao proprietário ou ao empreendedor imobiliário que a submete à apreciação do poder público, a quem cabe deliberar sobre o assunto. Entende-se, no entanto, que em casos nos quais a presença da contaminação gera situações de risco real à saúde e ao patrimônio dos residentes locais, como na Vila Carioca, a população tem todo o direito de conhecer a realidade dos fatos e também de influir nas decisões a respeito das medidas a serem tomadas com relação aos terrenos afetados, inclusive daqueles que deram origem à contaminação, mesmo que estes sejam de propriedade privada.

\subsection{As oportunidades de transformação da paisagem industrial, a partir do tratamento das áreas contaminadas - o exemplo da Mooca}

Meyer \& Grostein (2010) qualificam como fundamental a questão da transformação de uso das áreas industriais, visto que todas as análises ressaltam a importância desse legado territorial, não só pela sua extensão e localização na malha urbana, o que possibilita a utilização de lotes e glebas dotados de infraestrutura pelo setor habitacional, mas também pelo direcionamento do atual modelo de desenvolvimento metropolitano. 
A região da Mooca, em especial nos trechos localizados ao longo do eixo ferroviário e na antiga várzea do rio Tamanduateí, é certamente uma das áreas mais significativas da cidade em termos da transformação histórica de paisagens naturais pela ação humana para o desenvolvimento de atividades econômicas alavancadas pelo setor industrial.

O período posterior à abolição da escravatura e à instauração da República traz significativas transformações sociais com o estabelecimento do regime de trabalho assalariado e o crescimento do fluxo imigratório, sobretudo de europeus, a princípio direcionado para a lavoura cafeeira e posteriormente empregado como mão de obra de uma indústria nascente. O capital acumulado pelo café, inicialmente investido na implantação da infraestrutura necessária ao escoamento do produto, passa a ser aplicado na edificação de armazéns, entrepostos e casas comerciais em áreas urbanas e, posteriormente, na construção de indústrias, em bairros como Água Branca, Barra Funda, Brás, Mooca e Belenzinho.

É justamente nos bairros que vão se constituindo ao longo da orla ferroviária que se instalam as primeiras colônias de imigrantes que, juntamente com os operários, compõem as camadas mais pobres da população, vivendo em áreas densamente ocupadas, em condições de moradia e higiene precárias e sem acesso à maior parte dos serviços públicos, exatamente sobre terrenos frágeis do ponto de vista ambiental, consagrando uma forma de urbanização na qual a ocupação do espaço ocorre a partir das áreas mais próximas aos corpos d'água para as regiões mais altas.

O setor têxtil, sem dúvida o mais importante no período inicial do processo de industrialização paulistana, era uma atividade com grande potencial de contaminação, tanto na fase de beneficiamento de fios e tecidos, durante a qual processos físicos e químicos eram empregados para eliminação das impurezas, quanto na etapa de tingimento, com a utilização de corantes e pigmentos, alguns deles à base de metais pesados. As indústrias química e metalúrgica também constituíam ramos de produção com grande contribuição na geração de contaminantes, da mesma forma que a fabricação de pesticidas.

As condições de terrenos naturalmente alagáveis e com lençol freático elevado das áreas de várzea, sobre as quais foi assentada grande parte do parque industrial mais antigo da cidade, certamente favoreceram o agravamento de 
possíveis ocorrências de contaminação do solo e das águas subterrâneas. Os cursos d'água, por sua vez, fundamentais na estruturação urbana, também sofreram as consequências desse processo de dominação e modificação dos elementos naturais, inserido num contexto de transformação do modo de produção e das relações sociais.

A partir dos anos 40, o modo de transporte rodoviário começa a adquirir grande importância, principalmente com a construção de novas rodovias, o que levou à localização de novos polos industriais em função dessas vias. A opção por este novo modelo de transporte é ratificado pela política econômica brasileira adotada no Plano de Metas, na década de 1950, numa época em que o país já dispunha de uma considerável malha ferroviária.

Laurentino (2002) atenta para o fato de que, embora o uso das estradas de ferro não tivesse cessado com a preferência cada vez maior pelo transporte rodoviário, as empresas localizadas em antigas áreas industriais, à margem da ferrovia, começavam a sentir as dificuldades relacionadas ao transporte de mercadorias por caminhões, por estarem instaladas em regiões nas quais a malha viária era inadequada ao trânsito destes veículos. As mesmas dificuldades eram sentidas pelas indústriais situadas nas áreas de uso misto (residencial e industial), denominadas por Langenbuch (1971) como Zona Mista Sub-Ferroviária. No caso da Mooca e do Ipiranga, a implantação da avenida do Estado, ao longo do Tamanduateí já retificado e canalizado, é apontada como provável fator para a minimização do recuo industrial na região, em relação a outras mais distantes deste corredor viário.

As discussões a respeito do recuo no setor industrial, de acordo com Laurentino (2002), geram uma diversidade de termos para tratar do tema, tais como desconcentração, descentralização, desindustrialização e outros, nem sempre empregados com o devido rigor. A ideia de desconcentração industrial estaria relacionada à dispersão de partes ou mesmo de todas as unidades produtivas de uma empresa num certo espaço, sem o deslocamento da parte administrativa e da gestão, enquanto a descentralização implicaria a mudança do polo de comando para outra cidade ou região, e nesse sentido, o que se observa na Região Metropolitana de São Paulo poderia ser identificado como um processo predominantemente de desconcentração. 
Já para se referir à desindustrialização, Laurentino (2002) baseia-se em Raymond Guglielmo, que utiliza o termo para designar o fim da atividade industrial numa determinada região, sem que ocorra a sua sucessão por outras atividades relacionadas ao processo produtivo, o que colocaria as transformações em curso na área industrial ao longo do Tamanduateí no âmbito da desindustrialização.

O abandono da atividade industrial reflete-se na ociosidade e na demolição das antigas edificações industriais e das instalações ao longo da orla ferroviária, e também na ausência da presença humana nas ruas e na perda das referências espaciais, pessoais e sensoriais, especialmente por parte de antigos moradores e trabalhadores, que passam a conviver com novos usos e novas vizinhanças.

Sob estes aspectos, o Distrito da Mooca (Figura 12), integrante da Subprefeitura de mesmo nome, apresenta-se como área bastante significativa, razão pela qual pretende-se aqui focalizá-la de maneira mais detalhada, para avaliar a possibilidade da aplicação de instrumentos urbanísticos e ambientais que possam promover a requalificação do espaço urbano e da paisagem, concomitantemente à adoção de mecanismos que permitam a recuperação adequada de terrenos contaminados. 


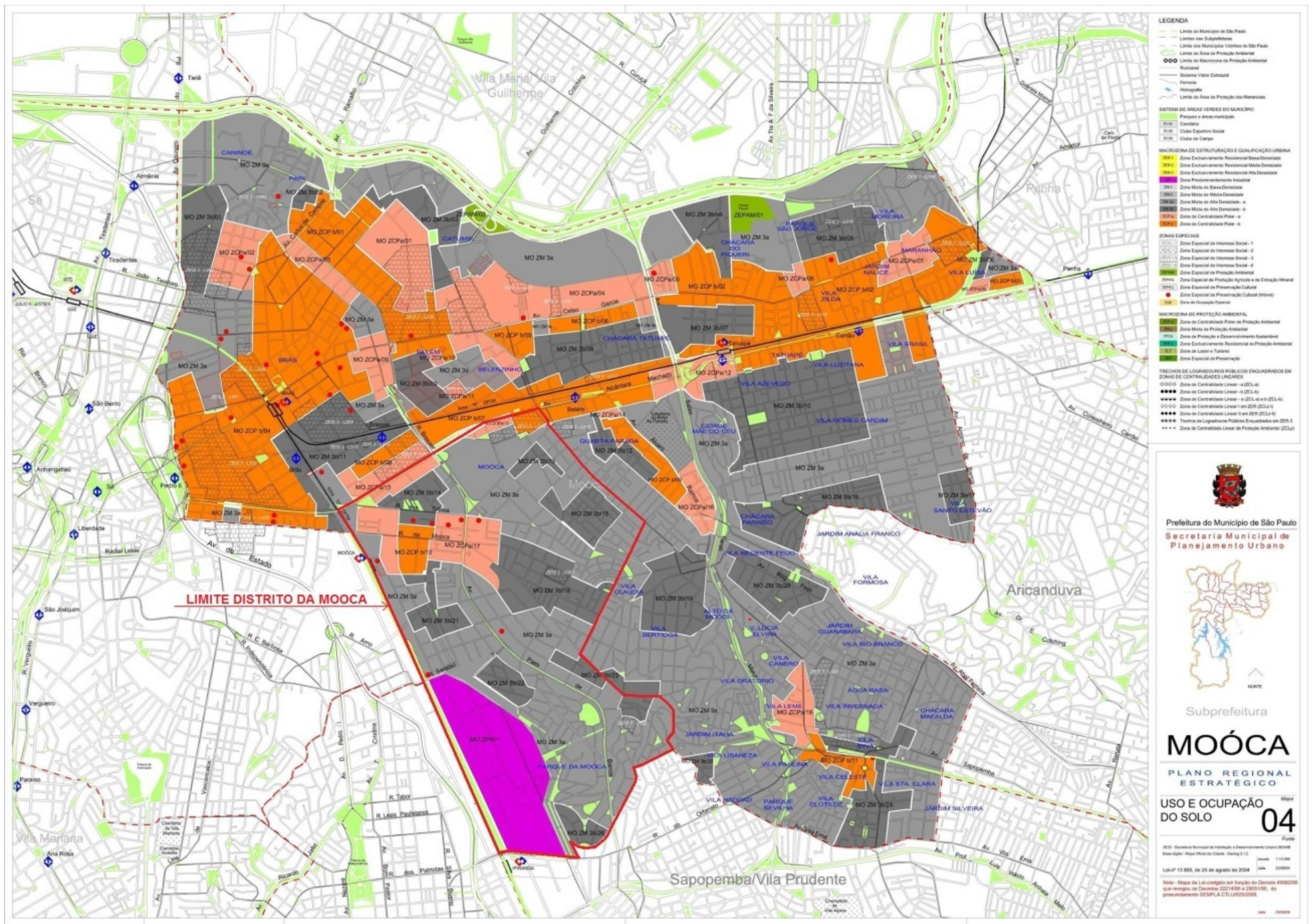

Figura 12 - Mapa de Uso e Ocupação do Solo do Plano Regional Estratégico da Subprefeitura da Mooca com a delimitação do Distrito da Mooca Fonte: Prefeitura do Município de São Paulo 
Com uma área de 7,7 km² e população de 75.724 habitantes, em 2010, segundo dados da Prefeitura do Município de São Paulo, o Distrito da Mooca compõe, juntamente com os Distritos de Água Rasa, Belém, Brás, Pari e Tatuapé, a Subprefeitura da Mooca, que se destaca por constituir um dos núcleos iniciais do processo de industrialização da cidade, onde o mercado imobiliário tem atuado vigorosamente nas últimas décadas, produzindo expressivas alterações na paisagem local.

A Relação de Áreas Contaminadas e Reabilitadas do Estado de São Paulo, publicado pela CETESB em dezembro de 2011, revela a existência de vinte e seis registros na área do Distrito da Mooca, dos quais dezenove são postos de combustível, o que já era esperado, em função da Resolução CONAMA 273/2003, que estabeleceu condições para a localização, construção, instalação, modificação, ampliação e operação destes estabelecimentos.

Ao mesmo tempo, o Relatório de Áreas Contaminadas do Município de São Paulo, de janeiro de 2013, elaborado pela Secretaria do Verde e do Meio Ambiente, indica a ocorrência de vinte e uma áreas, das quais sete fazem parte simultaneamente da listagem da CETESB e quatro estão situadas em endereços próximos às registradas pela CETESB, porém com numeração não coincidente. Há que se ressaltar que a quase totalidade das áreas constantes deste relatório advém de processos de aprovação de projetos de empreendimentos provenientes da Secretaria Municipal de Habitação e, eventualmente, das Subprefeituras, o que aponta para o interesse do mercado imobiliário na região, visto que os imóveis em questão estão localizados nas zonas de uso ZM-3a e ZM-3b (zonas mistas de densidades demográfica e construtiva altas) e ZCP-a (zona de centralidade polar), as quais admitem coeficientes de aproveitamento básico, que variam de 1,0 a 2,0, e máximo, que oscilam de 2,5 a 4,0.

Embora circunscrita a um perímetro relativamente reduzido, o Distrito da Mooca apresenta uma diversidade de situações, que incluem áreas com predomínio de ocupações com padrão horizontal e uso misto, bolsões residenciais de padrão mais elevado convivendo com habitações em condições precárias, novos condomínios residenciais verticais de grandes dimensões, atividade industrial ao longo da orla ferroviária e junto à Avenida Alcântara Machado, além da existência de antigas edificações industriais de interesse histórico. 
O processo de redefinição de usos e de verticalização pode ser percebido com maior intensidade nas zonas de uso misto, embora esta tendência também já possa ser observada em alguns trechos das áreas de ocupação mais industrial, junto à linha férrea, com destaque para a rua Borges de Figueiredo (Fotos 59 a 62) ou a antiga base da Esso, em processo de remediação (Fotos 63 e 64).

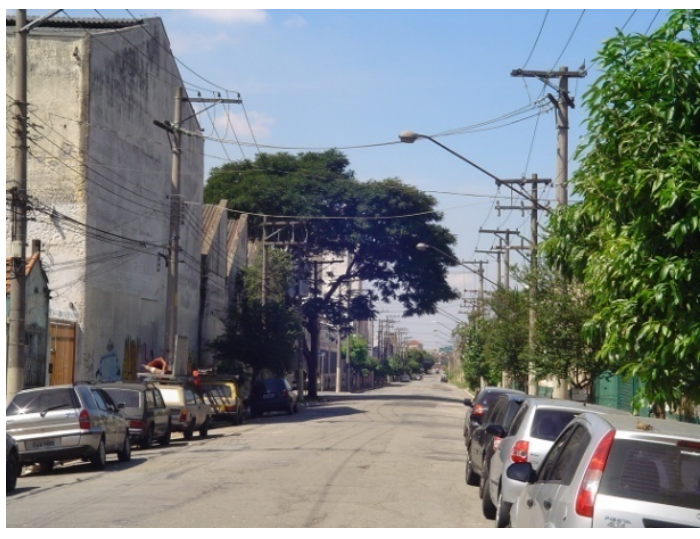

Foto 59 - Vista da rua Borges de Figueiredo, na Mooca, com predominância de galpões

Foto do autor

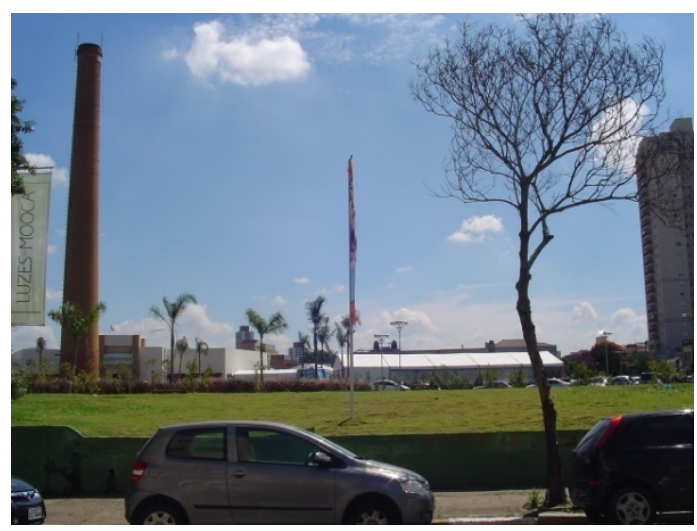

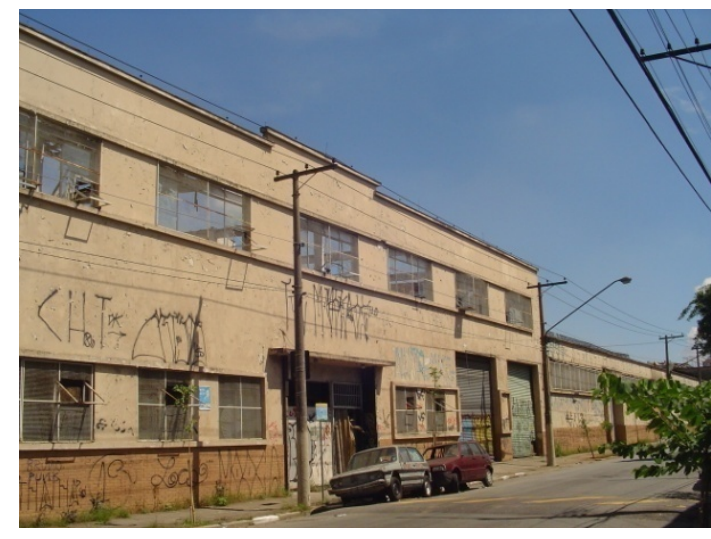

Foto 60 - Vista de galpão abandonado na rua Borges de Figueiredo, na Mooca

Foto do autor



Fotos 61 e 62 - Vistas de antiga área industrial na rua Borges de Figueiredo, Mooca, com chaminé remanescente de demolição e lançamento de empreendimento imobiliário

Fotos do autor
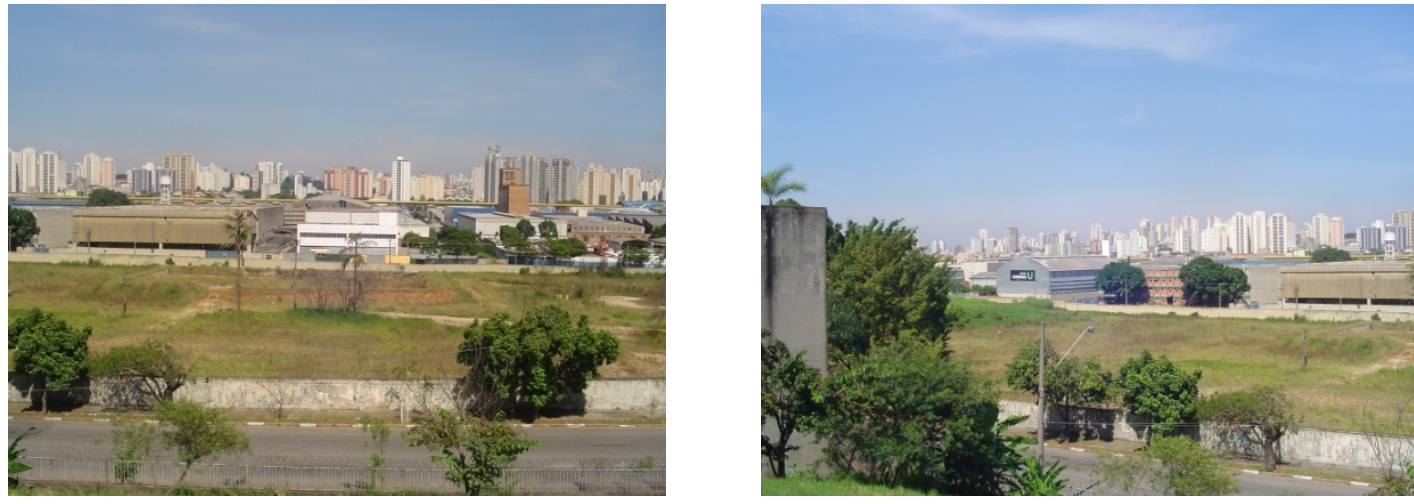

Fotos 63 e 64 - Vistas da antiga base da Esso, na Mooca, em processo de remediação Fotos do autor 
Os grandes condomínios residenciais, constituídos por altíssimas torres de apartamentos implantadas em antigos terrenos industriais de grandes dimensões, tem se tornado o tipo de empreendimento imobiliário predominante nestas áreas, durante os últimos anos (Fotos 65 a 72).

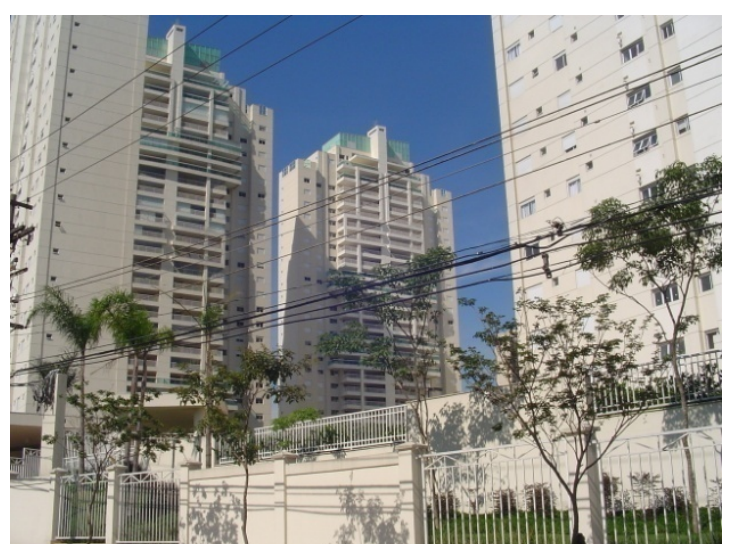

Foto 65 - Grandes condomínios de edifícios residenciais ocupando antigas áreas industriais, Mooca

Foto do autor

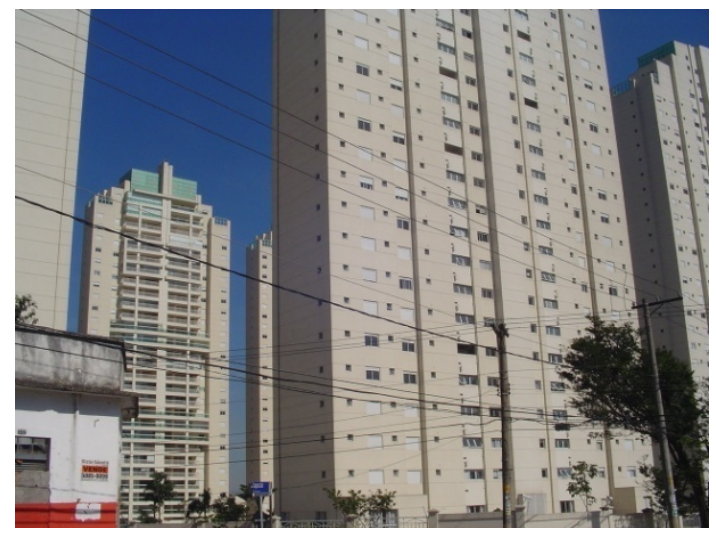

Foto 67 - Vista de condomínio composto de grandes torres residenciais, na rua Sapucaia, Mooca

Foto do autor

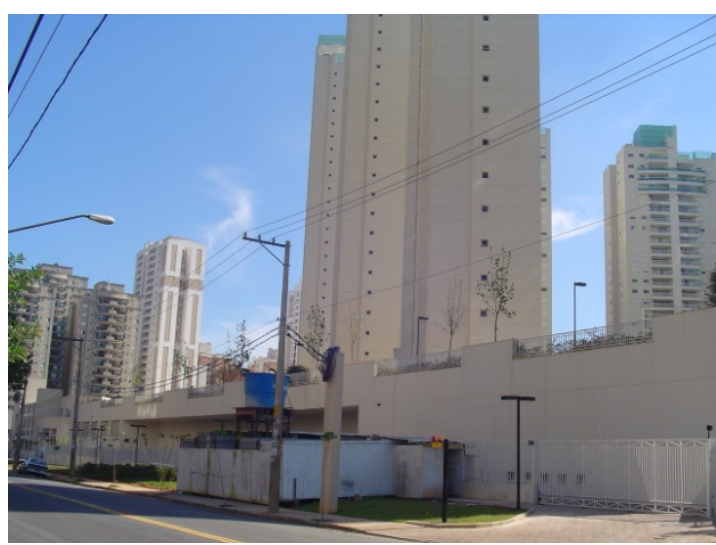

Foto 66 - Muros contínuos cercando os grandes condomínios, criando espaços desertos, Mooca

Foto do autor

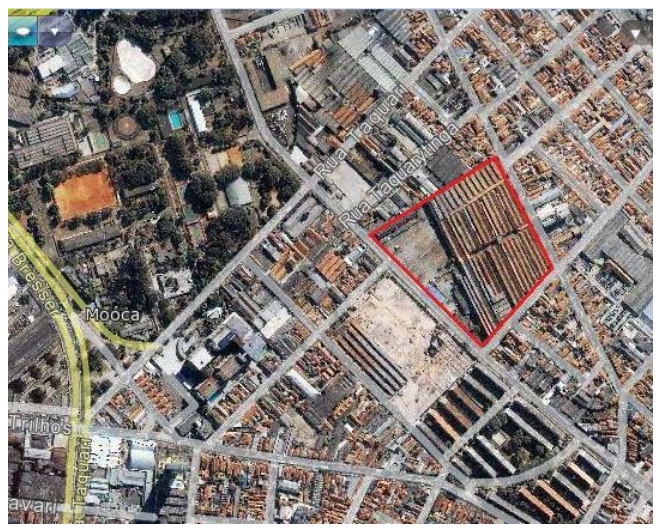

Foto 68 - Vista de foto aérea de 2003, mostrando em vermelho antiga área industrial, atualmente ocupada por condomínio na rua Sapucaia, Mooca

Fonte: Prefeitura Município de São Paulo Secretaria Municipal de Habitação 


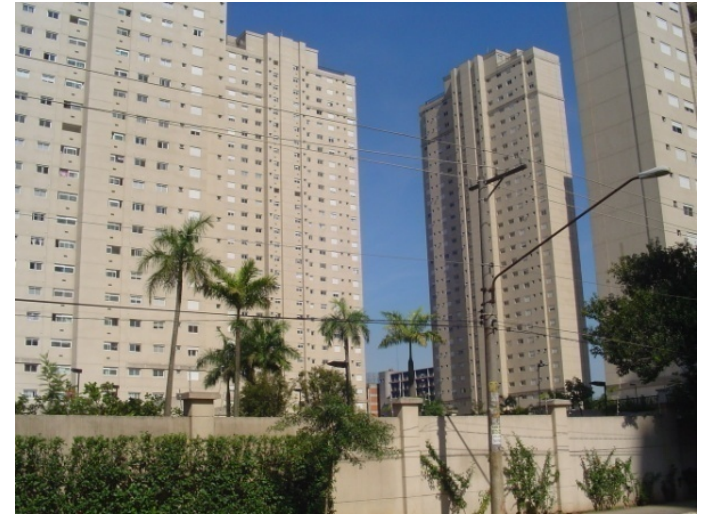

Foto 69 - Vista de condomínio composto de grandes torres residenciais, na avenida Cassandoca, Mooca

Foto do autor

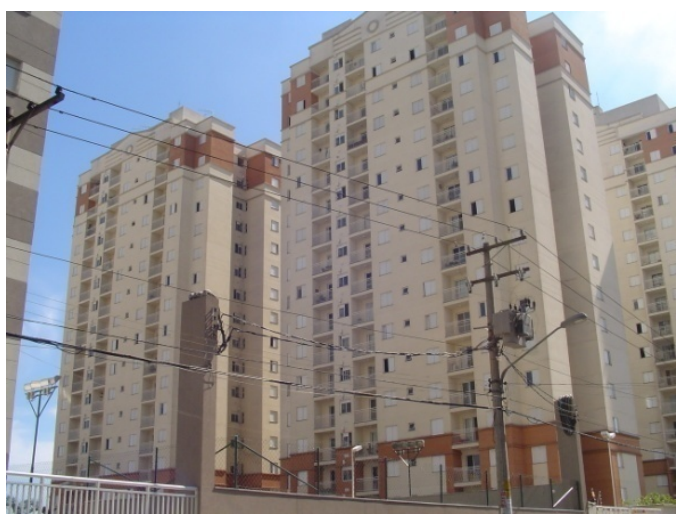

Foto 71 - Vista de condomínio residencial, na rua Taquari, Mooca

Foto do autor

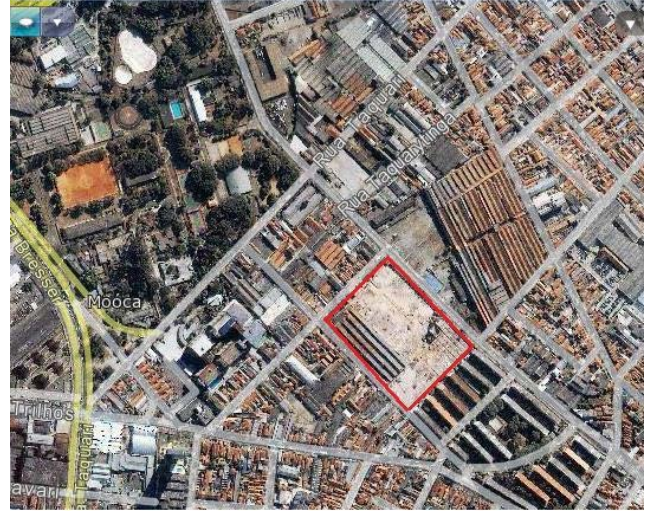

Foto 70 - Vista de foto aérea de 2003, mostrando em vermelho antiga área industrial, atualmente ocupada por condomínio na avenida Cassandoca, Mooca

Fonte: Prefeitura Município de São Paulo Secretaria Municipal de Habitação

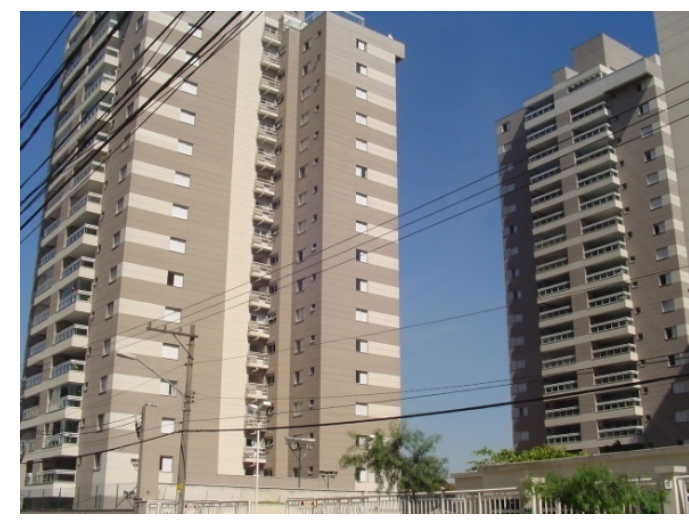

Foto 72 - Vista de condomínio residencial, na rua Taquari, Mooca

Foto do autor

Trechos com uso industrial mais concentrado, como a avenida Henry Ford (Foto 73), ainda mantêm uma atividade intensa, ainda que a inauguração de um shopping center nesta via, no final de 2011, num terreno contaminado, anteriormente ocupado pela fábrica da Ford e objeto de processo de remediação, possa indicar o início de uma transformação também naquela localidade (Foto 74). 


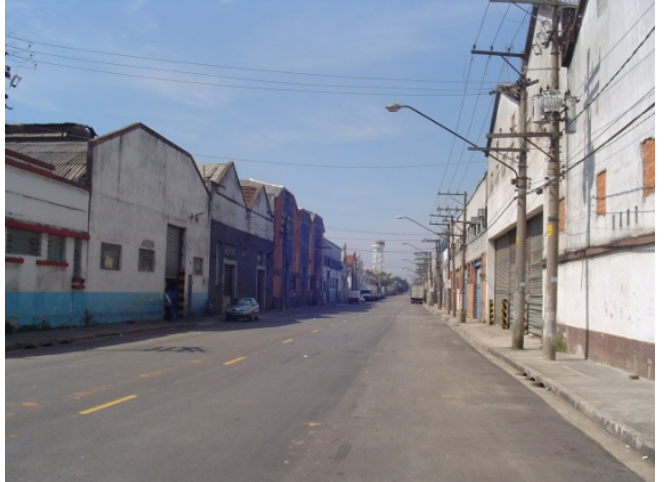

Foto 73 - Vista da avenida Henry Ford, Mooca, mostrando padrão de ocupação por galpões industriais, ainda em atividade

Foto do autor

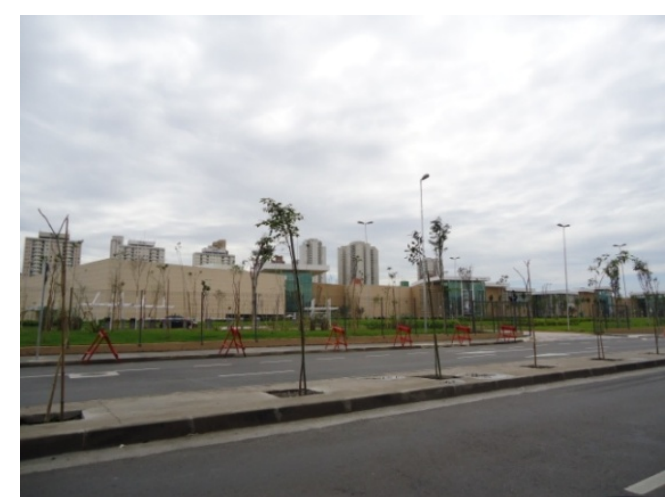

Foto 74 - Vista de shopping center em construção na avenida Henry Ford, Mooca, na antiga área da fábrica da Ford

Foto do autor

Embora não faça parte do Distrito da Mooca, a Avenida Presidente Wilson, situada paralelamente à Avenida Henry Ford e à ferrovia, também abriga fábricas e depósitos ao longo de todo o seu trajeto de aproximadamente sete quilômetros, até a cidade de São Caetano do Sul. Apesar de grande parte das empresas ainda se manterem ativas, já é significativo o número de galpões desativados para alugar ou desocupados com aspecto de abandono, incluindo grandes complexos industriais como a antiga fábrica inativa da Antártica (Foto 75), além de imóveis pontuais ocupados por famílias de sem-teto (Foto 76).

A topografia totalmente plana e a configuração da avenida Presidente Wilson, praticamente em linha reta, realçam a monotonia de uma paisagem praticamente desprovida de vegetação e de pessoas, classificada por Laurentino (2002) como árida e desoladora, que transmite uma sensação de solidão, interrompida apenas nos horários de saída e de almoço dos trabalhadores. Um aspecto ressaltado por esse autor refere-se à presença de escadas e comportas nos acessos aos imóveis, assim como de rampas nas entradas de caminhões, a partir de um determinado ponto da via, em razão da ocorrência das inundações do Tamanduateí, fato que só faz lembrar que aquela área ainda pertence à várzea do rio. 


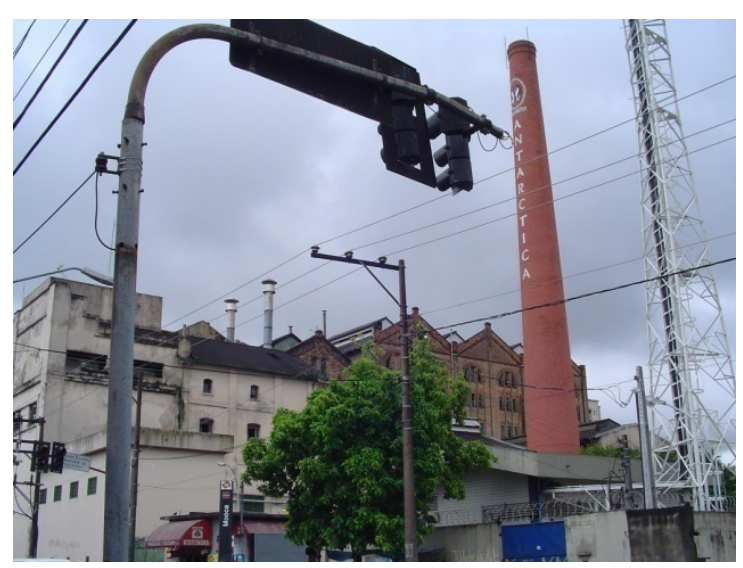

Fig. 75 - Vista da fábrica desativada da Antártica na avenida Presidente Wilson, Mooca

Foto do autor



Fig. 76 - Vista de fábrica desativada na avenida Presidente Wilson, Mooca, ocupada por famílias de sem-teto

Foto do autor

Os espaços industriais desocupados costumam gerar uma percepção negativa, por evocarem sentimentos relacionados ao perigo, à ameaça e ao medo, em virtude do aspecto sombrio das ruas e do estado de abandono e deterioração das edificações e instalações, reforçando o processo de fragmentação do tecido urbano. A este respeito, Laurentino (2002) ainda observa que os espaços industriais, como espaços da produção, são concebidos em termos do tempo mecânico, da repetição dos atos, da previsibilidade, da velocidade e, uma vez desativados, tornam-se praticamente destituídos de referenciais, sobretudo humanos, e assim, embora possam ser tombados pela representatividade das características arquitetônicas e como símbolos de uma época, revelam a aridez de espaços funcionais que, quando desocupados, trazem "uma sensação de vazio e solidão".

Curiosamente os novos usos que se instalam nessas áreas acabam reproduzindo uma situação de certa forma similar, já que os grandes condomínios, cercados por altos e extensos muros, contribuem para manter o isolamento e dificultam a criação de espaços de convívio público, do encontro, do inusitado, o que se reflete na ausência do trânsito de pessoas nas ruas.

Vasques (2009) realiza uma análise dos aspectos atuais dos distritos de Brás, Mooca e Belém em sua tese, além de um extenso levantamento sobre os imóveis industriais na região que sofreram recentes transformações de uso. O seu trabalho reafirma a tendência revelada por outros estudos sobre a perda de população em distritos centrais da cidade, assim como a queda da atividade industrial, identificando várias construções fabris, algumas delas com valor histórico e arquitetônico, que 
foram demolidas e substituídas por edificações com usos diversos do original, ou que foram reutilizadas com novas funções.

A presença marcante da ferrovia, embora fundamental para a implementação da atividade industrial, transformou-se num grande obstáculo à medida que os bairros adjacentes foram se desenvolvendo, dificultando as interligações regionais e a acessibilidade no nível local. Meyer \& Grostein (2010) ressaltam a importância para a metrópole dos terrenos da orla ferroviária, resultante do processo de privatização operacional do sistema ferroviário das três companhias que nele atuavam, de forma desvinculada da propriedade das áreas que pertenciam originalmente à Rede Ferroviária Federal. A relevância da orla ferroviária estaria relacionada ao seu potencial de reverter os efeitos adversos decorrentes da própria inserção da via férrea naquela porção do território da cidade e à possibilidade de virem a se constituir em espaços públicos numa região que carece de tais áreas.

Dessa forma, a diversidade de situações encontradas no interior do perímetro em questão coloca a necessidade da utilização de instrumentos de incentivo à recuperação de áreas contaminadas e de promoção das transformações urbanísticas que atendam às singularidades de cada uma delas, considerando inclusive os diferentes níveis de atrativos que apresentam para o mercado.

Marker (2003) cita o trabalho elaborado por Barczewski et $\mathrm{al}^{3}$, que reconhece a existência de três situações diferentes ao se considerar o financiamento como requisito fundamental para viabilizar a recuperação de terrenos degradados, em particular dos contaminados. A primeira delas engloba as áreas com valor imobiliário tão mais elevado que os custos de recuperação, facilmente comercializáveis com recursos privados, sem a necessidade de financiamento e incentivos externos, enquanto que a segunda compreende as áreas nas quais a recuperação poderia ser estimulada por investimentos públicos ou então por instrumentos legais e gerenciais, e a terceira os terrenos de baixo valor imobiliário, com pouco interesse para o mercado, nos quais a recuperação exige necessariamente a aplicação de recursos públicos.

A outorga onerosa surge como uma opção atrativa, visto que as planilhas divulgadas pela Prefeitura do Município de São Paulo revelam que o Distrito da

\footnotetext{
${ }^{3}$ Barczewski, R.; Crocoll, R.; Mohr, H.; Reutmann, H.I. 2003: Lebensqualität erhanlten - Umsteuern beim Flächenverbrauch - Altlastenspektrum 2, 2003.
} 
Mooca foi o primeiro, juntamente com o Distrito do Jaguaré, a ter os seus estoques de potencial construtivo, tanto residencial como não residencial, esgotados em julho de 2010, embora o último distrito dispusesse de potenciais bem menores em comparação à Mooca. Este fato demonstra o grande interesse do mercado imobiliário pela região e parece indicar que, apesar das grandes dimensões dos terrenos utilizados para a implantação dos empreendimentos, o uso apenas do coeficiente de aproveitamento básico não tem sido suficiente para a viabilização destas construções, havendo a necessidade de se recorrer à outorga onerosa para a utilização do potencial construtivo adicional. Há que se ressaltar que, em função da não realização da revisão do Plano Diretor Estratégico em 2012, conforme previa a Lei $n^{\circ} 13.430 / 2002$, os estoques de potencial construtivo também não foram atualizados, o que impossibilitaria a aprovação de novos empreendimentos que ultrapassem o coeficiente de aproveitamento básico do terreno. Nestas condições, a isenção total ou parcial do pagamento da outorga onerosa, condicionada à remediação de terrenos contaminados, poderia beneficiar um número significativo de edificações. Esta possibilidade, no entanto, dependeria de alterações na legislação em vigor, como mencionado anteriormente.

A urbanização ou reurbanização de áreas que contenham terrenos contaminados em seu perímetro, por intermédio do instrumento da concessão urbanística, apresenta-se como uma alternativa de intervenção urbana mais efetiva, ao abranger porções maiores do território da cidade, permitindo reconfigurações mais profundas do tecido urbano, com base em um plano urbanístico a ser elaborado pela concessionária vencedora do processo licitatório. No caso de áreas contaminadas, este plano deve ser necessariamente subsidiado com informações obtidas a partir de procedimentos investigativos, os quais devem seguir as recomendações técnicas emitidas pelos órgãos ambientais competentes.

Considerando que na concessão urbanística a remuneração da concessionária provém basicamente da alienação ou locação de imóveis e da exploração direta ou indireta de áreas públicas na área de intervenção, a sua aplicação tenderá a ser direcionada às regiões da cidade com maior potencial de valorização, o que, em tese, apontaria a Mooca como uma região bastante atrativa.

A requalificação da orla ferroviária da Mooca já tinha sido aventada pela Administração Pública Municipal, por ocasião da realização dos estudos para os 
projetos para implantação da Operação Urbana Diagonal Sul. Considera-se, no entanto, que a concessão urbanística também seria uma opção a se ponderar para a área.

O consórcio imobiliário, embora não regulamentado, abre a possibilidade de utilizá-lo na remediação de áreas contaminadas, visto que o art. 246 da Lei 13.430/02 admite que o instrumento seja aplicado aos imóveis não abrangidos pelo Plano Diretor Estratégico, quando necessários à realização das intervenções urbanísticas nele relacionados. A sua aplicação, no entanto, estaria limitada à capacidade financeira do poder público de executar as obras e, ainda, de arcar com os custos da remediação.

O uso do direito de preempção fica restrito às áreas definidas pelo Plano Diretor Estratégico em vigor, grafadas com esta finalidade, o que não impede que, numa revisão futura do plano, outras áreas venham a ser incluídas, inclusive aquelas sob processo de investigação da contaminação do solo. No que diz respeito ao Distrito da Mooca, esta alteração deveria ser contemplada na revisão do Plano Regional Estratégico da Subprefeitura da Mooca. De qualquer modo, como todo instrumento que envolve a aquisição de bens imóveis pelo poder público, a sua viabilização fica na dependência da disponibilidade de recursos financeiros. Pode-se dizer que o mesmo problema ocorre com a desapropriação e os fundos municipais específicos, como o FUNDURB e o FEMA, cujo emprego na remediação de áreas contaminadas pode ser dificultado pelo fato de poderem ser destinados a uma série de outras finalidades.

O Fundo Estadual para Prevenção e Remediação de Áreas Contaminadas FEPRAC, concebido e criado com finalidade específica, poderá tornar-se um importante instrumento no gerenciamento da questão, porém, como dito anteriormente, até o presente momento não foi regulamentado pelo Estado.

Embora previstas pelo Plano Diretor Estratégico, para diferentes finalidades, as Áreas de Intervenção Urbana (AIU's) têm sido exclusivamente utilizadas na forma de Operações Urbanas Consorciadas. Mesmo assim, haveria a possibilidade da adoção deste instrumento para a realização de intervenções urbanas por meio da aplicação de instrumentos previstos no Estatuto da Cidade. A implantação de uma AIU pressupõe a elaboração prévia de um Plano Urbanístico Específico - PUE, que deve considerar a questão da contaminação do solo, quando as condições da área 
indicarem tal necessidade. Exceto pelas Operações Urbanas Consorciadas Diagonal Sul e Celso Garcia, não há nenhuma outra AIU prevista pelo Plano Regional Estratégico da Subprefeitura da Mooca, na área do Distrito da Mooca.

A porção oeste do Distrito da Mooca está parcialmente inserida no perímetro da Operação Urbana Diagonal Sul, prevista pelo Plano Diretor Estratégico de 2002.

Em 2011, a Prefeitura do Município de São Paulo propôs o estabelecimento de três novas operações urbanas, Mooca/Vila Carioca, Lapa-Brás e Rio Verde-Jacu, que na realidade são o resultado do rearranjo de outras já constantes do Plano Diretor Estratégico, a Diagonal Norte, Água Branca, Centro e Diagonal Sul, fato que gera controvérsia, uma vez que o Estatuto da Cidade exige que as áreas das operações urbanas consorciadas estejam delimitadas nos respectivos planos diretores municipais. Além disso, a fixação de novas delimitações, distintas daquelas existentes no Plano Diretor Estratégico, certamente acarretará consequências e efeitos diversos sobre a estrutura urbana, o que permite interpretá-las como novas operações urbanas, fato contestado pela Prefeitura.

Nesta nova configuração, o trecho do Distrito da Mooca, já mencionado, passaria a integrar a Operação Urbana Consorciada Mooca/Vila Carioca (Fig 13). A proposta de intervenção apresentada no termo de referência do edital para contratação de estudos e projetos da referida intervenção urbana pressupõe a divisão da área em subperímetros, compostos por setores, nos quais se prevê a alteração dos padrões de ocupação do solo, por meio da utilização de instrumentos de incentivo para a indução da atividade imobiliária, como a concessão onerosa do direito de construir, a modificação de usos e de parâmetros urbanísticos, de acordo com diretrizes pré-estabelecidas.

A Operação Urbana Consorciada Mooca/Vila Carioca está dividida da seguinte forma:

- Subperímetro 1, composto pelos setores Cambuci e Mooca, caracteriza-se pela presença de antigas áreas de uso misto e de trechos com atividade industrial mais intensa, notadamente nas avenidas Presidente Wilson e Henry Ford, passando por processo de grande esvaziamento populacional e da atividade econômica;

- Subperímetro 2, composto pelos setores Ipiranga e Parque da Mooca, abriga áreas de uso misto com predominância do uso residencial e áreas de interesse histórico no 
setor Ipiranga, bem como porções do território que apresentam intensificação da atividade imobiliária e outras nas quais se verifica o declínio industrial;

- Subperímetro 3, composto pelos setores Vila Carioca e Vila Prudente, sofre a influência do tráfego de passagem e de cargas decorrente das avenidas do Estado, Anhaia Mello e das Juntas Provisórias que, juntamente com a ferrovia, reforçam a fragmentação do seu território, embora seja dotado de boa infraestrutura de transporte coletivo.

O Distrito da Mooca abrange parcialmente áreas pertencentes ao setor Mooca, no Subperímetro 1, e ao setor Parque da Mooca, no Subperímetro 2.

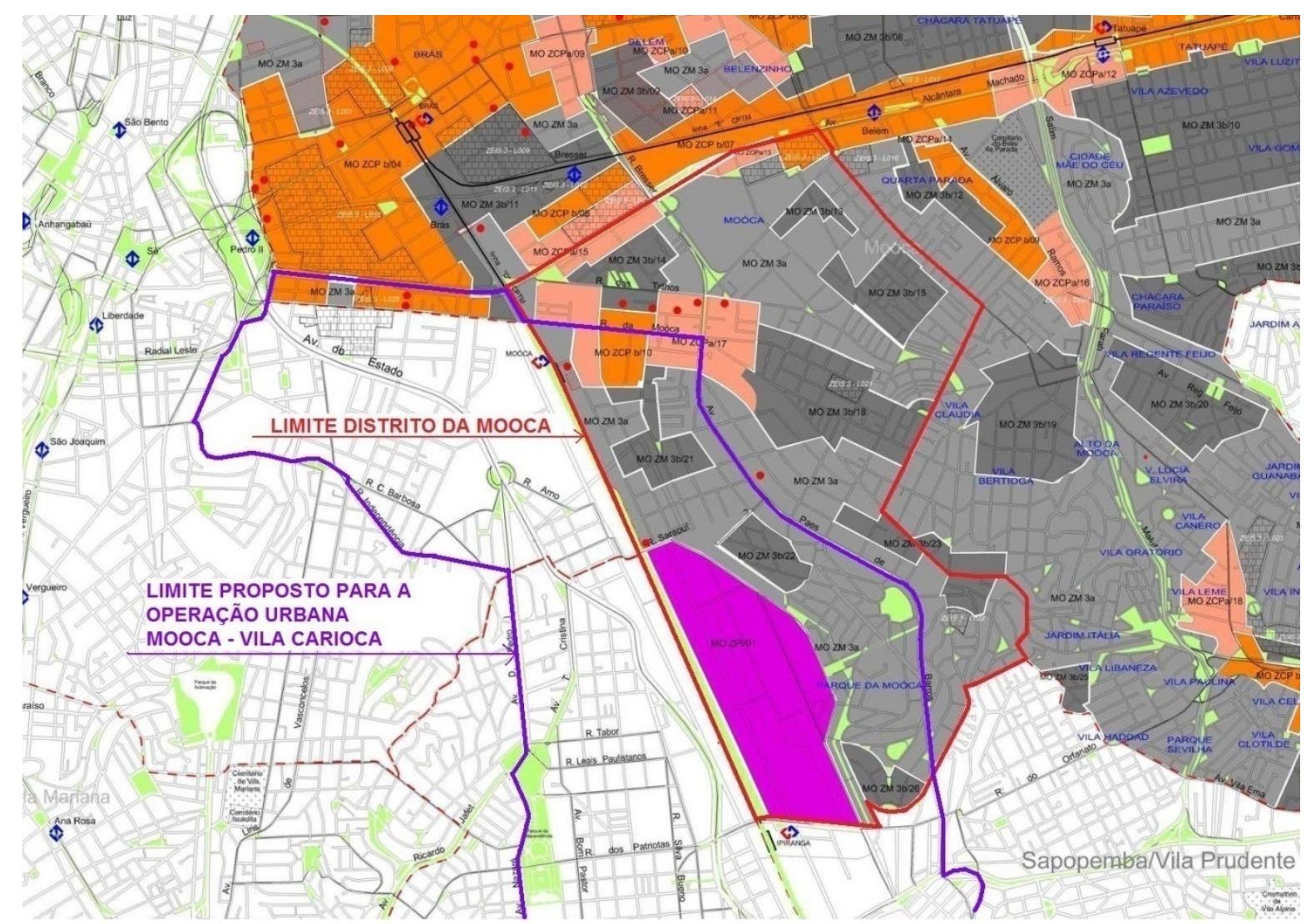

Fig. 13 - Distrito da Mooca e Operação Urbana Mooca - Vila Carioca Fonte: Prefeitura do Município de São Paulo

No que diz respeito às áreas contaminadas, o termo de referência estabelece como um dos objetivos da Operação Urbana "promover a instalação de novos usos compatíveis nas áreas potencialmente contaminadas, possibilitando sua reinserção funcional no ambiente urbano de forma sustentável, segura e integrada aos demais objetivos elencados". Determina, ainda, que o Estudo de Avaliação Econômica deve compreender, entre outros aspectos, "ensaios e avaliação dos impactos da utilização 
de incentivos, instrumentos e estratégias urbanísticas nas receitas da Operação Urbana, relativos à: implantação de melhoramentos públicos; indução de construção de habitações de interesse social e de mercado popular; construção de equipamentos públicos; recuperação de solos contaminados".

Entre os temas a serem abordados pelo estudo do meio físico no Estudo de Impacto Ambiental está o das áreas contaminadas, do qual deverão constar:

"- levantamento das áreas afetadas por desapropriação total ou parcial e que sofrerão interferência direta das obras integrantes da Operação Urbana Consorciada;

- levantamento de todas as atividades atuais e pretéritas desenvolvidas nas áreas com desapropriação total ou parcial inseridas na Operação Urbana Consorciada, que sofrerão interferência direta das obras;

- relação de todas as áreas afetadas com desapropriação total ou parcial que sofrerão interferência direta das obras e que possuem atividades com potencial de contaminação de acordo com a lista de atividades industriais e comerciais do Instituto Brasileiro de Geografia e Estatística - IBGE, potencialmente contaminadoras do solo e das águas subterrâneas, contida no Manual de Gerenciamento de Áreas Contaminadas da CETESB;

- levantamento de todas as áreas públicas que sofrerão interferência direta das obras, que possuem atividades com potencial de contaminação de acordo com a lista de atividades industriais e comerciais do IBGE, potencialmente contaminadoras do solo e das águas subterrâneas, contida no Manual de Gerenciamento de Áreas Contaminadas da CETESB;

- identificação de todas as áreas particulares levantadas por meio de Setor, Quadra e Lote;

- identificação de todas as áreas contaminadas ou suspeitas de contaminação constantes do cadastro de áreas contaminadas da CETESB, inscritas no perímetro da Operação Urbana Consorciada".

De maneira apropriada, os levantamentos acima mencionados dão um enfoque significativo à investigação das áreas com potencial de contaminação, cujas informações deverão subsidiar a obtenção de um panorama ambiental mais preciso 
da região e a definição de instrumentos urbanísticos e ambientais apropriados a serem aplicados na área. Deve-se observar que a Relação de Áreas Contaminadas divulgada pela CETESB não contém informações a respeito de locais com suspeita de contaminação e que, no nível municipal, o GTAC também passou a publicar o Relatório de Áreas Contaminadas, cujas áreas identificadas nem sempre coincidem com aquelas relacionadas pela CETESB.

Como ressaltado anteriormente, a exigência da elaboração de um Plano da Operação Urbana que contivesse um projeto urbanístico, conforme previsto pelo Projeto de Lei no 671/2007, poderia contribuir para uma reconfiguração espacial mais ordenada, facilitando as ações visando à investigação e remediação de áreas contaminadas.

Ainda assim, considera-se fundamental para o processo de requalificação do espaço urbano, principalmente das antigas áreas com padrão de ocupação industrial, a utilização de instrumentos de intervenção que permitam o reparcelamento do solo, a reconfiguração viária e a criação de novas áreas públicas, em especial de espaços de convívio social e de áreas verdes.

O estudo de Meyer \& Grostein (2010) sobre o Vetor Leste do Centro identificou como elementos estruturadores mais evidentes daquela porção do território da cidade o rio Tamanduateí, a ferrovia e o sistema viário intermunicipal, que se estendem em escala metropolitana, em direção aos municípios de São Caetano do Sul e Santo André, definindo o que denominam Eixo Sudeste da Metrópole. Além destes elementos, a existência de outros eixos viários metropolitanos que cortam o Vetor Leste do Centro produz um território fragmentado com áreas pouco acessíveis, revelando a necessidade de projetos que produzam as conexões necessárias à integração urbana. Sob este ponto de vista, a articulação de diferentes escalas estaria estreitamente relacionada à presença de elementos que se estruturam em redes, inclusive em nível metropolitano, em especial aquelas relacionadas à mobilidade e aos transportes públicos.

As autoras destacam o caráter decisivo da dimensão ambiental na reorganização urbana da área de estudo e ressaltam que a elaboração de qualquer projeto urbano ou urbanístico deve ser precedida de uma avaliação criteriosa das condições existentes da infraestrutura, com ênfase no abastecimento de água e de drenagem, bem como do nível de comprometimento dos terrenos industriais, em 
função da contaminação do solo, considerando necessariamente o caráter sistêmico inerente a estas questões.

A possibilidade de implementação da Operação Urbana Consorciada Mooca Vila Carioca traz a perspectiva de profundas transformações nas formas de uso e no nível de adensamento da região, o que não garante, em razão dos motivos já expostos, uma efetiva qualidade urbana e ambiental. Na realidade, as operações urbanas acabam beneficiando determinadas porções do território da cidade de grande interesse para o mercado imobiliário, invariavelmente criando condições para o incremento do potencial construtivo nesses perímetros e utilizando os recursos arrecadados para privilegiar a implantação de grandes obras viárias que priorizam o transporte individual, em detrimento do investimento em sistemas de transporte público.

Não obstante, projetos urbanos de abrangência local acabam se ressentindo da ausência de estratégias efetivas de intervenção urbana em escala metropolitana. A este propósito, Meyer \& Grostein (2010) enfatizam a distinção entre o planejamento municipal, que se baseia num complexo arcabouço legal que regula o desenvolvimento urbano, e o plano e a agenda de projetos destinados ao desenvolvimento metropolitano, que devem se fundamentar na articulação de projetos de infraestrutura e de equipamentos e serviços com escala de atendimento no âmbito metropolitano. Para tanto, afirmam que a estratégia que tem se mostrado mais eficiente em outros contextos tem sido a de associar planejamento a projetos setoriais específicos de nível metropolitano, os quais perderiam o caráter de obras isoladas.

Assim como a região da Mooca e Ipiranga, outras áreas da cidade de São Paulo, como Santo Amaro, Vila Leopoldina e Lapa, e de outros municípios da Região Metropolitana, como Guarulhos, São Bernardo do Campo, Santo André e São Caetano do Sul, também vivem um processo de transformação das características urbanas em antigas zonas industriais, tendo como os indicativos mais significativos destas mudanças o número de novos lançamentos imobiliários observado nos últimos anos e a introdução de novos usos do solo.

Como visto anteriormente, os exemplos internacionais apontam que o tratamento de áreas afetadas pela contaminação do solo e das águas subterrâneas mostra-se mais adequado, quando inserido no âmbito de projetos urbanísticos, nos 
quais é possível utilizar-se dos instrumentos previstos pela legislação, de acordo com as especificidades presentes em cada uma delas. Entende-se, porém, que as intervenções não deveriam se limitar apenas ao aspecto da contaminação, mas também da criação e requalificação dos espaços públicos e da reconfiguração do padrão de parcelamento do solo existente nessas localidades, que se caracteriza pela presença de lotes de grandes dimensões oriundos do seu antigo uso industrial. 


\section{Conclusão}

As ações humanas sobre o meio natural reforçam o sentido contraditório da relação entre homem e natureza, que se evidenciam de forma concreta na organização espacial da cidade e se traduz naquilo que se percebe como paisagem.

A emergência da noção de sustentabilidade tem suscitado o surgimento de uma proliferação de concepções diversas, e por vezes divergentes, a respeito do termo, de acordo com a conveniência de quem o utiliza. Há que se reconhecer, no entanto, que o crescente nível de degradação das condições ambientais e o esgotamento dos recursos naturais constituem fatos reais, os quais poderão ter implicações não só para a sobrevivência da espécie humana no planeta, mas também do próprio sistema produtivo vigente. Ainda assim, mesmo diante da inegável incompatibilidade entre a lógica que move o modo de produção dominante e o uso sustentável dos recursos naturais, não há como desconsiderar a relevância das ações que buscam estabelecer novas formas de relações socioeconômicas regidas pela racionalidade ambiental.

Em São Paulo, a coexistência de áreas privilegiadas e de áreas de extrema pobreza, carentes dos serviços mais básicos, configura uma condição de grande segregação social, econômica e espacial na cidade. Do ponto de vista ambiental e urbanístico, esta situação foi se agravando ao longo do tempo e resultou numa proliferação de ocupações irregulares, à margem da legislação, quase sempre localizadas em áreas ambientalmente frágeis, que se tornam o único destino possível para os que não podem arcar com custos de moradia nas regiões mais centrais e privilegiadas da cidade.

A abordagem fragmentada das questões ambientais, desvinculadas do contexto socioeconômico no qual estão inseridas, enseja o surgimento de visões parciais a respeito de um mesmo problema, dificultando a percepção das relações que se estabelecem entre os diversos aspectos envolvidos na sua gênese.

Esta prática fica claramente evidenciada na atuação do poder público, quando se constata que as ações isoladas e desconexas de cada órgão ou instituição são a regra geral. $O$ tratamento das áreas contaminadas não é exceção e torna-se preocupante, na medida em que as antigas áreas industriais da cidade vêm sendo 
ocupadas pelo mercado imobiliário e se tornando alvo de planos de desenvolvimento urbano promovidos pelo poder público.

A descaracterização do uso industrial em diversas áreas da cidade, em especial daquelas que tiveram origem no processo inicial de industrialização da cidade, tem produzido alterações nas formas de uso e ocupação do solo, fato reconhecido pelo Plano Diretor Estratégico e pelos Planos Regionais, que promoveram mudanças no zoneamento, transformando-as em Zonas Mistas (ZM) na legislação atual, algumas delas de média e alta densidade. Muitas delas coincidem com o perímetro das Zonas de Uso Predominantemente Industrial (ZUPI), definidas pela legislação estadual da década de 70.

A crescente procura de terrenos em antigas áreas industriais pelo mercado imobiliário tem consequências relevantes do ponto de vista ambiental e urbanístico, além de produzir significativos impactos sobre a paisagem.

A implantação de novos empreendimentos em áreas com histórico anterior de ocupação por uso industrial requer atenção redobrada, principalmente quando o tipo de atividade exercida no passado apresenta potencial para a contaminação do solo e das águas subterrâneas.

Por outro lado, a manutenção do padrão fundiário existente, representado por terrenos de dimensões grandiosas, utilizados para a implantação de condomínios residenciais de alto padrão, tem contribuído para reforçar uma forma recorrente de ocupação do solo nessas regiões, que se caracteriza pela construção de conjuntos de grandes torres cercados por altos muros, em algumas situações ocupando quadras inteiras. Os espaços públicos resultantes deste tipo de configuração destacam-se pela ausência do elemento humano, o que geralmente produz um sentimento de isolamento e insegurança a quem circula por essas áreas.

As paisagens pós-industriais que se moldam na cidade de São Paulo podem ser entendidas como o produto de uma dupla movimentação, a primeira delas gerada por novas formas de organização da produção, que determinam novas divisões territoriais do trabalho, e culminam no processo de transformação de antigos usos, em função da obsolescência dos objetos que compõem a paisagem. A segunda diz respeito ao tratamento desigual que se dá a determinadas partes do 
território, por meio da canalização dos recursos públicos para provê-las de infraestrutura, num movimento de segregação espacial da cidade.

Assim, o que se observa a partir desse processo é uma crescente tendência à construção de espaços isolados sobre porções fragmentadas do território da cidade, que não só introduz a preocupação com o problema da contaminação do solo, mas também com a configuração de lugares não qualificados, não apropriados pela população e desprovidos da ideia de cotidiano.

Entretanto, num ambiente tão modificado como o urbano, é preciso reconhecer que os valores naturais originais já não estão mais presentes, embora os processos naturais ainda continuem presentes e atuantes. Assim, as ações que tendem a reconstituir a natureza como ela era soam como algo deslocado, e atribuir novos valores aos objetos que compõem a paisagem da cidade pode significar a possibilidade de promover a sua requalificação e a reintrodução do cotidiano no espaço urbano, como forma de restabelecer as relações sociais que dão sentido ao lugar.

Muitos arquitetos e urbanistas manifestam-se sobre a necessidade de recuperação e reocupação de áreas urbanas degradadas, entre as quais as antigas áreas industriais e as orlas ferroviárias, por se tratarem de regiões centrais dotadas de infraestrutura e transporte público. Em ambos os casos há grande possibilidade da ocorrência de contaminação do solo e das águas subterrâneas e, certamente por absoluto desconhecimento do problema, a quase totalidade dos profissionais sequer considera este aspecto na formulação de propostas ou de projetos para tais áreas. Assim, torna-se urgente que o tema passe a ter a devida divulgação, para que não se corra o risco de se implantar projetos considerados "sustentáveis", com certificação internacional, sobre áreas contaminadas, ratificando-se a banalização do termo sustentabilidade e a sua apropriação "distorcida" pelo mercado.

As políticas públicas na área do desenvolvimento urbano e os planos e projetos a elas atrelados, em antigas áreas industriais, que pretendam se qualificar como minimamente sustentáveis, deveriam ao menos considerar a questão da contaminação do solo e suas implicações nos campos social, econômico, ambiental e urbanístico. 
Tendo em vista a competência legal do município para tratar dos assuntos relativos ao uso e à ocupação do solo, considera-se fundamental o papel do poder público local na reabilitação de áreas contaminadas, especialmente em regiões que passam por processos de mudança de usos. Neste aspecto, a utilização de instrumentos de incentivo à reutilização e requalificação urbana adquire uma função importante, ao favorecer o aproveitamento de terrenos com restrições ambientais, mediante o estabelecimento de regras pré-determinadas. Entretanto, esta possibilidade ainda esbarra na falta de regulamentação de vários dos instrumentos, além dos problemas de caráter legal e institucional e da falta de fundos específicos.

Ainda assim, diante das condições institucionais e legais existentes, tende-se a concluir que a transposição de modelos e instrumentos para a revitalização de áreas contaminadas, tais como as existentes na Alemanha ou nos Estados Unidos, é praticamente inviável. A atuação totalmente fragmentada dos órgãos da administração, mesmo nas tarefas mais rotineiras do serviço público, as restrições de ordem legal, particularmente no que tange ao aspecto da responsabilização, além da forma como o poder público encara, na prática, as questões ambientais, tornamse verdadeiros obstáculos à aplicação de mecanismos que exigem procedimentos consolidados, ações setoriais integradas e segurança jurídica, entre outros fatores. Certamente estas dificuldades também estarão presentes, mesmo na utilização dos instrumentos previstos pela legislação municipal.

A recuperação ambiental e urbanística de áreas contaminadas, no entanto, não se restringe somente à remediação da contaminação, mas deve estar atrelada à requalificação do espaço urbano, com particular atenção às áreas públicas, e à possibilidade de reconfiguração do próprio traçado urbano. Neste contexto passa a adquirir especial relevância a questão da abordagem preventiva, que no entendimento de Sánchez (2001) busca eliminar os passivos ambientais no momento em que um empreendimento industrial é desativado, de modo a evitar que problemas como a contaminação do solo e dos aquíferos voltem a se repetir, o que pressupõe a preparação e implementação de um plano de desativação, antes mesmo que ocorra o encerramento da atividade.

Os estudos ora realizados acerca dos fatores que envolvem o gerenciamento de áreas contaminadas, das experiências internacionais e da atuação do poder público sobre a questão reafirmam a hipótese principal deste trabalho, na medida 
em que se constata que as condições essenciais e os requisitos básicos para que ela se efetive ou se torne minimamente factível, no atual contexto institucional, legal e social do país, mais especificamente da cidade de São Paulo, ainda são bastante incipientes, apesar de alguns avanços pontuais observados nos últimos anos.

A alegada falta de recursos financeiros para atender às necessidades da população, tão enfatizada pelos governantes, em todos os níveis de poder, vem elevando progressivamente a procura por soluções nas parcerias público-privadas. Não obstante, é imprescindível que as ações que visam ao tratamento e à reabilitação de áreas contaminadas, ou mesmo à ordenação do espaço urbano, não acabem privilegiando apenas as dimensões administrativa e econômica da questão, como alertam Knapp \& Hollander (2012). De qualquer forma, entende-se que a utilização adequada de instrumentos e mecanismos para a reabilitação de áreas contaminadas corroboram o posicionamento de Montibeller no que diz respeito à importância das ações que objetivam alcançar "processos de transformação das condições socioeconômicas com uma melhor relação do homem com a natureza".

Finalmente, a partir do momento em que a presença de substâncias perigosas ou a possibilidade de sua existência passam a afetar a reúso dessas áreas ou mesmo a utilização de propriedades em seu entorno e a saúde da população, torna-se legítimo que a comunidade atingida por tais circunstâncias participe das decisões a respeito do processo de sua recuperação ambiental e urbana. Não há como desconsiderar casos como o da Vila Carioca, em São Paulo, com famílias que ainda sofrem com as consequências da contaminação do solo e das águas subterrâneas, causada pela atividade industrial, ou do condomínio Barão de Mauá, construído sobre um aterro de resíduos industriais, além de vários outros que vêm se tornando de conhecimento público ao longo do tempo. Entretanto, a participação da população nesse processo depende da existência de instâncias oficiais para a manifestação da comunidade e dos demais atores envolvidos, cujo conteúdo seja efetivamente incorporado nas ações a serem colocadas em prática, como também de um grau mínimo de organização social que possibilite o surgimento de grupos estruturados em torno de objetivos comuns, independentemente da anuência oficial. Este, porém, é um desafio a ser enfrentado, pois pressupõe a existência de um nível de cultura política que ainda está para ser 
construído e que, mesmo em países com tradição de participação, não ocorre de maneira pacífica. 


\section{Referências bibliográficas}

ACSELRAD, Henri, HERCULANO, Selene \& PÁDUA, José Augusto (orgs). Justiça ambiental e cidadania. Rio de Janeiro: Relume Dumará: Fundação Ford, 2004.

ALVES, Maristela Pimentel. A recuperação de rios degradados e sua reinserção na paisagem urbana: a experiência do rio Emscher na Alemanha. Dissertação de Mestrado. Faculdade de Arquitetura e Urbanismo da Universidade de São Paulo. São Paulo, 2003.

BARTALINI, Vladimir. Os córregos ocultos e a rede de espaços públicos urbanos. Paisagem e ambiente: ensaios. São Paulo: FAUUSP, n. 16, 2004.

BIZELLI, José Luís. Estado, democracia e gestão da inovação. In BIZELLI, José Luís \& FERREIRA, Darlene Aparecida de Oliveira (orgs.), Governança pública e novos arranjos de gestão. Piracicaba: Jacintha Editores, 2009.

BRASIL. Lei $\mathrm{n}^{0}$ 12.305, de 2 de agosto de 2010. Institui a Política Nacional de Resíduos Sólidos; altera a Lei no 9.605, de 12 de fevereiro de 1998; e dá outras providências. Diário Oficial da República Federativa do Brasil, Poder Executivo, Brasília, DF, 3 de agosto de 2010. Seção 1.

BRASIL. Resolução CONAMA n 420/09, de 28 de dezembro de 2009. Dispõe sobre critérios e valores orientadores de qualidade do solo quanto à presença de substâncias químicas e estabelece diretrizes para o gerenciamento ambiental de áreas contaminadas por essas substâncias em decorrência de atividades antrópicas. Diário Oficial da República Federativa do Brasil, Poder Executivo, Brasília, DF, 30 de dezembro de 2009. Seção 1, pp.81-84.

BRASIL. Resolução CONAMA no 273, 29 de novembro de 2000. Estabelece diretrizes para o licenciamento ambiental de postos de combustíveis e serviços e dispõe sobre a prevenção e controle da poluição. Diário Oficial da República Federativa do Brasil, Poder Executivo, Brasília, DF, 8 de dezembro de 2001. Seção 1, pp.20-23.

BRASIL tem assessores demais, diz estudo. Folha de São Paulo, São Paulo, 16 jan. 2011. Disponível em: .< http://acervo.folha.com.br/fsp/2011/01/16/2/>. Acesso em: 16 jan. 2011. 
CANON, Jonathan Z. "Adaptive management in Superfund: thinking like a contaminated site". In: MACEY, Gregg P. \& CANON, Jonathan Z. (editors), Reclaiming the land: rethinking Superfund institutions, methods and practices. New York: Springer Science, 2010.

CARMAN, Eric. "From laboratory to landscape: a case history and possible future direction for phyto-enhanced soil bioremediation". In: KIRKWOOD, Niall (editor), Manufactured sites: rethinking the post-industrial landscape. New York: Taylor \& Francis, 2001.

CASTRO, C. M. de \& TAKAHASHI, F. USP Leste é multada por ter gás em seu subsolo. Folha de São Paulo, São Paulo, 17 nov. 2011. Cotidiano, p. C8.

CETESB, GTZ. Manual de Gerenciamento de Áreas Contaminadas. São Paulo, 2001.

CETESB ameaça interditar shopping Center Norte. Folha de São Paulo, São Paulo, 17 set. 2011. Disponível em: < http://acervo.folha.com.br/fsp/2011/09/17/15/>. Acesso em: 17 set. 2011.

COMISSÃO MUNDIAL SOBRE MEIO AMBIENTE E DESENVOLVIMENTO. NosSo Futuro Comum. Rio de Janeiro: FVG, 1991.

COSTA, Heloísa Soares de Moura. "Desenvolvimento urbano sustentável: uma contradição de termos?". In: Revista Brasileira de Estudos Urbanos e Regionais, no 2, nov./1999.

COSTA, Heloísa Soares de Moura. "Meio ambiente e desenvolvimento - um convite à leitura". In: HISSA, Cássio Eduardo Viana (org.), Saberes ambientais: desafios para o conhecimento disciplinar. Belo Horizonte: Editora UFMG, 2008.

DEAN, Warren. A industrialização de São Paulo (1880-1945); trad. Octavio Mendes Cajado. São Paulo: Difel / Difusão Editorial S.A., s/d.

DRUCKER, Peter Ferdinand. Sociedade pós-capitalista; trad. Nivaldo Montingelli Jr. São Paulo: Pioneira, 1993.

DUARTE, Rodrigo A. de Paiva. Marx e a natureza em O Capital. São Paulo: Loyola, 1995. 
DUKES, Franklin E. "Rethinking community involvement for Superfund site reuse: the case for consensus-building in adaptive management". In: MACEY, Gregg P. \& CANON, Jonathan Z. (editors), Reclaiming the land: rethinking Superfund institutions, methods and practices. New York: Springer Science, 2010.

FLORIANI, Dimas. "Marcos conceituais para o desenvolvimento da interdisciplinaridade". In PHILIPPI Jr., Arlindo; TUCCI, Carlos E. Morelli; HOGAN, Daniel Joseph \& NAVEGANTES, Raul (eds). Interdisciplinaridade em ciências ambientais. São Paulo: Signus Editora, 2000.

FUKS, Mário. Conflitos ambientais no Rio de Janeiro: ação e debate nas arenas públicas. Rio de janeiro: Editora UFRJ, 2001.

GERAQUE, E. Morador habita área contaminada em SP sem saber. Folha de São Paulo, São Paulo, 09 ago. 2010. Cotidiano, p. C4.

GERAQUE, E. Morador de área contaminada busca reparação na Justiça. Folha de São Paulo, São Paulo, 23 jul. 2012. Cotidiano, p. C6.

GERAQUE, E. Justiça manda indenizar comprador de imóvel em terreno contaminado. Folha de São Paulo, São Paulo, 21 ago. 2012. Cotidiano, p. C4.

GERAQUE, E. Cetesb ameaça interditar shopping Center Norte. Folha de São Paulo, São Paulo, 17 set. 2011. Cotidiano, p. C1.

GOVERNO do Estado de São Paulo quer construir piscinão em área contaminada. Portal UOL, São Paulo, 11 jan. 2013. Disponível em: $<$ http://noticias.uol.com.br/busca?q=piscin\%C3\%A3o+vila+prudente\#q=piscin $\%$ C3\% A3o\%20vila\%20prudente> Acesso em: 11 jan. 2013.

GOVERNO paulista expande USP Leste em área contaminada. Folha de São Paulo, São Paulo, 17 abr. 2012. Disponível em: < http://acervo.folha.com.br/fsp/2012/04/17/15/>. Acesso em: 17 abr. 2012.

GRIMSKI, Detlef. Brownfield Redevelopment in Germany and Europe. In II Seminário Internacional sobre Remediação In-situ de Sites Contaminados. São Paulo, 2003.

HISSA, Cássio Eduardo Viana. "Saberes ambientais: a prevalência da abertura". In HISSA, Cássio Eduardo Viana (org.), Saberes ambientais: desafios para o conhecimento disciplinar. Belo Horizonte: Editora UFMG, 2008. 
HOFFMANN, Helmut. "Exemplos da revitalização de áreas degradadas e contaminadas na Alemanha". In MOERI, Ernesto; COELHO, Rodrigo \& MARKER, Andreas (Eds). Remediação e revitalização de áreas contaminadas: aspectos técnicos, legais e financeiros. São Paulo. São Paulo: Signus Editora, 200e.

HOLLANDER, Justin B.; KIRKWOOD, Niall G. and GOLD, Julia L. Principles of Brownfield regeneration: clean up, design and reuse of derelict land. Washington DC, 2010.

HULA, Richard C. "Changing agendas in state environmental policy: development versus cleanup in brownfield programas". In HULA, Richard C., REESE, Laura A. \& JACKSON-Elmoore, Cynthia (editors), Reclaiming brownfields: a comparative analysis of adaptive reuse of contaminated properties. Farhan/Burlington: Ashgate, 2012.

JUSTIÇA libera construção de parque na represa de Guarapiranga, em SP. Folha de São Paulo, São Paulo, 03 nov. 2010. Disponível em: $<$ http://www1.folha.uol.com.br/cotidiano/825013-justica-libera-construcao-de-parquena-represa-de-guarapiranga-em-sp.shtml>. Acesso em: 21 out. 2011.

KÁTIA Abreu: reserva legal atrapalha atividade econômica. O Estado de São Paulo, São Paulo, 07 dez. 2010.2 Disponível em: $<$ http://www.estadao.com.br/noticias/impresso,reserva-legal-e-inutil-diz _ _ diz senadora, 650466,0.html>. Acesso em: 15 mar. 2011.

.KIRCHHOLTES, Hermann J. Brownfield revitalization step-by-step - framework in Stuttgart. In: SHORT COURSE "BROWNFIELD REVITALIZATION STEP BY STEP", São Paulo: Instituto Ekos Brasil/GTZ, 2004.

KIRCHHOLTES, Hermann J. Galvanic (Electroplating) Factory Stuttgart-Vaihingen (GTV). In: SHORT COURSE "BROWNFIELD REVITALIZATION STEP BY STEP", São Paulo: Instituto Ekos Brasil/GTZ, 2004.

KIRCHHOLTES, Hermann J. Brownfield revitalization "Fasanenhof Ost", StuttgartMöhringen. In: SHORT COURSE "BROWNFIELD REVITALIZATION STEP BY STEP", São Paulo: Instituto Ekos Brasil/GTZ, 2004.

LANGENBUCH, J.R. A estruturação da Grande São Paulo. Rio de Janeiro: Fundação IBGE, 1971. 
LAURENTINO, Fernando de Pádua. Várzeas do Tamanduateí: industrialização e desindustrialização. Dissertação de Mestrado. Faculdade de Filosofia, Letras e Ciências Humanas da Universidade de São Paulo. São Paulo, 2002.

LAYRARGUES, Philippe Pomier. A cortina de fumaça: o discurso empresarial verde e a ideologia da racionalidade econômica. São Paulo: Annablume, 1998.

LEFF, Enrique. Epistemologia ambiental. Tradução de Sandra Valenzuela. São Paulo: Cortez, 2007.

LEFF, Enrique. Ecologia, capital e cultura: A territorialização da racionalidade ambiental. Tradução da primeira edição de Jorge E. Silva. Petrópolis: Vozes, 2009.

LEITE, Maria Angela Faggin Pereira. Destruição ou reconstrução? Questões da paisagem e tendências de regionalização. São Paulo: Hucitec/FAPESP, 1994.

LEITE, Maria Angela Faggin Pereira. Natureza e cultura: paisagem, objetos e imagens. Paisagem e ambiente: ensaios. São Paulo: FAUUSP, n. 18, 2004.

LEITE, Maria Angela Faggin Pereira. "Uma história de movimentos". In: SANTOS, Milton e SILVEIRA, Maria Laura, O Brasil: território e sociedade no início do século $X X I$. Rio de Janeiro: Record, 2003, p.p. 433-445.

LOUREIRO, O movimento ambientalista e o pensamento crítico: uma abordagem política. Rio de Janeiro: Quartet, 2006.

LOWHAN, Elizabeth A. "Incentives for collaboration: state-level brownfield remediation and redevelopment programs". In HULA, Richard C., REESE, Laura A. \& JACKSON-Elmoore, Cynthia (editors), Reclaiming brownfields: a comparative analysis of adaptive reuse of contaminated properties. Farhan/Burlington: Ashgate, 2012.

MACEY, Greg P. "Introduction: the promises and pitfalls of adaptive site stewardship". In: MACEY, Gregg P. \& CANON, Jonathan Z. (editors), Reclaiming the land: rethinking Superfund institutions, methods and practices. New York: Springer Science, 2010.

MARCATTO, Flávia Silva. A participação pública na gestão de área contaminada: uma análise de caso baseada na Convenção de Aarhus. Dissertação de Mestrado. Faculdade de Saúde Pública da Universidade de São Paulo. São Paulo, 2005. 
MARTINS, Maria Lucia Refinetti. Moradia e mananciais: tensão e diálogo na metrópole. São Paulo: FAUUSP/FAPESP, 2006.

MCNEIL, Sue and LANGE, Deborah. "Engineering urban brownfield development: examples from Pittsburgh". In: In: KIRKWOOD, Niall (editor), Manufactured sites: rethinking the post-industrial landscape. New York: Taylor \& Francis, 2001.

MEYER, Regina Maria Prosperi; GROSTEIN, Marta Dora. A leste do centro: territórios do urbanismo. São Paulo: Imprensa Oficial do Estado de São Paulo, 2010. MONTIBELLER Filho, Gilberto. O mito do desenvolvimento sustentável: meio ambiente e custos sociais no moderno sistema produtor de mercadorias. Florianópolis: Editora da UFSC, 2004.

MORINAGA, Carlos Minoru. Recuperação de Áreas Contaminadas: um novo desafio para projetos paisagísticos. Dissertação de mestrado. Faculdade de Arquitetura e Urbanismo, Universidade de São Paulo, 2007.

MORINAGA, Carlos Minoru et al. "As potencialidades e limitações da aplicação de instrumentos urbanísticos de incentivo para a revitalização de áreas contaminadas na cidade de São Paulo". In: MOERI, Ernesto Niklaus; RODRIGUES, Delcio e NIETERS, Andreas, Áreas contaminadas: remediação e revitalização, volume 4, Instituto Ekos/GTZ, São Paulo, 2008.

PARLAMENTO EUROPEU \& CONSELHO DA UNIÃO EUROPEIA. Diretiva 2004/CE/35, de 21 de abril de 2004. Jornal Oficial da União Europeia, União Europeia, 30 de abril de 2004.

PORTO, Marcio. O processo de projeto e a sustentabilidade na produção da arquitetura. São Paulo: C4, 2009.

PRIME ENGENHARIA. Linha 2 Verde - Trecho Oratório - Cidade Tiradentes. Estudo de Impacto Ambiental. São Paulo, 2010.

RAMIRES, Jane Zilda dos Santos. Áreas contaminadas e os riscos socioambientais em São Paulo. Dissertação de Mestrado. Faculdade de Filosofia, Letras e Ciências Humanas da Universidade de São Paulo. São Paulo, 2008.

REGENERATION OF EUROPEAN SITES IN CITIES AND URBAN ENVIRONMENTS - RESCUE. Guidance on sustainable land use and urban design 
on brownfield sites - D 4.1. [publicação on line]. Disponível em <URL: http://www.rescue-europe.com/download/reports/4_Guidance > [2004].

ROGERS, Jean. "Industrial evolution: prevention of remediation through design". In: In: KIRKWOOD, Niall (editor), Manufactured sites: rethinking the post-industrial landscape. New York: Taylor \& Francis, 2001.

ROLNIK, Raquel. São Paulo / Raquel Rolnik. São Paulo: Publifolha, 2001.

ROSA, Márcia Alarcon et al. Educação ambiental na implantação de parques lineares. [Apresentado no Seminário Trilhas Urbanas - Parques Lineares: novas perspectivas para os rios da cidade, São Paulo, 2009]

SACHS, Ignacy. Ecodesenvolvimento: crescer sem destruir. São Paulo: Vértice, 1986.

SACHS, Ignacy. Caminhos para o desenvolvimento sustentável / organização: Paula Yone Stroh. Rio de Janeiro: Garamond, 2009.

SÁNCHEZ, Luís Enrique. Desengenharia: o passivo ambiental na desativação de empreendimentos industriais. São Paulo: EDUSP, 2001

SANTOS, Milton. Técnica, espaço, tempo: globalização e meio técnico-científico informacional. São Paulo: Hucitec, 1994.

SANTOS, Milton. Espaço \& método. São Paulo: Nobel, 1997.

SANTOS, Milton e SILVEIRA, Maria Laura. O Brasil: território e sociedade no início do século XXI. Rio de Janeiro: Record, 2003.

SÃO PAULO (Estado). Lei no 13.577, de 8 de julho de 2009. Dispõe sobre diretrizes e procedimentos para a proteção da qualidade do solo e gerenciamento de áreas contaminadas. Diário Oficial do Estado de São Paulo, Poder Executivo, São Paulo, SP, 9 de julho de 2009. Seção 1.

SÃO PAULO (Estado). Lei $n^{\circ}$ 12.300, de 16 de março de 2006. Institui a Política Estadual de Resíduos Sólidos e define princípios e diretrizes. Diário Oficial do Estado de São Paulo, Poder Executivo, São Paulo, SP, 17 de março de 2006. Seção 1. SÃO PAULO (Município), Prefeitura do Município de São Paulo, Secretaria do Verde e do Meio Ambiente, Núcleo de Gestão Descentralizada Centro-Oeste. A educação ambiental na implantação de parques lineares: relatos de práticas. São Paulo, 2009. 
SÃO PAULO (Município), Prefeitura do Município de São Paulo, Secretaria Municipal de Desenvolvimento Urbano. Operação Urbana Consorciada Mooca - Carioca: termo de referência para contratação de empresa ou consórcio de empresas para elaboração de estudos urbanísticos e estudos complementares de subsídio à formulação do projeto de lei da operação urbana consorciada. São Paulo, 2010.

SÃO PAULO (Município). Decreto no 51.436, de 26 de abril de 2010. Regulamenta a Lei $n^{\circ}$ 15.098, de 5 de janeiro de 2010, que obriga o Poder Executivo Municipal a publicar na Imprensa Oficial ou disponibilizar no site oficial da Prefeitura Relatório das Áreas Contaminadas do Município de São Paulo. Diário Oficial da Cidade, São Paulo, SP, 27 de abril de 2010.

SÃO PAULO (Município). Lei no 15.098, de 5 de janeiro de 2010. Obriga o Poder Executivo Municipal a publicar na Imprensa Oficial ou disponibilizar no site oficial da Prefeitura Relatório das Áreas Contaminadas do Município de São Paulo. Diário Oficial da Cidade, São Paulo, SP, 6 de janeiro de 2010.

SÃO PAULO (Município). Lei no 13.855, de 25 de agosto de 2004. Estabelece normas complementares ao Plano Diretor Estratégico, institui os Planos Regionais Estratégicos das Subprefeituras, dispõe sobre o parcelamento, disciplina e ordena o uso e ocupação do solo do Município de São Paulo. Diário Oficial da Cidade, São Paulo, SP, 6 de outubro de 2004.

SÃO PAULO (Município). Lei no 13.564, de 24 de abril de 2003. Dispõe sobre a aprovação de parcelamento de solo, edificação ou instalação de equipamentos em terrenos contaminados ou suspeitos de contaminação por materiais nocivos ao meio ambiente e à saúde pública, e dá outras providências. Diário Oficial da Cidade, São Paulo, SP, 25 de abril de 2003.

SÃO PAULO (Município). Lei no 13.430, de 13 de setembro de 2002. Plano Diretor Estratégico. Diário Oficial do Município, São Paulo, SP, 14 de setembro de 2002.

SÃO PAULO (Município). Decreto no 42.319, de 21 de agosto de 2002. Dispõe sobre diretrizes e procedimentos relativos ao gerenciamento de áreas contaminadas no Município de São Paulo. Diário Oficial da Cidade, São Paulo, SP, 22 de agosto de 2002.

SARNI, William. Greening brownfields: remediation through sustainable development. The McGraw-Hill Companies, 2010. 
SEABRA, Odete Carvalho de Lima. Os meandros dos rios nos meandros do poder: Tietê e Pinheiros - valorização dos rios e das várzeas na cidade de São Paulo. Tese de doutorado. Departamento de Geografia, Faculdade de Filosofia, Letras e Ciências Humanas, Universidade de São Paulo, 1987.

SERRA, Geraldo Gomes. Pesquisa em arquitetura e urbanismo: guia prático para o trabalho de pesquisadores em pós-graduação. São Paulo: EDUSP, 2006.

SILVA-SÁNCHEZ, Solange; MANETTI, Cláudio. Experiência de reconversão urbana e ambiental da bacia do córrego Água Podre. Parque Linear Água Podre. In: SEMINÁRIO NACIONAL SOBRE O TRATAMENTO DE ÁREAS DE PRESERVAÇÃO PERMANENTE EM MEIO URBANO E RESTRIÇÕES AMBIENTAIS AO PARCELAMENTO DO SOLO, 2007, São Paulo. Anais. FAUUSP, 2007. 1 CD.

SPINOLA, Ana Luiza Silva. Inserção das áreas contaminadas na gestão municipal: desafios e tendências. Tese de doutorado. Faculdade de Saúde Pública da Universidade de São Paulo. São Paulo. 2011.

SPÓSITO, Maria Encarnação Beltrão. "Os embates entre as questões ambientais e sociais no urbano". In CARLOS, Ana Fani Alessandri e LEMOS, Amália Inês Geraiges (orgs.), Dilemas urbanos: Novas abordagens sobre a cidade, São Paulo: Contexto, 2003.

SUGAI, Geni. Requalificação de antigas áreas industriais: novos significados para o bairro da Mooca. Tese de doutorado. Faculdade de Arquitetura e Urbanismo da Universidade de São Paulo. São Paulo. 2006.

TAKAHASHI, F. \& GERAQUE, E. Governo paulista expande USP Leste em área contaminada. Folha de São Paulo, São Paulo, 17 abr. 2012. Cotidiano, p. C7.

TEIXEIRA, Elenaldo Celso. O local e o global: limites e desafios da participação cidadã. São Paulo: Cortez; Recife: EQUIP; Salvador: UFBA. 2001.

UNITED STATES ENVIRONMENTAL PROTECTION AGENCY. Superfund Community Involvement Handbook. [publicação on line]. Disponível em <URL: http://www.epa.gov/ superfund/community/cag/pdfs/ci_handbook.pdf > [2005].

VACCARO, Ismael. "Theorizing Impending Peripheries: postindustrial landscapes at the edge of hyper-modernity's". In Journal of International and Global Studies, 2006. 
VALENTIM, Luís Sérgio Ozório. Sobre a produção de bens e males nas cidades. Estrutura urbana e cenários de risco à saúde em áreas contaminadas da Região Metropolitana de São Paulo. Tese de doutorado. Faculdade de Arquitetura e Urbanismo da Universidade de São Paulo. São Paulo, 2010.

VASCONCELOS, Eduardo Mourão. Complexidade e pesquisa interdisciplinar: epistemologia e metodologia operativa. Petrópolis: Vozes, 2002.

VASQUES, Amanda Ramalho. Geotecnologias nos estudos sobre brownfields: identificação de brownfields em imagens de alta resolução espacial e análise da dinâmica de refuncionalização de antigas áreas fabris em São Paulo. Tese de doutorado. Faculdade de Filosofia, Letras e Ciências Humanas da Universidade de São Paulo. São Paulo, 2009.

VEIGA, José Eli da. Meio ambiente \& desenvolvimento. São Paulo: Editora Senac São Paulo, 2006.

VEIGA, José Eli da. A emergência socioambiental. São Paulo: Editora Senac São Paulo, 2007.

VEIGA, José Eli da. Sustentabilidade: A legitimação de um novo valor. São Paulo: Editora Senac São Paulo, 2010. 